UNIVERSIDADE DE SÃO PAULO

ESCOLA DE ENGENHARIA DE SÃO CARLOS

DEPARTAMENTO DE GEOTECNIA

LIGIA DE FREITAS SAMPAIO

\title{
Estudo Geológico-Geotécnico dos Processos Erosivos e Proposta de Macrodrenagem: Voçoroca do Córrego do Cravo (Nazareno-MG)
}

\author{
Versão corrigida \\ Original se encontra disponível na Unidade que aloja o Programa.
}

São Carlos, SP

2014 


\section{Estudo Geológico-Geotécnico dos Processos Erosivos e Proposta de Macrodrenagem: Voçoroca do Córrego do Cravo (Nazareno-MG)}

Dissertação apresentada à Escola de Engenharia de São Carlos da Universidade de São Paulo, como parte dos requisitos para a obtenção do título de Mestre em Ciências, Programa de Pós-Graduação em Geotecnia.

Orientadora: Prof ${ }^{a}$. Dr ${ }^{\mathrm{a}}$. Valéria Guimarães Silvestre Rodrigues 
AUTORIZO A REPRODUÇÃO TOTAL OU PARCIAL DESTE TRABALHO, POR QUALQUER MEIO COONVENCIONAL OU ELETRÔNICO, PARA FINS DE ESTUDO E PESQUISA, DESDE QUE CITADA A FONTE.

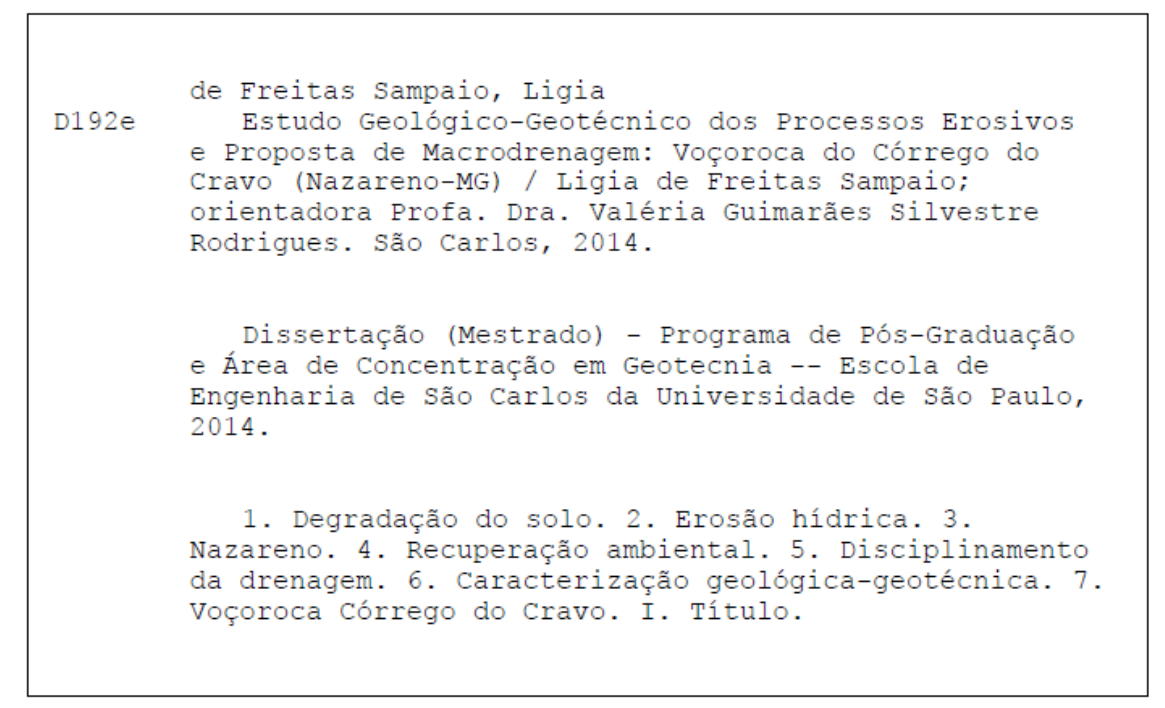




\section{FOLHA DE JULGAMENTO}

Candidata: Engenheira LIGIA DE FREITAS SAMPAIO.

Título da dissertação: "Estudo geológico-geotécnico dos processos erosivos e proposta de macrodrenagem: Voçoroca do Córrego do Cravo (Nazareno$M G) "$.

Data da defesa: 19/05/2014

Comissão Julgadora:

Profa. Dra. Valéria Guimarães Silvestre Rodrigues

(Orientadora)

(Escola de Engenharia de São Carlos/EESC)

Prof. Titular Orencio Monje Vilar

(Escola de Engenharia de São Carlos/EESC)

Dr. Rogério Resende Martins Ferreira

(Pesquisador - Institufo de Voçoroca)
Resultado:

APROUALA

APROVADA

Coordenador do Programa de Pós-Graduação em Geotecnia:

Prof. Titular Osni José Pejon

Presidente da Comissão de Pós-Graduação:

Prof. Titular Denis Vinicius Coury 
Dedico este trabalho ao pessoal de Nazareno, em Minas Gerais, e a todos aqueles que hoje sofrem com os problemas ambientais causados pelas gerações passadas; dedico também ao pessoal do Projeto Maria de Barro e a todos aqueles que se esforçam em deixar uma vida e ambiente melhor para as gerações futuras. 


\section{Agradecimentos}

Agradeço à professora Valéria, pela excelente orientação e apoio, pela amizade cultivada com muita dedicação nesses últimos anos, e por acreditar em meu potencial e trabalho.

Agradeço à Maria Paula pela grande amizade iniciada na graduação, com tantos momentos de crescimento e descobertas, pela energia e exemplo de superação que sempre trouxe inspiração para todos a seu redor, e por ser uma pessoa muito querida e especial, que me ensinou (e ainda ensina!) a viver.

Agradeço ao professor Osni pela paciência, pelo trabalho em equipe e por tanto aprendizado em tão pouco tempo.

Agradeço ao professor Joel pelos ensinamentos, apoio e simpatia, fundamentais no decorrer desta pesquisa e que levarei para a vida toda.

Agradeço ao professor Lázaro pelos conselhos e direções, e por tantas histórias que nos proporcionam os momentos de sabedoria de cada dia. Ao professor Orencio pelo auxílio e experiência trocados, e pela disponibilidade em nos ajudar prontamente.

Agradeço ao Vinicius, ao pessoal do Projeto Maria de Barro e de Nazareno, por abrirem as portas e nos receberem com tanto carinho e apoio.

Agradeço à CPRM, à FEAM, ao IGA, à Ivana M. F. Horta, ao Marcos G. C. A. Silva (CEMIG), ao Paulo Ernani, ao professor Marinho G. Andrade (ICMC), ao professor Rodrigo de Melo Porto (SHS) e a todos aqueles que prontamente se disponibilizaram para auxiliar a nossa pesquisa.

Agradeço aos técnicos dos laboratórios da Geotecnia, seu Antônio, Zé e Oscar, ao

pessoal da Secretaria, Álvaro, Neiva e Maristela, ao Herivelto, e ao pessoal dos laboratórios do IFSC e do IQSC, pelo auxílio, dedicação e paciência.

Agradeço à Coordenação de Aperfeiçoamento de Pessoal de Nível Superior (CAPES), pelo financiamento da bolsa de estudo.

Agradeço aos amigos do Departamento de Geotecnia e ao pessoal do Mapeamento, pelos momentos de descontração, amizade e consultorias rápidas e salvadoras, em especial à 
Camila (Lete) Almeida e à Danielle Bressiani (SHS), que foram imprescindíveis para o amadurecimento do trabalho e para renovar as energias.

Agradeço ao Filipe Gimenes, colega de graduação, pelo apoio e auxílio iniciais que me ensinaram a humildade e ajudaram a impulsionar essa pesquisa, ao Raul Cassaro, aluno da engenharia ambiental, pela ajuda e colaboração, e por sua sinceridade e energia contagiantes, às companheiras de orientação Isa e Mari, e à Claudinha, pelos momentos e crescimentos compartilhados, amizade, alegria e força para enfrentarmos todos os dias de trabalho.

Agradeço à minha querida família, Valdomiro, Sônia, Rafael, Carolina e Thaís, por todo o amor e companheirismo, pelo apoio em todos os momentos e decisões. Palavras não são o bastante para agradecer essa família linda e unida, que mesmo na distância, estiveram sempre presentes em meu coração. Agradeço também aos avós, Zé e Mariana, Neno e Maria, todos os tios e tias, primos e primas, cunhado, enfim, a toda essa família maravilhosa que agradeço a Deus por ter me escolhido e acolhido, amo todos vocês! Agradeço à família que encontrei em São Carlos, San, Joyce, Chien Ling(da) e Yao Hsing, pela sabedoria e amor e por me acolherem com tanto carinho e dedicação; vocês foram (e são) imprescindíveis em minha vida.

Agradeço a mais famílias lindas que foram criadas em São Carlos: à Tapinha e às Justicieras queridas, que cada ano crescem mais em tamanho e amor, e que também (foram e) são imprescindíveis para me completarem como pessoa. À Lu, Nina, Leza, Lê (e Clarinha!), Jú, Elisa, Amorinha, Bebete, Princess, Fanta, Mingau, Neyla, Débs, Boo, Baiana, Tieta, bixetes novinhas, Cássinha, Aninha (Q3+1 4ever!), Danie, Gabi, Mari(iiiiii)a, Mangá, Amanda, Char, Munique, Ingrid, enfim, minas...amo vocês. Não posso esquecer de agradecer às quiancinhas de nossas vidas, Homer, Kika, Lóli e Sol, que não importa o que aconteça, sempre estão muito felizes em nos ver.

Agradeço ao Isma, por toda parceria, paciência e carinho, e por fazer o sol brilhar mais claro e alegre, sempre...à Poli, por suas histórias e apoio, nossas conversas sem fim...ao Levi, amigo e professor, pelos momentos de inspiração e arte...ao pessoal do CAASO e do Grupo de Som, pela amizade e crescimento, compartilhamento de experiências e por me ensinarem a arte da paciência...às amigas de Ribeirão Preto, Ju, Sá, Carol, Angélica, Mari, Ana Carolinne, Silvinha, Laíza, que mesmo cada uma seguindo seu caminho, sempre estiveram em meu coração, e a todos aqueles que passaram e marcaram minha vida nesses últimos anos. 


\section{Resumo}

SAMPAIO, L. F. Estudo Geológico-Geotécnico dos Processos Erosivos e Proposta de Macrodrenagem: Voçoroca do Córrego do Cravo (Nazareno-MG). 2014. 223p. Dissertação (Mestrado) - Escola de Engenharia de São Carlos, Universidade de São Paulo, São Carlos. 2014.

A dinâmica dos sistemas naturais se constrói na integração de todos os elementos pertencentes ao ambiente. Caso o conhecimento do meio físico e da influência das atividades antrópicas nesta dinâmica não sejam considerados em conjunto com o uso e ocupação, problemas ambientais de difícil recuperação, como as voçorocas, podem ser gerados, prejudicando a própria manutenção e expansão das atividades humanas. Neste sentido, o objetivo desta pesquisa foi avaliar de forma integrada os condicionantes geológicos e geotécnicos e as propriedades que interferem na drenagem da água superficial e subsuperficial em uma voçoroca do município de Nazareno, no estado de Minas Gerais (voçoroca do Córrego do Cravo). Diante disso, foram elaborados mapas com a utilização de $S I G$ para levantamento e análise das características da bacia do Córrego do Cravo e da bacia de contribuição da voçoroca. Ensaios em laboratório (permeabilidade, erodibilidade, parâmetros físico-químicos, matéria orgânica, MCT e MEV/EDS) foram realizados para caracterização geológica e geotécnica, assim como o tratamento de dados pluviométricos e o programa $A B C$ 6, para estudo do comportamento e da vazão das chuvas. Por fim, para avaliação das propostas de macrodrenagem na bacia de contribuição da voçoroca do Córrego do Cravo, utilizou-se o programa Canal. Os resultados apontaram que, nesta região, as elevadas declividades e susceptibilidade do solo saprolítico (Cambissolo) são os principais condicionantes do ambiente, sendo a intensidade das chuvas, as direções do fluxo superficial, sua concentração (originada pela retirada da cobertura vegetal e manejo inadequado do solo tanto pelas atividades agropecuárias como pela implantação de obras de infraestrutura, como estradas, por exemplo), e a exposição do nível d'água subterrâneo no interior da voçoroca, os principais fatores que proporcionam o desenvolvimento e retorno dos processos erosivos. Dessa forma, a redução do volume e da energia do escoamento superficial em direção ao solo saprolítico, concomitante ao recolhimento e disciplinamento da água subsuperficial no interior da voçoroca, são consideradas imprescindíveis à estabilização dos processos erosivos. As propostas de macrodrenagem, de maneira geral, poderão ser aplicadas, não somente na voçoroca do Córrego do Cravo, mas também em outras voçorocas de Nazareno com propriedades geológicas-geotécnicas similares.

Palavras-chave: Degradação do Solo, Erosão Hídrica, Nazareno, Recuperação Ambiental, Drenagem e Infiltração. 


\begin{abstract}
SAMPAIO, L. F. Geological and Geotechnical Study of Erosive Processes and Proposition of a Macro-drainage System: Córrego do Cravo Gully (Nazareno-MG, Brazil). 2014. 223p. Thesis (Masters in Geotechnical Engineering) - Escola de Engenharia de São Carlos, Universidade de São Paulo. São Carlos. 2014.

The dynamics of natural systems are based on the integration of all environmental elements. If the knowledge of physical conditions and of the influence of anthropogenic activities are not considered jointly with land use difficult environmental problems, as gullies, are generated and may cause damages both on maintenance and on expansion of human activities. Thus, this research aims to evaluate the geological and geotechnical constraints and properties which interfere in the superficial and subsuperficial drainage systems of a gully in the Nazareno municipality, at Minas Gerais state, Brazil (Córrego do Cravo gully). Therefore, maps to survey data from the Córrego do Cravo basin and the gully contribution area were made, using GIS tools. In addition, laboratory tests (permeability, erodibility, physicalchemical parameters, organic matter, MCT and SEM/EDS) were conducted for a geological and geotechnical characterization, as well as a study of the precipitation data was done and the software $A B C 6$ was used to evaluate rainfall and flow. Finally, for the macro drainage system assessment the software Canal was used. The results showed that the steep slopes and the saprolite soil susceptibility (Cambisol) are the main environmental constraints, and the rainfall intensity, the flow directions and its concentration (that is generated by the removal of vegetation and inadequate land use, both urban and agricultural), and the exposure of the water table level in the gully are the main factors that developed and brought the erosive processes back. Hence, both flow volume and energy towards the saprolite soil, in addition with subsuperficial water collection and its discipline inside the gully, are considered indispensable to stabilize of the erosive processes. The macro drainage system proposition can be applied in other gullie areas with similar geological and geotechnical properties.
\end{abstract}

Keywords: Soil Degradation, Water Erosion, Nazareno, Environmental Recovery, Drainage and Seepage. 


\section{Lista de Figuras}

Figura 1 Geometria e declividades em encostas retilínea, convexa e côncava. (RODRIGUES, 1982 apud SILVA; SCHULZ; CAMARGO, 2004).

Figura 2 - Voçoroca com erosão subsuperficial (Adaptada de ZACHAR, 1982).....

Figura 3 - Erosão por escoamento laminar e por escoamento concentrado, formando sulcos na superfície do terreno. (DAEE/IPT, 1989)......

Figura 4 - Sulcos e ravinas causados por trilhas de gado em morros, na região do Médio Rio Grande (MG). (MAGRI, 2013)..

Figura 5 - Morfologia de sulcos, ravinas e boçorocas (KARMANN, 2000 apud PONS, 2006). .40

Figura 6 - Formação e desenvolvimento das voçorocas. (Modificada de FENDRICH, 1997 e ZACHAR, 1982)

Figura 7 - Principais passos na tomada de decisão em um processo típico de gestão ambiental (Modificada de MATTHEWS et al., 1976 apud BARROW, 2006)...

Figura 8 - Sarjeta em depressão rasa. (Modificada de MICHELIN, 1975)...... . .59

Figura 9 - Rápido. (Modificada de MICHELIN, 1975). 59

Figura 10 - Bacia de dissipação tipo mergulho em perfil. (PONTES, 1980 apud DANTAS, 2008). .59

Figura 11 - Características físicas e geométricas de seção transversal de rodovia (Modificada de DNER, 1996)

Figura 12 - Zonas da água na litosfera. (Adaptada de SEN, 1995) .........................................................62

Figura 13 - Quantidade total de água infiltrada em relação ao tempo (WILKEN, 1978).

Figura 14 - Esquema mostrando algumas obras/medidas necessárias para contenção de uma voçoroca (EMBRAPA, 2011).

Figura 15 - Dreno de bambu, composto de brita e bambus amarrados em feixes, recobertos por material impermeável (selo). (EMBRAPA, 2011).....

Figura 16 - Dreno de geotêxtil, composto por manta geotêxtil preenchida por brita. (EMBRAPA, 2011).

Figura 17 - Localização e acesso à área de estudo (Nazareno) e de seus municípios limítrofes. .67

Figura 18 - Mapa geotectônico simplificado da América do Sul (Adaptada de TEIXEIRA; FIGUEIREDO, 1991).

Figura 19 - Forma de ocorrência de xistos ultramáficos semelhante à encontrada na área de estudo (TOLEDO, 2002).

Figura 20 - Contexto geológico próximo à área urbana de Nazareno/MG. (Modificada de SAMPAIO et al., 2014).

Figura 21 - Perfil de Latossolo Vermelho Distroférrico (LVdf) encontrado na área de estudo. (HORTA, 2006)..

Figura 22 - Perfil de Latossolo Vermelho-Amarelo distrófico (LVAd). (HORTA, 2006). .78 
Figura 23 - Perfil de Cambissolo Háplico Distrófico (Cxbd). (HORTA, 2006)

Figura 24 - Conformação do relevo próximo à área urbana de Nazareno/MG.

Figura 25 - Erosividade anual das chuvas no estado de Minas Gerais (MJ.mm.ha ${ }^{-1}$ ); em amarelo a localização aproximada de Nazareno (Adaptada de MELLO et al., 2007).

Figura 26 - Precipitação anual $(\mathrm{mm})$ no estado de Minas Gerais; em amarelo a localização aproximada de Nazareno (Adaptada de MELLO et al., 2007).

Figura 27 - Região próxima à cidade de Nazareno. Ortofotocarta da CEMIG, de 1985, em escala 1:10.000 à esquerda; imagem de 2007, à direita. As setas amarelas indicam a voçoroca do Córrego do Cravo, e as linhas pontilhadas amarelas indicam a expansão urbana e da cultura entre esses anos, para a região próxima a essa voçoroca.

Figura 28 - Vista geral da voçoroca do Córrego do Cravo em 2010, durante atividades de recuperação. Imagem cedida pelo Projeto Maria de Barro.

Figura 29 - Coveamento na voçoroca do Córrego do Cravo, em 2010. Imagem cedida pelo Projeto Maria de Barro.

Figura 30 - A) Vista da voçoroca do Córrego do Cravo com o escorregamento translacional (1) e rotacional (2), em julho de 2012 (OLIVEIRA, no prelo); B) Vista de parte da voçoroca do Córrego do Cravo em setembro de 2012, com destaque para o deslizamento translacional à frente.

Figura 31 - Vista de cima da voçoroca do Córrego do Cravo (montante), com a cidade de Nazareno ao fundo (julho de 2013).

Figura 32 - Vista da parte interna da voçoroca do Córrego do Cravo (julho de 2013).....

Figura 33 - Medição da profundidade de um braço da voçoroca do Córrego do Cravo, em Nazareno/MG.

Figura 34 - Contato entre o Latossolo (porção superior) e o Saprolito (porção inferior, mais clara) - Voçoroca do Córrego do Cravo.

Figura 35 - Variabilidade das características do solo. A) Solo mais quartzoso (aspecto sacaroidal), B) Solo mais claro (pouco coeso) e C) Solo com xistosidade (material mais escuro)

Figura 36 - Piping localizado no solo com aspecto quartzoso (sacaroidal) (Figura 35A) 101

Figura 37 - A) Amostra indeformada empregada no ensaio de permeabilidade (PVC de $9 \mathrm{~cm}$ de altura); B) Amostra indeformada retirada para o ensaio de erodibilidade ( $\mathrm{PVC}$ de $2 \mathrm{~cm}$ de altura).....

Figura 38 - Trincheira de $80 \mathrm{~cm}$ aberta em solo laterítico, próxima ao cafezal, coleta de amostras indeformadas e deformadas.

Figura 39 - Código de direção de fluxo, retirado do $\operatorname{Arc} G I S^{\circledR}$.

Figura 40 - Carga constante mantida com reservatório grande (Adaptado de DANIEL, 1994), à esquerda; ensaio de condutividade hidráulica a carga constante, à direita.

Figura 41 - Preparação dos anéis para ensaio de erodibilidade.

Figura 42 - Equipamento usado na saturação da amostra; detalhe da pedra porosa.

Figura 43 - Imersão em água das amostras para medida do solo desprendido. 
Figura 44 - Amostras sendo agitadas para determinação do $\Delta \mathrm{pH}$ (esquerda); amostras em descanso (direita).

Figura 45 - a) pHmetro Digimed empregado na determinação do pH; b) phmetro Micronal empregado na determinação do Eh; c) Condutivímetro Analyser usado na determinação da CE.

Figura 46 - Aquecimento das amostras, ensaio de oxidação de matéria orgânica.

Figura 47 - Compactador de Mini MCV para o ensaio MCT, à esquerda, e tanque para ensaio de perda de massa por imersão, à direita.

Figura 48 - Estudo das áreas para encontrar o Número da Curva $(\mathrm{CN})$ na voçoroca do Córrego do Cravo, Nazareno/MG. 121

Figura 49 - Esquema da bacia do Córrego do Cravo, na interface do $A B C 6$ .122

Figura 50 - Considerações feitas para o cálculo do tempo de concentração utilizando a equação do método SCS.......

Figura 51 - Ietograma de precipitações utilizando as curvas $I D F$ de Barbacena/MG - $A B C 6$

Figura 52 - Curva $C N$ (infiltração no método $S C S$ ) - ABC 6.

Figura 53 - Ambiente para trabalho utilizando o software Canal (GPRH - Universidade Federal de Viçosa). .127

Figura 54 - Mapa de classes hipsométricas da bacia do Córrego do Cravo, Nazareno/MG .130

Figura 55 - Mapa de classes de declividade da bacia do Córrego do Cravo, Nazareno/MG. .131

Figura 56 - Mapa de direções de fluxo, da bacia do Córrego do Cravo, Nazareno/MG

Figura 57 - Escoamento direto da estrada para a voçoroca do Córrego do Cravo, Nazareno/MG.

Figura 58 - Uso e ocupação da bacia do Córrego do Cravo, Nazareno/MG 136

Figura 59 - Modelo de diagrama Eh-pH: o paralelogramo inscrito representa os limites usuais encontrados na superfície da crosta terrestre. O círculo apresenta a localização dos resultados para os solos da voçoroca do Córrego do Cravo em Nazareno/MG. Adaptado de Krauscopf (1972 apud Leite, 2001).

Figura 60 - Latossolo Vermelho, com concreções de argila laterítica (NOGAMI e VILLIBOR, 1995). 148

Figura 61 - Solo saprolítico de micaxisto, com quartzo e mica intemperizada (NOGAMI e VILLIBOR, 1995).

Figura 62 - Amostra de solo laterítico (LAT T3): A) Ampliação de 100 vezes; B) Ampliação de 1000 vezes; C) Ampliação de 3000 vezes...

Figura 63 - Espectros EDS da amostra LAT T3 (obtido em três áreas distintas).

Figura 64 - a) Latossolo Roxo (terra roxa), argiloso; b) Latossolo Vermelho-amarelo, argiloso. (Adaptado de NOGAMI e VILLIBOR, 1995).

Figura 65 - Abertura realizada em fissura em uma encosta da voçoroca do Córrego do Cravo, Nazareno/MG, no Latossolo.

Figura 66 - Amostra de solo saprolítico (SAP 1): A) Ampliação de 100 vezes; B) Ampliação de 1000 vezes, região de cima; C) Ampliação de 1000 vezes, região de baixo; D) Ampliação de 3000 vezes. 
Figura 67 - Espectros EDS da amostra SAP 1 (obtido em três áreas distintas)

Figura 68 - Amostra de solo saprolítico (SAP 2): A) Ampliação de 100 vezes; B) Ampliação de 1000 vezes; C) Ampliação de 3000 vezes..

Figura 69 - Espectros EDS da amostra SAP 2 (obtido em três áreas distintas)

Figura 70 - Amostra de solo saprolítico (SAP TX 3): A) Ampliação de 200 vezes; B) Ampliação de 1000 vezes;

C) Ampliação de 3000 vezes.

Figura 71 - Espectros EDS da amostra SAP TX 3 (obtido em três áreas distintas).....

Figura 72 - Afloramento de talco-xisto em solo saprolítico, voçoroca do Córrego do Cravo, Nazareno/MG.

Figura 73 - Amostra de solo saprolítico (SAP P 6): A) Ampliação de 100 vezes; B) Ampliação de 1000 vezes; C) Ampliação de 3000 vezes. 161

Figura 74 - Amostra de solo saprolítico (SAP P 7): A) Ampliação de 100 vezes; B) Ampliação de 1000 vezes; C) Ampliação de 3000 vezes.

Figura 75 - Amostra de solo saprolítico (SAP P 8): A) Ampliação de 200 vezes; B) Ampliação de 1000 vezes; C) Ampliação de 3000 vezes.

Figura 76 - Solo saprolítico de filito, com macrocristais de sericita (Adaptada de NOGAMI e VILLIBOR, 1995).

Figura 77 - Solo saprolítico de micaxisto, com macrocristais de caulinita (Adaptada de NOGAMI e VILLIBOR, 1995).

Figura 78 - Espectros EDS da amostra SAP P 6.

Figura 79 - Espectros EDS da amostra SAP P 7 164

Figura 80 - Espectros EDS da amostra SAP P 8.

Figura 81 - Hidrogramas para Barbacena/MG, com período de retorno de 10 anos e duração de 30 minutos de chuva $-A B C 6$

Figura 82 - Precipitação para Barbacena/MG, com período de retorno de 10 anos e duração de 30 minutos de chuva $-A B C 6$

Figura 83 - Hidrograma encontrado para o nó 2 (exutório) da bacia de contribuição - $A B C 6$. 170

Figura 84 - Concepção de proposta de drenagem para a bacia de contribuição da voçoroca do Córrego do Cravo, Nazareno/MG.

Figura 85 - Estrada de terra margeando o cafezal próximo à voçoroca do Córrego do Cravo, em Nazareno/MG

Figura 86- Detalhe do limite entre a estrada de terra do cafezal e a voçoroca do Córrego do Cravo, em Nazareno/MG.

Figura 87 - Trincheira de infiltração com escoamento direto (Modificada de BAPTISTA; NASCIMENTO; BARRAUD, 2011).

Figura 88 - Esquema de uma trincheira em declive dotada de divisórias (AZZOUT et al., 1994 apud BAPTISTA; ALMEIDA; BARRAUD, 2011). 
Figura 89 - Exemplo de proteção da trincheira: cesto para retirada de material (Modificada de AZZOUT et al., 1994 apud BAPTISTA; ALMEIDA; BARRAUD, 2011).

Figura 90 - Superfície de infiltração a ser considerada na determinação da vazão de saída no caso de uma trincheira (AZZOUT et al., 1994 apud BAPTISTA; ALMEIDA; BARRAUD, 2011). .180

Figura 91 - Canal circular com declividade de $0,1000 \mathrm{~m} \cdot \mathrm{m}^{-1}$ 181

Figura 92 - Canal circular com declividade de $0,2000 \mathrm{~m} \mathrm{~m}^{-1}$ 182

Figura 93 - Canal circular com diâmetro de 5,00 m 184

Figura 94 - Canal trapezoidal com declividade de $0,1000 \mathrm{~m} \cdot \mathrm{m}^{-1}$ 185

Figura 95 - Canal trapezoidal com declividade de $0,2000 \mathrm{~m} \cdot \mathrm{m}^{-1}$ 185

Figura 96 - Canal trapezoidal com coeficiente de rugosidade de 0,0200. 186

Figura 97 - Canal trapezoidal com coeficiente de rugosidade de 0,0230. 187

Figura 98 - Canal trapezoidal com coeficiente de rugosidade de 0,0300. 188

Figura 99 - Canal trapezoidal com coeficiente de rugosidade de 0,0300 e declividade de 0,1000 m.m ${ }^{-1}$ 189

Figura 100 - Canal trapezoidal com coeficiente de rugosidade de 0,0300 e declividade de 0,2000 m.m ${ }^{-1} \ldots \ldots . .189$

Figura 101 - Distância corrigida por uma barragem de consolidação. (DURLO E SUTILI, 2005). 191

Figura 102 - Soleiras do tipo inclinada (esquerda) e sinoidal (direita). Modificada de Durlo e Sutili (2005).

Figura 103 - Barragem de consolidação construída em madeira e pedras. Modificada de Durlo e Sutili (2005) 192

Figura 104 - Ressalto hidráulico (PORTO, 2006) .193

Figura 105 - Terraço em base estreita (DAEE/IPT, 1989) 193

Figura 106 - Afloramento de nível d’água subterrâneo na voçoroca do Córrego do Cravo, em Nazareno/MG... .194

Figura 107- Canais internos formados pelo afloramento do nível d'água subterrâneo na voçoroca do Córrego do Cravo, Nazareno/MG...... 194

Figura 108 - Área alagada no interior da voçoroca do Córrego do Cravo, Nazareno/MG. 195

Figura 109 - Pipings e sumidouros observados desde os topos de braços da voçoroca do Córrego do Cravo, Nazareno/MG...... .195

Figura 110 - Pipings na base, pequenos escorregamentos e sulcos na encosta em um dos braços da voçoroca do Córrego do Cravo, Nazareno/MG. 196

Figura 111 - Sulcos e escorregamentos de médio porte em encosta de um dos braços da voçoroca do Córrego do Cravo em Nazareno/MG. Possível verificar na extrema esquerda uma fissura apontando possibilidade de escorregamento futuro. 196

Figura 112 - Sucessão de vegetação no interior da voçoroca do Córrego do Cravo em Nazareno/MG .197

Figura 113 - Transformação de um canal reto com um sistema corrente-reservatório em um canal meandrante (Modificada de KELLER, 1972 apud KNIGHTON, 1998). .198 
Figura 114 - Feixe vivo adaptado de Durlo e Sutili (2005).

Figura 115 - Feixe (cilindro vivo) adaptado de Durlo e Sutili (2005).

Figura 116 - Seção proposta para a drenagem interna da voçoroca do Córrego do Cravo, Nazareno/MG. 200

Figura 117 - Destinação dos drenos (seta em vermelho) da água subterrânea da voçoroca do Córrego do Cravo, em Nazareno/MG. Seta em azul, drenagem natural receptora.

Figura 118 - Área proposta para o término da drenagem no final da base da voçoroca do Córrego do Cravo, em Nazareno/MG 201

Figura 119 - Estrada de terra limítrofe à lateral da voçoroca do Córrego do Cravo, Nazareno/MG. .203 


\section{Lista de Gráficos}

Gráfico 1 - Precipitações média e máxima mensal no eixo à esquerda, e precipitação total no mês no eixo à direita, para o ano de 1985. (UHE Itutinga - CEMIG)

Gráfico 2 - Precipitações média e máxima mensal no eixo à esquerda, e precipitação total no mês no eixo à

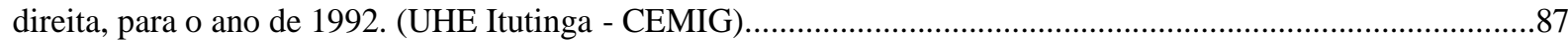

Gráfico 3 - Precipitações média e máxima mensal no eixo à esquerda, e precipitação total no mês no eixo à direita, para o ano de 2010. (UHE Itutinga - CEMIG).

Gráfico 4 - Precipitações média e máxima mensal no eixo à esquerda, e precipitação total no mês no eixo à direita, para o ano de 2011. A marcação em vermelho indica os meses nos quais faltam dados (UHE Itutinga CEMIG).

Gráfico 5 - Precipitações média e máxima mensal no eixo à esquerda, e precipitação total no mês no eixo à direita, para o ano de 2012. A marcação em vermelho indica os meses nos quais faltam dados (UHE Itutinga CEMIG).

Gráfico 6 - Precipitações média e máxima mensal no eixo à esquerda, e precipitação total no mês no eixo à direita, para o ano de 2013. A marcação em vermelho indica os meses nos quais faltam dados (UHE Itutinga CEMIG)

Gráfico 7 - Resultado do ensaio de erodibilidade com diferentes tipos de solos da voçoroca do Córrego do Cravo, Nazareno/MG

Gráfico 8 - Eh - pH: solos da voçoroca do Córrego do Cravo, Nazareno/MG .143

Gráfico 9 - Classificação MCT da amostra de Latossolo LAT 1, Nazareno/MG 147

Gráfico 10 - Classificação MCT da amostra de solo saprolítico SAP P 7, Nazareno/MG 149

Gráfico 11 - Precipitações médias e máximas mensais (1973 a 2012) - Estação Bom Sucesso/MG. 167 


\section{Lista de Tabelas}

Tabela 1 - As grandes questões relacionadas à erosão (Adaptado de BOARDMAN, 2006).

Tabela 2 - Período de retorno para diferentes ocupações da área. (PORTO, 1995 apud SILVEIRA, 2010).

Tabela 3 - Os quatro grupos hidrológicos de solo do SCS (Adaptada de PORTO, 1995)..... .56

Tabela $4-C N$ de escoamentos superficiais para coberturas complexas dos tipos hidrológicos do solo sob condições médias de antecedentes de umidade (Adaptada de SCS, 1972 apud STONE; RENARD; LANE, 1996).

Tabela 5 - Principais características de três eventos de deformações metamórficas reconhecidos na região de São João Del Rei - Nazareno. (Adaptado de TEIXEIRA; ÁVILA; NUNES, 2008). 70

Tabela 6 - Composição geoquímica das unidades geológicas magmática-metamórficas de ocorrência da região de Lavras, MG. Quéméneur (1995 apud LACERDA et al., 2009).

Tabela 7 - Características físico-químicas de Latossolo Vermelho distrófico da voçoroca do Córrego do Cravo (Nazareno/MG). Adaptado de Ferreira (2005).

Tabela 8 - Relação entre superfícies de erosão, marcos geográficos, altitudes, principais rochas de origem e solos predominantes da região de Lavras - MG. Adaptado de CURI et al. (1990 apud SILVA, 1990).

Tabela 9 - Modelo geomorfológico-pedológico da região de Lavras. (ANDRADE et al., 1998 apud LACERDA et al., 2009)

Tabela 10 - Dados referentes ao caminhamento realizado na voçoroca do Córrego do Cravo. .98 e 99

Tabela 11 - Detalhamento dos pontos de coleta - Voçoroca do Córrego do Cravo Nazareno/MG 103 e 104

Tabela 12- Dados das estações pluviométricas.

Tabela 13 - Dados de entrada para o cálculo da bacia realizado no programa $A B C$

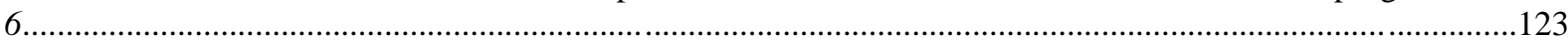

Tabela 14 - Relação das áreas encontradas para cada intervalo de classe hipsométrica na bacia do Córrego do Cravo, Nazareno/MG

Tabela 15 - Relação das áreas encontradas para as classes de declividade na bacia do Córrego do Cravo, Nazareno/MG

Tabela 16 - Relação das áreas encontradas para as direções de fluxo na bacia do Córrego do Cravo, Nazareno/MG.

Tabela 17 - Resultados do ensaio de $\Delta \mathrm{pH}\left(\mathrm{pH}_{\mathrm{KCl}}\right.$ e $\left.\mathrm{pH}_{\mathrm{H} 2 \mathrm{O}}\right)$, $\mathrm{CE}$ e Eh.

Tabela 18 - Resultados do ensaio de oxidação da matéria orgânica no solo.

Tabela 19 - Classificação MCT e dados diversos dos grupos de solos integrantes da mesma (Modificada de NOGAMI e VILLIBOR, 1995).

Tabela 20 - Análise granulométrica conjunto e massa específica dos sólidos de amostra de solo laterítico LAT 1 - voçoroca do Córrego do Cravo, Nazareno/MG. 
Tabela 21 - Análise granulométrica conjunto e massa específica dos sólidos de amostras de solo laterítico e saprolítico - voçoroca do Córrego do Cravo, Nazareno/MG.

Tabela 22 - Média dos elementos obtida a partir dos EDS - LAT T3 (Figura 63).

Tabela 23 - Média dos elementos obtida a partir dos EDS - SAP 1 (Figura 67)

Tabela 24 - Média dos elementos obtida a partir dos EDS - SAP 2 (Figura 69) .157

Tabela 25 - Média dos elementos obtida a partir dos EDS - SAP TX 3 (Figura 71)

Tabela 26 - Média dos elementos obtida a partir dos EDS - SAP P 6 .164

Tabela 27 - Média dos elementos obtida a partir dos EDS - SAP P 7

Tabela 28 - Média dos elementos obtida a partir dos EDS - SAP P 8 .165

Tabela 29 - Quesitos para análise da viabilidade de realização de trincheiras de infiltração utilizados de Baptista, Nascimento e Barraud (2011).

Tabela 30 - Capacidade de armazenamento em função da inclinação da trincheira para um volume geométrico $\mathrm{S}_{\mathrm{g}}=\mathrm{npLl}$ (Modificada de BAPTISTA; ALMEIDA; BARRAUD, 2011).

Tabela 31 - Valores do coeficiente de rugosidade da fórmula de Manning. (Adaptada de PORTO, 2006) 


\section{Lista de Siglas e Símbolos}

$\boldsymbol{A}$ Área da seção transversal - Lei de Darcy (Equação 13)

ABC Análise de Bacias Complexas

ABNT Associação Brasileira de Normas Técnicas

ANA Agência Nacional de Águas

b Largura da base (canal trapezoidal)

BP Bradley-Peterka (dissipador de energia)

c’ Argilosidade do solo

C Coeficiente de Chezy (Equação 9)

CE Condutividade Elétrica

CIVILNET Recursos da Engenharia Civil na Internet (site nacional)

CPRM Serviço Geológico do Brasil

CTC Capacidade de Troca Catiônica

DAEE Departamento de Águas e Energia Elétrica

DHP Drenos Horizontais Profundos

DNER Departamento Nacional de Estradas de Rodagem

$\boldsymbol{e}^{\prime} \quad$ Grau de Laterização

EESC Escola de Engenharia de São Carlos

EDS Espectroscopia de Energia Dispersiva

Eh Potencial de oxi-redução

EMBRAPA Empresa Brasileira de Pesquisa Agropecuária

$f \quad$ Folga (canal)

$\boldsymbol{F}_{\boldsymbol{i}} \quad$ Quantidade total de água infiltrada (Equação 12)

Fr Número de Froude

GPRHGrupo de Pesquisa em Recursos Hídricos

$\boldsymbol{H}_{\boldsymbol{m}} \quad$ Altura hidráulica (relação entre a área molhada e a largura da seção, Equação 11)

$\mathrm{H}_{2} \mathrm{O}_{2}$ Peróxido de hidrogênio

$\boldsymbol{i} \quad$ Intensidade da chuva máxima (Equação 1) 
i Gradiente hidráulico - Lei de Darcy (Equação 13)

$\boldsymbol{i}=1,2,3, . ., n$ Números de estações a serem utilizadas (Equações 18 a 22)

I Inclinação do canal (Equações 9 e 10)

$I_{a} \quad$ Abstração inicial (Equação 4)

IBGE Instituto Brasileiro de Geografia e Estatística

IDF Equação de Intensidade - Duração - Frequência de chuvas

IGAMInstituto Mineiro de Gestão das Águas

INMET Instituto Nacional de Meteorologia

INPE Instituto Nacional de Pesquisas Espaciais

IP Instituto de Pesquisas Tecnológicas

K Condutividade hidráulica - Lei de Darcy (Equação 13)

K Parâmetro da equação IDF (Equação 1)

$\mathbf{K C l}$ Cloreto de potássio

$\boldsymbol{L} \quad$ Comprimento do corpo de prova - Lei de Darcy (Equação 13)

LabSid Laboratório de Sistemas de Suporte a Decisões

LENHS Laboratório de Eficiência Energética e Hidráulica em Saneamento

m Parâmetro da equação IDF (Equação 1)

m Número de ordem da precipitação considerada (Equação 2)

MCT Miniatura, Compactada, Tropical

MD Modelo Digital de Elevação

MDT Modelo Digital de Terreno

MEV Microscopia Eletrônica de Varredura

Mini MCV Moisture, Condition, Value - Umidade, Condição, Valor

M.O. Matéria orgânica

$M_{S} \quad$ Massa de solo seco (Equação 17)

MS Munir Saab (dissipador de energia)

$M_{t} \quad$ Massa total de solo (Equação 17)

n Parâmetro da equação IDF(Equação 1)

n Ordem de magnitude decrescente (Equação 2) 
n Coeficiente de Manning (Equação 10)

$n \quad$ Total de estações utilizadas (Equações 18 a 22)

N.A. Nível d'água subterrâneo

NBR Normas Brasileiras

ONG Organização Não Governamental

pH Potencial Hidrogeniônico

pKCl Potencial de Cloreto de potássio

$\boldsymbol{P} \quad$ Probabilidade (Equação 3)

$\boldsymbol{P} \quad$ Precipitação (Equação 12)

$\boldsymbol{P} \quad$ Perda por imersão (Equações 14 e 15)

$\boldsymbol{q}$ Vazão - Lei de Darcy (Equação 13)

$\boldsymbol{Q}$ Escoamento superficial (Equação 4)

$\boldsymbol{Q}_{\boldsymbol{S}} \quad$ Escoamento superficial (Equação 12)

$\boldsymbol{r}_{x y} \quad$ Coeficiente de correlação (Equação 20)

$\boldsymbol{R} \quad$ Precipitação (Equação 4)

$\boldsymbol{R}_{\boldsymbol{h}} \quad$ Raio hidráulico (calculado pela relação entre a área da seção e o perímetro molhado, Equações 9 e 10)

$\boldsymbol{s}_{\boldsymbol{x}} \quad$ Desvio padrão (raiz quadrada da variância) (Equações 18, 20, 21 e 22)

$s_{x y} \quad$ Co-variância amostral

$\boldsymbol{S} \quad$ Perdas potenciais máximas que podem ocorrer após o início do escoamento, somadas à abstração inicial (Equação 4)

$S \quad$ índice de absorção de água (Equação 14 e 15)

SCS-CN Soil Conservation Service - Curve Number

$S_{e} \quad$ Detenção superficial total

SHS Departamento de Hidráulica e Saneamento

SIG Sistema de Informação Geográfica ou Sistema de Informação Georreferenciada

SSD Sistemas de Suporte a Decisões

SSD ABC Suporte a Decisões para Análise de Ondas de Cheia em Bacias Complexas

SWAT Soil and Water Assessment Tool

SWMM Storm Water Management Model 
$t \quad$ Duração da chuva

$\boldsymbol{t}_{\boldsymbol{o}} \quad$ Parâmetro da equação $I D F$

$\boldsymbol{T} \mathrm{T}$ empo em que a intensidade de chuva excede a capacidade de infiltração (Equação 12)

Tr Período de retorno

UFV Universidade Federal de Viçosa (MG)

URL Uniform Resource Locator - Localizador Padrão de Recursos

U.S. EPA U.S. Environmental Protection Agency

USP Universidade de São Paulo (SP)

U.S. SCS United States Soil Conservation Service

UTM Projeção Universal Transversa de Mercator

$v \quad$ Velocidade do canal (Equações 9 e 10)

$\boldsymbol{V} \quad$ Velocidade do escoamento (Equação 11)

$\boldsymbol{W}$ Taxa de infiltração média durante o período em que a intensidade de chuva excede a capacidade de infiltração (Equação 12)

WEPP Water Erosion Prediction Project

$\boldsymbol{x} \quad$ Estações com dados para comparação (Equações 18 a 22)

$\boldsymbol{y}$ Estação com os dados a serem preenchidos (Equações 18 a 22)

Yn Profundidade normal

$z \quad$ Inclinação do talude

ZCL Zona de Cisalhamento do Lenheiro

$\boldsymbol{\Delta H}$ Perda de carga - Lei de Darcy (Equação 13)

$\Delta p H$ Delta $\mathrm{pH}=\mathrm{pH} \mathrm{KCl}-\mathrm{pH} \mathrm{H} \mathrm{H}_{2} \mathrm{O}$ (Equação 16)

$\boldsymbol{\varphi} \quad$ Intensidade média de precipitação acima da qual o volume de chuva se iguala ao volume de escoamento superficial 


\section{Sumário}

1. INTRODUÇÃO ............................................................................................................26

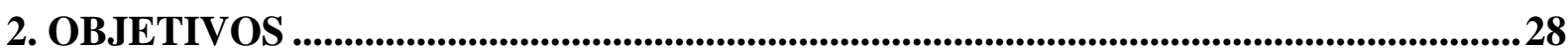

3. REVISÃO BIBLIOGRÁFICA ...................................................................................28

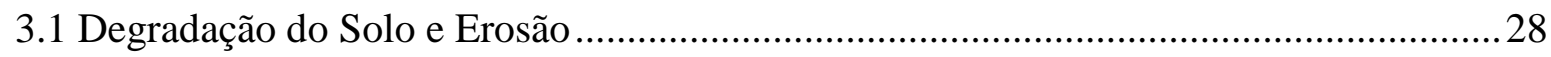

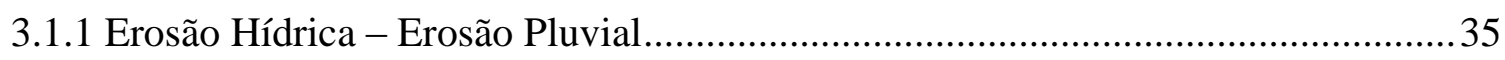

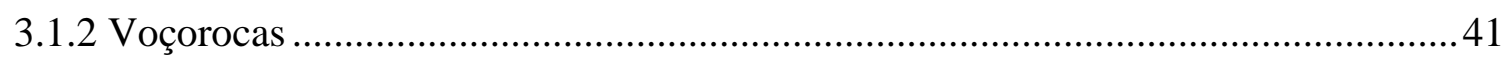

3.2 Recuperação de Áreas Degradadas por Processos Erosivos .......................................... 44

3.2.1 Sistemas de Drenagem na Recuperação de Áreas Degradadas ............................... 49

3.3 Sistemas de Informação Geográfica (SIG) .......................................................... 65

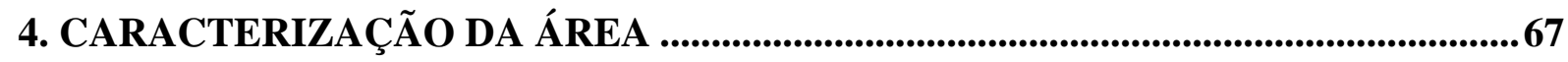

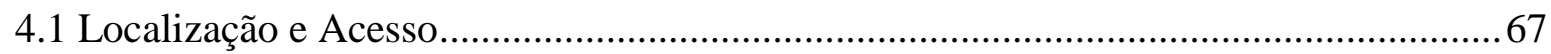

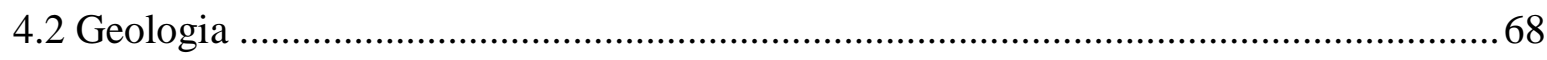

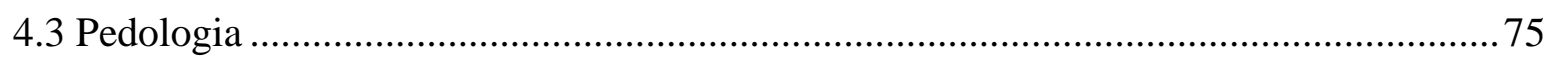

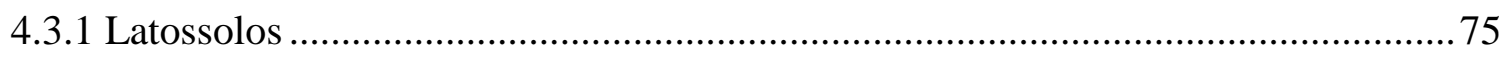

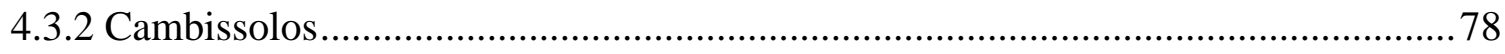

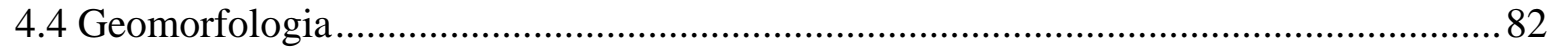

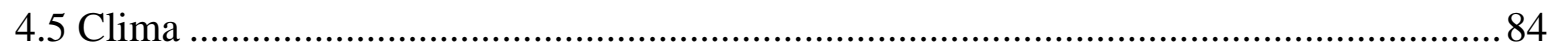

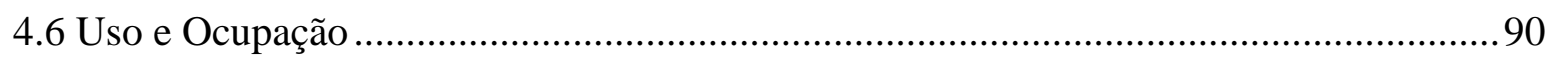

5. MATERIAIS E MÉTODOS ..........................................................................................94

5.1 Levantamento de Dados e Campanha de Campo ......................................................... 94

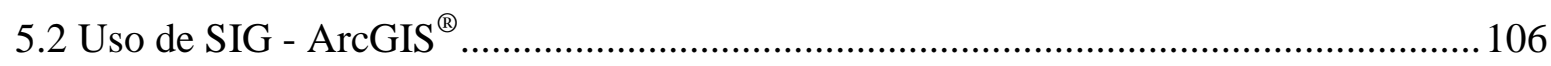

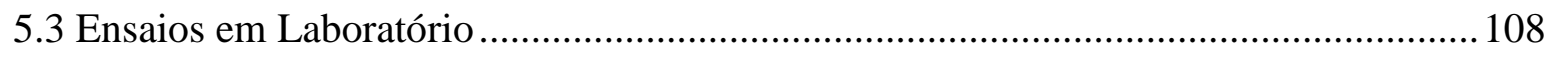

5.3.1 Ensaio de Condutividade Hidráulica a Carga Constante ........................................108

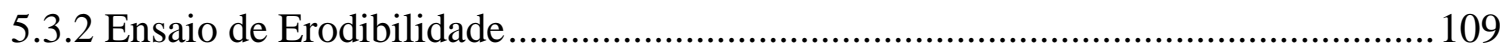

5.3.3 Ensaio para Obtenção de Delta pH, de CE e de Eh .............................................. 112

5.3.4 Ensaio de Oxidação da Matéria Orgânica ........................................................... 113 
5.3.5 Ensaio de Classificação de solos - Miniatura, Compactada, Tropical (MCT) e análise granulométrica conjunta. 115

5.3.6 Microscopia Eletrônica de Varredura (MEV) e Espectroscopia de Energia Dispersiva (EDS) 116

5.4 Tratamento dos Dados Pluviométricos 117

5.5 Estudo Preliminar do Disciplinamento da Drenagem - Voçoroca do Córrego do Cravo . 126

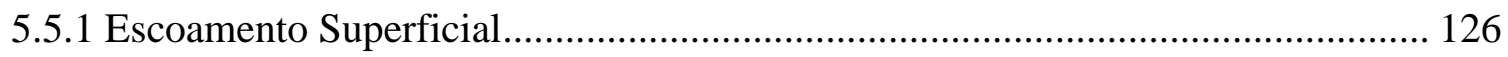

5.5.2 Drenagem do Escoamento Subterrâneo ................................................................. 128

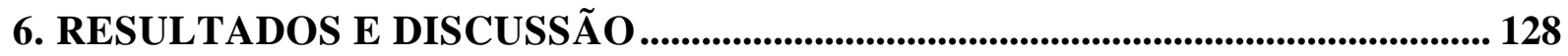

6.1 Análise Integrada: ArcGIS ${ }^{\circledR}$ e Dados de Campo................................................. 128

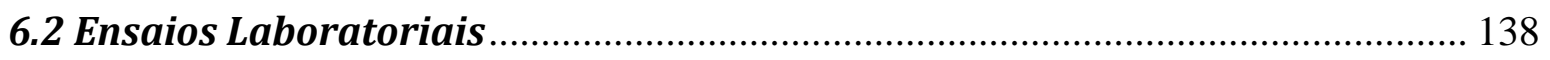

6.2.1 Ensaio de Condutividade Hidráulica a Carga Constante ..................... 138

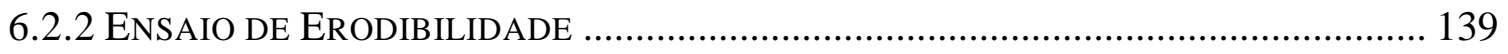

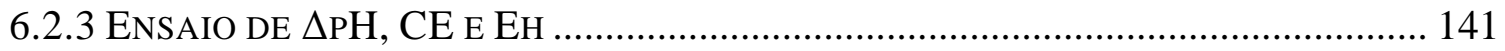

6.2.4 ENSAIO DE OXIDAÇÃO DE MATÉRIA ORGÂNICA................................................. 144

6.2.5 Ensaio de Classificação de Solos - Miniatura, Compactada, Tropical (MCT) E ANÁLISE GRANUlOMÉTRICA CONJUNTA …............................................... 145

6.2.6 Microscopia Eletrônica de VARredura (MEV) E Espectroscopia de

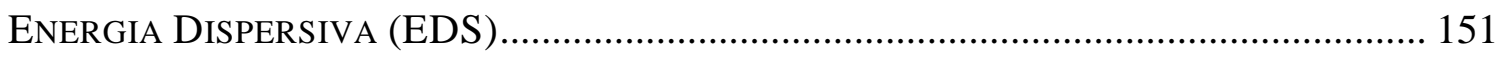

6.3 Avaliação dos Dados Pluviométricos e da Bacia ................................................ 166

6.4 Concepção de Projeto de Drenagem - Propostas para a Voçoroca do Córrego

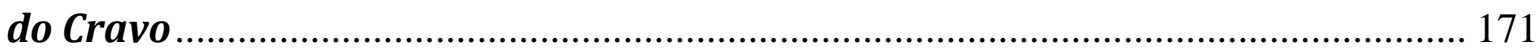

6.4.1 BACIA DE CONTRIBUIÇÃO - VOÇOROCA DO CÓRREGO DO CRAVO...................... 171

6.4.2 Área InTERna dA VoçOROCA - Drenagem da Água SubSUPERFICIAL ........ 193

6.4.3 PROPOSTA AdICIONAL - ESTRADA DE TERRA ..................................................... 202

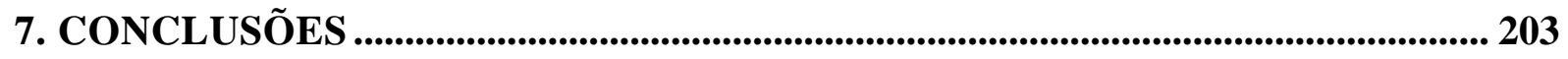

8. RECOMENDAÇÕES ..................................................................................................................... 206

9. REFERÊNCIAS BIBLIOGRÁFICAS ....................................................................... 207

ANEXOS 



\section{INTRODUÇÃO}

A partir da década de 1970, o gerenciamento ou administração das questões ambientais, quer seja para esclarecer e resolver um problema ou para criar bases para a tomada de decisões, vem ampliando-se no âmbito de não se limitar a uma ou outra área compartimentada da ciência, ou seja, vem se tornando cada vez mais interdisciplinar. Além de puramente científica e/ou governamental, a gestão ambiental historicamente também se dirige para abarcar a inclusão participativa da sociedade nas questões envolvendo a dinâmica de transformações dos sistemas naturais (BARROW, 2006).

Os diversos sistemas ambientais seguem leis naturais de causa e efeito. Ao mesmo tempo em que estas leis aparentam ser simples, podem se tornar complexas e até levarem a problemas significativos à medida que se manifestam de forma interligada e ampliada.

Os processos erosivos fazem parte destes sistemas. Observados de forma simples, são processos onde a causa do transporte e deposição de partículas é a desagregação destes elementos, e seu efeito é a modelação da paisagem. Este processo é considerado natural, e por ocorrer em escala de tempo geológico, o mesmo não é percebido pela escala de vida humana. Tal processo só é percebido, quando o equilíbrio dinâmico entre desagregação e formação do solo é interrompido, desta forma a perda de solo é maior que sua formação, resultando, em muitos casos, em problemas à população.

Nesse sentido, existem algumas condições ambientais que podem favorecer o aparecimento de erosões, como tipos de solos e suas características físico-químicas, litologia e estruturas geológicas, cobertura vegetal, declividade do terreno, forma das encostas, pluviosidade, oscilações do nível d'água subterrâneo, dentre outros; entender como estes condicionantes se relacionam e como a atividade antrópica pode modificar alguns destes fatores é imprescindível para compreender a estabilidade e a evolução dos processos erosivos. As voçorocas (feições erosivas de grande porte), por exemplo, podem ser desencadeadas por uma combinação complexa desses fatores, causando, na maioria das vezes, prejuízos à sociedade.

A bacia hidrográfica do Rio Grande, em Minas Gerais, é uma região que apresenta diversas feições erosivas de grande porte. Várias pesquisas têm sido realizadas para 
compreender quais são as características que levam ao desenvolvimento de erosões dessa dimensão (SILVA, 1990; TOLEDO, 2002; FERREIRA, 2005; HORTA, 2006; SILVA, 2006; FERREIRA et al., 2007; FERREIRA, 2008; FERREIRA; FERREIRA, 2009; HORTA et al., 2009; LACERDA et al., 2009; FERREIRA et al., 2011; MAGRI, 2013; OLIVEIRA et al., 2013; SAMPAIO et al., 2013). Em especial, a zona dos Campos das Vertentes, localizada na sub-bacia do Alto Rio Grande, apresenta quase uma centena de voçorocas (FERREIRA, 2011); estes estudos apontam para uma característica de susceptibilidade natural desta região, ao mesmo tempo em que apresentam a influência das atividades antrópicas como agente acelerador de tais processos. No município de Nazareno, em específico, são encontradas quase 60 voçorocas (FERREIRA, 2005), sendo esta cidade escolhida para o desenvolvimento desta pesquisa.

Desde a década de 1990 são realizados trabalhos de investigação dos tipos e usos do solo em regiões vizinhas à Nazareno, visando verificar os principais condicionantes associados na formação das voçorocas (SILVA, 1990). A partir do ano 2000 houve significativo aumento do detalhamento das pesquisas em relação aos compartimentos do ambiente que poderiam contribuir para o desenvolvimento das voçorocas no município (TOLEDO, 2002; FERREIRA, 2005; HORTA, 2006). Também houve intervenções junto às voçorocas para que seus impactos para a população fossem reduzidos ou mesmo eliminados (FERREIRA; FERREIRA, 2009). Porém, estes processos erosivos persistem como cicatrizes no ambiente, e permanece, também, a necessidade de uma consideração sistêmica de seus condicionantes e a utilização concreta de um planejamento e ação da gestão ambiental nas áreas impactadas pelo voçorocamento.

Diante disso, esta pesquisa foi concebida em consenso com a Organização Não Governamental (ONG) Projeto Maria de Barro (principais gestores na recuperação de voçorocas em Nazareno) e em conjunto com a pesquisa da aluna Maria Paula Pires de Oliveira (do Departamento de Geotecnia da Escola de Engenharia de São Carlos), orientada pelo prof. Dr. Osni José Pejon, com os quais se formou uma equipe para atuar no estudo geológico e geotécnico dos processos erosivos ocorrentes em Nazareno. Assim, a presente pesquisa avaliou características geológicas e geotécnicas relacionadas aos Latossolos e Cambissolos (mencionados no estudo como solo saprolítico), bem como o comportamento pluviométrico da região, os quais serviram de suporte para a elaboração de propostas visando à melhor condução das águas superficiais e subsuperficiais, principais fatores atuais de 
deflagração de escorregamentos e reativação de processos erosivos na voçoroca do Córrego do Cravo.

\section{OBJETIVOS}

O objetivo desta pesquisa foi avaliar os principais condicionantes geológicos e geotécnicos associados à voçoroca do córrego do Cravo em Nazareno (MG), visando à proposição de medidas de recuperação que tivessem por finalidade a condução adequada das águas superficiais e subsuperficiais.

\section{REVISÃO BIBLIOGRÁFICA}

\subsection{Degradação do Solo e Erosão}

O processo de degradação do solo pode ser compreendido como a deterioração das propriedades deste recurso natural, isto é, quando uma ou mais de suas funções que se encontravam em equilíbrio são modificadas e/ou perdidas. Pode ser subdividida em: química, na qual se observa o empobrecimento dos nutrientes presentes no solo devido à lixiviação; física, onde se verifica a desorganização estrutural das partículas; e biológica, em que ocorre alteração dos processos biogeoquímicos, e como consequência, a redução ou a eliminação de alguma população do solo (MACHADO, 2008). A degradação também pode ser entendida como a perda da funcionalidade ou potencial de funcionalidade, ou ainda a redução, alteração 
ou eliminação de características ou organismos que não podem ser substituídos no solo (BARROW, 1991).

As funções e usos do solo estão diretamente ligados a formas específicas de trocas de energia; sendo assim, pode-se definir a degradação do solo também como uma perda ou redução desta energia. Com este conceito é possível entender a distinção entre os processos naturais que ocorrem no solo (inter-relação entre a energia solar, a gravidade, chuva, ventos, dentre outros, e os elementos do sistema, que levam ao caminho natural de maior à menor energia) e a degradação do solo causada pela ação humana (competição de atividades como agricultura, indústrias, transformações geogênicas entre si e entre os elementos dos sistemas naturais) (BLUM, 1998).

Para estudar a degradação do solo em relação ao desgaste, transporte e deposição das partículas, o termo erosão como forma de denominar tal degradação foi inicialmente introduzido por McGee em 1911, consolidando-se nos trabalhos de Ayres, em 1936, Bennett, em 1939, e de outros pesquisadores em meados da década de 1930 (ZACHAR, 1982).

Diversas pesquisas, tais como as de: Frenzel (1980), Zachar (1982), Bitar e Braga (1995), Agassi (1996), DAEE/IPT (1989), Fendrich et al. (1997), Lal et al. (1998), Lal (2001), Bertoni e Lombardi Neto (2005), Morgan (2005), discorrem sobre a erosão como sendo a desagregação, remoção e transporte das partículas do solo causadas por agentes como gelo, vento, água (chuva, oceanos e rios), que irão se depositar em locais a jusante, sendo que estes processos podem ocorrer sob condições não perturbadas ou naturais, isto é, que fazem parte do equilíbrio do meio e/ou acelerados pela ação do homem, que causa o aumento na taxa de erosão e na produção de sedimentos.

Não necessariamente a erosão está associada a malefícios e prejuízos. O transporte e deposição de sedimentos naturalmente gera disponibilidade de solos férteis, à medida que os retrabalha, aprimora a umidade e enraizamento da vegetação, sendo estes solos amplamente utilizados para a agricultura ao longo da história, como no Vale do Rio Indo e no Delta do Rio Nilo (LAL, 1998; SILVA; SCHULZ; CAMARGO, 2004).

Além dos agentes, para que ocorram os processos erosivos é necessário que existam alguns condicionantes específicos no ambiente (CHRISTOFOLETTI, 1974; PEJON, 1992; FENDRICH, 1997; SILVA; SCHULZ; CAMARGO, 2004; BERTONI; LOMBARDI NETO, 2005), sendo esses listados a seguir: 
- Clima: alguns dos agentes erosivos são dependentes do clima do local, o qual envolve as variações de velocidades dos ventos, de temperaturas, e de precipitações; a este último fator é importante observar-se a intensidade (principal influência para a erosão), duração e frequência das chuvas, podendose ter, ainda, como característica a se avaliar a erosividade (capacidade da chuva ocasionar erosão, função da energia por unidade de área da gota de chuva). Os locais com clima úmido, tropical quente ou temperado, com inverno seco e verão chuvoso, proporcionam condições favoráveis para o aparecimento de erosões.

- Topografia: em relação a este condicionante, pode-se considerar o comprimento de rampa, declividade, forma e recobrimento das encostas como sendo principais aspectos geomorfológicos influenciadores nos processos erosivos. Observa-se na Figura 1 que a concentração do escoamento, por exemplo, pode ser dependente da forma da encosta de um terreno; locais que se apresentam levemente ondulados a muito acidentados, com maior densidade de drenagem e sem cobertura vegetal, em geral, estão mais propensos ao surgimento de processos erosivos. 


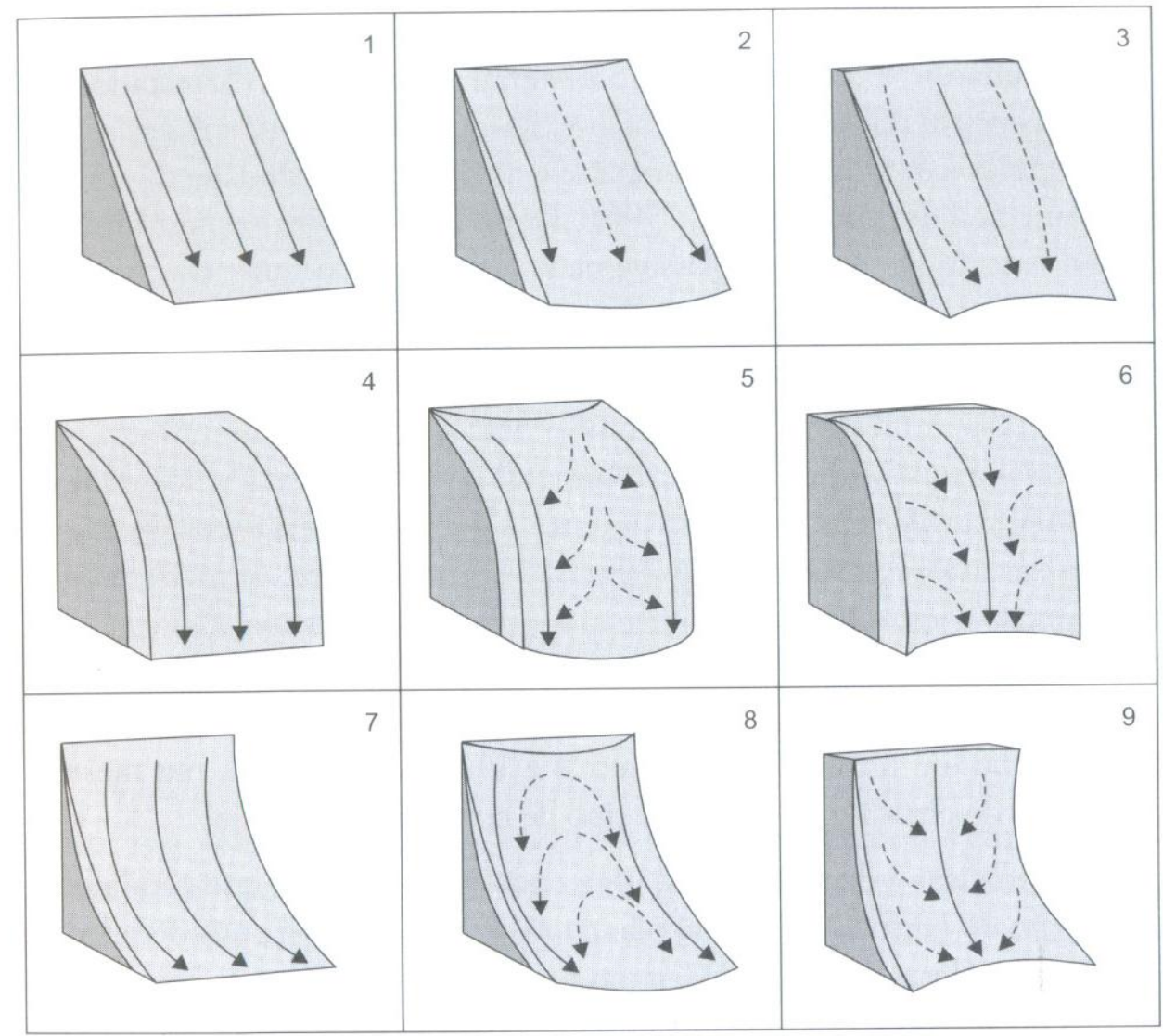

Figura 1 - Geometria e declividades em encostas retilínea, convexa e côncava.

1: Vertente retilínea nos sentidos vertical e horizontal; 2: Vertente retilínea no sentido vertical e convexa no sentido horizontal; 3: Vertente retilínea no sentido vertical e côncava no sentido horizontal; 4: Vertente convexa no sentido vertical e retilínea no sentido horizontal; 5: Vertente convexa nos sentidos vertical e horizontal; 6: Vertente convexa no sentido vertical e côncava no sentido horizontal; 7: Vertente côncava no sentido vertical e retilínea no sentido horizontal; 8: Vertente côncava no sentido vertical e convexa no sentido horizontal; 9: Vertente côncava nos sentidos vertical e horizontal.

Seta pontilhada: tendência de fluxo de canal inicial; Seta cheia: tendência de fluxo de canal concentrado. (RODRIGUES, 1982 apud SILVA; SCHULZ; CAMARGO, 2004).

- Geologia: além da ocorrência do intemperismo e formação do solo, as rochas encontradas em uma dada região podem estar susceptíveis às ações erosivas à medida que estiverem expostas ou apresentarem alguma estrutura que proporcione o contato com os agentes erosivos. É possível ainda que exista variação da intensidade do processo erosivo em um mesmo grupo de rochas, porém, exposto a diferentes climas e circunstâncias.

- Solo: os tipos de solos, sua granulometria e estrutura, os horizontes e sua espessura, porosidade, permeabilidade, presença de matéria orgânica, coesão, o 
tipo (ou ausência) de cobertura vegetal, dentre outros, são fatores que podem influenciar drasticamente a susceptibilidade à erosão de solos em uma região, que pode ser caracterizada pela erodibilidade (potencialidade das partículas de serem destacadas e carreadas). Pode haver facilidade de arraste e permeabilidades distintas em solos pouco coesos e porosos, ou quando ocorre alteração súbita de textura nos contatos dos horizontes, por exemplo, o que favorece o aparecimento de erosões e até de voçorocas.

No entanto, as intervenções humanas no uso do solo podem desencadear a erosão à medida que o expõem ou alteram suas propriedades físicas, como o desmatamento, agricultura e pastagens realizadas sem manejo adequado e de forma excessiva, abertura de estradas sem a realização de drenagens, execução de loteamentos e ocupação urbana sem planejamento, dentre outros (FENDRICH, 1997).

A remoção da cobertura vegetal, que expõe o solo antes protegido, é considerada a primeira causa da degradação; para áreas rurais, destacam-se a redução na fertilidade, à decomposição e mineralização da matéria orgânica, a lixiviação de elementos e nutrientes no perfil, e a erosão, como degradações originadas da intensa intervenção agrícola, mecanização e preparo do solo, que poderiam ser evitadas ao serem utilizadas técnicas preventivas e ações conservacionistas (FRENZEL, 1980). Para áreas urbanas, uma interação que cause a transformação das variadas funções do solo em apenas uma atividade a ser realizada em longo prazo, como as obras de infraestrutura e expansão (estradas, estacionamentos, dentre outras), é considerada uma das formas mais intensas de degradação do solo (BLUM, 1998).

Pimentel et al. (1987) analisaram em seu artigo alguns padrões de degradação do solo, a influência da erosão na produção de alimentos, medidas de controle de erosão para proteger solos bons para agricultura, fatores econômicos que afetam a erosão, os prejuízos off-site (isto é, as consequências ocorridas externamente ao local de origem da degradação) e políticas de conservação do solo e da água para controlar a erosão e o sistema de agricultura, confirmando que elevadas taxas de perdas de solo causaram o declínio da produtividade em muitos países; ainda, estimaram que, àquela época para os Estados Unidos, os custos com a erosão poderiam chegar a 43,5 bilhões de dólares anualmente em efeitos diretos e indiretos. Estudos empíricos de Clark, Haverkamp e Chapman (1985) e Warford (1987) apresentaram conclusões de que a 
degradação de solos rurais, além de causar déficit de produtividade na agricultura, podem resultar em danos off-site muitas vezes maiores que os observados na própria área degradada.

Já o aparecimento de erosões em áreas urbanas está relacionado com a ocupação sem planejamento adequado e por não considerar as condições físicas e sócio-econômicas do local (SALOMÃO; YWASA, 1995).

Del Grossi (1991) realizou trabalho de análise das voçorocas em área urbana de Uberlândia, Minas Gerais, apontando para uma questão recorrente em todo o país: entre os anos 1960 e 1980 houve grande expansão urbana, muitas vezes resultado de decisões econômicas e políticas, o que causou alterações geomorfológicas no ambiente e trouxe como consequências problemas, como ravinas e voçorocas. Carrijo e Baccaro (2000) também analisaram os processos erosivos da cidade e consideraram essencial o planejamento ambiental urbano na busca de se maximizar a eficiência da ocupação deste espaço, que deve, inclusive, reduzir os custos sociais dos empreendimentos, atentando-se para o fato de que a realidade está em constante mudança, isto é, os critérios devem ser mutáveis de acordo com o tempo e a demanda.

Em relação à quantificação da erosão, a Equação Universal de Perda de Solos tem sido muito utilizada por prover dados da taxa média de erosão por um período de tempo longo; entretanto, não é usual nas pesquisas se apresentar pontos importantes, o que pode tornar as informações obtidas com o uso desta equação insatisfatórias para o entendimento do problema de forma sistêmica, devendo ser ela estudada e utilizada com cautela (BOARDMAN, 2006). É interessante verificar e apresentar dados adicionais que complementarão as informações, como quais eventos contribuem para o processo erosivo ocorrer, locais e caminho de transporte e de deposição dos sedimentos, existência de vegetação, o escoamento superficial suficiente e a escala temporal e estabilidade do processo (BOARDMAN, 2006).

Boardman (2006), ainda realizou algumas revisões sobre a ciência referente à erosão em 1986, 1996 e 2006, sendo que o mesmo notou pequeno progresso na área em relação a questões como estudo das taxas de erosão, dos custos, dos modelos; verifica-se que existe falta de informações de campo e negligência por parte dos setores políticos, sociais e econômicos no que diz respeito aos processos erosivos. Este autor levanta algumas questões (Tabela 1) para se atentar quanto à erosão, que podem ser utilizadas como uma aproximação inicial ao problema, destacando a necessidade de o compreender em escalas menores e mais 
detalhadamente; estas questões vão de estritamente científicas até áreas de ciência social e gestão, sendo as maiores dificuldades encontradas na relação entre a ciência e os gestores (por exemplo, fazendeiros e governantes).

Tabela 1 - As grandes questões relacionadas à erosão (Adaptado de BOARDMAN, 2006).

\section{Questionamento}

\section{Pontos importantes}

\begin{tabular}{cc}
\hline Onde a erosão está ocorrendo? & Escala \\
\hline Hotspots globais & Conjunto de dados \\
\hline
\end{tabular}

Por que está ocorrendo?

- Motores sócio-econômicos; Causalidade

- Escoamento, vento, tipo de solo, etc.

Quando ocorreu/está ocorrendo?

- Alterações no tempo, sazonalidade, clima

Temporalidade

\begin{tabular}{cc}
\hline Quem a causou? & Responsabilidade \\
\hline Quão séria é? & Impactos, economia \\
\hline Algo pode ser feito a respeito? & Responsabilidade \\
\hline Existe risco de erosão futura? & Previsão \\
\hline
\end{tabular}

Além de fatores físicos ligados aos processos erosivos, que os tornam variavelmente distintos, severos ou frequentes em todo o globo, existe forte influência de atores sociais, econômicos, políticos e institucionais nas variáveis de espaço e tempo destes processos. Diante disso, as práticas de conservação do solo necessitam conter o entendimento e conhecimento em detalhe das condições atuais das erosões (MORGAN, 2005). DAEE/IPT (1989) corroboram a afirmação de que o embasamento para que se tornem possíveis a prevenção do desenvolvimento de processos erosivos se encontra na investigação das condições do ambiente (solo, clima e dinâmica dos recursos hídricos), que apresentam peculiaridades e susceptibilidades distintas para os diversos usos do terreno. Esta perspectiva e ação preventivas envolvem o direcionamento dos usos do solo com prioridade para medidas de conservação destes recursos naturais, que deveriam ser adotadas no âmbito da política urbana e rural, à medida que se avançam as obras de infraestrutura.

Dentre os tipos de processos erosivos existentes de acordo com o agente transportador, a erosão hídrica se destaca como mais notável em sentido mundial, pronunciando-se em locais 
que apresentam climas com verão chuvoso e inverno seco, devido à intensidade pluviométrica e à formação do escoamento superficial (ZACHAR, 1982; FENDRICH, 1997).

\subsubsection{EROSÃo HídRICA - EROSÃo PlUVIAL}

Dois aspectos são fundamentais no que concerne à avaliação da problemática da erosão hídrica: a ocorrência de precipitação (clima) e a exposição do solo (atividades antrópicas) (FAVIS-MORTLOCK; GUERRA, 1999). Ao observarem-se estes fatores, pressupõe-se que, para estes tipos de processos erosivos, as mudanças climáticas poderiam ser decisivas na alteração ou criação destes processos; entretanto, é verificado que as mudanças no uso da terra influenciam preponderantemente e até propiciam a ocorrência de tais eventos (FAVIS-MORTLOCK et al., 1997 apud FAVIS-MORTLOCK e GUERRA, 1999). Um exemplo seria a ocorrência de erosões em solos no extremo noroeste do estado do Paraná, que em condições de cobertura vegetal adequada, mesmo com elevada susceptibilidade à erosão, se mantinha estável, apresentando somente o desenvolvimento de processos erosivos com a retirada desta cobertura (FRENZEL, 1980).

Na América do Sul, 123 milhões de hectares de terra já foram degradados pela erosão hídrica, o que representa cerca de 11,24\% do total mundial de degradação (OLDEMAN, 1994 apud LAL, 1998). Majoritariamente, as áreas afetadas na América Latina são os planaltos da América Central, a região Andina, a República Dominicana, o Haiti, e a região de Cerrados, sendo as principais causas de erosão a deficiência de medidas conservacionistas de uso do solo, a gestão inadequada deste recurso e o acentuado uso da mecanização no campo (LAL, 1998).

Em termos de processo físico, a erosão causada pela ação da água, especificamente pela precipitação, tem início com o impacto das gotas de chuva no solo, causando a desagregação das partículas. A remoção e o transporte destas partículas podem ser realizados tanto pela ação das gotas da chuva como pelo escoamento superficial. A princípio, o processo erosivo é maior no inicio da chuva, tendendo a diminuir quando há formação da lâmina d'água (FRENZEL, 1980; FENDRICH, 1997). No momento em que ocorre a interceptação 
do lençol freático, o processo erosivo é acelerado, e isto ocorre de forma pontual ou em uma linha, podendo representar o nível piezométrico do local (IDE, 2009).

Considera-se a deposição do material como a última etapa da erosão hídrica, ou seja, quando a energia do agente é reduzida o bastante para não conseguir mais carreá-lo ou quando este material encontra um obstáculo fazendo sua velocidade diminuir ou forçando sua parada (FENDRICH, 1997).

A erosão hídrica pode ser subdividida em duas categorias: superficial, causada pelo processo de desagregação do solo pelas gotas da chuva e seu carreamento pelo escoamento de fluxo concentrado e não concentrado, e subsuperficial, causada pelo transporte de partículas no interior do solo (CARSON; KIRKBY, 1975 apud PONS, 2006).

A erosão superficial é associada ao escoamento que tem capacidade de desagregar, transportar e depositar as partículas do solo, sendo considerado um agente importante de processos erosivos (LAL, 1990 apud ROTTA, 2012). Ocorre na superfície de solos expostos ou parcialmente expostos, geralmente dividida em quatro estágios, de acordo com o prosseguimento no tempo e a localização no terreno, sendo eles: erosão por embate ou salpicamento, laminar, por canais e linear (BENNETT, 1974 apud FENDRICH, 1997).

Burton (1968 apud Rodrigues, 1982) apontou que a erosão subsuperficial pode se relacionar com a existência de uma camada mais impermeável localizada abaixo de uma mais permeável. Ou seja, neste tipo de desagregação e transporte de material que ocorre em profundidade no perfil, à medida que a água encontra materiais com permeabilidades reduzidas, estas poderão causar a transição de movimentação do escoamento para predominantemente horizontal. Esta movimentação pode levar à abertura de condutos, valas e/ou sulcos na lateral dos taludes, causando sua desestabilização (FENDRICH, 1997).

Em resumo, a erosão subsuperficial se dá com a retirada das frações finas do solo através do escoamento da água com a gravidade por entre agregados e partes grosseiras ao longo do perfil. Em geral, quanto maior a porosidade e a proporção de poros que não sofrem capilaridade, nos quais a movimentação da água no solo é livre, o fluxo se torna mais veloz e mais partículas são carreadas através do escoamento subterrâneo. Este tipo de erosão apresenta impacto tanto ecológico quanto geomorfológico, pois reduz a estabilidade do solo e indiretamente acelera os outros processos erosivos (ZACHAR, 1982). 
A Figura 2 ilustra um exemplo de erosão subsuperficial.

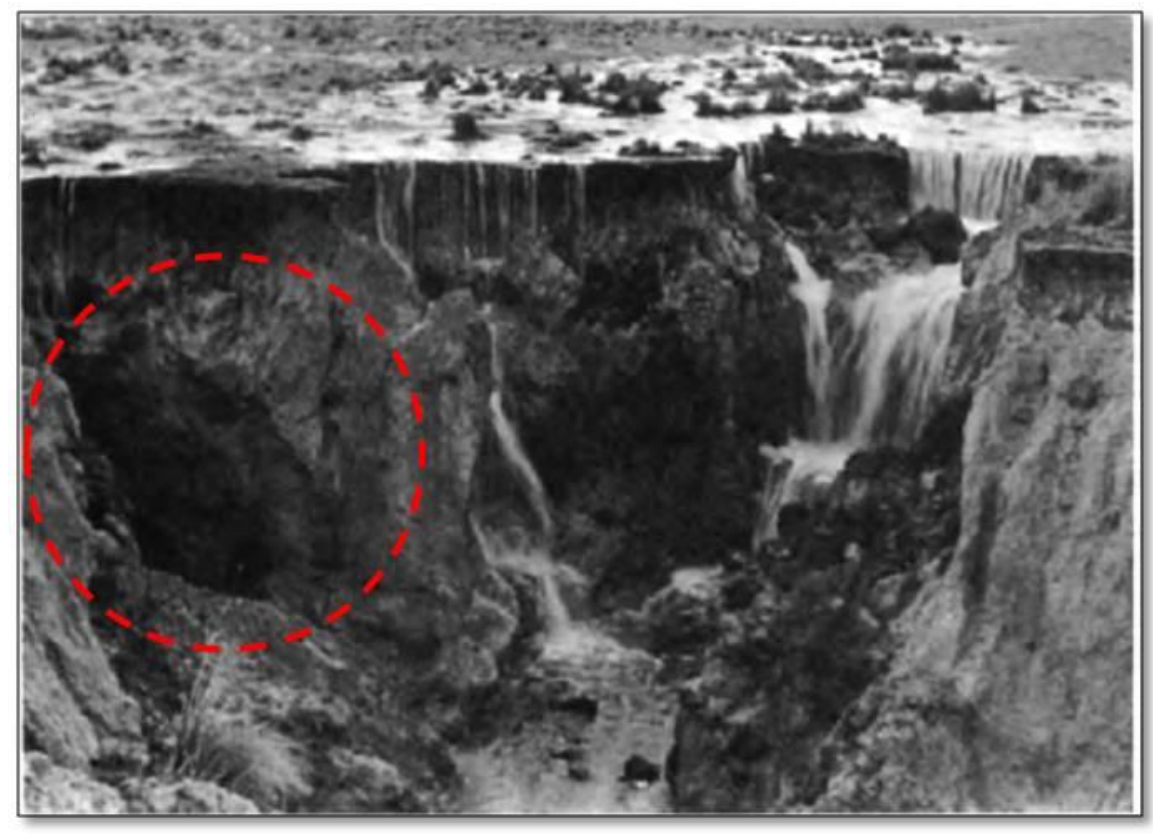

Figura 2 - Voçoroca com erosão subsuperficial (Adaptada de ZACHAR, 1982).

\subsubsection{Erosão por embate ou salpicamento}

Este tipo de erosão é ocasionado pelo impacto das gotas de chuva que projetam as partículas do solo no ar, acabando por desintegrar os agregados de forma parcial, liberando os finos para o transporte (FENDRICH, 1997). A velocidade e energia com que as gotas da chuva irão desagregar as partículas do solo são dependentes de seu diâmetro (BERTONI; LOMBARDI NETO, 2005).

O impacto causado pelas gotas da chuva podem também selar a superfície do solo, compactando-o e diminuindo a movimentação da água para o fluxo subterrâneo (TROEH et al., 1980 apud FERREIRA, 2005). 


\subsubsection{Erosão laminar}

É caracterizada pela forma como ocorre o desgaste do solo, no qual se apresenta um deslizamento em superfície ou lâminas carreadas pelo escoamento de água, o que a torna conhecida por sheet erosion (erosão em lençol). Pode ser observada através do decréscimo de produção agrícola e aparecimento de raízes, mas sua percepção é difícil de ser realizada; ocorre principalmente onde os solos são rasos acima de camadas impermeáveis, como solos argilosos (BENNETT, 1955 apud FENDRICH, 1997).

Mesmo em solos localizados em baixas declividades, quando utilizados com plantações que necessitam de movimentação excessiva, ao serem acometidos por chuvas com considerável intensidade perpassam pela erosão laminar, no processo de retirada de camadas superficiais que também são detectadas pela turbidez das águas e ligeiro assoreamento a jusante, no terreno (FRENZEL, 1980). É possível verificá-la, também, através da coloração do solo, que se torna mais claro (BAHIA et al., 1992).

A erosão laminar, por ser de difícil percepção, pode ser considerada a mais grave, pois, não sendo observada em sua fase inicial, pode ocasionar prejuízos e até conduzir a área aos outros tipos de erosão (FRENZEL, 1980), que serão abordados nos tópicos seguintes. A Figura 3 apresenta um exemplo de erosão laminar conduzindo a concentração em sulcos.

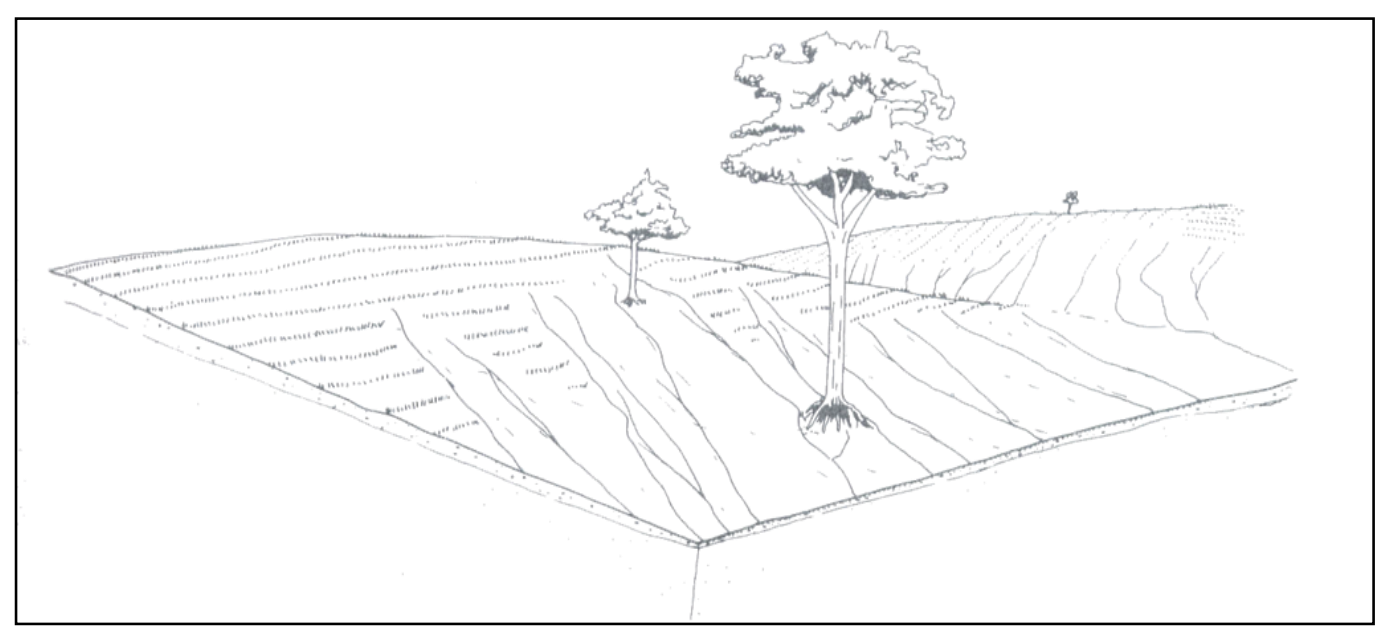

Figura 3 - Erosão por escoamento laminar e por escoamento concentrado, formando sulcos na superfície do terreno. (DAEE/IPT, 1989). 


\subsubsection{Erosão em córregos ou canais}

De maior facilidade para ser observada em relação à erosão laminar, porém, confundida com o início da linear, este tipo de processo erosivo é caracterizado pela formação de canais onde se concentra o fluxo superficial devido a variações no solo decorrentes de pequenas alterações na declividade. Também conhecida por rill erosion, em geral podem ser removidas facilmente por práticas agrícolas comuns (FENDRICH, 1997).

Existem distintas classificações em relação a este tipo de erosão, sendo que alguns autores a consideram como uma forma separada, ou como um aspecto da erosão laminar, ou ainda incluem nos termos de ravinas e voçorocas (ZACHAR, 1982).

\subsubsection{Erosão linear}

Neste tipo de erosão o fluxo de água tem um caminho preferencial (concentrado), gerando feições como: sulcos, ravinas ou voçorocas (BENNET, 1939 apud ZACHAR,1982).

Os sulcos são considerados como fissuras de maior ou menor profundidade no solo causadas pela concentração do escoamento superficial devido a irregularidades na inclinação do terreno (HUDSON, 1995), podendo ser estabilizadas através de intervenções simples no solo. Muitas vezes não se atenta sobre este tipo de erosão até que processos de preparo do solo, nas áreas rurais, e implementações de novos loteamentos e ruas sem pavimentação, em áreas urbanas, sofram sua interferência (IDE, 2009).

As ravinas são consideradas como aprofundamento dos sulcos, geralmente apresentando formato em $V$, não chegando a atingir o nível d'água e nem apresentando ramificações. Nesse caso, o avanço da erosão se dá através de movimentos gravitacionais de massa (CANIL et al., 1995 apud IDE, 2009) podendo levar à formação de voçorocas. A Figura 4 apresenta um exemplo de sulcos e ravinas. 


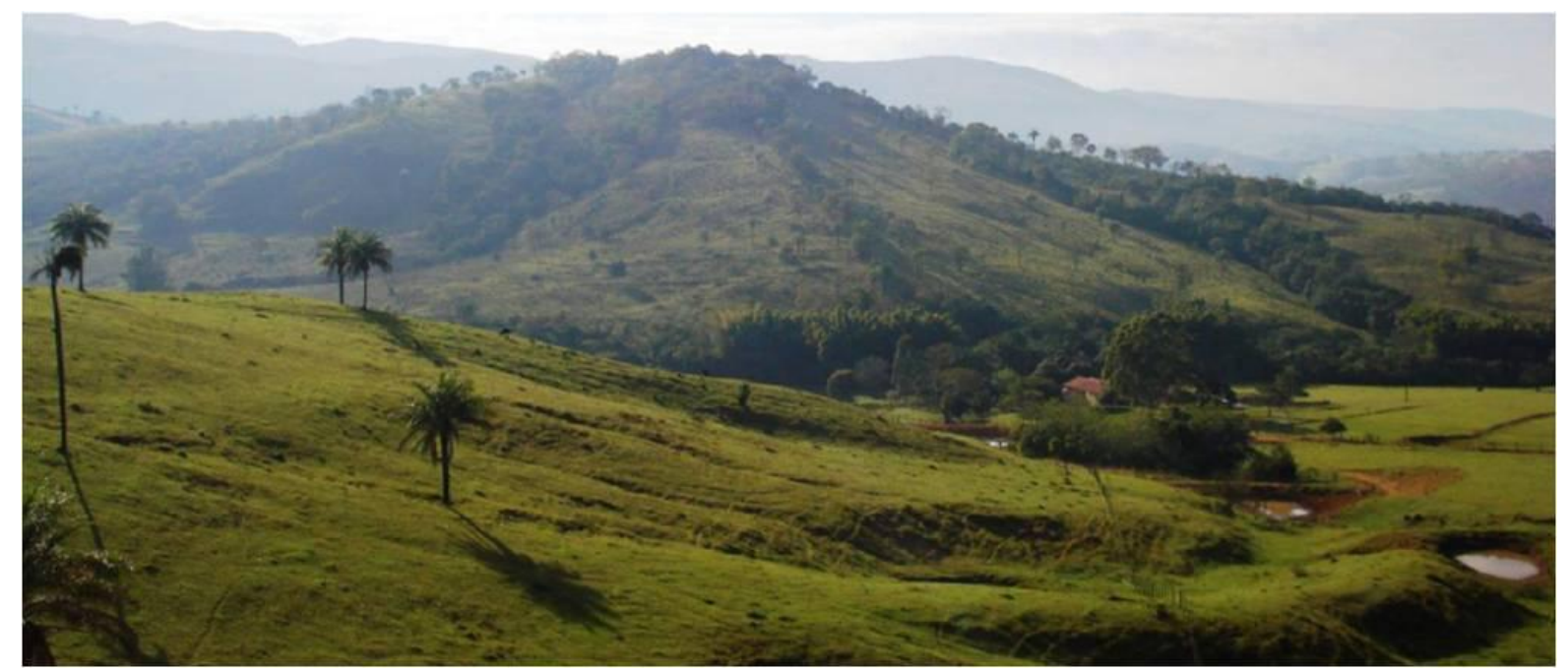

Figura 4 - Sulcos e ravinas causados por trilhas de gado em morros, na região do Médio Rio Grande (MG). (MAGRI, 2013).

As principais distinções entre ravinas e voçorocas estão ligadas às dimensões, formas e encontro com o nível d'água. O termo gully (escoadouro, escavação) erosion é utilizado pela associação com os efeitos nas bordas da erosão (ZACHAR, 1982). A Figura 5 exibe a morfologia dos sulcos, ravinas e voçorocas (ou boçorocas), mostrando a diferenciação entre estes processos erosivos na paisagem.

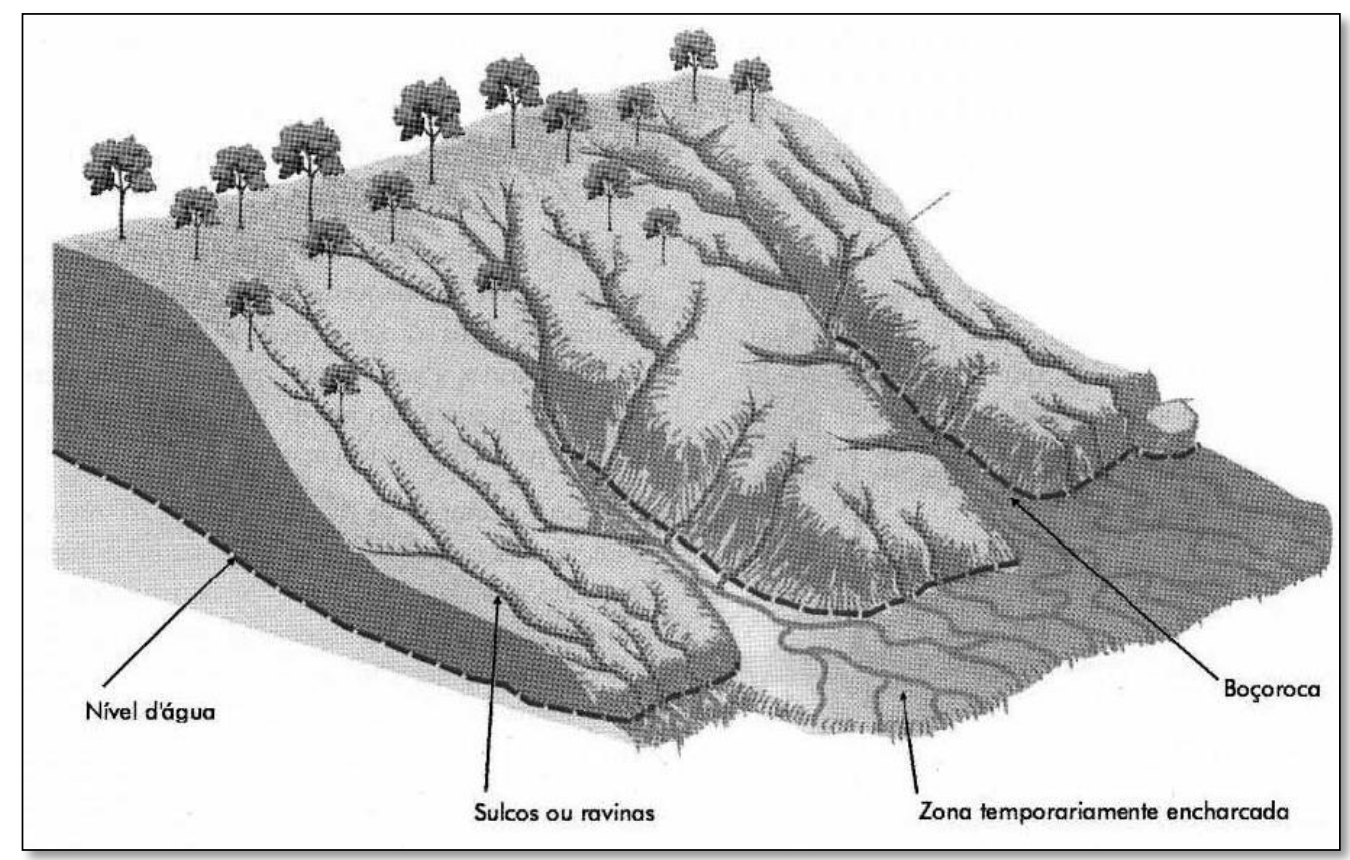

Figura 5 - Morfologia de sulcos, ravinas e boçorocas (KARMANN, 2000 apud PONS, 2006). 


\subsubsection{VOÇOROCAS}

O início da alteração do equilíbrio no ambiente está na retirada devastadora da vegetação, agravando-se o desequilíbrio com o manejo inapropriado do terreno. Algumas técnicas, mesmo que aparentemente inofensivas, como a separação de propriedades com valas e a passagem de animais em trilhas, em condições específicas, podem ser o estopim para o desenvolvimento de uma voçoroca (RODGRIGUES, 1982).

Comumente, a origem de uma voçoroca está associada à degradação de sistemas de drenagem superficiais, o que, em geral, ocorre em taludes de rodovias, em margens de estradas sem proteção, e em locais de cultivo em que os fluxos são direcionados a solos mais susceptíveis à erosão (EMBRAPA, 2005). O processo de falhas e deslizamentos que produz a conformação das voçorocas usualmente é divido em três etapas: etapa inicial de pré falha, relacionada diretamente com a dinâmica periódica e climática (volume de escoamento de água, degelo, encharcamento e secamento, quantidade de água no perfil do solo), a etapa da falha em si, geralmente relacionada com a ação da gravidade, e a etapa de remoção de material desprendido, influenciada principalmente pelos eventos chuvosos (GRISSINGER, 1996b).

As voçorocas ou boçorocas, dessa forma, são processos erosivos complexos com grau de evolução e aceleração que dificultam sua recuperação e controle, e acarretam em perdas econômicas (AYRES, 1936 apud ROTTA, 2012). Podem ser caracterizadas como feições íngremes compostas por cabeceira e regiões de variadas inclinações, apresentando grandes profundidades (MORGAN, 1995). Este tipo apresenta um conjunto entre erosão retromontante e vertical associadas à lateral, com escorregamentos das paredes, fluxo com solo ou outros fenômenos que a tornam de grande complexidade (ZACHAR, 1982). Devido a estes fatos, a suavização dos canais formados nas voçorocas torna-se muito dificultada por práticas agrícolas convencionais (BEASLEY, 1972).

Mesmo possuindo diversos mecanismos de formação ou agentes causadores, muitos autores compreendem que estes processos erosivos tendem a crescer principalmente a partir de atividade da água subsuperficial (HIGGINS, 1990). 
É possível classificar as voçorocas quanto à sua complexidade, idade, localização, quanto ao formato de sua seção transversal, ao tamanho, à profundidade, ao formato em planta, dentre outros. Como exemplos, em relação à forma de sua seção transversal, pode-se classificá-las em $U$ ou $V$ : as de formato em $U$ não necessariamente estão ligadas a perfis estabilizados e são comumente encontradas em locais onde o solo é mais susceptível à erosão, sendo que apresentam paredes quase verticais e ampliação lateral dada por erosão superficial ou por desabamento da base advindo da ação da água subsuperficial; as de formato em $V$ são presentes em solos com maior resistência à erosão, sendo que a ação da água superficial predomina em relação ao comportamento da subsuperficial. É comum encontrar os dois formatos em uma mesma voçoroca, mas em geral se associa o formato em $V$ ao início do processo erosivo (FENDRICH, 1997). A Figura 6 exibe a formação de voçorocas com os tipos de bordas em V e U, em conjunto com exemplos destas feições. 


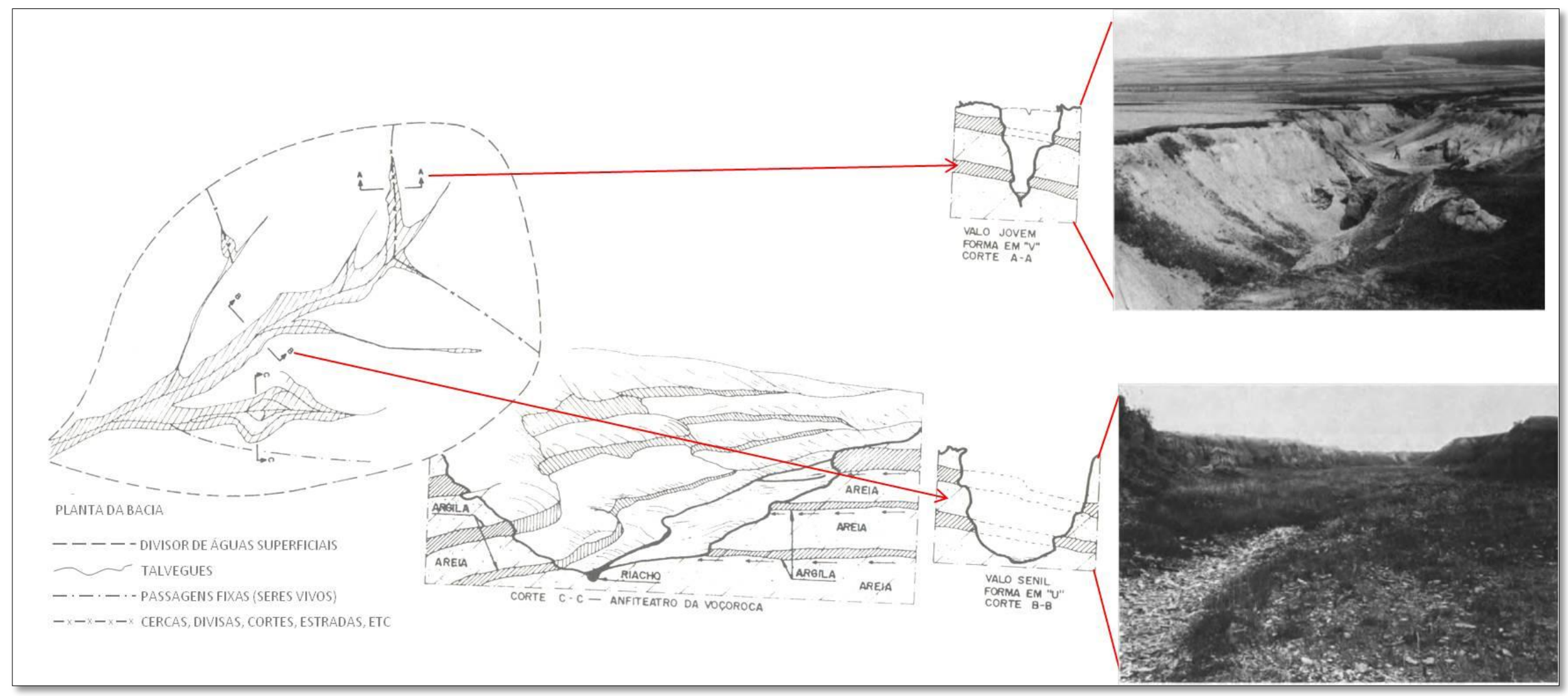

Figura 6 - Formação e desenvolvimento das voçorocas. (Modificada de FENDRICH, 1997 e ZACHAR, 1982) 


\subsection{Recuperação de Áreas Degradadas por Processos Erosivos}

Como vem sendo abordado, no momento em que um processo natural, como a erosão, por ter sido desbalanceado, apresentar prejuízo à alguma atividade como a agricultura ou ocupação urbana, a recuperação desta degradação é concebida visando dois objetivos principais: mitigação do prejuízo através da estabilização do processo, para que não cause mais danos, e/ou a elaboração de uma nova funcionalidade que contribua para a população.

Assim, a recuperação ambiental de uma área degradada pode ser diferenciada entre restauração e reabilitação. A restauração pode ser definida como sendo o retorno de todas as interações existentes antes da degradação (no caso de processos erosivos de grande porte, este tipo de recuperação é inexistente, devido sua complexidade). Já a reabilitação, mais comumente utilizada, é considerada como o planejamento de um novo uso para a área degradada, de tal forma que o equilíbrio natural retorne. No caso da reabilitação, não necessariamente se retorna às condições originais do local (ABNT, 1989). Quaisquer técnicas que visem à melhoria das condições do meio físico, tornando-o apto para novas utilizações, podem ser consideradas como ações de recuperação ambiental (SÁNCHEZ, 2006).

As intervenções junto aos processos erosivos devem ter como base fundamental a diminuição das perdas de solo para um nível de tolerância ou de segurança, de forma que se restabeleça um equilíbrio (MORGAN, 2005). Deve-se manter o foco na observação do fenômeno e seus condicionantes para determinação dos métodos de melhoria das propriedades do solo erodido (ZACHAR, 1982), pois, assim que se consegue controlar as origens do problema, o próprio solo tem condições de se recuperar (LAL et al., 1998).

Para controlar a evolução de erosões, AYRES (1936 apud ROTTA, 2012) e MORGAN (1995) apontam a importância de se ter uma visão a longo prazo, da melhoria de formas de drenagem e infiltração da água, de medidas que levem em conta a perda de solo a condições aceitáveis e de um planejamento de formas de se controlar os depósitos dos materiais erodidos. Segundo Pontes (1980), fundamentais para o controle da erosão são o conhecimento da vazão a ser suportada, a declividade e as condições do terreno. 
A Figura 7 apresenta um diagrama que aponta procedimentos para a tomada de decisão nos processos de gestão de um problema ambiental que podem auxiliar no processo de planejamento de recuperação de uma área degradada por processos erosivos.

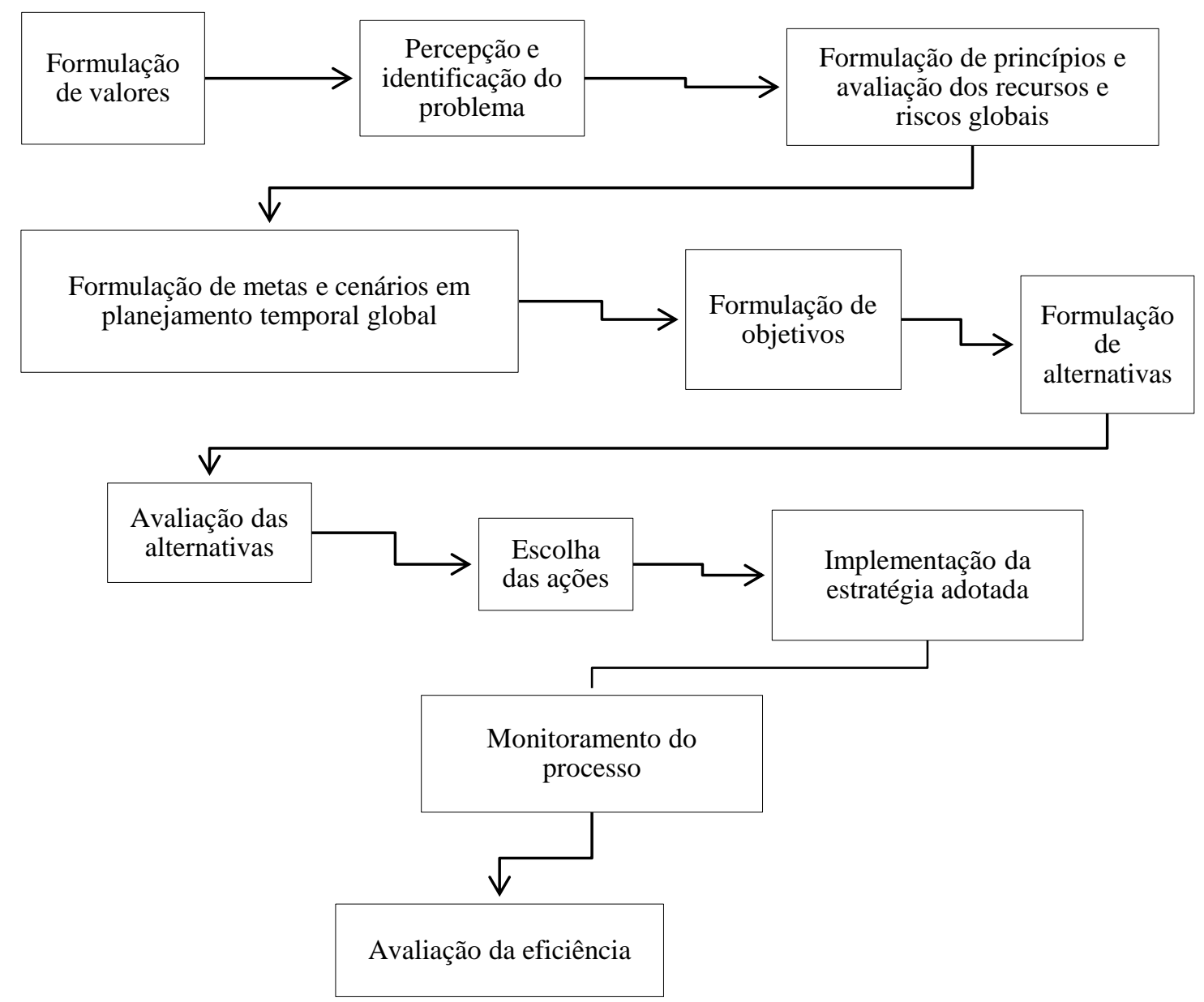

Figura 7 - Principais passos na tomada de decisão em um processo típico de gestão ambiental (Modificada de MATTHEWS et al., 1976 apud BARROW, 2006).

Rotta (2012) apresenta uma classificação das medidas de prevenção, controle, mitigação e recuperação de áreas afetadas por processos erosivos quanto ao tipo e ao objetivo a ser alcançado, sendo estas medidas divididas entre ecológicas, agrícolas, mecânicas, estruturais (macro e microdrenagem) e bioengenharia. Destaca que, para atingirem seus objetivos, as técnicas, além de serem implantadas de forma correta, devem levar em consideração os condicionantes geológico-geotécnicos, as condições hidrológicas e o uso posterior a ser dado para cada local a ser recuperado. Para cada situação é necessário que haja 
adequação dos níveis e estágios de recuperação de acordo com suas particularidades. (GRISSINGER, 1996b).

Em pesquisas reunidas por EMBRAPA (2011) é apontado que se deve primariamente proteger a região na qual a erosão se insere para evitar o acesso de máquinas agrícolas e gado, em caso de erosão rural, dessa forma, reduzindo-se a possibilidade de compactação do solo ao seu redor; em seguida, deve-se ter como foco a drenagem da água subterrânea, pois, principalmente no caso das voçorocas, poderão ser minimizados os movimentos remontantes deste tipo de erosão através do disciplinamento do nível d'água surgente e redução da ocorrência de erosões subterrâneas.

O reconhecimento e a quantificação da erosão são pontos importantes para se realizar atividades de recuperação. Boardman (2006) aponta que existe evidência considerável de que eventos de precipitação e escoamento ou uma sequência deles são responsáveis por erosões de elevadas dimensões, geralmente acompanhadas por danos off site. Devem-se monitorar eventos moderados por longos períodos de tempo; porém, fluxos de menores proporções e frequentes podem transportar solo e poluentes (pesticidas, por exemplo) e podem ser facilmente esquecidos, mesmo sendo também causadores de prejuízos.

Em geral, as técnicas utilizadas para recuperar uma área degradada por erosão hídrica possuem como funções básicas a diminuição da amplitude das forças desagregadoras, a proteção das superfícies erodíveis da ação direta destas forças e a redução do escoamento superficial. Estas condições podem ser atingidas, por exemplo, com o planejamento, implantação e manutenção adequados de canais de escoamento, que podem até evitar o surgimento de voçorocas através do impedimento da formação de novos sulcos (LAFLEN; ROOSE, 1998).

Araujo, Almeida e Guerra (2011) separam a metodologia para utilização de sistemas de estabilização em: construções vivas, as quais poderiam ser entendidas como o uso de gramíneas ou outros tipos de vegetação para estabilizar a erosão de modo habitual; construções inertes, como o uso de estruturas ou sistemas mecânicos convencionais aos quais se atribui a previsibilidade e invariabilidade de propriedades (aço e concreto, por exemplo); e construção mista, considerada como a utilização de bioengenharia, que se utiliza de materiais inteiros vivos ou partes deles, ou ainda uma combinação com material inerte, como estacas 
vivas e ramos, estruturas de terra, entre outros, para realizar a estabilização de encostas e drenos hidráulicos.

A revegetação de um local com exposição do solo se torna de extrema importância no que concerne à recuperação de uma área erodida, de forma que reduza o volume de escoamento superficial pela interceptação da água e melhore sua infiltração; além disso, esta prática pode auxiliar a produtividade agrícola no sentido de reinstalar a dinâmica de troca de nutrientes e ciclos biogeoquímicos no solo degradado (ZUAZO; PLEGUEZUELO, 2008). Estudo comparando diferentes coberturas utilizando folhas e adubo, em conformação de mantas, demonstrou serem muito eficientes no controle da erosão e na proteção do solo até o completo estabelecimento da vegetação, porém, com limitações em relação às dimensões e inclinação da área a ser implementada (BHATTARAI et al., 2011). Dentre outras técnicas que utilizam a vegetação, pode-se ainda citar as culturas em fileiras ou consorciamento de culturas, que auxiliam na redução da erosão laminar, as quais podem ser descritas como o cultivo em formato de linhas de tamanhos diversos, revezando-se com outras que possam realizar uma cobertura mais densa do solo, e a adubação verde (DIAS et al., 2000 e LIMA et al., 2006 apud EMBRAPA, 2011).

As técnicas denominadas bioengenharia do solo ou manejo biotécnico podem ser compreendidas como o emprego de material vivo (vegetação) em conjunto com material inerte convencional para auxiliar a prevenção ou estabilização de escorregamentos e processos erosivos, de forma que a união dos materiais possua funcionalidade geotécnica e hidráulica (GRAY; LEISER, 1982 apud DURLO; SUTILI, 2005 e ARAUJO; ALMEIDA; GUERRA, 2011).

Há registros de que essa abordagem técnica é encontrada na história de povos da Ásia e Europa antiga, como a construção de cestos tecidos por salgueiro, cânhamo ou bambu para conter margens de rio e barragens ou reparação de diques na China desde o ano de 28 a.C. (ARAUJO; ALMEIDA; GUERRA, 2011). Atualmente, os países que se destacam na utilização da bioengenharia são os do continente europeu e os Estados Unidos (SCHIECHTL, 1973 apud DURLO; SUTILI, 2005); no Brasil ainda existem dificuldades em sua utilização, podendo ser atribuídas à deficiência de conhecimento destas técnicas e dos materiais mais adequados a cada situação ou à preferência por outras mais comumente utilizadas ou facilmente implantáveis, que acabam por se tornar padronizadas, mesmo que erroneamente, na recuperação de áreas degradadas (DURLO; SUTILI, 2005; ROTTA; ZUQUETTE, 2013). 
Pode-se considerar que uma das metas principais em relação à utilização destas técnicas é atingir a funcionalidade e integração no ambiente com o máximo de simplicidade, para que esta alternativa possa ser compreendida e empregada, além de projetistas e empresas, por exemplo, por agricultores ou pessoas que queiram se informar e aplicá-las em sua propriedade rural (DURLO; SUTILI, 2005). Entretanto, destaca-se que estas técnicas não devem ser utilizadas em qualquer local ou situação, pois necessitam ser avaliadas as condições ambientais, o porte e a peculiaridade de cada problemática (ARAUJO; ALMEIDA; GUERRA, 2011).

O uso de geossintéticos, geotêxteis, geomantas e/ou biotêxteis, pode auxiliar, tanto isolados como em conjunto com obras de bioengenharia, na diminuição dos processos erosivos à medida que possuem, além da ação de cobertura e proteção do solo (reduzindo-se a energia de desgaste provocado pelas gotas de chuva), a capacidade de conter parte dos sedimentos que poderiam ser transportados pelo fluxo em superfície. Alguns destes materiais propiciam a introdução de água no perfil do solo, devido à redução do escoamento superficial e maior infiltração (FERNANDES et al., 2009; RODRIGUES; BEZERRA, 2010). Por este motivo, o crescimento e estabelecimento da vegetação são facilitados (RODRIGUES; BEZERRA, 2010).

Podem ser utilizados materiais que combinam estruturas inertes, como fios finos ou filamentos grossos de polipropileno, entrelaçados ou pulverizados com outros diversos, como negro-de-fumo, ou materiais mais facilmente degradáveis, como fibras de coco ou palha; ainda, a adição de vegetação no conjunto apresenta a tendência de melhorar o controle dos processos erosivos (FERNANDES et al., 2009).

O geotêxtil de juta, por exemplo, pode ser utilizado para auxiliar a drenagem em obras; sendo material biodegradável e não tóxico quando decomposto, pode ser uma alternativa eficiente no que concerne à resistência conferida à superfície do solo sem ser prejudicial ao ambiente. Caso seja necessário, a juta pode receber tratamentos distintos e sua durabilidade pode alcançar 5 anos (CHATTOPADHYAY; CHAKRAVARTY, 2009).

Sendo a erosão hídrica uma das principais degradações que assolam o Brasil, técnicas que visem o disciplinamento da água, tanto superficial quanto subsuperficial, tornam-se imprescindíveis no entendimento para o planejamento de recuperação de áreas degradadas por estes processos erosivos. 


\subsubsection{Sistemas DE Drenagem NA RECUPERAÇÃo DE ÁREAS DEGRADADAS}

O histórico das obras para drenar a água apresenta-se ser tão antigo quanto à agricultura em si. Os primeiros registros históricos gregos que se ainda mantêm preservados atribuídos a Heródoto, datados de aproximadamente 400 a. C., contêm algo citado sobre as obras de drenagem no Vale do Rio Nilo. Os problemas apresentados pelo excesso de escoamento superficial ou subsuperficial necessitam de atenção e tratamento, principalmente para melhorar a disponibilidade de alimentos e terras agricultáveis (LUTHIN, 1973). No caso específico das voçorocas, é importante destacar que estas obras apresentam função fundamental em sua recuperação, já que estes processos são desencadeados no momento em que o escoamento influencia o rompimento e movimentação do solo nas interações entre suas partículas com a própria água (GRISSINGER, 1996a).

O conceito de drenagem consiste em controlar a água para evitar que cause prejuízos em algum local ou obra. Em geral, a redução da resistência ao cisalhamento dos solos quando saturados, a variação de seu volume ao serem umedecidos, a anulação do atrito entre grãos de materiais granulares e a produção da força de arraste das partículas pelo fluxo em altas velocidades são alguns dos efeitos que as águas, tanto superficiais quanto subsuperficiais, causam no ambiente (MICHELIN, 1975).

Diante disso, a redução da energia de escoamento das águas pluviais em solos expostos, desprotegidos e/ou susceptíveis deve ser considerada como uma das finalidades principais de projetos de drenagem, e isto pode ser efetuado com o auxílio de obras como sarjetas, bocas de lobo e galerias (FERREIRA, 2004). Sendo assim, é estritamente necessária a utilização de critérios técnicos para a correta implantação de sistemas que auxiliem no controle de processos erosivos; Cruz e Silva (1995) realizaram estudos em várias estruturas que apresentaram deficiência em seus sistemas hidráulicos, instalados em Bauru, no estado de São Paulo, e apontaram que, muitas vezes, não se possui o devido conhecimento e experiência em situações que necessitam de entendimento em hidrologia, hidráulica e dinâmica de transporte de sedimentos. Rotta e Zuquette (2013) apontam, ainda, que no Brasil, projetos de recuperação de áreas degradadas que não possuíam a visão integrada sobre as características 
do ambiente, a correta utilização das informações geológicas e geotécnicas e um sistema de drenagem adequado, apresentaram falhas graves e até o reaparecimento de processos erosivos.

A metodologia e os objetivos de obras de drenagem têm se baseado no recolhimento de volumes de águas pluviais que possam causar prejuízos ou erosões. Em relação às voçorocas, tanto urbanas quanto rurais, por se encontrarem em pequenas bacias hidrográficas, utilizam-se os dados pluviométricos para dimensionamento das estruturas de controle hidráulico; entretanto, em grande parte do Brasil estas informações ou são escassas, ou onde se encontram elevadas quantidades de estações pluviográficas, não são tratadas de forma sistemática, o que dificulta sua utilização (FENDRICH et al., 1997).

Nos casos onde não se encontram estações as quais se possa entrar em contato, é possível obter informações hidrometeorológicas brasileiras através da disponibilização por órgãos como a Agência Nacional de Águas (ANA), o Instituto Nacional de Meteorologia (INMET), o Instituto Nacional de Pesquisas Espaciais (INPE), dentre outros. Porém, devido a problemas em equipamentos ou com os operadores que fazem a leitura dos dados, como a presença de vegetação ou obstrução no posto de observação ou danos aos aparelhos, podem ocorrer algumas falhas nos dados pluviométricos, sendo necessária a utilização de métodos para preenchimento destas (BERTONI; TUCCI, 2001). Existem métodos que visam preencher estas falhas, como o da ponderação regional, regressão linear, ponderação regional com base em regressões lineares e vetor regional (BERTONI; TUCCI, 2001; OLIVEIRA et al., 2010; CALDEIRA; ARAÚJO; BESKOW, 2011), sendo possível melhorar os resultados obtidos pela combinação destes métodos em alguns casos (OLIVEIRA et al., 2010).

Por ser determinante principal de alguns fenômenos como inundações ou erosão, a compreensão da intensidade, duração, frequência e distribuição das chuvas e como podem se comportar seus escoamentos é imprescindível para um projeto que envolva obras de drenagem, assim como as dimensões e características das bacias contribuintes, declividades das encostas, e a caracterização de solos no local (MICHELIN, 1975; FENDRICH, 1998; TUCCI, 2001), pois, no momento em que se recolhe e disciplina o escoamento, são reduzidas as possibilidades de que se desenvolvam mais processos erosivos (PONTES, 1980).

Em geral utiliza-se uma equação que faça uma aproximação do comportamento combinado entre a intensidade, duração e frequência de chuvas intensas de uma dada região, 
chamada equação IDF (Equação 1), podendo-se ser empírica (FENDRICH, 1998; SILVEIRA, 2010).

$$
i=\frac{K \cdot T_{r}^{m}}{\left(t+t_{o}\right)^{n}} \quad \boldsymbol{E} \boldsymbol{q} \cdot(\mathbf{1})
$$

Sendo $i$ a intensidade da chuva máxima em mm. $\mathrm{h}^{-1}, T_{r}$ o período de retorno em anos, $t$ a duração da chuva em minutos, e os parâmetros $K, t_{o}, m$ e $n$ encontrados para a determinada área ou estação de medição (FENDRICH, 1998).

Para isto, realiza-se um estudo com variações dos parâmetros destas equações utilizando-se condições locais para se obter uma aproximação deste comportamento, como por exemplo, fixam-se valores para o tempo de duração da chuva para obter-se a variação da precipitação em função da intensidade e dos períodos de retorno fixados. Após este tratamento dos dados pode-se obter a equação $I D F$, que servirá como base para a elaboração de curvas em um gráfico característico para cada localidade (FENDRICH, 1998; TUCCI, 2001; EVANGELISTA; CARVALHO; BERNARDINO, 2005; DAMÉ et al., 2010; SILVEIRA, 2010).

O tempo de recorrência ou período de retorno, $T_{r}$, é definido pela relação entre o número de anos de observação de chuvas, $m$, e o número de ordem que a precipitação considerada ocupa numa série de precipitações dispostas em ordem de magnitude decrescente, $n$ (Equação 2), sendo este chamado de Método Califórnia (MICHELIN, 1975, FENDRICH et al., 1997).

$$
T_{r}=\frac{m}{n} \quad \boldsymbol{E q} \cdot(2)
$$

Ainda, o período de retorno pode ter sua definição ligada com o valor esperado, em média, do intervalo entre dois eventos críticos que possam provocar a falha de uma obra, e que, para eventos independentes, esse período equivale ao inverso da probabilidade, $P$, de se ter ao menos uma precipitação de intensidade igual ou superior a um dado valor de 
intensidade em um ano qualquer (CHOW et al., 1988 apud FRANCO, 2004; FENDRICH et al., 1997), representado pela Equação (3).

$$
T_{r}=\frac{1}{P}
$$

Usualmente, o período de retorno para uma obra de drenagem é recomendado de acordo com o tipo de ocupação da área e a escala da obra (FENDRICH et al., 1997), como apresentado pela Tabela 2.

Tabela 2 - Período de retorno para diferentes ocupações da área. (PORTO, 1995 apud SILVEIRA, 2010).

Tipo de Obra

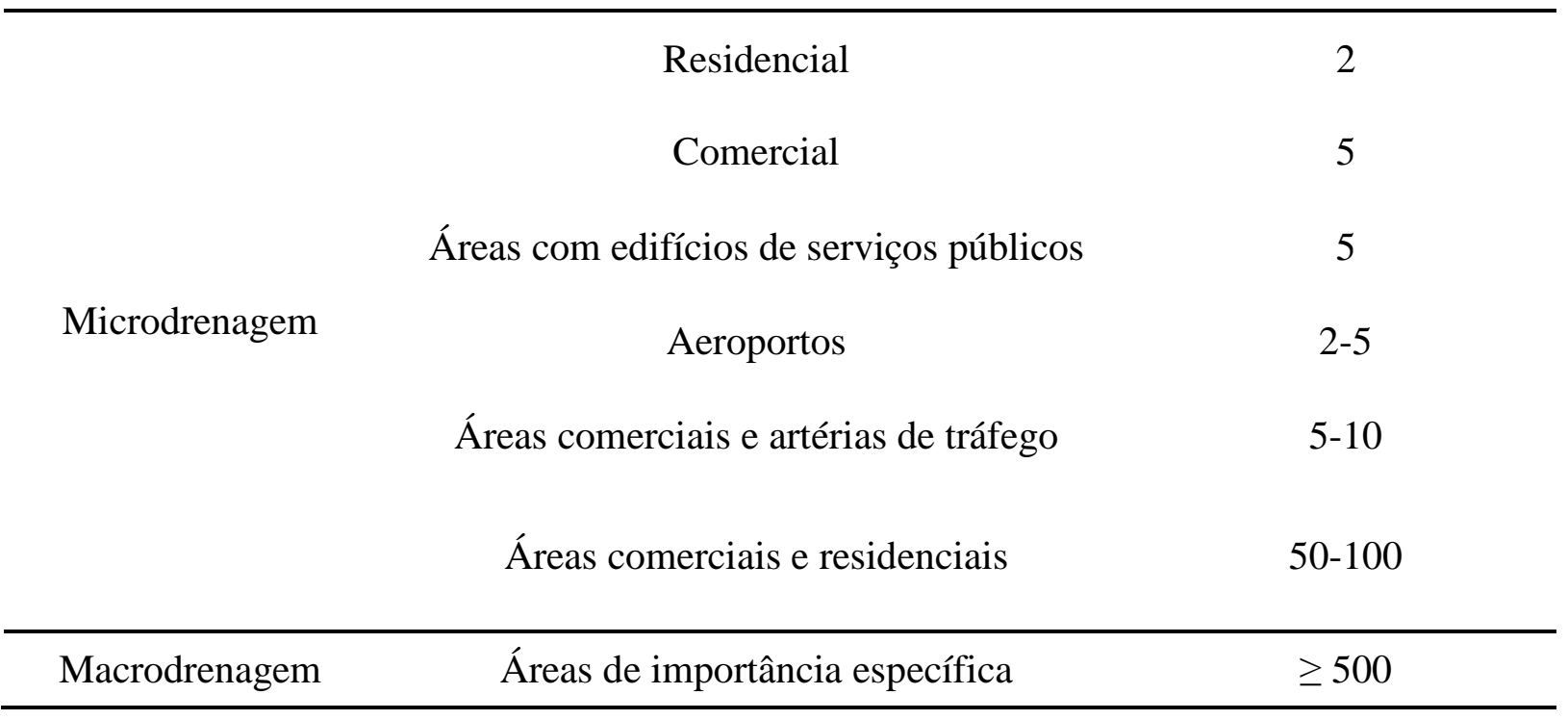

A concepção de um projeto de drenagem superficial deve abarcar a noção de que os condutos terão sua capacidade superada em 5, 10 ou mais anos, em média. Assim, realiza-se um balanço econômico entre a média anual prevista dos prejuízos devidos a inundações e custos de estruturas de maior capacidade a serem inclusas (WILKEN, 1978).

A água precipitada que alimenta parte ou totalmente o escoamento superficial se encontra em uma bacia de contribuição ou de drenagem, peça fundamental para o 
planejamento de um sistema de drenagem; esta bacia é limitada pelos divisores de água ou espigões, que irão separá-la das outras bacias, e irá conduzir a água a um único ponto final, denominado exutório; o tempo de concentração é definido como o tempo, em minutos, que uma gota d'água teoricamente demora no percurso do ponto mais afastado ao exutório da bacia contribuinte (WILKEN, 1978; FENDRICH et al., 1997). O estudo das características físicas da bacia, além das características climáticas, é de suma importância para o entendimento das propriedades hidráulicas dos canais de drenagem (WILKEN, 1978; FRANCO, 2004), sendo estas:

- Área da bacia: traça-se os divisores de água da bacia contribuinte em planta topográfica, sendo indicado para bacias urbanas a escala de 1:2.000, para estudos mais detalhados, ou de 1:5.000. Para bacias compreendendo áreas rurais a escala de 1:10.000 pode ser suficiente;

- Declividade do curso d'água: determinam-se os perfis longitudinais do fundo de vale principal e dos secundários, representados em plano onde o eixo das abscissas mostra o comprimento do leito e as ordenadas apresentam a altura do fundo;

- Declividade da bacia: o relevo da bacia contribuinte é um fator determinante de formação das cheias, podendo influenciar processos erosivos, regimes hidráulicos e infiltração, e traz informações sobre a velocidade de escoamento e perdas d'água. A declividade média da bacia pode ser calculada através das curvas de nível;

- Geomorfologia: a compreensão das características geomorfológicas da bacia é importante no sentido de que se visualiza a estrutura da região, a causa dos aspectos atuais e a ideia do que existia anteriormente. Além da descrição qualitativa, a aquisição de dados quantitativos auxilia a obtenção de soluções para problemas hidráulicos;

- Geologia: com este conhecimento, se tem noção do comportamento do solo e rochas em relação às características físico-hídricas e de permeabilidade do local de estudo;

- Cobertura vegetal: a existência de cobertura densa pode reduzir o escoamento superficial e proteger o solo de compactação;

- Uso e ocupação: a atividade antrópica altera as condições físicas do solo, como compactação e impermeabilização, devendo-se dividir a bacia em área urbana, 
suburbana e rural, ou outras características consideradas relevantes, como tipo de cultura, por exemplo.

Para se estimar a vazão e o volume de escoamento superficial é possível utilizar vários métodos. Existem os métodos baseados em fórmulas empíricas (como a de Kresnik ou a de Fuller), os métodos estatísticos (curvas de probabilidade e ajustamento matemático) e os métodos com fundamento cinemático (Racional, Racional Melhorado - Improved Rational Hydrograph, Italiano Paladini-Fantoli, métodos gráficos alemães, Hidrograma Unitário, Iteração, Santa Bárbara) (WILKEN, 1978; FENDRICH et al., 1997, THOMPSON, 2006; CROBEDDU et al., 2007; SILVEIRA, 2010). A escolha do método a ser utilizado depende, basicamente, de critérios como: o tamanho da área de contribuição, a disponibilidade de dados de entrada e o comportamento da chuva e do escoamento a ser considerado.

Um método muito utilizado é o método SCS-CN (Soil Conservation Service - Curve Number), criado pelo U.S. Soil Conservation Service (SCS) do Departamento de Agricultura dos Estados Unidos. Conceitualmente, o método SCS-CN baseia-se na condição de que a precipitação total que cai sobre uma área irá gerar o volume de escoamento superficial após a consideração de perdas, denominadas abstrações iniciais, como a interceptação de vegetação ou obstáculos, a infiltração e o armazenamento (STONE; RENARD; LANE, 1996). Este volume de escoamento pode ser representado pela área do hidrograma de formato triangular gerado (SCS, 1972 apud SILVEIRA, 2010).

A precipitação, infiltração e escoamento superficial são associados conforme exibe a Equação (4) (STONE; RENARD; LANE, 1996):

$$
Q=\frac{\left(R-I_{a}\right)^{2}}{R-I_{a}+S} \quad \text { Eq. (4) }
$$

$\mathrm{Na}$ Equação (4), o escoamento superficial é dado por $Q$, a precipitação é dada por $R$, a abstração inicial é $I_{a}$, e as perdas potenciais máximas que podem ocorrer após o início do escoamento, somadas à abstração inicial são dadas por $S$. Após alguns estudos realizados em bacias rurais pequenas nos Estados Unidos, foi possível chegar a uma relação entre a abstração inicial $I_{a}$ e as perdas $S$ (STONE; RENARD; LANE, 1996) apresentada na Equação (5). 


$$
I_{a}=0,2 . S
$$

A Equação (5), utilizada na Equação (4), provê as Equações (6), (7) e (8), apresentadas a seguir, as quais inserem o conceito e o valor do número da curva ( $\mathrm{CN}-\mathrm{Curve}$ Number) (STONE; RENARD; LANE, 1996).

$$
\begin{array}{ll}
Q=\frac{(R-0,2 . S)^{2}}{R+0,8 S} \text { para } \mathrm{R}>0,2 . S & \boldsymbol{E} \boldsymbol{q} \cdot(\mathbf{6}) \\
Q & =0 \text { para } \mathrm{R} \leq 0,2 . \mathrm{S}
\end{array}
$$

É importante atentar que a relação dada para o país norte americano na Equação (5) nem sempre pode ser utilizada para todas as áreas. Shi et al. (2009) realizaram estudo para verificar a relação entre a abstração inicial e perdas potenciais em uma bacia rural na China (Província de Hubei, região dos Três Desfiladeiros), encontrando o valor médio de 0,052 com melhor eficiência para esta relação que o valor de 0,2 proposto anteriormente.

$\mathrm{O}$ valor de $C N$ pode ser obtido através da média de coeficientes estimados para do uso, tratamento, condições hidrológicas e condições de umidade do solo (precipitações ocorridas em 5 dias antecedentes), e tipo de solo e seu grupo hidrológico. Os valores destes coeficientes foram estimados e organizados inicialmente pelo Departamento de Agricultura dos Estados Unidos, sendo alguns apresentados nas Tabelas 3 e 4 (PONCE; HAWKINS, 1986 apud SILVEIRA, 2010; STONE; RENARD; LANE, 1996). 
Tabela 3 - Os quatro grupos hidrológicos de solo do SCS (Adaptada de PORTO, 1995).

\begin{tabular}{|c|c|}
\hline Grupos & Definição \\
\hline $\mathbf{A}$ & $\begin{array}{l}\text { Solos arenosos com baixo teor de argila total, inferior a } 8 \% \text {, não } \\
\text { há rocha nem camadas argilosas e nem mesmo densificadas até a } \\
\text { profundidade de } 1,5 \mathrm{~m} \text {. O teor de húmus é muito baixo, não } \\
\text { atingindo } 1 \% \text {. }\end{array}$ \\
\hline B & $\begin{array}{l}\text { Solos arenosos menos profundos que os do Grupo A e com menor } \\
\text { teor de argila total, porém ainda inferior a } 15 \% \text {. No caso de terras } \\
\text { roxas este limite pode subir a } 20 \% \text { graças a maior porosidade. Os } \\
\text { dois teores de húmus podem subir, respectivamente, a } 1,2 \text { e } 1,5 \% \text {. } \\
\text { Não pode haver pedras nem camadas argilosas até } 1,5 \mathrm{~m} \text {, mas } \\
\text { quase sempre presente camada mais densificada que a camada } \\
\text { superficial. }\end{array}$ \\
\hline $\mathbf{C}$ & $\begin{array}{l}\text { Solos barrentos com teor total de argila de } 20 \% \text { a } 30 \% \text { mas sem } \\
\text { camadas argilosas impermeáveis ou contendo pedras até } \\
\text { profundidades de } 1,2 \mathrm{~m} \text {. No caso de terras roxas, estes dois limites } \\
\text { máximos podem ser } 40 \% \text { e } 1,5 \mathrm{~m} \text {. Nota-se a cerca de } 60 \mathrm{~cm} \text { de } \\
\text { profundidade camada mais densificada que no Grupo B, mas ainda } \\
\text { longe das condições de impermeabilidade. }\end{array}$ \\
\hline D & $\begin{array}{l}\text { Solos argilosos }(30-40 \% \text { de argila total }) \text { e ainda com camada } \\
\text { densificada a uns } 50 \mathrm{~cm} \text { de profundidade. Ou solos arenosos como } \\
\mathrm{B} \text {, mas com camada argilosa quase impermeável, ou horizonte de } \\
\text { seixos rolados. }\end{array}$ \\
\hline
\end{tabular}


Tabela 4 - $C N$ de escoamentos superficiais para coberturas complexas dos tipos hidrológicos do solo sob condições médias de antecedentes de umidade (Adaptada de SCS, 1972 apud STONE; RENARD; LANE, 1996).

\begin{tabular}{|c|c|c|c|c|c|c|}
\hline \multirow{2}{*}{ Uso da Terra } & \multirow{2}{*}{ Cobertura } & \multirow{2}{*}{$\begin{array}{c}\text { Condição } \\
\text { Hidrológica }\end{array}$} & \multicolumn{4}{|c|}{ Grupo Hidrológico do Solo } \\
\hline & & & $\mathbf{A}$ & $\mathbf{B}$ & $\mathbf{C}$ & D \\
\hline $\begin{array}{c}\text { Terra } \\
\text { cultivada } \\
\text { deixada em } \\
\text { descanso }\end{array}$ & Linha reta & & 77 & 86 & 91 & 94 \\
\hline \multirow{6}{*}{$\begin{array}{l}\text { Cultura em } \\
\text { linhas }\end{array}$} & Linha reta & Pobre & 72 & 81 & 88 & 91 \\
\hline & Linha reta & Boa & 67 & 78 & 85 & 89 \\
\hline & Curva & Pobre & 70 & 79 & 84 & 88 \\
\hline & Curva & Boa & 65 & 75 & 82 & 86 \\
\hline & Curva com terraço & Pobre & 66 & 74 & 80 & 82 \\
\hline & Curva com terraço & Boa & 62 & 71 & 78 & 81 \\
\hline \multirow{6}{*}{$\begin{array}{c}\text { Grãos } \\
\text { pequenos }\end{array}$} & Linha reta & Pobre & 65 & 76 & 84 & 88 \\
\hline & Linha reta & Boa & 63 & 75 & 83 & 78 \\
\hline & Curva & Pobre & 63 & 74 & 82 & 85 \\
\hline & Curva & Boa & 61 & 73 & 81 & 84 \\
\hline & Curva com terraço & Pobre & 61 & 72 & 79 & 82 \\
\hline & Curva com terraço & Boa & 59 & 70 & 78 & 81 \\
\hline \multirow{6}{*}{$\begin{array}{l}\text { Legumes ou } \\
\text { campo de } \\
\text { rotação }\end{array}$} & Linha reta & Pobre & 66 & 77 & 85 & 89 \\
\hline & Linha reta & Boa & 58 & 72 & 81 & 85 \\
\hline & Curva & Pobre & 64 & 72 & 83 & 85 \\
\hline & Curva & Boa & 55 & 69 & 78 & 83 \\
\hline & Curva com terraço & Pobre & 63 & 73 & 80 & 83 \\
\hline & Curva com terraço & Boa & 51 & 67 & 76 & 80 \\
\hline \multirow{6}{*}{$\begin{array}{l}\text { Pasto ou } \\
\text { intervalo }\end{array}$} & & Pobre & 68 & 79 & 86 & 89 \\
\hline & & Regular & 49 & 69 & 79 & 84 \\
\hline & & Boa & 69 & 61 & 74 & 80 \\
\hline & Curva & Pobre & 47 & 67 & 81 & 88 \\
\hline & Curva & Regular & 25 & 59 & 75 & 83 \\
\hline & Curva & Boa & 6 & 35 & 70 & 79 \\
\hline Campo & & Boa & 30 & 58 & 71 & 78 \\
\hline \multirow{3}{*}{ Floresta } & & Pobre & 45 & 66 & 77 & 83 \\
\hline & & Regular & 36 & 60 & 73 & 79 \\
\hline & & Boa & 25 & 55 & 70 & 77 \\
\hline Fazendas & & & 59 & 74 & 70 & 77 \\
\hline \multirow[b]{2}{*}{ Rodovias } & Barrenta & & 72 & 82 & 78 & 89 \\
\hline & Superfície dura & & 74 & 84 & 90 & 92 \\
\hline
\end{tabular}


Existem, ainda, algumas metodologias que possuem a função de auxiliar a tomada de decisões, denominadas de Sistemas de Suporte a Decisões (SSD); baseando-se na reunião de vários métodos passíveis de serem utilizados para o estudo dos hidrogramas e do comportamento do escoamento em uma bacia hidrográfica, como o $S C S-C N$ supracitado, e utilizando-se de um ambiente computacional de fácil aplicação, o software ABC (Análise de Bacias Complexas), é proporcionado gratuitamente pelo Laboratório de Sistemas de Suporte a Decisões (LabSid), do Departamento de Engenharia Hidráulica e Sanitária da Escola Politécnica da Universidade de São Paulo (USP) (DAEE, 2005; SILVEIRA, 2010). Utilizando-se o $A B C$ ( 6 , em sua última versão), é possível realizar uma avaliação e planejamento de obras de drenagem para bacias que não possuam dados de origem fluvial (SILVEIRA, 2010).

A partir da escolha do método de previsão da vazão superficial de projeto é possível realizar o planejamento das estruturas que possam disciplinar ou conter este escoamento. Estas estruturas podem ser subdivididas em microdrenagem, que seriam as ligadas ao esgotamento das vazões de precipitações que ocorrem com mais frequência, reduzindo-se, dessa forma, energia do escoamento superficial direto no solo, e macrodrenagem, que têm por finalidade conduzir a água captada pelas estruturas anteriores para continuar o escoamento até um destino final (FENDRICH et al., 1997; FERREIRA, 2004).

Souza (2001) aponta diversos autores que enumeram as obras de microdrenagem como: guias/meio-fio, sarjetas, sarjetões, bocas de lobo, bocas coletoras, galerias, poços de visita, tubos de ligação, coletores; e as de macrodrenagem: canais (naturais ou artificiais), dissipadores de energia (BP, MS, bacia de mergulho), ressaltos hidráulicos, canais abertos, barragens, vertedouros (queda, calha e degrau "cacimbo"), bacias de acumulação, bacias dissipadoras. Ainda, em relação a obras complementares, poderiam ser realizadas obras de proteção de taludes, aterramento, obras de pavimentação, drenos, mapeamento e cartografia geotécnica.

Os canais são obras realizadas para escoar as águas pluviais ou de esgoto, podendo ser abertos ou fechados; os materiais geralmente utilizados para conferir maior estabilidade a eles são cobertura vegetal, concreto, concreto armado, gabiões, alvenaria e material geotêxtil (FERREIRA, 2004; PORTO, 2006). Podem ser associados a outros elementos, como as sarjetas (Figura 8), rápidos (Figura 9) e dissipadores (Figuras 10), dentre outros. Devem ser dimensionados de forma apropriada para cada local; em caso de processos erosivos de 
elevadas profundidades, por exemplo, deveriam ser construídos com distância de 20 a $30 \mathrm{~m}$ da cabeceira da erosão (SOUZA, 2001). Usualmente, a confecção de canais está vinculada à função de drenar outros tipos de obras, como estradas e aterros (DNER, 1996). A Figura 11 apresenta como esta vinculação pode ser realizada.

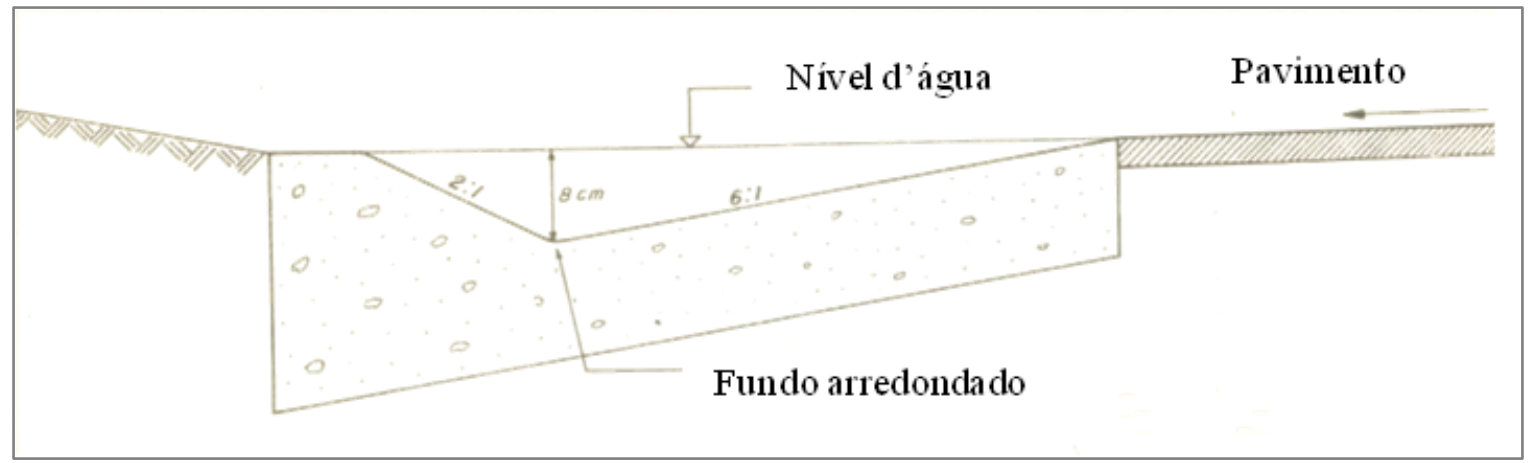

Figura 8 - Sarjeta em depressão rasa. (Modificada de MICHELIN, 1975).

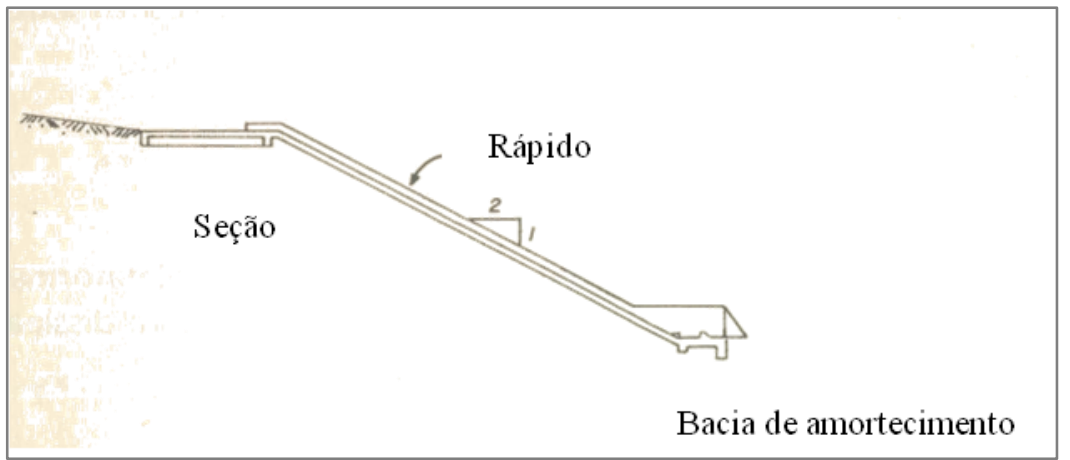

Figura 9 - Rápido. (Modificada de MICHELIN, 1975).

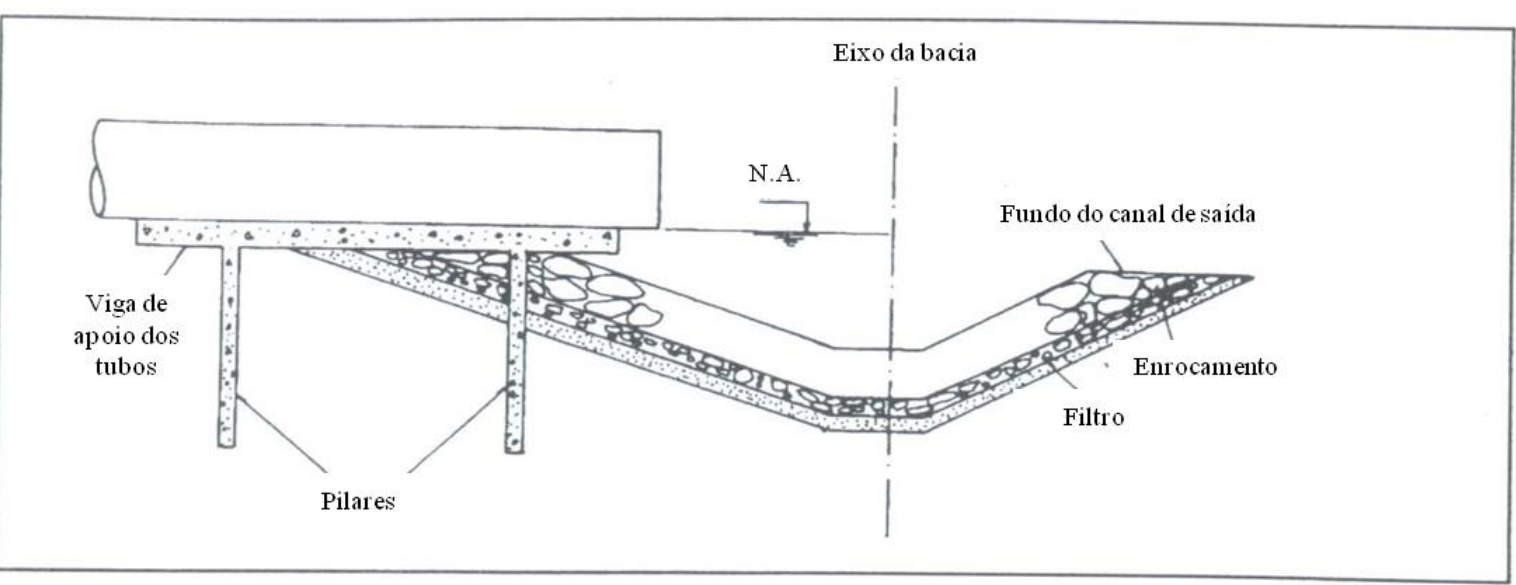

Figura 10 - Bacia de dissipação tipo mergulho em perfil. (PONTES, 1980). 


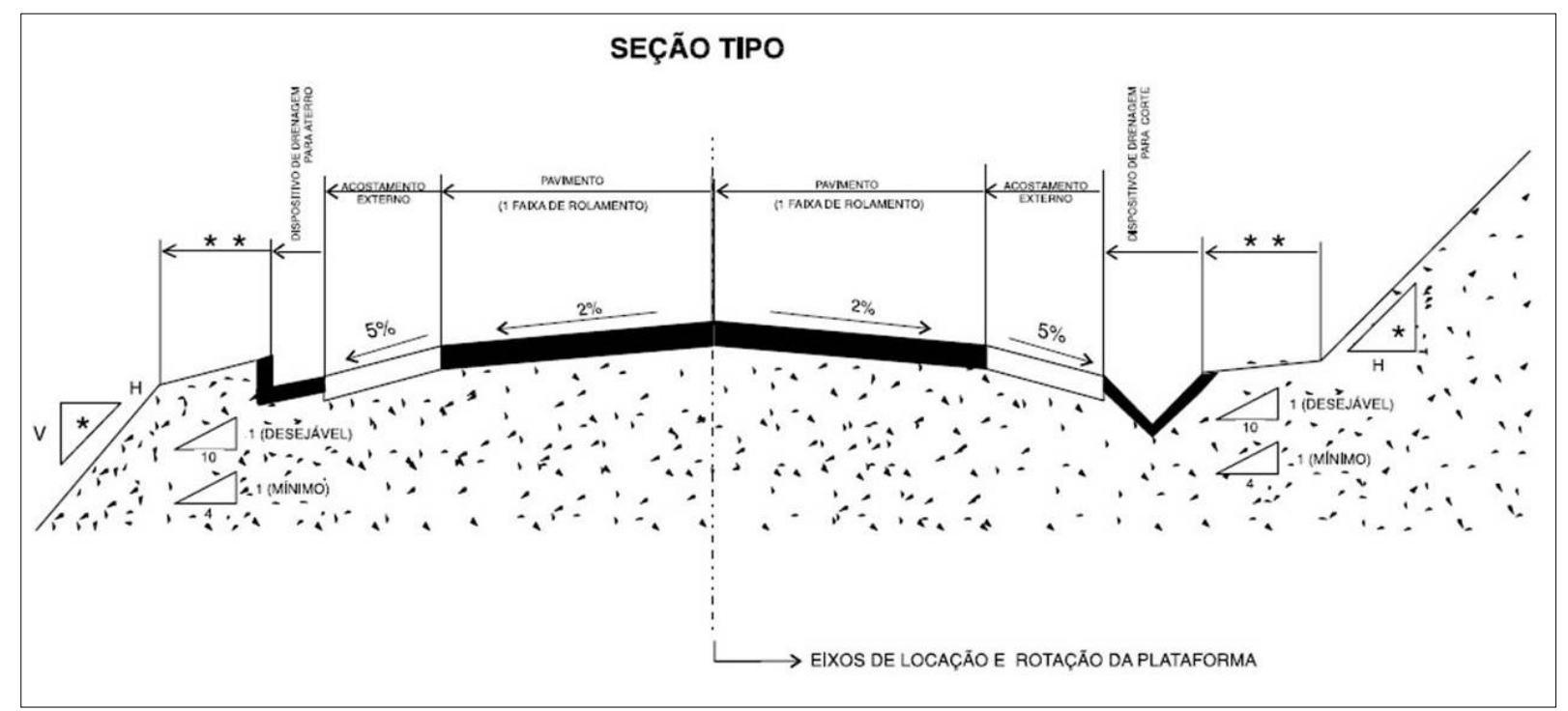

Figura 11 - Características físicas e geométricas de seção transversal de rodovia (Modificada de DNER, 1996).

É importante observar que qualquer implantação de estruturas especiais, como mudanças de declividade, confluências, soleiras, dentre outros, é capaz de adicionar características hidráulicas não previstas no projeto inicial, sendo necessário avaliar como estas estruturas irão alterar a linha de energia e alturas da água no canal (MARTINS, 1995; PORTO, 2006).

Para canais abertos, muitas fórmulas foram propostas para que se encontre a velocidade do escoamento superficial, sendo que, em sua grande maioria, os parâmetros mais importantes que se relacionam com esta velocidade são a inclinação, o raio hidráulico e o coeficiente de rugosidade de fundo e das laterais do canal (LUTHIN, 1973). Algumas fórmulas mais utilizadas são a fórmula de Chezy, o qual considerava que a rugosidade do canal era um valor constante (coeficiente $C$ ), apresentada na Equação (9), e a de Manning, que leva em conta as variações da rugosidade de cada material que se possa construir o canal (coeficiente $n$ ), apresentada na Equação (10) (LUTHIN, 1973; FENDRICH et al., 1997; PORTO, 2006).

$$
\begin{aligned}
& v=C \cdot\left(R_{h} \cdot I\right)^{1 / 2} \\
& v=\left(\frac{1,486}{n}\right) R_{h}{ }^{2 / 3} I^{1 / 2}
\end{aligned}
$$

Sendo $v$ a velocidade do canal, $R_{h}$ é o raio hidráulico (calculado pela relação entre a área da seção e o perímetro molhado), e $I$ é a inclinação do canal. 
Destaca-se que existe uma velocidade limite à qual o fluxo d'água está associado de tal forma que, ultrapassando esta velocidade, o regime de escoamento pode transitar de subcrítico (ou fluvial) para supercrítico (ou torrencial). Uma referência que usualmente é utilizada é o número de Froude (Eq. 11), com o qual observam-se as seguintes relações (PORTO, 2006):

$$
F r=\frac{V}{\sqrt{g \cdot H_{m}}}
$$

- Para Fr < 1, escoamento subcrítico;

- Para Fr > 1, escoamento supercrítico;

- Para Fr = 1, escoamento crítico.

Em que $V$ é a velocidade do escoamento, $g$ é a aceleração da gravidade, e $H_{m}$ é a altura hidráulica, relação entre a área molhada e a largura da seção.

Para os casos em que se queira compreender as dimensões e influências que a elaboração de canais possa acarretar, é possível também se utilizar de softwares de ambiente amigável associando-se como complementação do projeto, como o Canal, criado pelo Grupo de Pesquisa em Recursos Hídricos (GPRH) da Universidade Federal de Viçosa, os desenvolvidos pelo professor Rodrigo de Melo Porto, no Departamento de Hidráulica e Saneamento da Escola de Engenharia de São Carlos, o SWMM (Storm Water Management Model), da U.S. Environmental Protection Agency (U.S. EPA), ou adquiridos gratuitamente em ambientes da internet como engenhariacivil.com, ou tantos outros disponíveis nas Universidades e Centros de Pesquisa (GPRH, SHS, LENHS e CIVILNET, 2014).

Considerando-se à água subsuperficial, Sen (1995) enumera que as formas de se encontrá-la estão divididas de acordo com sua ocorrência física e a pressão no meio. A Figura 12 ilustra esta divisão, em que se considera como zona saturada a parte em que todos os poros do maciço de solo estão ocupados por água a uma pressão maior que a atmosférica. 


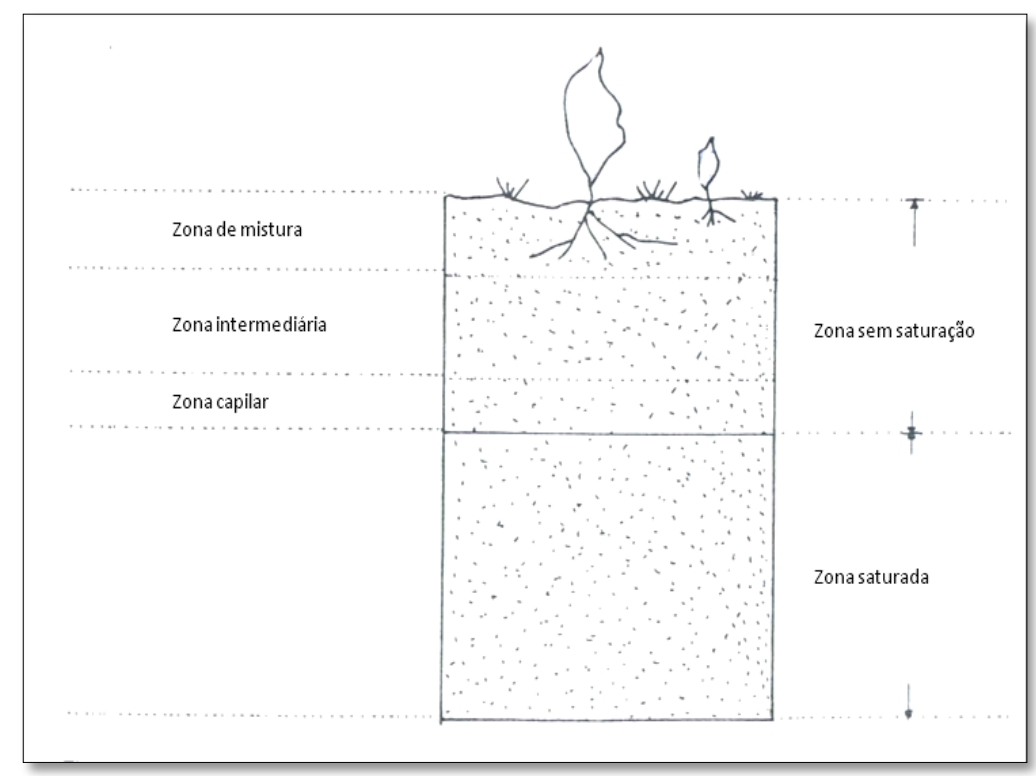

Figura 12 - Zonas da água na litosfera. (Adaptada de SEN, 1995).

A zona não saturada ou vadosa é a porção acima da saturada, onde os vazios podem estar preenchidos por uma mistura entre ar, água e outras substâncias, sendo a pressão nesta zona menor que a atmosférica. Esta parte ainda pode ser subdividida entre: franja capilar, na qual a água contida é parte da zona saturada e da vadosa, e está presa aos interstícios pela ação das forças de capilaridade contra as da gravidade; zona de mistura do solo, na qual a movimentação da água depende das condições do local, e sua espessura varia de acordo com o clima e tipo de solo, sendo esta a parte que contém as características necessárias às plantas para sua sobrevivência. Ainda, denomina-se nível d'água a parte entre a zona saturada e não saturada que se encontra com pressão igual à atmosférica (SEN, 1995). A água que se encontra no solo, ao preencher seus poros, pode impedir que ocorra a troca de gases e limitar a presença de oxigênio em seu interior; dessa maneira, se torna necessária a realização da drenagem desta água, quando em excesso, para que haja o estabelecimento e desenvolvimento das raízes das plantas em um ambiente ótimo (LUTHIN, 1973).

Para se realizar um projeto com a finalidade de se drenar a água subsuperficial é necessário: que se conheçam as características granulométricas dos solos que constituem os horizontes no perfil até, aproximadamente, $1,50 \mathrm{~m}$ de profundidade; que se determine o nível d'água subterrâneo e fontes de água aflorantes; e ainda, que se obtenham as características da granulometria de cascalhos e areias que podem se encontrar na região com a finalidade de, caso necessário, serem utilizadas nos drenos (MICHELIN, 1975). 
A infiltração da água no solo pode ser medida através de anéis denominados infiltrômetros (DANIEL, 1994), ou ainda, através de métodos que aproximem os índices de infiltração razoavelmente, como o índice $\varphi$, definido como a intensidade média de precipitação acima da qual o volume de chuva se iguala ao volume de escoamento superficial, e o $W$, definido como a taxa de infiltração média durante o período em que a intensidade de chuva excede a capacidade de infiltração, e segue a Equação (12) e a Figura 13 (WILKEN, 1978):

$$
W=\frac{F_{i}}{T}=\frac{1}{T}\left(P-Q_{S}-S_{e}\right)
$$

Sendo $F_{i}$ a quantidade total de água infiltrada, $T$ o tempo em que a intensidade de chuva excede a capacidade de infiltração, $P$ a precipitação, $Q_{s}$ o escoamento superficial verificado com a chuva, e $S_{e}$ a detenção superficial total.

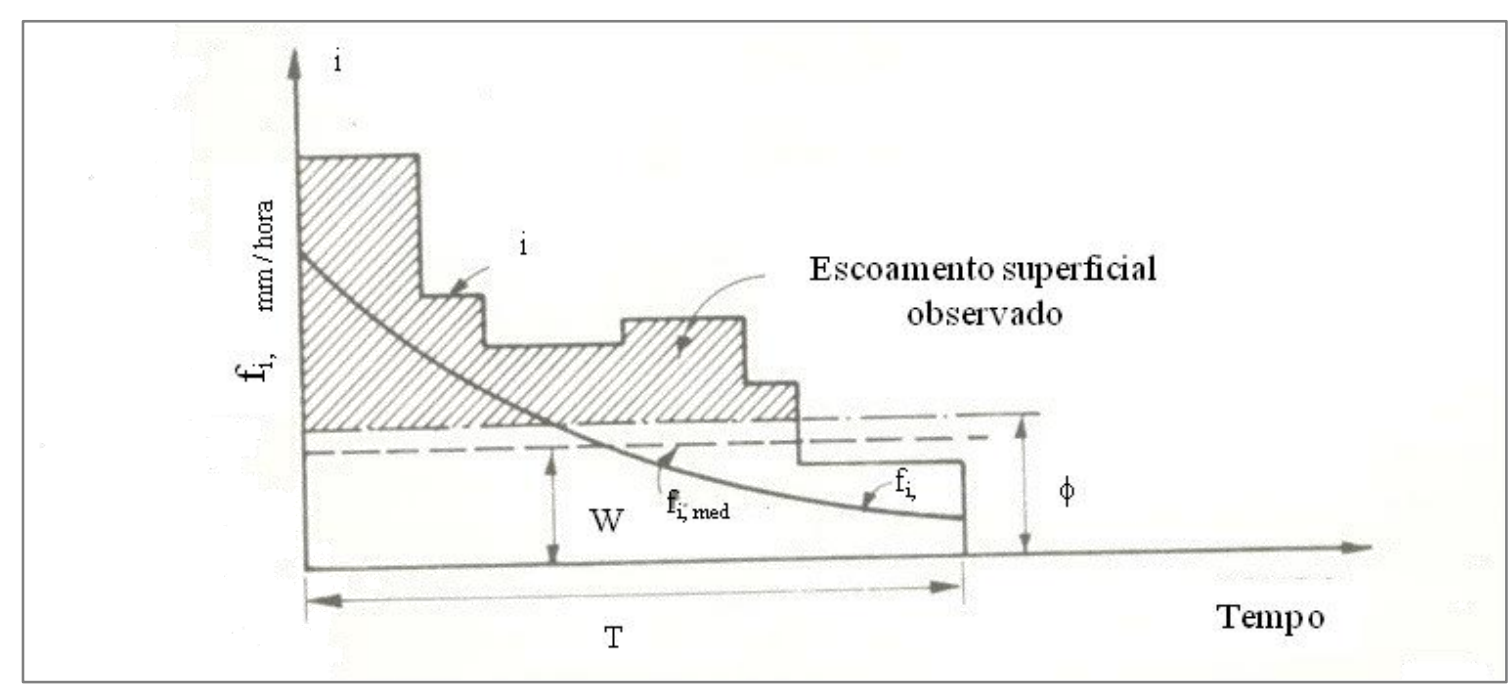

Figura 13 - Quantidade total de água infiltrada em relação ao tempo (WILKEN, 1978).

É possível, também, obter uma estimativa do comportamento da permeabilidade da água em solos através de alguns ensaios em laboratório, como os ensaios de condutividade hidráulica a carga constante ou variável com permeâmetros de paredes fixas ou flexíveis; cabe ressaltar que, devido às diferenças de escala, dos tipos e características dos solos e das condições climáticas, os dados obtidos em laboratório podem subestimar os valores obtidos com ensaios in situ (BENSON; HARDIANTO; MOTAN, 1994). 
Quando o processo erosivo atinge o nível do lençol freático os mecanismos se intensificam, principalmente a partir da percolação lenta junto à parede da voçoroca e da liquefação do material granular; estes processos reduzem a coesão do solo e tomam como consequência o solapamento dos taludes. Diante disto, o disciplinamento da água subsuperficial é considerado mais difícil que o da água superficial (DAEE/IPT, 1989).

Este disciplinamento pode ser realizado através de drenos subterrâneos longitudinais enterrados, os quais se constituem em valas construídas paralelamente ao eixo de pavimentos ou canais, com a inserção de um tubo perfurado para a drenagem e assentado no fundo, preenchidos com material permeável (considerados contínuos quando colocado um tipo filtrante somente, e descontínuos, quando colocados filtrantes e drenantes) sendo que deve ser selado em seu topo com material impermeável. Deve-se atentar para que sua construção não seja realizada junto ao talude, pois isto pode causar seu deslizamento, sendo recomendado para voçorocas, disporem-se os drenos de forma a se ramificarem a partir de um eixo central como aponta a Figura 14 (MICHELIN, 1975; EMBRAPA, 2011).

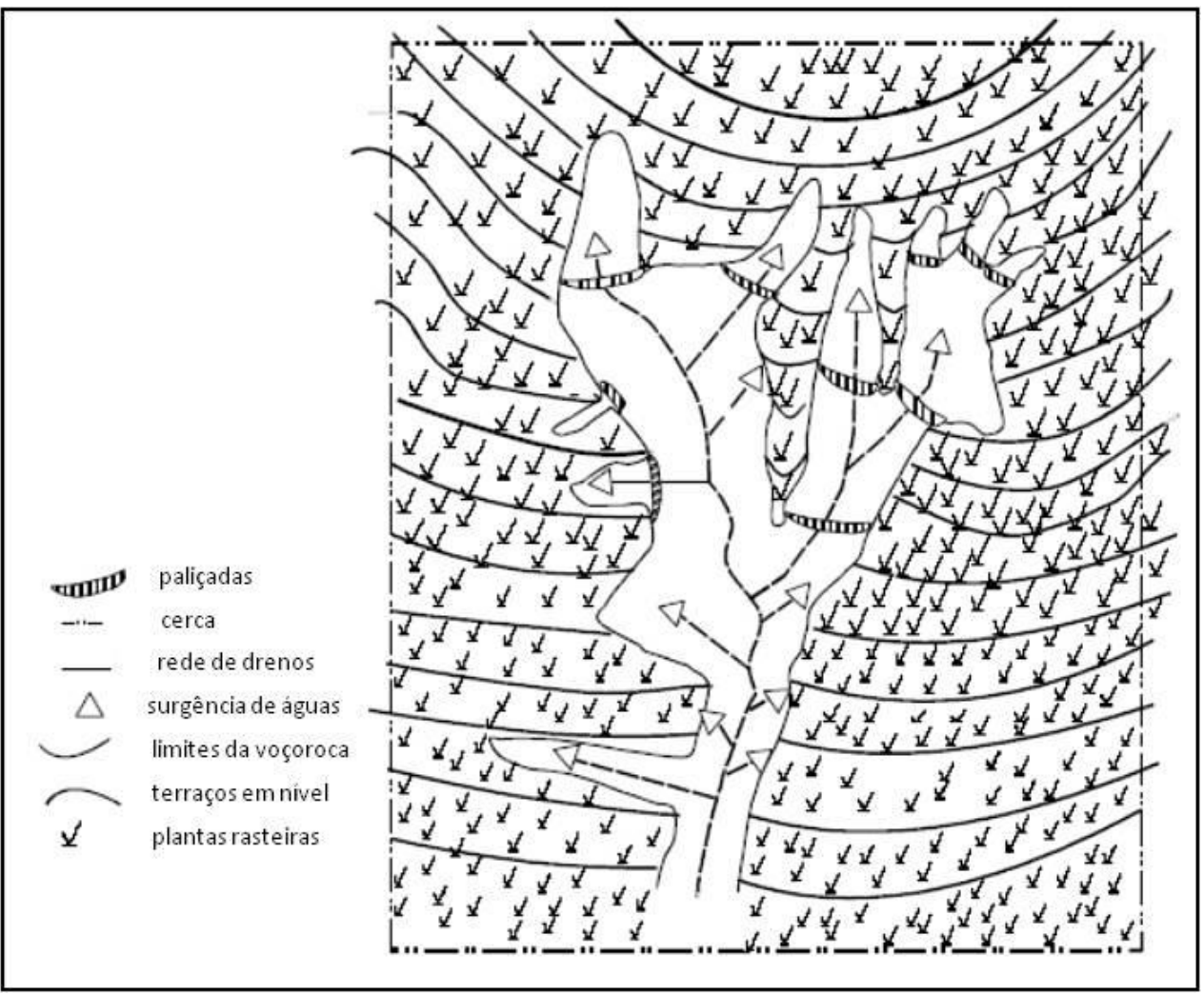

Figura 14 - Esquema mostrando algumas obras/medidas necessárias para contenção de uma voçoroca (EMBRAPA, 2011). 
Para implantação dos drenos subsuperficiais podem ser utilizados diferentes materiais, como geotêxteis ou bambu, por exemplo, sendo que sua conformação pode apresentar as características exibidas nas Figuras 15 e 16 (DAEE/IPT, 1989; EMBRAPA, 2011).

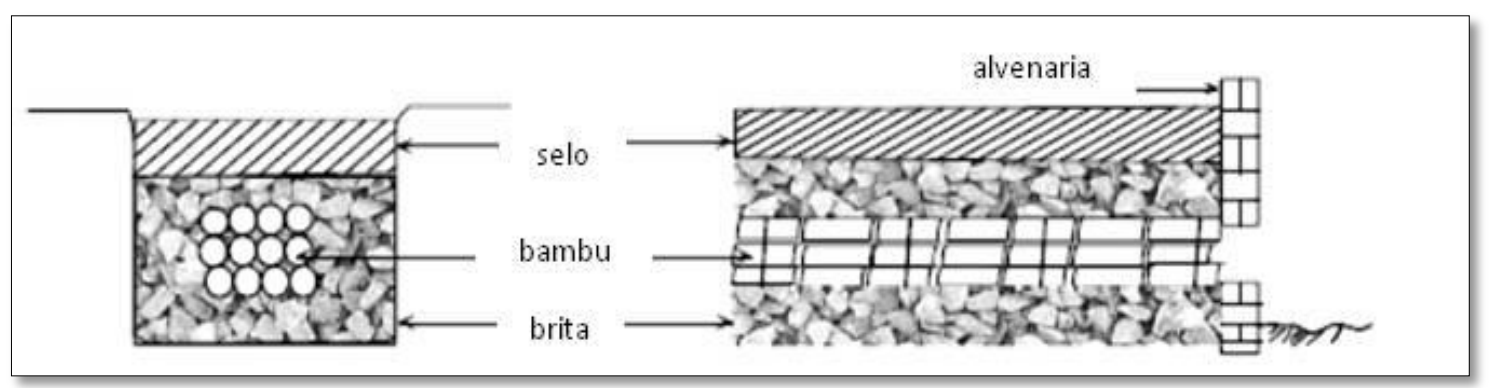

Figura 15 - Dreno de bambu, composto de brita e bambus amarrados em feixes, recobertos por material impermeável (selo). (DAEE/IPT, 1989; EMBRAPA, 2011).

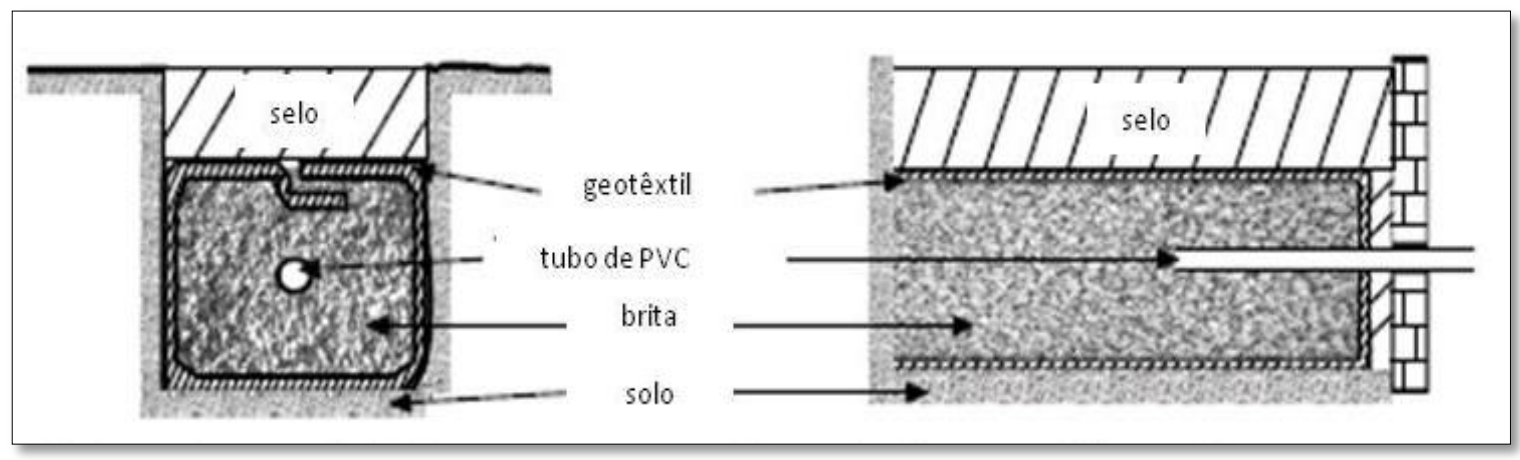

Figura 16 - Dreno de geotêxtil, composto por manta geotêxtil preenchida por brita. (DAEE/IPT, 1989; EMBRAPA, 2011).

Podem ainda ser realizados drenos subterrâneos transversais, drenos em sistemas de camadas, drenos horizontais profundos (DHP), dentre outros. Em quaisquer casos de dimensionamento da drenagem subterrânea, é necessário estudar as condições hidrogeológicas locais, estimando-se o fluxo da água e a vazão que precisa ser drenada (OLIVEIRA, 1982; VALENTE, 1988; CAMPOS, 2003), para posteriormente, consideraremse os custos de instalação das obras diante da eficiência do sistema projetado.

\subsection{Sistemas de Informação Geográfica (SIG)}

Um ambiente computacional que possa reunir instrumentos para armazenar, tratar, operar, combinar e apresentar informações com uma referência espacial pode ser denominado 
de Sistema de Informação Geográfica ou Sistema de Informação Georreferenciada (SIG) (PETERSEN; NIZEYIMANA; EVANS, 1998).

A utilização de SIG é uma importante ferramenta, tanto na compreensão prévia das características ambientais do local de estudo, quanto na manipulação e criação de informações que possam agregar conhecimento novos, como visto por Grissinger (1996a e b), Petersen, Nizeyimana e Evans (1998), Simão Junior (2001), Yamanouth (2003), Malczewski (2004), Pedro e Lorandi (2004), Silva (2006), Bernasconi, Mendonça e Micol (2009), Araújo (2011), Gimenes e Augusto Filho (2013), Magri (2013) e Sampaio et al. (2013). Faz-se de excelente utilidade à medida que exerce o papel da interdisciplinaridade na união do grande volume de informações que são obtidos nas diferentes linhas científicas, sendo considerada imprescindível ao planejamento de forma holística na recuperação de áreas degradadas (SIMÃO JUNIOR, 2001).

O Modelo Digital de Terreno (MDT) ou Modelo Digital de Elevação (MDE) é muito utilizado como ferramenta de construção, análise e extração de informações de sub-bacias em SIG, como a topografia, volumes, áreas, declividades, representação de perfis e de perspectivas tridimensionais; também, através da combinação de dados como as características da rede de drenagem, o índice de sinuosidade, densidade de drenagem, locais de acumulação de água, direção de fluxo, dentre outros, pode-se compreender o desenvolvimento de processos erosivos (BURROUGH, 1989 apud PETERSEN; NIZEYIMANA; EVANS, 1998; ARAUJO e SILVA, 2011).

Extremamente utilizada é a conjunção de ambientes de SIG com outros modelos de simulação, como Water Erosion Prediction Project (WEPP, 2014) e Soil and Water Assessment Tool (SWAT, 2014), os quais podem auxiliar em análises de dados, compreensão e previsão dos processos erosivos e perdas de solo tanto em pequenas áreas como para escala de bacias hidrográficas (GRISSINGER, 1996a). É possível estudar os efeitos de uma atividade de recuperação de áreas degradadas e os ocorridos off site após sua implantação, a partir da integração dos dados da bacia e das respostas dos modelos numéricos de simulação, como forma de complementar a análise global das alterações pertinentes às influências destas atividades (GRISSINGER, 1996b).

A despeito das vantagens apresentadas, é necessário destacar que a utilização das informações obtidas com SIG em campo pode ser custosa e sua viabilidade deve ser 
analisada, assim como é importante atentar para o fato de que a utilização de softwares desses sistemas podem carregar erros, como aqueles ocorridos devido às aproximações realizadas na digitalização das informações, às escalas utilizadas e à compatibilidade destes dados com os reais observados em campo (PETERSEN; NIZEYIMANA; EVANS, 1998).

\section{CARACTERIZAÇÃO DA ÁREA}

\subsection{Localização e Acesso}

A área de estudo está localizada na porção sul do estado de Minas Gerais, município de Nazareno, como apresentado na Figura 17. Este município faz limite com Ibituruna, Bom Sucesso, São Tiago, Conceição da Barra de Minas, São João Del Rei, Carrancas e Itutinga.

O acesso à Nazareno pode ser realizado pela BR-381 (Rodovia Fernão Dias), a partir de Três Corações; chegando-se em Lavras, o acesso é realizado pela BR-265 no sentido de São João Del Rei. No trevo após a represa de Itutinga, entra-se à esquerda na MG-332, em direção à Nazareno.

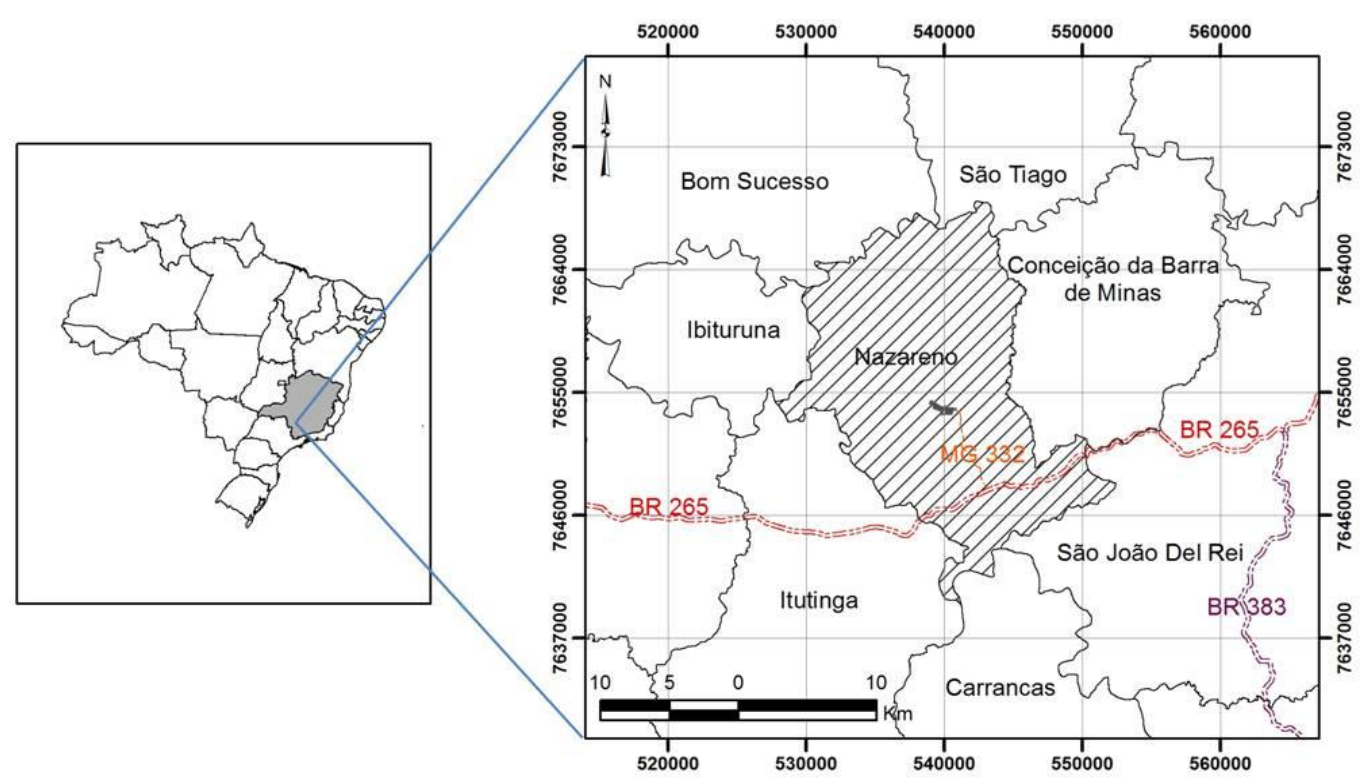

Figura 17 - Localização e acesso à área de estudo (Nazareno) e de seus municípios limítrofes. 


\subsection{Geologia}

A presença de cristas monoclinais quartzíticas cortando uma conformação de relevo com morros e colinas em serras alongadas e com deformações tectônicas caracterizam o Planalto do Alto Rio Grande e Campo das Vertentes, ao sul de Minas Gerais. Esses planaltos são constituídos por metassedimentos supracrustais proterozóicos, os quais estão presentes no Cráton do São Francisco (MARQUES NETO, 2012).

O Cráton do São Francisco se caracteriza por apresentar territórios granito-gnáissicos arqueanos e paleoproterozóicos, sucessões do tipo Greenstone Belt arquenas, como o Rio das Velhas e o de Barbacena, presença de rochas metassedimentares paleoproterozóicas, como as do Supergrupo Minas, e coberturas sedimentares plataformais neoproterozóicas (Grupo Bambuí) (TOLEDO, 2002; TEIXEIRA; ÁVILA; NUNES, 2008). A porção mais ao sul do Cráton do São Francisco é uma composição de unidades Arqueanas e Proterozóicas de distintas idades e origens, as quais, devido às atividades magmáticas, tectônicas e erosivas, expõem-se de maneira conjunta no terreno; ainda, devido aos diversos eventos de metamorfismo e deformação, estes se sobrepõem às características das rochas que os hospedam e das variadas intrusões presentes na região (ÀVILA et al., 2006; TEIXEIRA; ÁVILA; NUNES, 2008). A Figura 18 apresenta um mapa simplificado da localização do Cráton do São Francisco na América do Sul e sua geotectônica. 


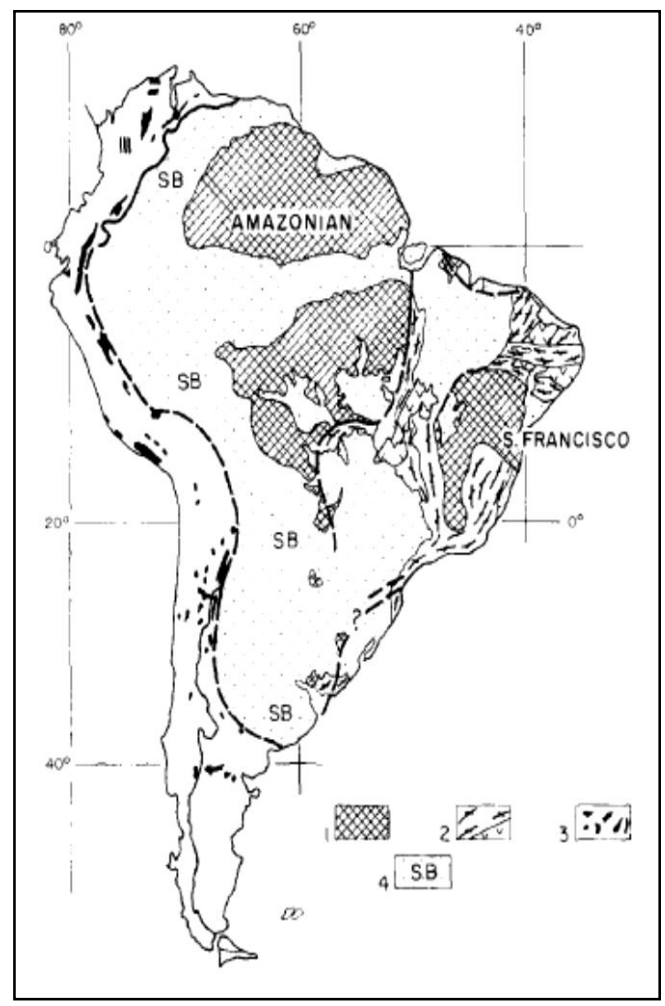

Figura 18 - Mapa geotectônico simplificado da América do Sul (Adaptada de TEIXEIRA; FIGUEIREDO, 1991). Legenda do Mapa: 1 = Crátons do Arqueano ao início do Proterozóico e fragmentos correlacionados; $2=$ Faixas móveis do final do Proterozóico com maciços de interiores; 3 = Cadeia Andina, incluindo maciços principais remobilizados do Precambriano; 4 = Sub-Andina (SB) e bacias intracratônicas do Fanerozóico.

Àvila et al. (2006) apresentam em resumo a composição desta porção do Cráton do São Francisco:

- Crosta de idade Arqueana contendo granulitos e gnaisses parcialmente migmatizados, dos Complexos Campo Belo, Bonfim, Passa Tempo e Belo Horizonte, e Greenstone Belts restantes, os quais posteriormente receberam intrusões de plutons félsicos Arqueanos, como o Supergrupo Rio das Velhas na região do Quadrilátero Ferrífero;

- Região Paleoproterozóica no limite sul do Cráton do São Francisco, a qual é composta pelos Greensonte Belts Nazareno e Rio das Mortes e por intrusões plutônicas máficas e félsicas;

- Sequências supracustais de distintas idades do Proterozóico, como o Supergrupo Minas e as Megassequências São João del Rei, Carandaí e Andrelândia.

Algumas das atividades de metamorfismo na área foram a colocação e formação de corpos graníticos e granodioríticos cortando os gnaisses do Grupo Mantiqueira, interpretadas 
por Quéméneur e Vidal (1989 apud TOLEDO, 2002) como uma acresção crustal associada ao término da evolução do Greenstone Belt Barbacena, e a intrusão de granitóides e corpos máficos durante o Paleoproterozóico, abordada por vários autores e observada em boa parte da região (TOLEDO, 2002). A Tabela 5 apresenta as características dos eventos metamórficos presentes na região.

Tabela 5 - Principais características de três eventos de deformações metamórficas reconhecidos na região de São João Del Rei - Nazareno. (Adaptado de TEIXEIRA; ÁVILA; NUNES, 2008).

Evento Metamórfico Metamorfismo Mineralogia $\quad$ Rochas Afetadas

\begin{tabular}{|c|c|c|c|}
\hline $\begin{array}{c}\text { Paleoproterozóico I: } \\
\text { 2250-2170 Ma } \\
\text { (Ávila et al., 2006) }\end{array}$ & $\begin{array}{l}\text { Fácies anfibolito } \\
\text { de grau médio }\end{array}$ & $\begin{array}{c}\text { Mg-hornblenda/Fe- } \\
\text { hornblenda }+ \text { oligoclásio ou } \\
\text { andesina } \pm \text { clorita } \pm \text { epidoto } \\
\pm \text { biotita } \pm \text { titanita } \pm \text { ilmenita } \\
\text { (Cherman, 1999; Toledo, } \\
\text { 2002) }\end{array}$ & $\begin{array}{c}\text { Anfibolitos, } \\
\text { metakomatiitos, } \\
\text { xistos, filitos, } \\
\text { gonditos e } \\
\text { quartzitos } \\
\text { (Greenstone Belts } \\
\text { Nazareno e Rio } \\
\text { das Mortes) } \\
\end{array}$ \\
\hline $\begin{array}{c}\text { Paleoproterozóico II: } \\
\mathbf{2 1 3 1} \text { - 2100 Ma (Ávila } \\
\text { et al., 2006) }\end{array}$ & $\begin{array}{l}\text { Fácies xisto } \\
\text { verde e anfibolito } \\
\text { de baixo grau }\end{array}$ & $\begin{array}{c}\text { Actinolita } \pm \text { albita } \pm \text { epidoto } \\
\pm \text { biotita } \pm \text { titanita (Ávila } \\
\text { 1992; Silva, 1996) }\end{array}$ & $\begin{array}{c}\text { Anfibolitos } \\
\text { (Greenstone Belts } \\
\text { Nazareno e Rio } \\
\text { das Mortes); } \\
\text { dunitos, } \\
\text { piroxinitos - } \\
\text { gabros; e plutons } \\
\text { Paleoproterozóicos }\end{array}$ \\
\hline $\begin{array}{c}\text { Neoproterozóico: } \\
\text { 604 e 567 Ma } \\
\text { (Söllner e Trouw, } \\
\text { 1997; Trouw e } \\
\text { Pankhust, 1993) }\end{array}$ & $\begin{array}{l}\text { Fácies xisto } \\
\text { verde a anfibolito } \\
\text { de baixo grau }\end{array}$ & $\begin{array}{c}\text { Cianita } \pm \text { biotita } \pm \text { clorita } \pm \\
\text { granada } \pm \text { cloritóide } \pm \\
\text { quartzo } \pm \text { estaurolita (Ribeiro } \\
\text { et al., } 1995)\end{array}$ & $\begin{array}{l}\text { Quartzitos, xistos } \\
\text { e filitos das } \\
\text { megassequências } \\
\text { de São João e } \\
\text { Carandaí. } \\
\text { Desenvolvimento } \\
\text { da falha NE-SW e } \\
\text { das zonas de } \\
\text { cisalhamento }\end{array}$ \\
\hline
\end{tabular}

Os litotipos encontrados nessa parte do Cráton do São Francisco, entre os municípios de Lavras e Conselheiro Lafaiete, são compostos por rochas de características metamáficas e ultramáficas com textura spinifex, xistos e anfibolitos ortoderivados, metandesitos máficos, metadacitos-metariolitos e rochas metassedimentares associadas, tais como biotita muscovita xistos, filitos, gonditos, turmalinitos e formação ferrífera bandada, e se apresentam em 
conjunto com gnaisses, migmatitos e granitos, mostrando-se de elevada complexidade em sua evolução geológica (PEREIRA; ÁVILA, 1996; TOLEDO, 2002); devido a esta variabilidade, alguns autores como Erichsen (1929), Barbosa (1954), Pires et al. (1990 apud VASQUES, 2007) e Pereira e Ávila (1996) as agruparam e as separaram na história na tentativa de encontrar uma nomenclatura comum, sendo que esta sequência foi denominada por Pires (1978 apud PEREIRA;ÁVILA, 1996) de Greenstone Belt Barbacena.

O Greenstone Belt Barbacena é formado por rochas de sucessões vulcanosedimentares e adjacentes (rochas ultramáficas e máficas metamorfizadas e rochas félsicas subvulcânicas com metassedimentares associadas), e é limitado pelos terrenos granitognáissicos tanto a norte como a sul, sendo estes apresentados como faixas descontínuas, de larguras e extensões diversas, com estruturação segundo direção NE-SW, seguindo o padrão regional (TEIXEIRA; FIGUEIREDO, 1991).

As duas Faixas que compõem o Greenstone Belt Barbacena são separadas pela Zona de Cisalhamento do Lenheiro (ZCL), sendo elas: Faixa Nazareno, composta predominantemente por rochas metaultramáficas com raras intercalações de níveis pelíticos e quartzíticos, derrames e sills máficos (rochas anfibolíticas), e Faixa Rio das Mortes, composta principalmente por rochas metamáficas com associações de rochas metassedimentares (de forma mais espessa) e metaultramáficas (de forma mais subordinada) (NUNES, 2007).

De acordo com várias pesquisas pontuadas por Rodrigues (2000), os tipos de rochas reconhecidos entre Lavras e Nazareno, nas faixas de Greenstone, são os xistos máficos, os anfibolitos, epidozitos e hornblenditos associados, os metagabros, os metadioritos, xistos ultramáficos, serpentinitos, tremolita-clorita serpentinitos e esteatitos. A Tabela 6 apresenta as características geoquímicas das rochas encontradas nesta região. 
Tabela 6 - Composição geoquímica das unidades geológicas magmática-metamórficas de ocorrência da região de Lavras, MG. Quéméneur (1995 apud LACERDA et al., 2009).

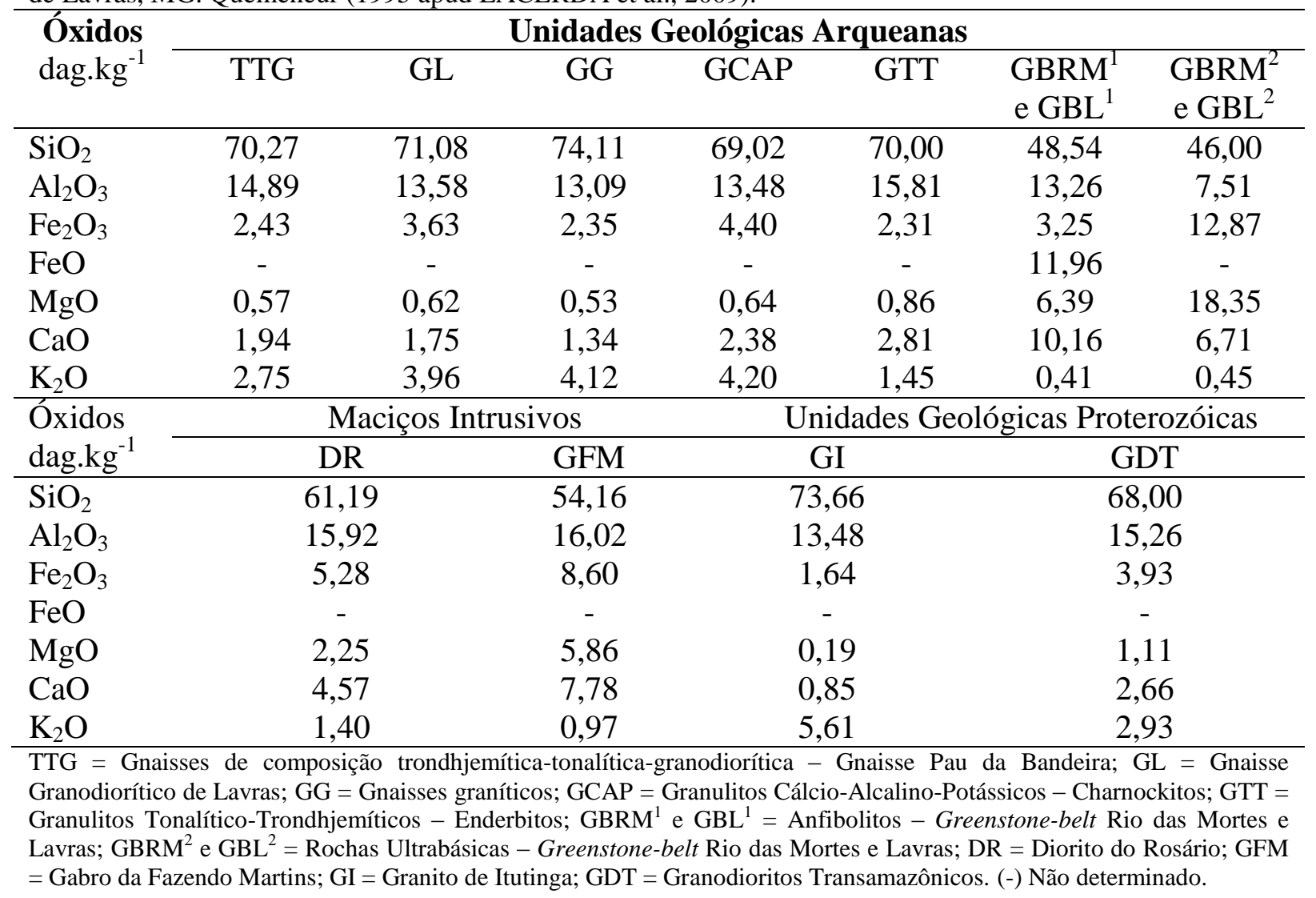

Esta região também apresenta intercalações de granitos, tonalitos, granodiroritos e trondhjemitos com graus de gnaissificação diversos e migmatização (ÁVILA, 1992 apud RODRIGUES, 2000). Algumas formas de inclusão de gnaisses bandados polideformados e migmatitos em granitos/granodioritos foliados indicam que estas rochas são de origem Arqueana na porção sul do município de Nazareno (TOLEDO, 2002).

As rochas metavulcânicas (ultramáficas) encontram-se a noroeste de Itutinga e a nordeste e sul de Nazareno. Quando afloram são como cristas de xistos ou blocos maciços semi-enterrados nas encostas, com granulação muito fina e suas cores variando de verde a cinza, sendo observados padrões de foliação tectônica $S_{n}$ (clivagens, xistosidade e bandamentos gnáissicos); apresentam-se, ainda, com grande diversidade nas texturas e mineralogia, as quais são associadas à heterogeneidade das deformações ocorridas na área (TOLEDO, 2002). Nas zonas de cisalhamento anastomosadas, por exemplo, existem faixas que contêm clorita ou talco-xistos, sendo estes últimos predominantes nos arredores daquela que limita a Faixa Nazareno e a Faixa Rio das Mortes (TOLEDO, 2002). Em relação às partes não aflorantes, observam-se essas rochas alteradas com caráter sedoso típico de talco e veios de quarzto sigmoidais; o solo gerado a partir de seu intemperismo possui coloração 
avermelhada escura, podendo ser utilizado como limitante dos contatos entre as ultramáficas e outras unidades litológicas vizinhas (TOLEDO, 2002). A Figura 19 apresenta uma forma de ocorrência de xistos ultramáficos semelhante à encontrada na área de estudo, e a Figura 20, exibe a geologia deste local.

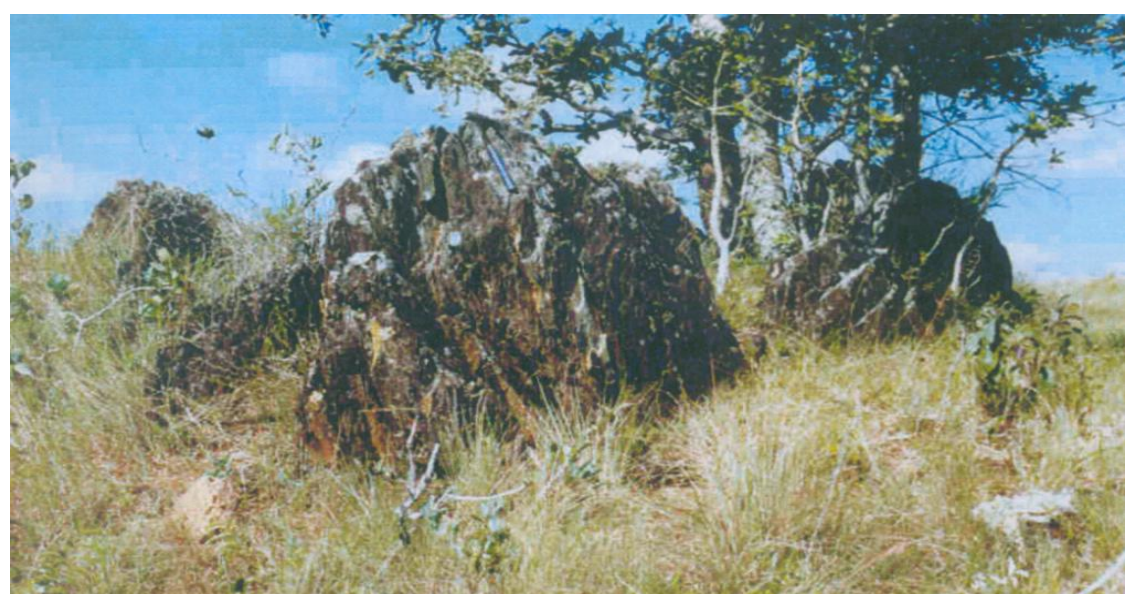

Figura 19 - Forma de ocorrência de xistos ultramáficos semelhante à encontrada na área de estudo (TOLEDO, 2002). 


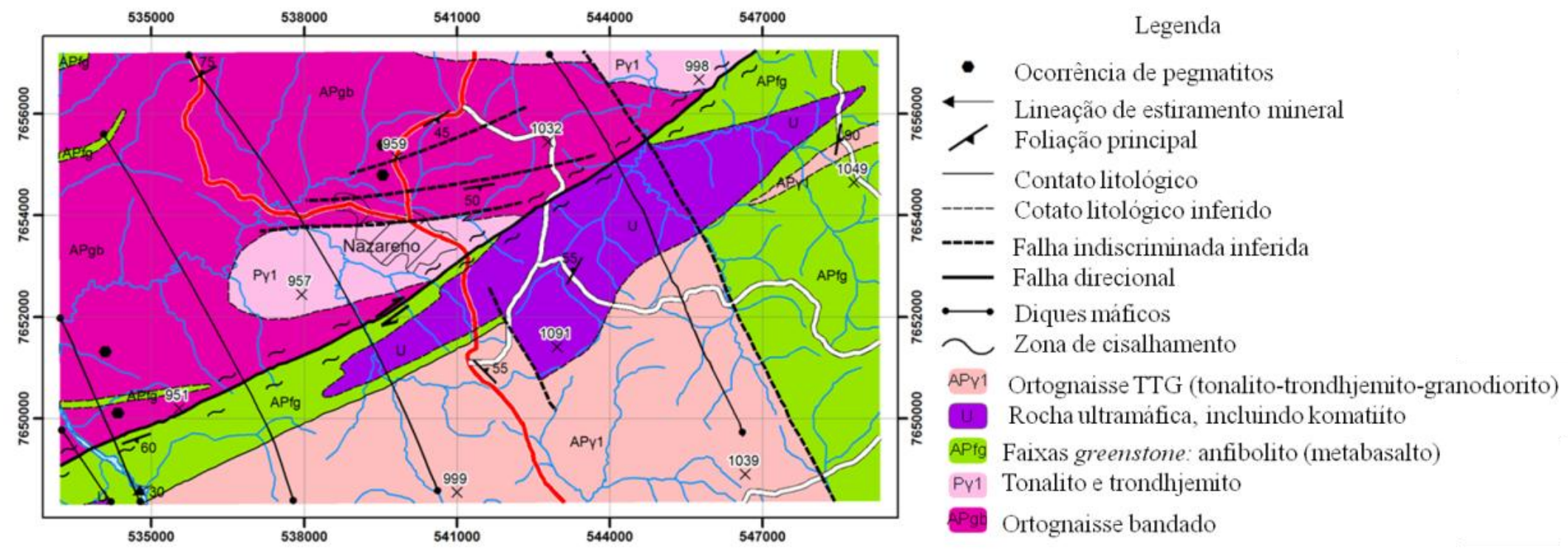

Convenção Cartográfica

$\times$ Ponto cotado

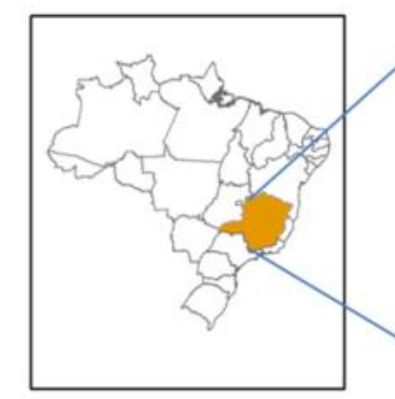

SF .23-X-C-I - Lavras/MG

$\sim$ Drenagens

$5]$ Área urbana

- Estrada náo pavimentada

- Estrada pavimentada

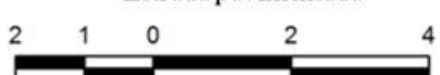
$4 \mathrm{~km}$

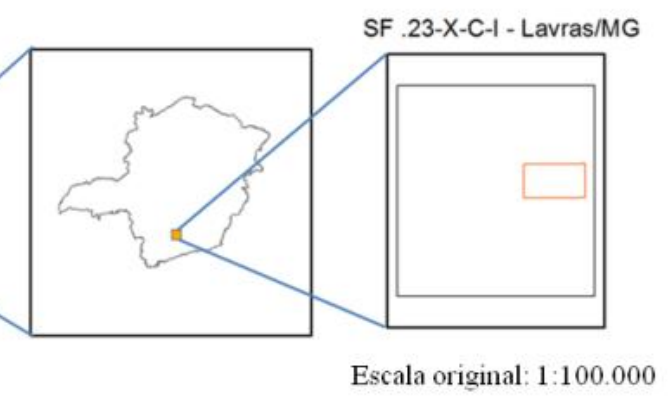

Figura 20 - Contexto geológico próximo à área urbana de Nazareno/MG. (Modificada de SAMPAIO et al., 2014). 


\subsection{Pedologia}

Dentre os tipos de solo encontrados em Nazareno, podem-se destacar quatro classes principais: Latossolos, Cambissolos, Gleissolos e Neossolos (HORTA, 2006), sendo as duas primeiras mais expressivas para a presente pesquisa e, portanto, detalhadas nos Tópicos 4.3.1 e 4.3.2, os quais tiveram embasamento em Silva (1990), Nogami e Villibor (1995), Ker (1997), Ferreira (2005), Embrapa (2006b), Horta (2006); Menezes et al. (2009), Ferreira et al. (2011) e Embrapa (2013).

\subsubsection{LATOSSOLOS}

Os Latossolos são um agrupamento de solos que apresentam o horizonte B latossólico e como atributo marcante o elevado grau de evolução e lixiviação que as regiões de clima tropical proporcionam, e que os tornam, em geral, muito profundos, capazes de alcançar mais de 10 metros de espessura. Identificados pela coloração vermelha, preponderantemente, ou amarela ou marrom (bruna), e por sua homogeneidade, exibem intensa imtemperização dos minerais primários com presença de argilominerais resistentes e/ou óxidos e hidróxidos de ferro e alumínio. O horizonte B latossólico (ou Bw) pode ser observado segundo algumas características específicas, como espessura mínima de $50 \mathrm{~cm}$, elevada estabilidade de agregados, pequena diferença entre os subhorizontes e relação silte/argila menor que 0,7. Podem apresentar, ainda, elevada porosidade aparente e permeabilidade, com presença de agregados desenvolvidos como torrões característicos (SILVA, 1990; NOGAMI e VILLIBOR, 1995; KER, 1997, EMBRAPA, 2013).

No Brasil, os latossolos já foram divididos em Latossolos Ferríferos, Latossolos Roxos, Latossolos Vermelho-Escuros, Latossolos Vermelho-Amarelos, Latossolos Amarelos, Latossolos Brunos, Latossolos Vermelho-Amarelos variação Una. Na região de Nazareno, são observados os Latossolos Vermelhos predominantemente, com ocorrência tanto dos Latossolos Vermelho como dos Vermelho-Amarelos (KER, 1997; EMBRAPA, 2006b). Atualmente, o Sistema Brasileiro de Classificação dos Solos separou os latossolos em quatro níveis categóricos: Latossolos Brunos, Latossolos Amarelos, Latossolos Vermelhos e Latossolos Vermelho-amarelos (EMBRAPA, 2013). 
Em geral estes solos se encontram em biomas de cerrado, são muito utilizados nas atividades agropecuárias, como culturas e pastagens nativas, e, apesar da aparência resistente, ao se instalar o processo erosivo, mostram-se muito susceptíveis ao voçorocamento, conforme o decréscimo da espessura dos horizontes A e B ao longo das encostas até encontrarem os talvegues (KER, 1997; FERREIRA, 2005; EMBRAPA, 2006b; HORTA, 2006; FERREIRA et al.; 2011).

Os Latossolos Vermelhos podem advir da alteração de arenitos, calcários, gnaisses e materiais retrabalhados e pré-intemperizados, o que os constitui como uma classe de considerável heterogeneidade. Os da região de interesse, em geral, são provenientes do intemperismo de gnaisses e de rochas migmatíticas; possuem espessura de até $2 \mathrm{~m}$ de solum (horizonte $\mathrm{A}+\mathrm{B}$ ), elevados teores de $\mathrm{Fe}_{2} \mathrm{O}_{3}$ e $\mathrm{Al}_{2} \mathrm{O}_{3}$ e baixos teores de $\mathrm{SiO}_{2}$ (caráter ferralítico), textura argilosa ou muito argilosa, porém, com teores de areia fina que favorecem a ocorrência de encrostamentos, e pouca coerência entre seus agregados, que podem ser carreados pelo escoamento da água. Além disso, são distróficos, possuem acidez média, baixa soma de bases e médio teor de carbono orgânico total; são muito intemperizados e porosos, o que lhes confere maior permeabilidade em relação ao Cambissolo. Em Nazareno, são encontrados nas áreas urbanas e no povoado do Palmital, entre altitudes de 925 e $990 \mathrm{~m}$, aproximadamente (SILVA, 1990; FERREIRA, 2005; EMBRAPA, 2006b; HORTA, 2006). A Figura 21 representa um perfil de Latossolo Vermelho distroférrico (LVdf), encontrado por Horta (2006) na parte norte do município de Nazareno.

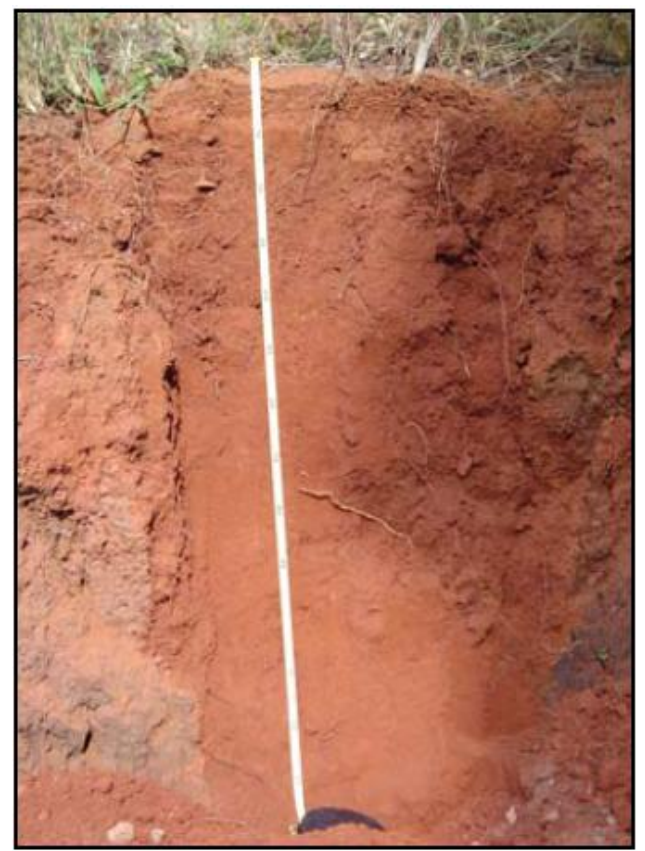

Figura 21 - Perfil de Latossolo Vermelho Distroférrico (LVdf) encontrado na área de estudo. (HORTA, 2006). 
A Tabela 7 exibe algumas características físico-químicas encontradas por Ferreira (2005) em amostras de Latossolo Vermelho coletadas nas proximidades da área urbana de Nazareno.

Tabela 7 - Características físico-químicas de Latossolo Vermelho distrófico da voçoroca do Córrego do Cravo (Nazareno/MG). Adaptado de Ferreira (2005).

\begin{tabular}{|c|c|c|c|c|}
\hline $\begin{array}{l}\text { Latossolo Vermelho } \\
\text { Distrófico (LV) }\end{array}$ & \multicolumn{2}{|c|}{ Amostragem Estrada Palmital } & \multicolumn{2}{|c|}{$\begin{array}{c}\text { Amostragem Córrego do } \\
\text { Cravo }\end{array}$} \\
\hline \multirow{2}{*}{ Coordenadas UTM (m) } & \multicolumn{2}{|c|}{541706} & \multicolumn{2}{|c|}{541086} \\
\hline & \multicolumn{2}{|c|}{7653327} & \multicolumn{2}{|c|}{7653317} \\
\hline \multirow[t]{2}{*}{ Altitude (m) } & \multicolumn{2}{|c|}{924} & \multicolumn{2}{|c|}{962} \\
\hline & Horizonte A & Horizonte $B$ & Horizonte $A$ & Horizonte $B$ \\
\hline pH & 4,8 & 4,8 & 5,0 & 5,4 \\
\hline $\begin{array}{c}\text { Carbono Orgânico Total } \\
\left({\left.\mathrm{g} . \mathrm{kg}^{-1}\right)}^{-1}\right.\end{array}$ & 14,5 & 7,5 & 12,2 & 7,5 \\
\hline \multirow{2}{*}{ Agregados } & $<0,25 \mathrm{~mm}: 5,4 \%$ & $\begin{array}{c}<0,25 \mathrm{~mm}: \\
5,2 \%\end{array}$ & $\begin{array}{c}<0,25 \mathrm{~mm}: \\
3,9 \%\end{array}$ & $\begin{array}{c}<0,25 \mathrm{~mm}: \\
1,6 \%\end{array}$ \\
\hline & $<0,5 \mathrm{~mm}: 7,2 \%$ & $\begin{array}{l}<0,5 \mathrm{~mm}: \\
7,9 \%\end{array}$ & $\begin{array}{c}<0,5 \mathrm{~mm}: \\
4,9 \%\end{array}$ & $\begin{array}{c}<0,5 \mathrm{~mm}: \\
5,0 \%\end{array}$ \\
\hline $\begin{array}{c}\text { Diâmetro Médio Geométrico } \\
(\mathrm{mm})\end{array}$ & 3,09 & 2,03 & 3,87 & 4,27 \\
\hline Silte $\left(\mathrm{g.kg}^{-1}\right)$ & 180 & 150 & 200 & 180 \\
\hline $\operatorname{Argila~}\left(\mathrm{g} . \mathrm{kg}^{-1}\right)$ & 700 & 720 & 550 & 610 \\
\hline \multirow{2}{*}{ Areia $\left(g . \mathrm{kg}^{-1}\right)$} & Fina: 60 & Fina: 70 & Fina: 90 & Fina: 100 \\
\hline & Grossa: 60 & Grossa: 60 & Grossa: 160 & Grossa: 110 \\
\hline Silte+areia fina $\left(\mathrm{g} \cdot \mathrm{kg}^{-1}\right)$ & 240 & 220 & 290 & 280 \\
\hline $\begin{array}{c}\text { Relação silte/argila } \\
\left(\mathrm{g} \cdot \mathrm{kg}^{-1}\right)\end{array}$ & 0,25 & 0,21 & 0,36 & 0,29 \\
\hline
\end{tabular}

Os Latossolos Vermelho-Amarelos são observados na maior parte do município, sendo mais presentes onde o relevo é suavemente ondulado a ondulado. Pode ser encontrado entre as altitudes de 870 e $1045 \mathrm{~m}$, estando associados a declividades de 5 a 17\%. Em geral são provenientes da alteração de gnaisses graníticos, podendo ter influência de micaxistos. Também são muito intemperizados, possuem características distróficas, com textura argilosa, acidez média, soma de bases baixa, teor de carbono orgânico total médio no horizonte A e são muito porosos, porém, com elevados teores de areia fina e menor permeabilidade em relação ao Latossolo Vermelho-Escuro. Apresentam baixos teores de $\mathrm{SiO}_{2}$ e maiores teores de $\mathrm{Al}_{2} \mathrm{O}_{3}$, baixa fertilidade e grau moderado de susceptibilidade à erosão, sendo utilizados para 
pastagens, preferivelmente. Seu horizonte $\mathrm{Bw}$ apresenta cor menos avermelhada que o Latossolo Vermelho-Escuro (SILVA, 1990; FERREIRA, 2005; EMBRAPA, 2006b; HORTA, 2006). A Figura 22 apresenta um perfil de Latossolo Vermelho-Amarelo distrófico (LVAd) observado por Horta (2006).

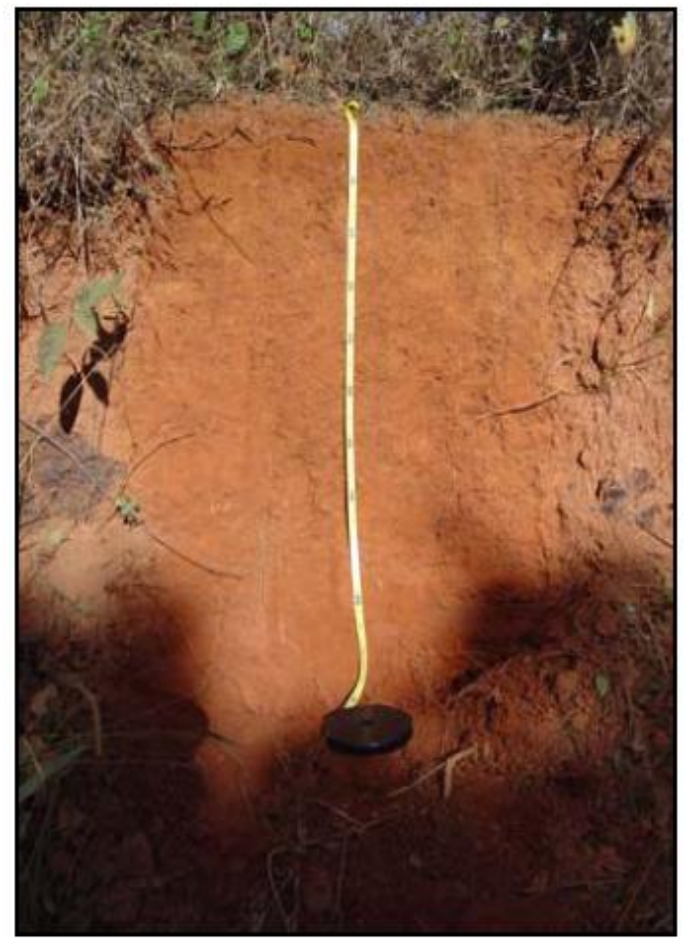

Figura 22 - Perfil de Latossolo Vermelho-Amarelo distrófico (LVAd). (HORTA, 2006).

\subsubsection{CAMBISSOLOS}

Os horizontes saprolíticos das regiões tropicais usualmente possuem características estruturais semelhantes às das rochas das quais se originaram, como a estratificação, por exemplo. Entretanto, com o desencadear do intemperismo, podem ocorrer alterações que adicionam outras estruturas, tornando-as de complexidade mais elevada em relação àquelas esperadas para a área, com certo grau de dificuldade para esta identificação (NOGAMI e VILLIBOR, 1995). Sendo assim, pelo Sistema Brasileiro de Classificação de Solos, os Cambissolos (do latim cambiare - trocar, mudar) são solos ainda em formação, isto é, com menor desenvolvimento; apresentam o horizonte B incipiente e podem exibir características variáveis para cada local, de acordo com as condições climáticas e geomorfológicas, por exemplo (EMBRAPA, 2013). 
Os Cambissolos da região do Alto Rio Grande, em geral, são solos saprolíticos que possuem origem nos micaxistos, quartzitos, xistos, biotita-xistos, filitos e metarenitos ferruginosos, ardósias da Formação Sete Lagoas e xistos argilosos, migmatitos e charnockitos, e apresentam coloração mais clara que os Latossolos. É comum estarem em associação com afloramentos de rochas e apresentarem cascalhos de quartzo e micaxistos na superfície do solo e ao longo do perfil, sendo que sua evolução é baixa em relação aos Latossolos e apresentam grande variabilidade de características, influenciadas pelo material que os originou (SILVA, 1990; FERREIRA, 2005; EMBRAPA, 2006b; HORTA, 2006).

A espessura do solum geralmente é inferior, com horizonte B incipiente (Bi), sendo o horizonte $\mathrm{C}$ mais profundo e pronunciado; apresenta pobreza química, textura média com elevados teores de silte e areia fina, elevada susceptibilidade ao encrostamento e ao voçorocamento, pois também é comum estarem associados com relevo ondulado e fortemente ondulado (declividades entre 11 e 40\%) (SILVA, 1990; FERREIRA, 2005; EMBRAPA, 2006b; HORTA, 2006).

Apresentam baixa permeabilidade, níveis de saturação por alumínio de médio a alto, argilas de baixa atividade e são muito erodíveis em relação aos outros tipos de solos, principalmente pela erosão hídrica, devido ao favorecimento do escoamento superficial. Apresentam acidez média, baixa soma de bases e teor de carbono orgânico de baixo a médio. Por estas características, o crescimento de vegetação é dificultado; entretanto, o aparecimento de pteridófitas pode indicar o seu restabelecimento (SILVA, 1990; NOGAMI e VILLIBOR, 1995; FERREIRA, 2005; EMBRAPA, 2006b; HORTA, 2006).

No município de Nazareno os Cambissolos se apresentam em altitudes que variam de aproximadamente 915 a 1030 m, sendo observados na área urbana, na estrada de Palmital, na região de Palmital de baixo, na Fazenda Barroso, e próximos ao Rio das Mortes (FERREIRA, 2005; HORTA, 2006). A Figura 23 apresenta um exemplo de Cambissolo Háplico Distrófico típico (Cxbd), descrito por Horta (2006). 


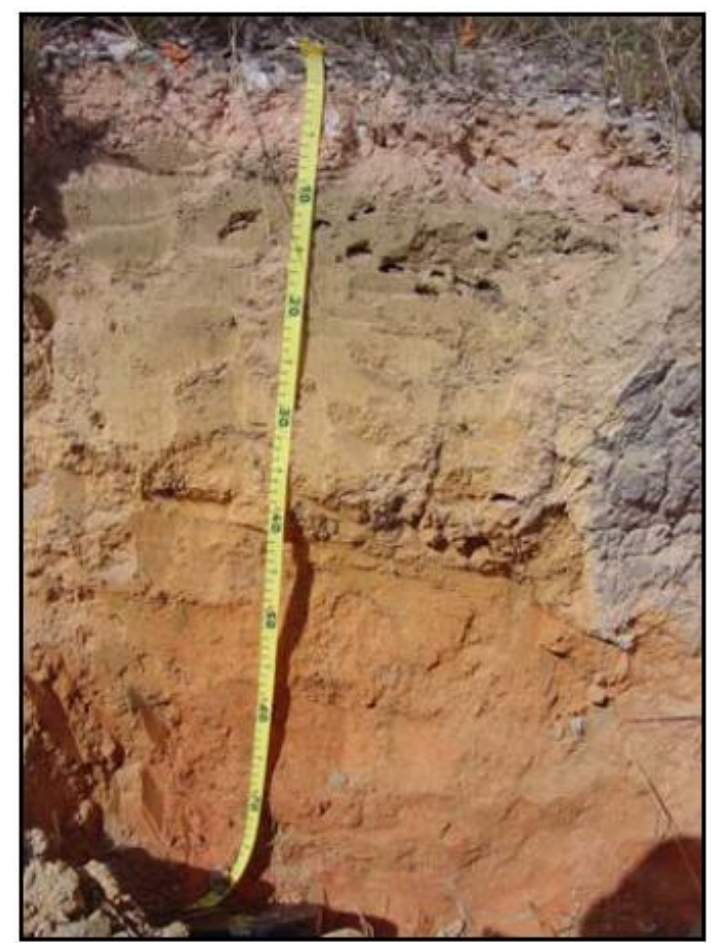

Figura 23 - Perfil de Cambissolo Háplico Distrófico (Cxbd). (HORTA, 2006).

Muitos dos problemas relacionados ao aparecimento de voçorocas na região do Alto Rio Grande são associados ao inapropriado uso do solo e às atividades de mineração (SILVA, 1990; FERREIRA, 2005; HORTA, 2006; MENEZES et al., 2009; FERREIRA et al., 2011). Algumas destas regiões, como Lavras e Nazareno, possuem características pedológicas semelhantes, e que, ao passarem pelos processos de uso e ocupação, apresentam comportamentos muito próximos em relação à erosão do solo. A Tabela 8 apresenta um resumo de algumas ocorrências para Lavras. 
Tabela 8 - Relação entre superfícies de erosão, marcos geográficos, altitudes, principais rochas de origem e solos predominantes da região de Lavras - MG. Adaptado de CURI et al. (1990 apud SILVA, 1990).

\begin{tabular}{|c|c|c|c|c|}
\hline $\begin{array}{l}\text { Superfície } \\
\text { de Erosão }\end{array}$ & $\begin{array}{c}\text { Marco } \\
\text { Geográfico }\end{array}$ & $\begin{array}{l}\text { Faixa de } \\
\text { Altitude } \\
\quad(\mathbf{m}) \\
\end{array}$ & $\begin{array}{l}\text { Rochas } \\
\text { Principais }\end{array}$ & Solos Predominantes \\
\hline $1^{\mathrm{a}}$ Gondwana & $\begin{array}{c}\text { Serra da Bocaina } \\
\text { Serra do } \\
\text { Campestre } \\
\text { Serra do Faria } \\
\end{array}$ & $\begin{array}{l}1100- \\
1300\end{array}$ & $\begin{array}{l}\text { Quartzitos e } \\
\text { Micaxistos }\end{array}$ & $\begin{array}{l}\text { Solo Litólico Álico textura } \\
\text { média, Cambissolo Álico } \\
\text { textura média }\end{array}$ \\
\hline $\begin{array}{c}2^{\mathrm{a}} \text { Pós- } \\
\text { Gondwana }\end{array}$ & $\begin{array}{c}\text { Serra do Gambá } \\
\text { Serra do Pau D } \\
\text { Oleo } \\
\text { Serrinha }\end{array}$ & 990-1090 & $\begin{array}{l}\text { Gnaisse granítico } \\
\text { leucocrático e } \\
\text { quartzitos }\end{array}$ & $\begin{array}{l}\text { Solo Litólico álico textura } \\
\text { média, Solo Litólico } \\
\text { distrófico textura média, } \\
\text { Podzólico Vermelho- } \\
\text { Amarelo Distrófico textura } \\
\text { média/argilosa }\end{array}$ \\
\hline $\begin{array}{c}3^{\mathrm{a}} \mathrm{Sul} \\
\text { americana }\end{array}$ & $\begin{array}{l}\text { Superfície geral } \\
\text { (Cidade de } \\
\text { Lavras) }\end{array}$ & $875-950$ & $\begin{array}{l}\text { Gnaisse granítico } \\
\text { leucocrático e } \\
\text { mesocrático }\end{array}$ & $\begin{array}{c}\text { Latossolo Vermelho- } \\
\text { Amarelo Epiálico } \\
\text { Endodistrófico câmbico } \\
\text { textura argilosa, Latossolo } \\
\text { Vermelho-Escuro Epiálico } \\
\text { Endodistrófico textura } \\
\text { muito argilosa }\end{array}$ \\
\hline $4^{\mathrm{a}}$ Velhas & $\begin{array}{c}\text { Superfície } \\
\text { intermediária } \\
\text { (Cidade de Ijaci) }\end{array}$ & $815-870$ & $\begin{array}{c}\text { Gnaisse granítico e } \\
\text { calcários }\end{array}$ & $\begin{array}{c}\text { Latossolo Vermelho- } \\
\text { Amarelo Distrófico } \\
\text { câmbico textura argilosa, } \\
\text { Latossolo Vermelho-Escuro } \\
\text { Álico textura muito } \\
\text { argilosa, Latossolo } \\
\text { Vermelho-Escuro Álico } \\
\text { textura argilosa }\end{array}$ \\
\hline $5^{\mathrm{a}}$ Paraguaçu & $\begin{array}{l}\text { Margens do Rio } \\
\text { Grande }\end{array}$ & $800-810$ & $\begin{array}{c}\text { Sedimentos } \\
\text { predominantemente } \\
\text { areno-siltosos }\end{array}$ & $\begin{array}{c}\text { Solo Aluvial Eutrófico } \\
\text { textura média }\end{array}$ \\
\hline
\end{tabular}




\subsection{Geomorfologia}

A região denominada "Planalto dos Campos das Vertentes", na qual se insere o município de Nazareno, contempla um agrupamento de relevos dissecados, nos quais se verifica uma variação de altitude entre 400 e 1300 metros, onde predominam as colinas e morros de vertentes convexo-côncavas, modeladas em terrenos granítico-gnáissicos. Esta região se insere na unidade geomorfológica "Planalto dos Campos das Vertentes", que é uma subdivisão do "Planalto Centro Sul de Minas", o qual pertence ao domínio morfoestrutural “Escudo Exposto” (BRASIL, 1983 apud EMBRAPA, 2006b; EMBRAPA, 2006b).

De maneira geral, é possível separar o Planalto dos Campos das Vertentes em três compartimentos, para maior detalhamento (EMBRAPA, 2006b), sendo que o município de Nazareno se encontra na microrregião Campos da Mantiqueira (EMBRAPA, 2006a):

- Microrregião Formiga e parte da microrregião Campos da Mantiqueira: esta região possui topografia em relevo mais suavizado, com dominância de modelados de dissecação homogênea com colinas convexo-côncavas que têm como limites talvegues pouco profundos, sendo esta paisagem foco para as atividades agrícolas. Feições mais aguçadas podem surgir de topos nivelados, apresentando rochas mais resistentes à erosão; ocorrem com frequência linhas de quartzo, geralmente em níveis planos, mas que podem estar presentes em depressões, denotando possíveis processos de pediplanação a que o relevo foi submetido.

- Região aproximada da microrregião Campos da Mantiqueira (parte oriental da unidade): também apresentam modelados de dissecação homogênea com grandes colinas e morros de topos convexo-côncavos, porém, linhas de cumeada e cristas de topos aguçados podem preponderar. Nesta região, as drenagens são mais profundas, configurando vales em "V" encaixados, e o relevo se apresenta fortemente ondulado e montanhoso.

- Área menor inserida no "Planalto de Andrelândia" (subdivisão dos "Planaltos do Alto Rio Grande"), região geomorfológica contida no domínio morfoestrutural "Remanescentes de Cadeias Dobradas" (BRASIL, 1983 apud 
EMBRAPA, 2006b). Esta região também pertence à microrregião Campos da Mantiqueira, especificamente nos municípios de São João Del Rei, Tiradentes, Barroso e Barbacena. O relevo apresenta dissecação homogênea como nas outras áreas; entretanto, apresenta colinas com topos convexos tabulares a encostas suavizadas com intercalações de cristas alongadas assimétricas. Apresentam, ainda, densidades de drenagem de média a baixa. Neste compartimento, é frequente a presença de voçorocas de grandes dimensões (tanto em extensão como em largura).

A Tabela 9 exibe a correlação entre as classes de declividade e os tipos de solo encontrados para a região de Lavras. Observa-se que em classes de declividades baixas existe o predomínio de Latossolos, e que, conforme o relevo vai se tornando mais ondulado a montanhoso, os Cambissolos podem predominar no perfil.

Tabela 9 - Modelo geomorfológico-pedológico da região de Lavras. (ANDRADE et al., 1998 apud LACERDA et al., 2009).

\begin{tabular}{|c|c|c|}
\hline $\begin{array}{c}\text { Classes de declividade } \\
(\%)\end{array}$ & Classes de relevo & $\begin{array}{c}\text { Classes de solos } \\
\text { (EMBRAPA, 2006) }\end{array}$ \\
\hline $0-3$ (Topo) & Plano (Topo) & Latossolos \\
\hline 0-3 (Planície aluvial) & Plano (Planície aluvial) & $\begin{array}{l}\text { Solos Hidromórficos e Neossolos } \\
\text { Flúvicos }\end{array}$ \\
\hline $3-12$ & Suave ondulado & Latossolos \\
\hline $12-24$ & Ondulado & $\begin{array}{l}\text { Solos com horizonte B textural e B } \\
\text { nítico }\end{array}$ \\
\hline $24-45$ & Forte ondulado & $\begin{array}{l}\text { Solos com horizonte B textural e B } \\
\text { nítico e Cambissolos }\end{array}$ \\
\hline$>45$ & Montanhoso & Cambissolos e Neossolos Litólicos \\
\hline
\end{tabular}

Em relação à Nazareno, em grande parte o relevo se apresenta ondulado, sem a presença de escarpas ou montanhas, sendo que as altitudes variam entre 839 e 1140 metros. Acrescenta-se que as declividades e altitudes mais elevadas e os relevos forte-ondulados são encontrados a nordeste do município; as áreas de várzea e os topos de morros podem ser observados nas áreas planas, as quais são distribuídas no restante da área (HORTA et al., 2009). A Figura 24 ilustra a conformação do relevo mais próximo à área urbana. 


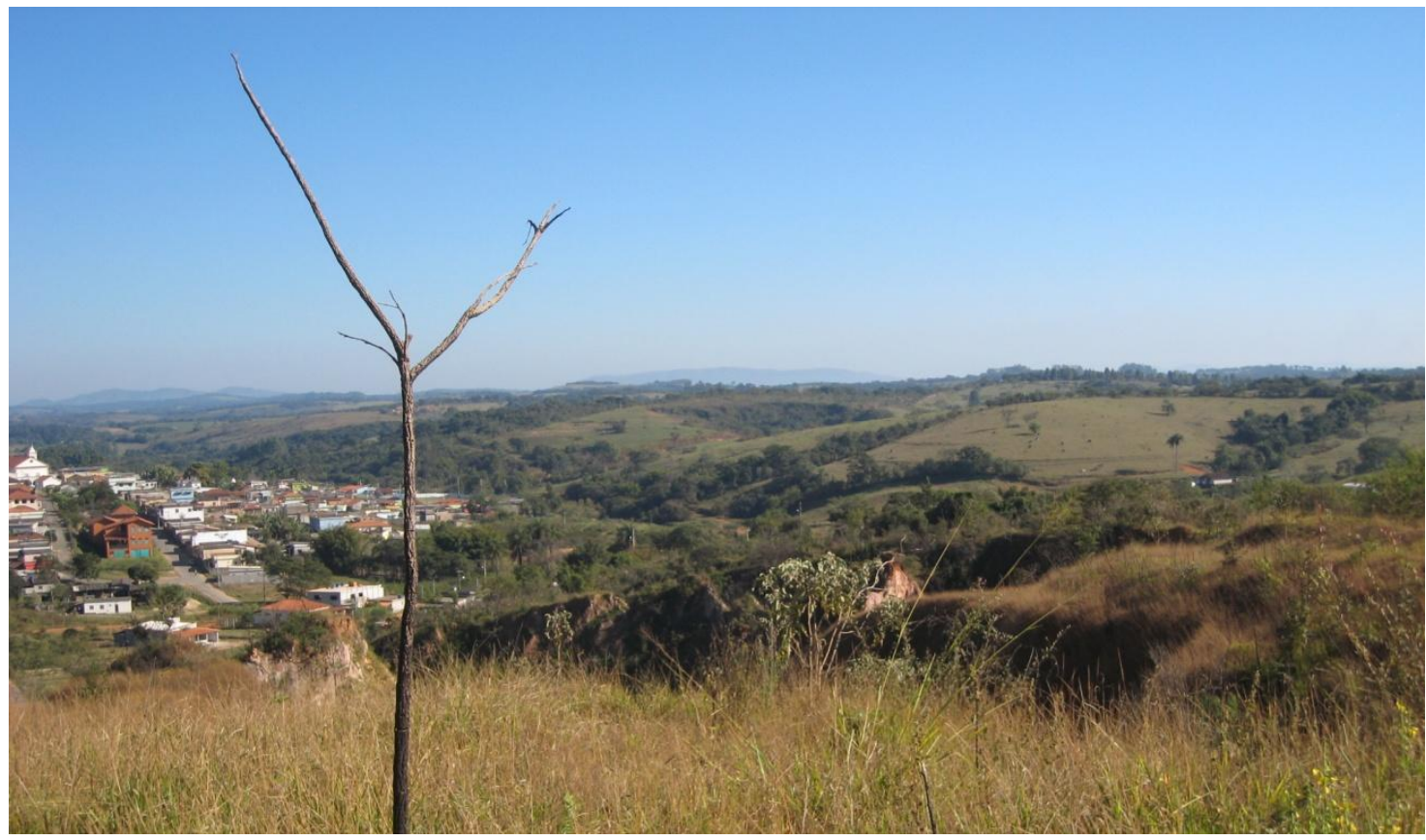

Figura 24 - Conformação do relevo próximo à área urbana de Nazareno/MG.

\subsection{Clima}

Por suas elevadas proporções, diversidade de relevo montanhoso e por receber massas de ar distintas, o estado de Minas Gerais apresenta variabilidade na origem e intensidade de suas precipitações; eventos como chuvas volumosas provocadas pelas zonas de baixa pressão atmosférica no Oceano Atlântico (zonas de convergência do atlântico sul) e chuvas convectivas de elevada intensidade e pouca duração, principalmente nas áreas mais quentes, com grande potencial erosivo, são registrados nesta porção do Brasil (MOREIRA, 1999 e 2002 e VIANELLO e ALVES, 2000 apud MELLO et al., 2007).

Mello et al. (2007) apontam que, para o estado mineiro, a erosividade das chuvas possui valores de médio a muito elevados; mesmo sendo esta característica relacionada ao clima e aos efeitos orogenéticos de cada região, verifica-se que este valor aumenta muito, chegando até a triplicar em novembro, com o aumento da quantidade de chuvas relacionadas aos meses de alta pluviosidade. As Figuras 25 e 26 apresentam os mapas de erosividade das chuvas e precipitação anual no estado de Minas Gerais, respectivamente. 


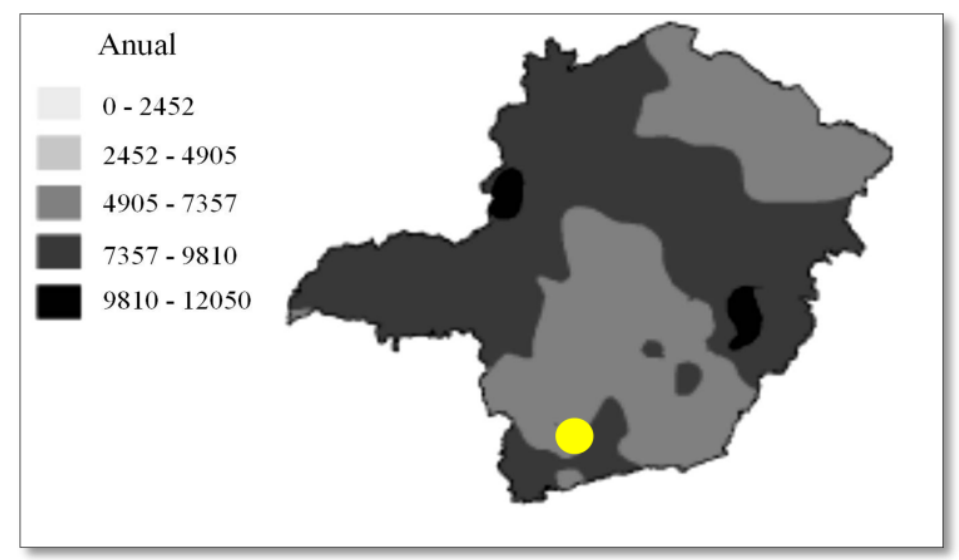

Figura 25 - Erosividade anual das chuvas no estado de Minas Gerais (MJ.mm.ha ${ }^{-1}$ ); em amarelo a localização aproximada de Nazareno (Adaptada de MELLO et al., 2007).

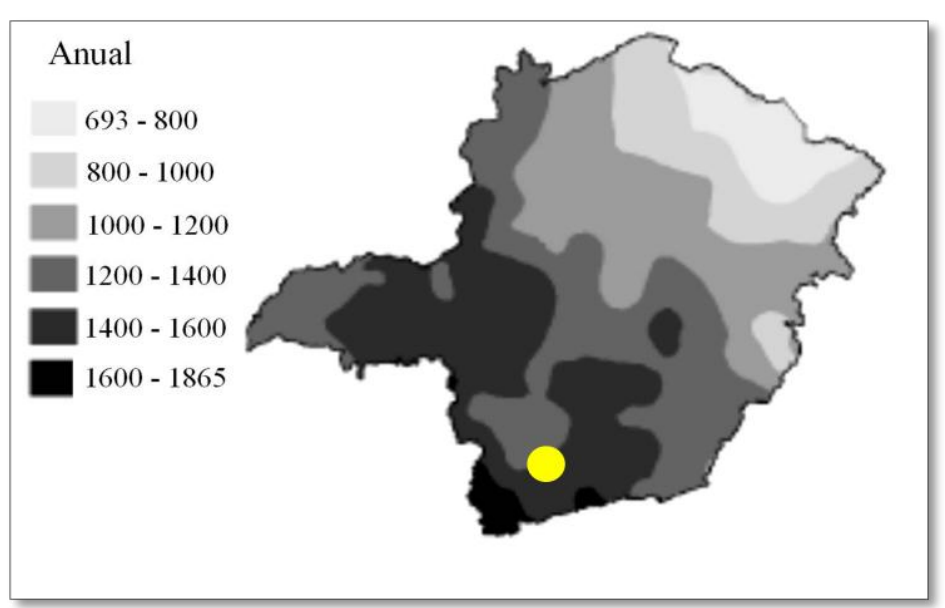

Figura 26 - Precipitação anual (mm) no estado de Minas Gerais; em amarelo a localização aproximada de Nazareno (Adaptada de MELLO et al., 2007).

Segundo EMBRAPA (2006a), em São João Del Rei, a leste de Nazareno, onde predominam altitudes próximas a $860 \mathrm{~m}$, o clima é classificado como Cwa (de acordo com a classificação de Köppen), sendo que o inverno se caracteriza por ser seco e o verão chuvoso, com temperaturas variando entre 18,7 a $22,2^{\circ} \mathrm{C}$ e precipitação total média de $1244 \mathrm{~mm}$ na época entre a primavera e o verão, e com variações de $15,5^{\circ} \mathrm{C}$ a $19,5^{\circ} \mathrm{C}$ e precipitação de 192 mm nas estações de outono/inverno.

Em Lavras, a oeste de Nazareno, pode-se observar que, em local com altitude de 925 m, o clima predominante é mesotérmico com verões brandos e suaves e estiagem nos invernos, precipitação média anual de $1529 \mathrm{~mm}$ e temperatura média mensal de $19,5^{\circ} \mathrm{C}$, sendo o mesmo classificado como Cwb de acordo com Köppen (OLIVEIRA-FILHO et al., 1994 apud DIAS; OLIVEIRA-FILHO, 1996). Conforme Dantas, Carvalho e Ferreira (2007), nas 
porções do município de Lavras com $918 \mathrm{~m}$ de altitude, o clima pode ser classificado como Cwa (classificação de Köppen). Nesse mesmo estudo, compararam-se os dados de temperatura e pluviosidade entre séries históricas de 1961 a 1990 com as de 1991 a 2004, encontrando-se variações entre tais séries históricas (DANTAS; CARVALHO; FERREIRA, 2007). A mudança entre essas classificações (Cwb e Cwa) está relacionada com as diferenças de altitudes, que, em média superiores a 900 m, caracterizam o clima em Cwb (EMBRAPA, 2006a).

Diante disso, pode-se afirmar que o município de Nazareno possui características climáticas muito semelhantes a Lavras e São João Del Rei, e, a partir da Figura 26, pode-se considerar sua precipitação total anual entre 1200 e $1400 \mathrm{~mm}$.

Os Gráficos 1, 2 e 3 apresentam dados de pluviosidade de três anos distintos da usina hidrelétrica de Itutinga (estações da Usina Hidrelétrica- UHE Itutinga - CEMIG), localizada no limite sul do município de Nazareno. Pode-se observar que os meses chuvosos estão entre setembro e março e que, de abril a agosto, quase não se verifica precipitação para esta localidade, podendo-se correlacionar a ocorrência de chuvas no verão e primavera, e a estiagem no final do outono e inverno.

É possível verificar, ainda, que os anos de 1985 e 1992 apresentam maiores quantidades totais de chuvas próximas ao início do ano $(622,5 \mathrm{~mm}$ e $619,6 \mathrm{~mm}$, respectivamente, no mês de janeiro), enquanto que em 2010 esses valores passam a se concentrar mais próximos do final do ano, com quantidade menor que nos outros anos $(407,7$ mm em novembro). Observa-se, também, que os maiores valores das máximas mensais exibem o mesmo comportamento, sendo encontrados valores de 97,9 mm para 1985, 164,0 mm para 1992, e 101,0 mm para 2010; em geral, os meses nos quais não se verifica chuva significativamente são junho (máximas de 8,8 mm em 1985 e 6,5 em 2010), julho (máximas de 8,7 mm em 1992 e 8,2 mm em 2010) e agosto (não houve chuva em todos os anos). 


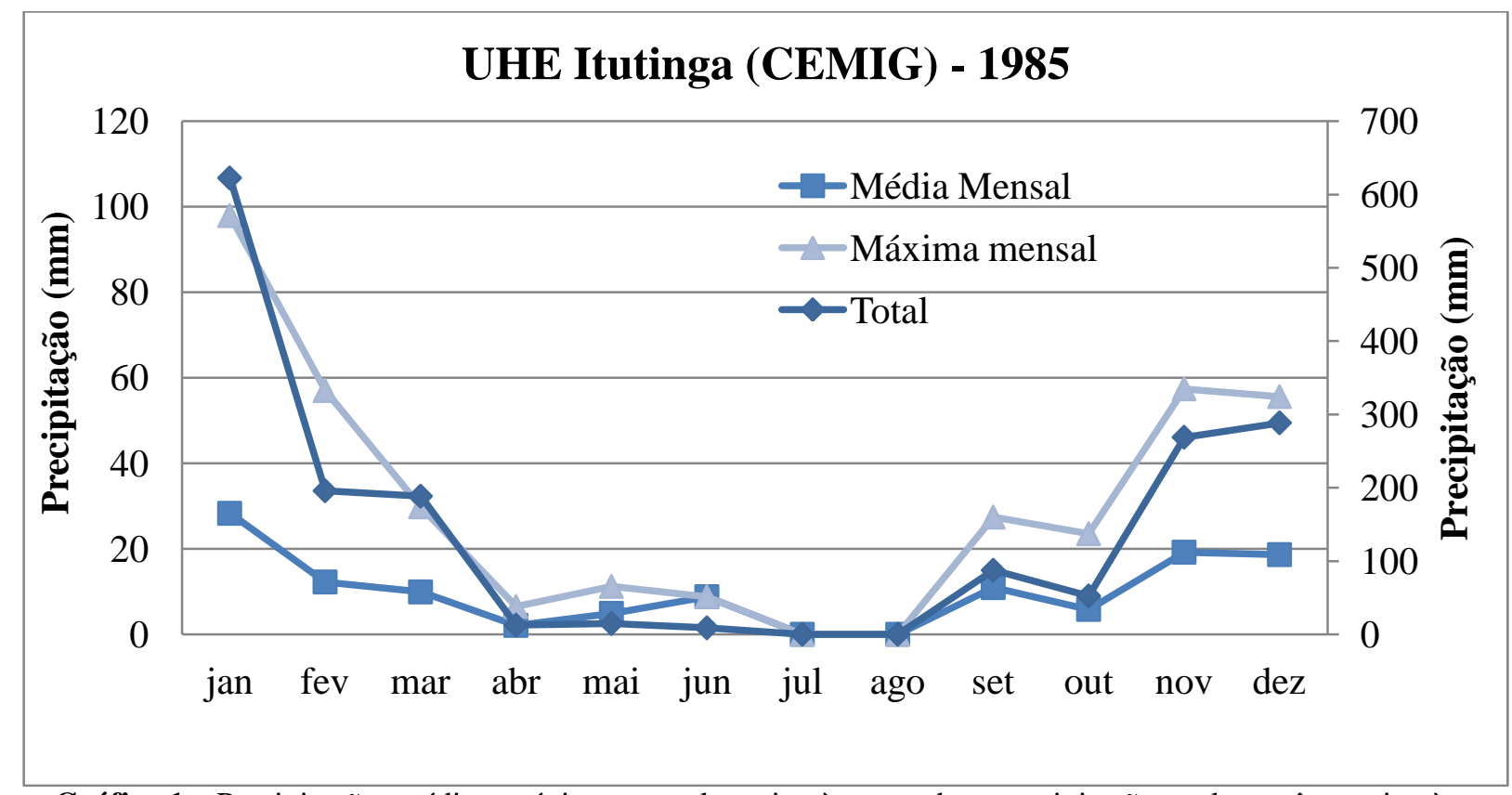

Gráfico 1 - Precipitações média e máxima mensal no eixo à esquerda, e precipitação total no mês no eixo à direita, para o ano de 1985. (UHE Itutinga - CEMIG).

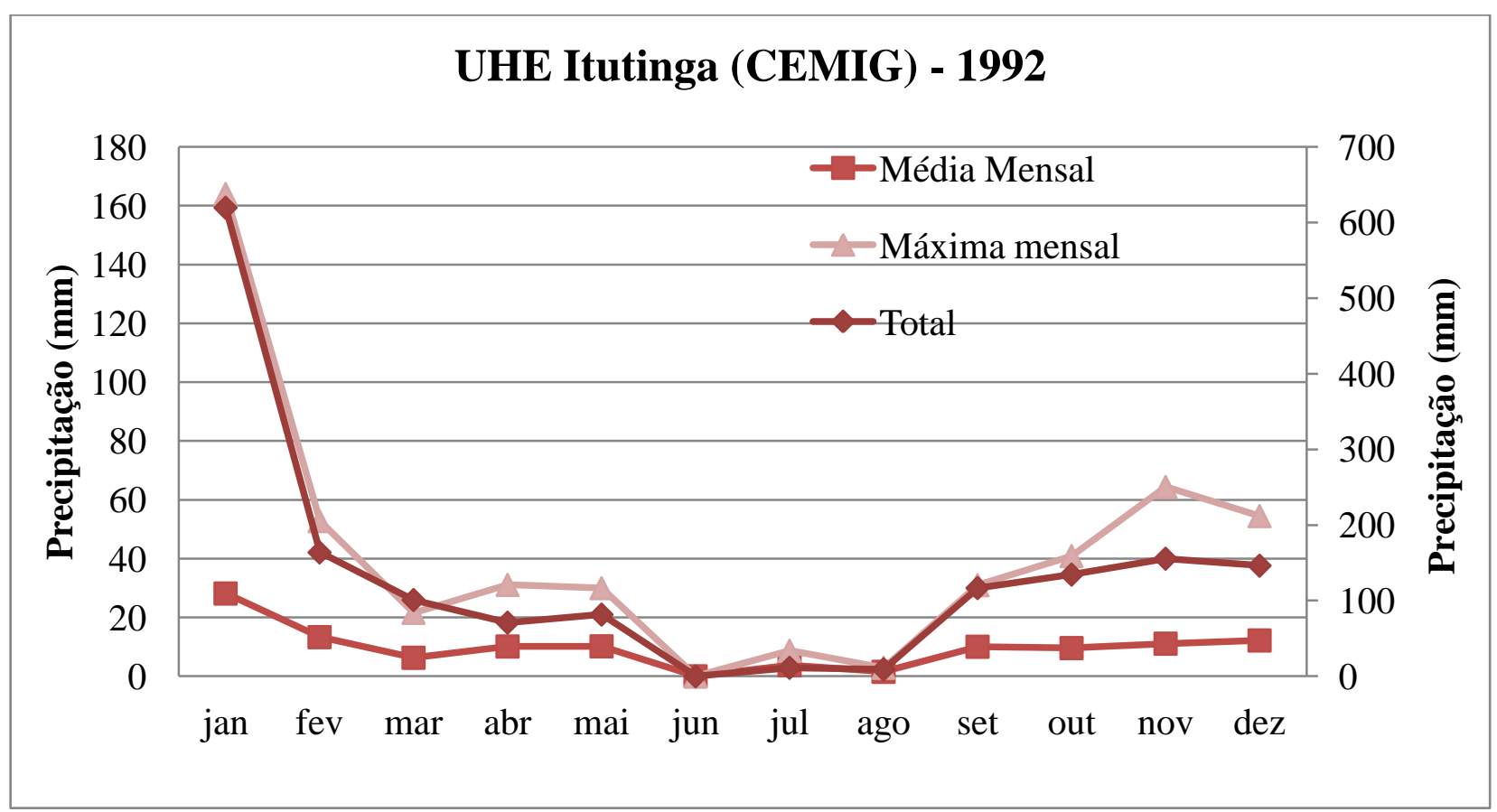

Gráfico 2 - Precipitações média e máxima mensal no eixo à esquerda, e precipitação total no mês no eixo à direita, para o ano de 1992. (UHE Itutinga - CEMIG). 


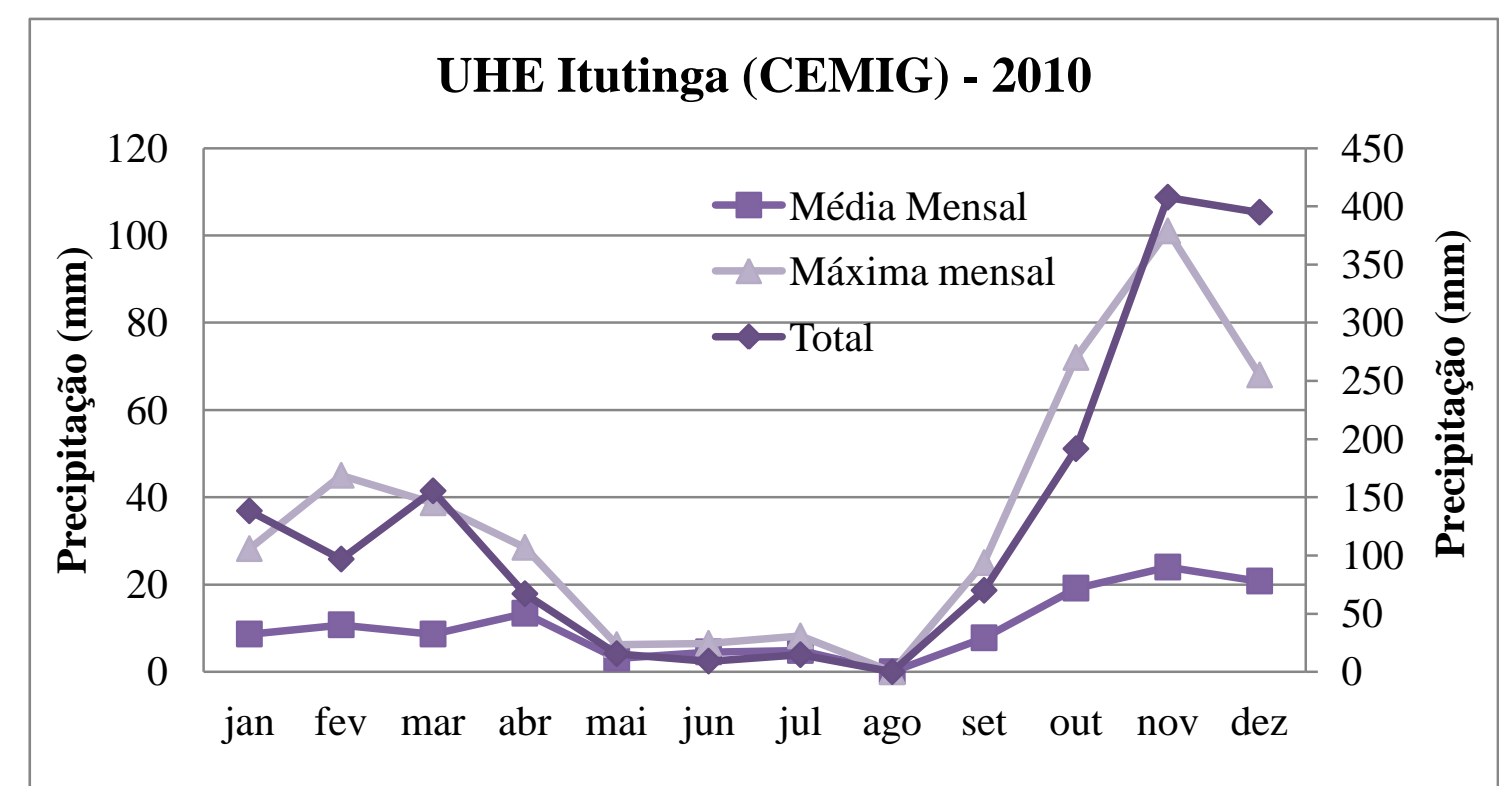

Gráfico 3 - Precipitações média e máxima mensal no eixo à esquerda, e precipitação total no mês no eixo à direita, para o ano de 2010. (UHE Itutinga - CEMIG).

Os anos de 2011, 2012 e 2013, mesmo apresentando ausência de dados, mostram que o comportamento das chuvas nos últimos três anos (Gráficos 4, 5 e 6) não diferiu do que ocorreu nos anos anteriormente citados: os meses com as máximas observadas no ano geralmente vão de novembro a janeiro $(92,0 \mathrm{~mm}$ para 2011, 70,0 mm para 2012 e 62,0 mm para 2013), verificando-se que os maiores valores totais de precipitação são de 504,0 mm para janeiro de 2011, 294,0 mm para 2012 e 462,0 mm para 2013. 


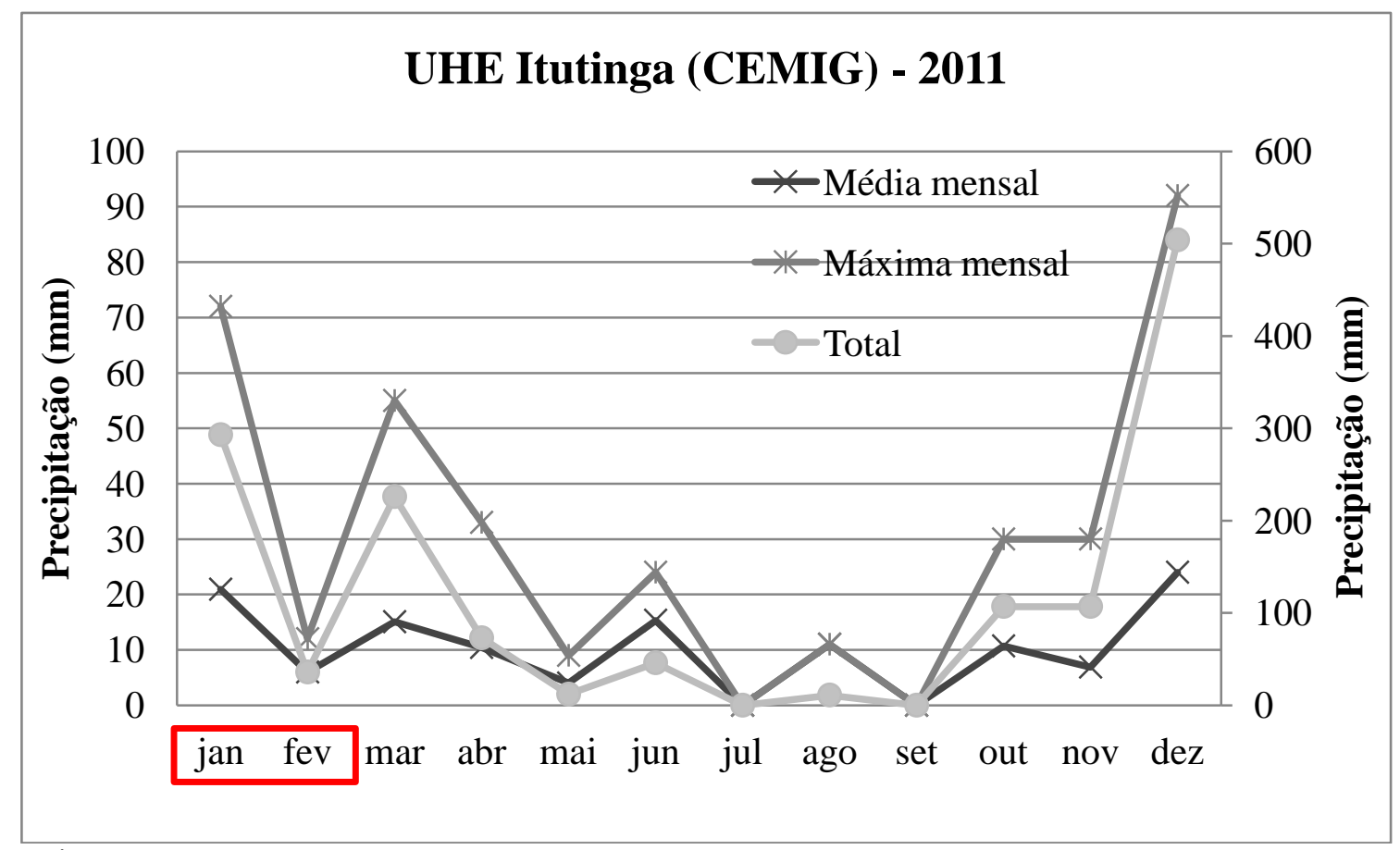

Gráfico 4 - Precipitações média e máxima mensal no eixo à esquerda, e precipitação total no mês no eixo à direita, para o ano de 2011. A marcação em vermelho indica os meses nos quais faltam dados (UHE Itutinga CEMIG).

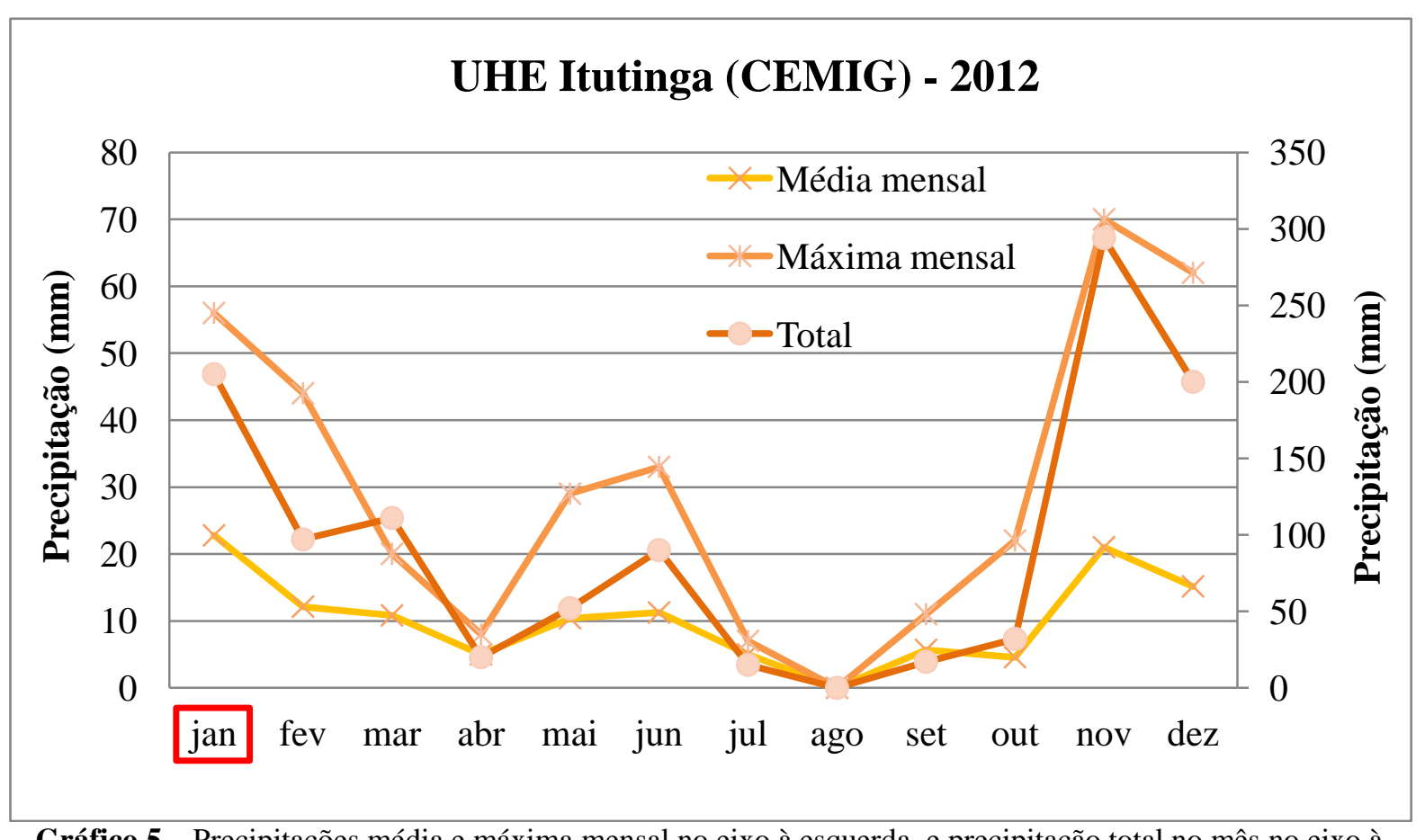

Gráfico 5 - Precipitações média e máxima mensal no eixo à esquerda, e precipitação total no mês no eixo à direita, para o ano de 2012. A marcação em vermelho indica os meses nos quais faltam dados (UHE Itutinga CEMIG). 


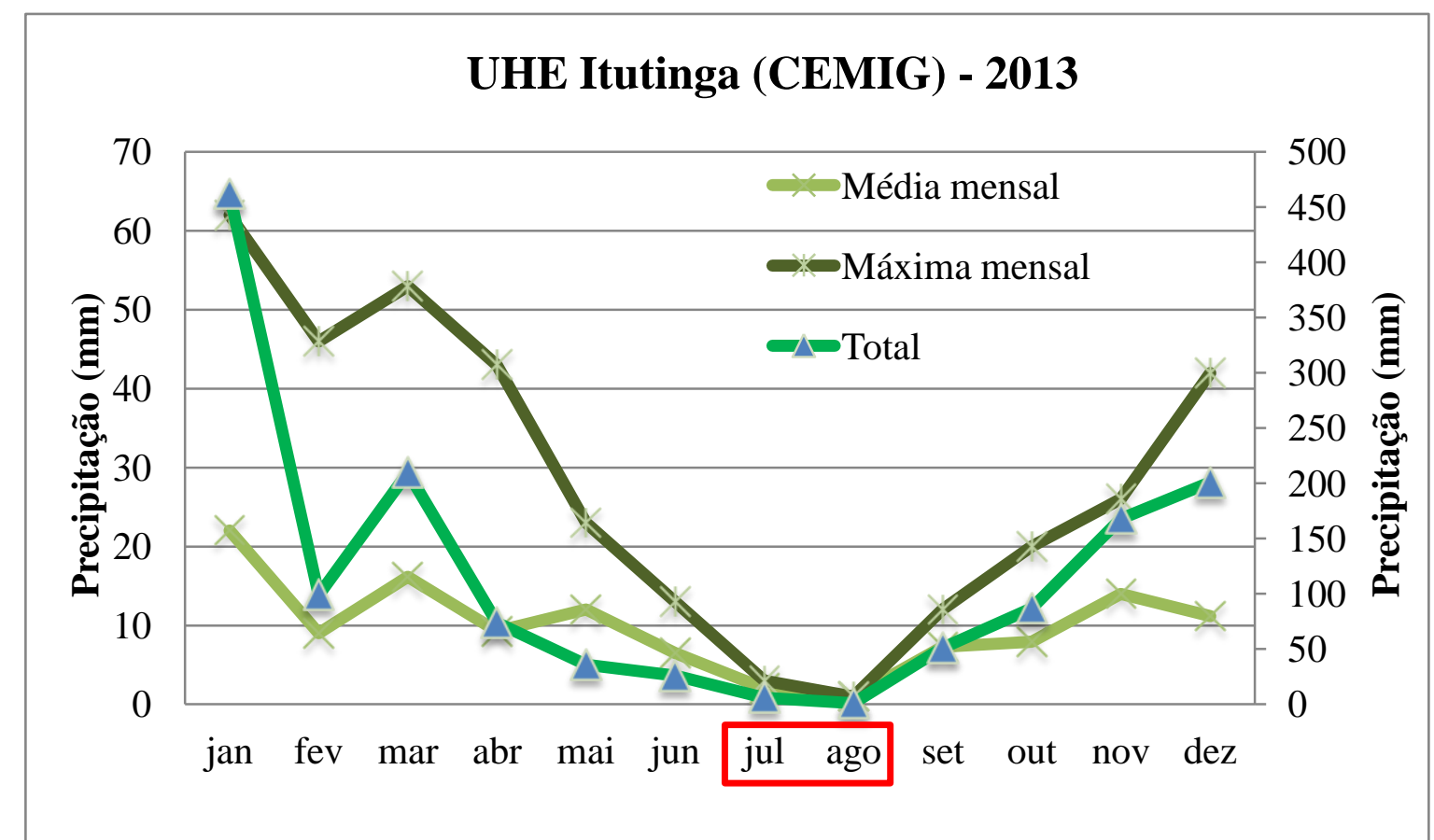

Gráfico 6 - Precipitações média e máxima mensal no eixo à esquerda, e precipitação total no mês no eixo à direita, para o ano de 2013. A marcação em vermelho indica os meses nos quais faltam dados (UHE Itutinga CEMIG).

\subsection{Uso e Ocupação}

Como visto até agora, a bacia do Alto Rio Grande possui muitas características naturais favoráveis ao desenvolvimento de processos erosivos, como grande variedade de rochas metamorfizadas, com xistosidades e bandamentos, além de falhas e zonas de cisalhamento que expõem estes materiais a uma situação de maior fragilidade. Estas rochas originaram os tipos de solos encontrados, como os Cambissolos: profundos com elevados teores de silte e argila, favoráveis ao encrostamento e pouco drenados, geralmente situados em relevos bastante movimentados, que, com a elevada pluviosidade e exposição à erosividade das chuvas, são muito susceptíveis à erosão hídrica, em especial, ao voçorocamento. A despeito desse conhecimento, a utilização destas terras pela atividade humana, historicamente, aparenta não levá-lo em muita consideração. A exploração de diversos recursos naturais deixaram cicatrizes irreversíveis ao longo dos anos.

A região de Nazareno, em adição aos municípios de São Tiago, Cassiterita, São João Del Rei, Ritápolis e Coronel Xavier Chaves, tiveram na mineração de ouro, na época colonial 
(COELHO, 1942 apud PEREIRA; ÁVILA; NEUMANN, 2004), na exploração do manganês, estanho e tântalo, e na atualidade, a concentração de tântalo (tantalita e microlita) e de estanho (cassiterita) (PEREIRA; ÁVILA; NEUMANN, 2004) suas principais fontes de extração de recursos minerais. Este tipo de atividade, juntamente com o desmatamento próximo às áreas urbanas, a ação do clima e conformação do relevo, segundo Silva (1990), Ferreira (2005), Silva et al. (2005 apud Ferreira et al., 2011), foram decisivos no surgimento dos processos erosivos, como as voçorocas, que ocorrem nesta região.

A origem de mais da metade das voçorocas do município de Nazareno também é atribuída à abertura de estradas, que foram construídas no sentido de maior escoamento superficial do declive, realizadas com as obras de drenagem com concentração em poucos pontos da encosta, e que eram utilizadas por carroças, que compactavam o solo e abriam muitos sulcos; após o surgimento desses processos erosivos, tinham sua localização deslocada, o que causava o aumento das dimensões das voçorocas. Em adição, as áreas de empréstimo utilizadas para as obras expuseram alguns horizontes subsuperficiais, o que, neste caso, aumenta a fragilidade da área em relação ao arraste de materiais menos resistentes (SILVA, 1990; FERREIRA, 2005).

Também se observa a presença de pastagens em locais com pobreza química do solo, que podem tanto causar a exposição de horizontes mais susceptíveis com a realização da queima, como causar a compactação pelo pisoteio nas trilhas utilizadas pelo gado, aumentando o escoamento superficial (HORTA, 2006; FERREIRA et al., 2007; FERREIRA et al., 2011).

Além desses fatores, o uso inadequado do solo, tanto em áreas urbanas, com ocupação descuidada, como nas áreas rurais, com a prática de abertura de valos para limitar as propriedades rurais, com o desmatamento, e com as atividades agrícolas realizadas de maneira a não conservar o equilíbrio do solo (SILVA, 1990; FERREIRA, 2005; FERREIRA et al., 2011), retorna como efeito sua própria inutilização com os processos erosivos. Mesmo com mais de 10 anos de conscientização populacional, de pesquisas realizadas na área e de tentativas de reversão deste cenário, os efeitos ainda podem ser observados e sentidos pelo município.

A Figura 27 mostra região próxima à cidade de Nazareno em 1985 e em 2007. Nestas imagens nota-se que poucas mudanças ocorreram em relação à expansão urbana e que, 
próxima à voçoroca do Córrego do Cravo (indicada pela seta), observa-se expansão da agricultura (cafeicultura). No restante, verifica-se a predominância de atividades rurais, como pastagens e culturas, e a presença de voçorocas de grande porte, demonstrando que estes processos são ainda cicatrizes para a região. Silva (1990) já alertava que “(...) a prevenção constitui a melhor maneira de se livrar do problema, pois uma vez instalada a erosão, torna-se inviável sua eliminação (...)”. 


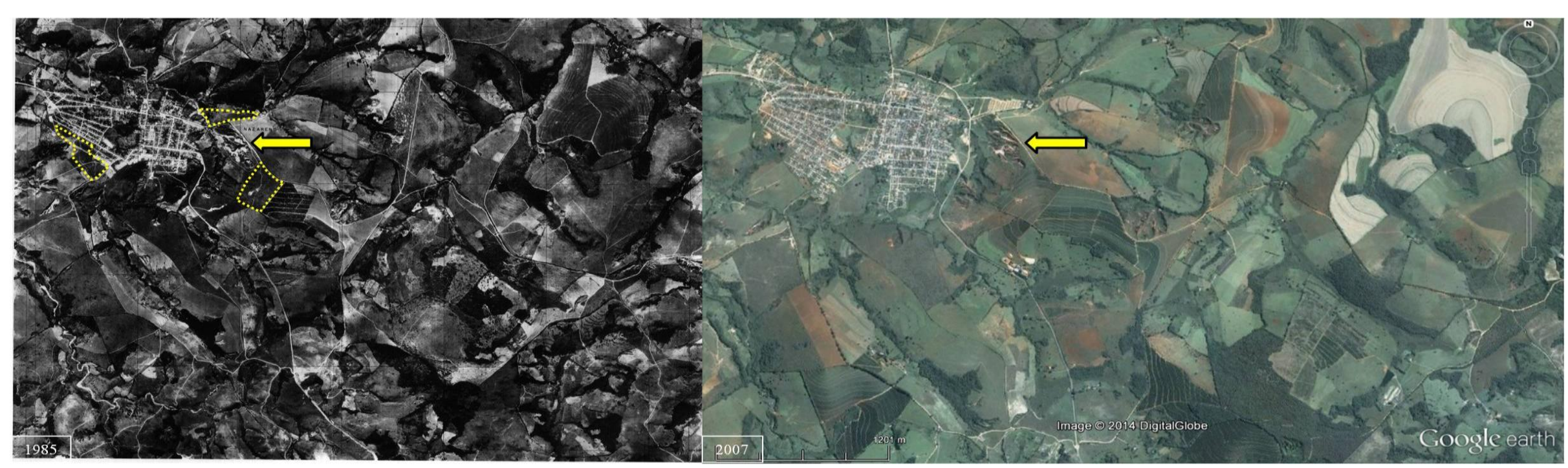

Figura 27 - Região próxima à cidade de Nazareno. Ortofotocarta da CEMIG, de 1985, em escala 1:10.000 à esquerda; imagem de 2007, à direita. As setas amarelas indicam a voçoroca do Córrego do Cravo, e as linhas pontilhadas amarelas indicam a expansão urbana e da cultura entre esses anos, para a região próxima a essa voçoroca. 


\section{MATERIAIS E MÉTODOS}

\subsection{Levantamento de Dados e Campanha de Campo}

Primeiramente, foi realizado levantamento dos dados sobre o município de Nazareno, Minas Gerais, onde foi possível obter informações quanto às características do meio físico e a problemática das voçorocas na região.

Neste levantamento inicial dos dados, realizado em outubro de 2011, teve-se o primeiro contato com o Projeto Maria de Barro, e com os trabalhos de recuperação realizados pelos integrantes desta ONG. Um destes trabalhos de recuperação foi realizado na voçoroca do Córrego do Cravo (objeto de estudo). As Figuras 28 e 29 apresentam a voçoroca do Córrego do Cravo em 2010, durante uma das últimas etapas de recuperação realizadas pelo Projeto Maria de Barro.

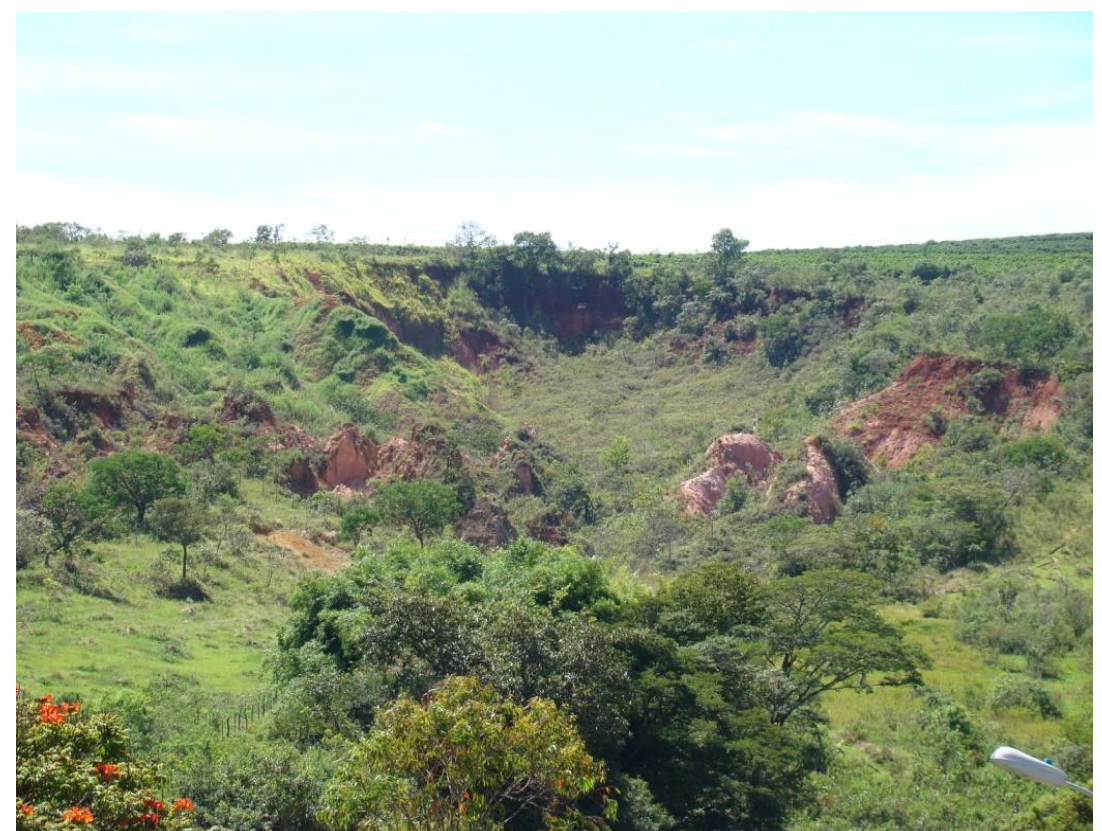

Figura 28 - Vista geral da voçoroca do Córrego do Cravo em 2010, durante atividades de recuperação. Imagem cedida pelo Projeto Maria de Barro. 


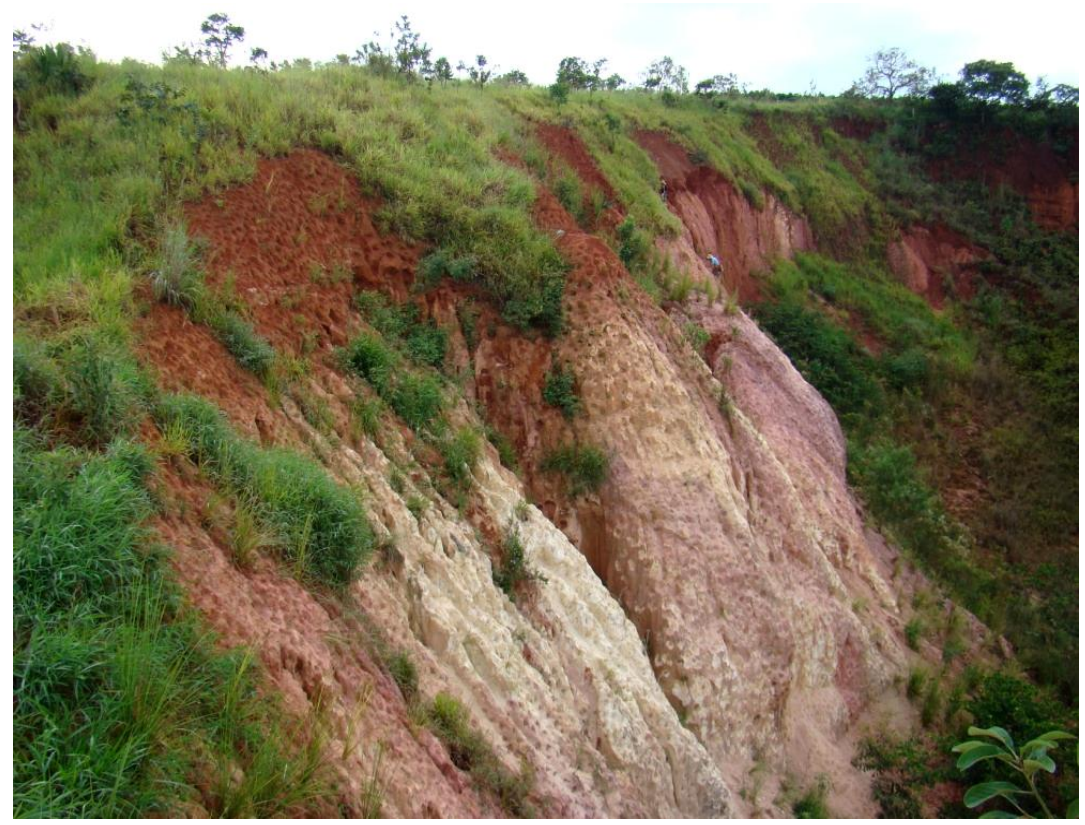

Figura 29 - Coveamento na voçoroca do Córrego do Cravo, em 2010. Imagem cedida pelo Projeto Maria de Barro.

Ainda durante estes levantamentos, teve-se a informação da ocorrência de dois deslizamentos após eventos pluviométricos intensos, no ano de 2012, na voçoroca do Córrego do Cravo. No ano de 2012, também ocorreu um incêndio nesta mesma voçoroca, gerando exposição dos solos (anteriormente recuperados).

Em decorrência de todo este histórico, a voçoroca do Córrego do Cravo foi escolhida, dentre as inúmeras erosões existentes em Nazareno, para o desenvolvimento desta pesquisa. Assim, foi realizada campanha de campo de reconhecimento da área em setembro de 2012. Nesta campanha de campo foi possível observar a semelhança de condições ambientais entre algumas voçorocas do município de Nazareno, além de verificar a existência de alguns pontos de instabilização e remobilização de material na voçoroca do Córrego do Cravo. A Figura 30 exibe os escorregamentos e as condições após o incêndio na voçoroca do Córrego do Cravo (em 2012). 

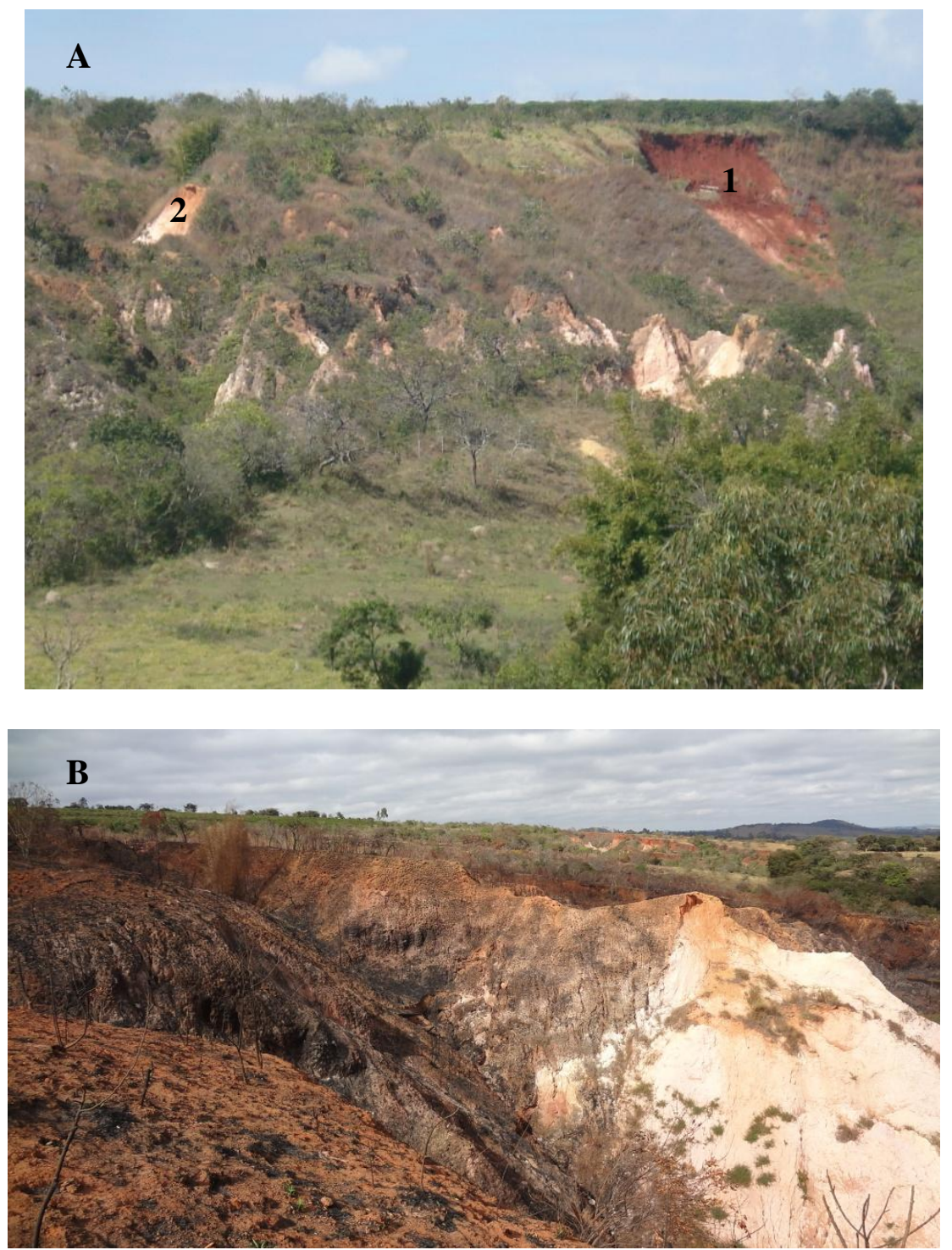

Figura 30 - A) Vista da voçoroca do Córrego do Cravo com o escorregamento circular ou rotacional (1) e planar ou translacional (2), em julho de 2012 (OLIVEIRA, no prelo); B) Vista de parte da voçoroca do Córrego do Cravo em setembro de 2012, com destaque para o deslizamento translacional à frente.

Em julho de 2013 foi realizada outra campanha de campo na voçoroca do Córrego do Cravo, visando à coleta de dados e amostras. As Figuras 31 e 32 apresentam uma visão da voçoroca do Córrego do Cravo, em julho de 2013. 


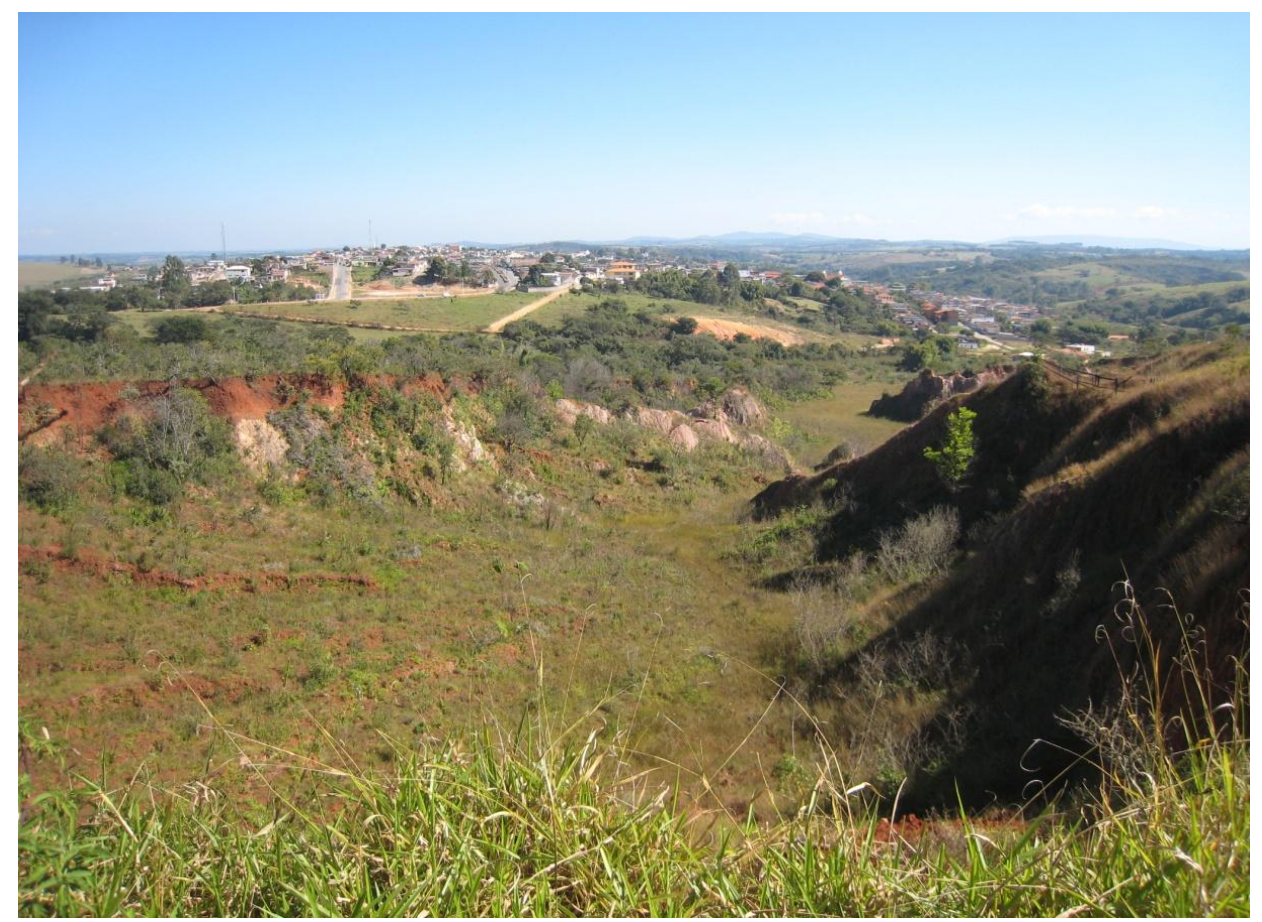

Figura 31 - Vista de cima da voçoroca do Córrego do Cravo (montante), com a cidade de Nazareno ao fundo (julho de 2013).

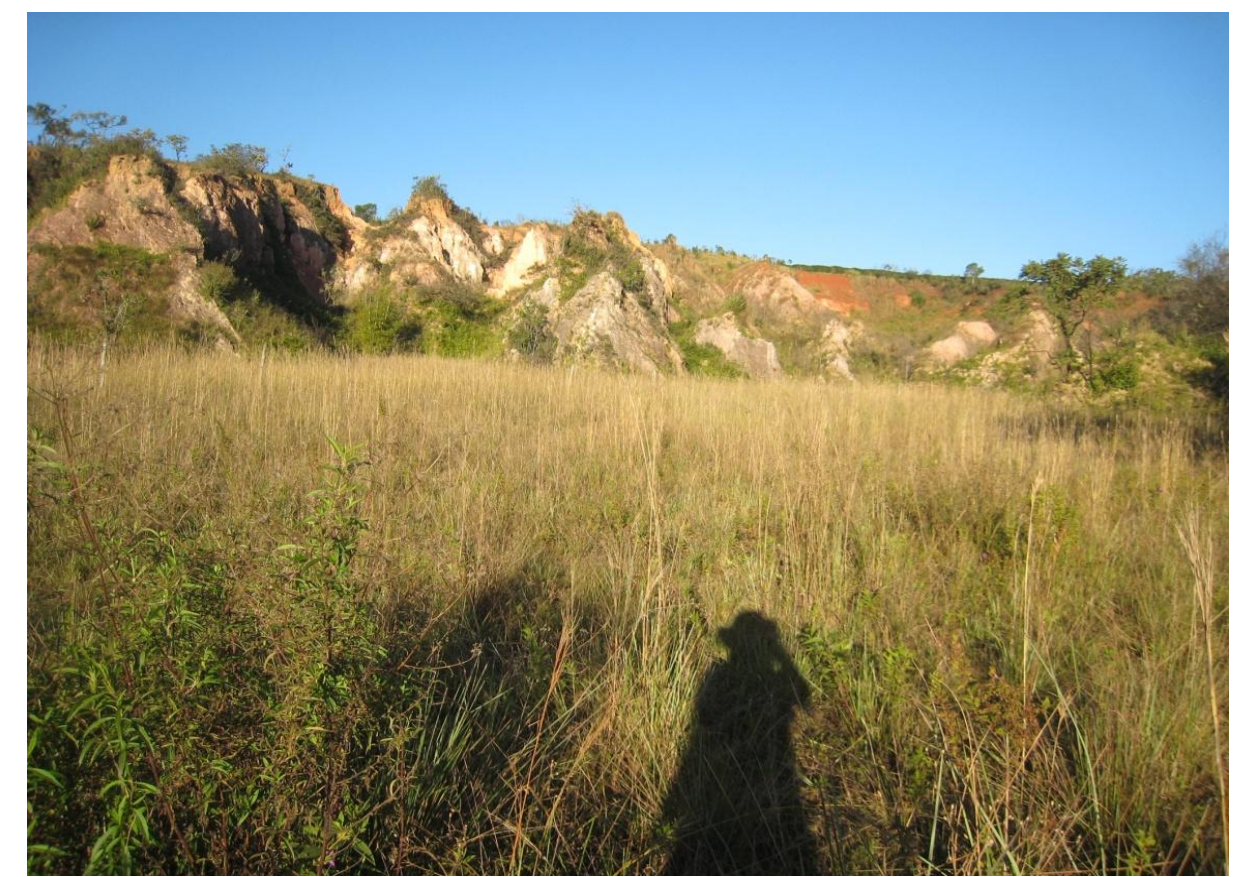

Figura 32 - Vista da parte interna da voçoroca do Córrego do Cravo (julho de 2013).

Na campanha de campo realizada em 2013 foi realizado caminhamento em todo o entorno da voçoroca do Córrego do Cravo, e, através do uso de topofio, trena (Figura 33), clinômetro Suunto e GPS, foi possível medir seu perímetro aproximado e a profundidade de alguns de seus braços. As coordenadas dos pontos de caminhamento juntamente com as 
medidas das profundidades dos braços são apresentadas na Tabela 10. O mapa de caminhamento (Anexo 01) exibe a localização dos pontos e o caminhamento realizado na voçoroca do Córrego do Cravo.

Tabela 10 - Dados referentes ao caminhamento realizado na voçoroca do Córrego do Cravo.

\begin{tabular}{|c|c|c|c|c|}
\hline Ponto & $\begin{array}{l}\text { Coordenadas } \\
\text { UTM (m) }\end{array}$ & Altitude (m) & $\begin{array}{c}\text { Profundidade do } \\
\text { Braço da } \\
\text { Voçoroca }(\mathbf{m})\end{array}$ & $\begin{array}{c}\text { Ângulo } \\
\text { Medido no } \\
\text { Braço da } \\
\text { Voçoroca }\end{array}$ \\
\hline 01 & $\begin{array}{c}540876 \\
7653711\end{array}$ & 907 & ND & ND \\
\hline 02 & $\begin{array}{c}541105 \\
7653193 \\
\end{array}$ & 979 & ND & ND \\
\hline 03 & $\begin{array}{c}541049 \\
7653202\end{array}$ & 965 & 13,90 & $44^{\circ}$ \\
\hline 04 & $\begin{array}{c}540984 \\
7653268\end{array}$ & 956 & 14,20 & $43^{\circ}$ \\
\hline 05 & $\begin{array}{c}540981 \\
7653266\end{array}$ & 942 & ND & ND \\
\hline 06 & $\begin{array}{c}540897 \\
7653313 \\
\end{array}$ & 940 & 11,50 & $47^{\circ}$ \\
\hline 07 & $\begin{array}{c}540855 \\
7653384\end{array}$ & 939 & 10,30 & $32^{\circ}$ \\
\hline 08 & $\begin{array}{c}540840 \\
7653436\end{array}$ & 925 & ND & ND \\
\hline 09 & $\begin{array}{c}541129 \\
7653259\end{array}$ & 936 & ND & ND \\
\hline 10 & $\begin{array}{c}541085 \\
7653290\end{array}$ & 934 & ND & ND \\
\hline 11 & $\begin{array}{c}541080 \\
7653302\end{array}$ & 952 & ND & ND \\
\hline 12 & $\begin{array}{c}541060 \\
7653306 \\
\end{array}$ & 929 & ND & ND \\
\hline 13 & $\begin{array}{c}541080 \\
7653302 \\
\end{array}$ & 952 & ND & ND \\
\hline 14 & $\begin{array}{c}541088 \\
7653325\end{array}$ & 933 & ND & ND \\
\hline 15 & $\begin{array}{c}541064 \\
7653333 \\
\end{array}$ & 930 & 26,00 & ND \\
\hline 16 & $\begin{array}{c}541054 \\
7653335 \\
\end{array}$ & 964 & ND & ND \\
\hline 17 & $\begin{array}{c}541042 \\
7653331\end{array}$ & 961 & 13,00 & ND \\
\hline 18 & $\begin{array}{c}541080 \\
7653333\end{array}$ & 968 & ND & ND \\
\hline 19 & $\begin{array}{c}541064 \\
7653345\end{array}$ & 960 & ND & ND \\
\hline 20 & $\begin{array}{c}541055 \\
7653381\end{array}$ & 956 & ND & ND \\
\hline
\end{tabular}


Tabela 10 - Dados referentes ao caminhamento realizado na voçoroca do Córrego do Cravo (continuação).

\begin{tabular}{|c|c|c|c|c|}
\hline Ponto & $\begin{array}{l}\text { Coordenadas } \\
\text { UTM (m) }\end{array}$ & Altitude (m) & $\begin{array}{c}\text { Profundidade do } \\
\text { Braço da } \\
\text { Voçoroca }(\mathbf{m})\end{array}$ & $\begin{array}{c}\text { Ângulo } \\
\text { Medido no } \\
\text { Braço da } \\
\text { Voçoroca } \\
\end{array}$ \\
\hline B1 (21) & $\begin{array}{c}541076 \\
7653386\end{array}$ & 961 & ND & ND \\
\hline 22 & $\begin{array}{c}541048 \\
7653439\end{array}$ & 955 & ND & ND \\
\hline 23 & $\begin{array}{c}541073 \\
7653430\end{array}$ & 955 & ND & ND \\
\hline 24 & $\begin{array}{c}540988 \\
7653468\end{array}$ & 944 & ND & ND \\
\hline 25 & $\begin{array}{c}540927 \\
7653468\end{array}$ & 939 & ND & ND \\
\hline 26 & $\begin{array}{c}540955 \\
7653558\end{array}$ & 936 & ND & ND \\
\hline 27 & $\begin{array}{c}540968 \\
7653585 \\
\end{array}$ & 946 & ND & ND \\
\hline 28 & $\begin{array}{c}540943 \\
7653601\end{array}$ & 944 & ND & ND \\
\hline 29 & $\begin{array}{c}540867 \\
7653636\end{array}$ & 934 & ND & ND \\
\hline 30 & $\begin{array}{c}540853 \\
7653670\end{array}$ & 932 & ND & ND \\
\hline 31 & $\begin{array}{c}541082 \\
7653444\end{array}$ & 946 & ND & ND \\
\hline 32 & $\begin{array}{c}541046 \\
7653459\end{array}$ & 906 & ND & ND \\
\hline B2 (33) & $\begin{array}{c}541055 \\
7653513\end{array}$ & 940 & ND & ND \\
\hline 34 & $\begin{array}{c}540981 \\
7653547\end{array}$ & 932 & ND & ND \\
\hline
\end{tabular}

B1 e B2: Barraginhas do Projeto Maria de Barro

ND: Não determinado.

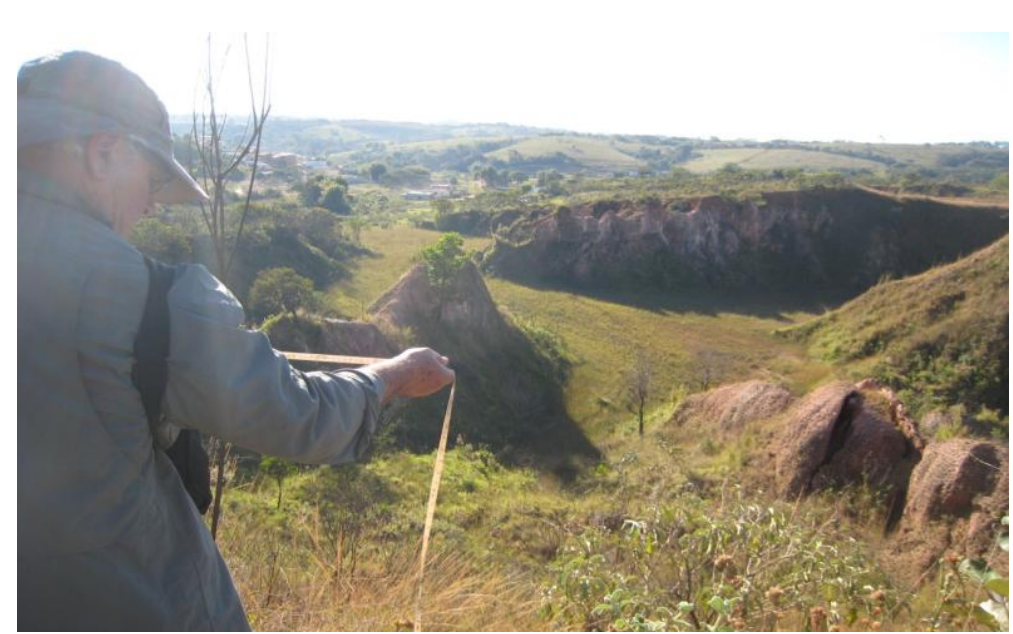

Figura 33 - Medição da profundidade de um braço da voçoroca do Córrego do Cravo, em Nazareno/MG. 
Durante o caminhamento, foram observadas as características do solo (contato entre o Latossolo e Saprolito "Figura 34" e variações de textura, estrutura e cor "Figuras 35"), litologia, intemperismo e presença de sulcos e pipings (Figura 36) e, diante da diversidade encontrada, foram coletadas amostras em pontos distintos visando verificar a variabilidade de materiais. As amostras de Latossolos foram denominadas de LAT e a de Saprolito de SAP.

A coleta foi realizada nos pontos de maior facilidade de acesso, pois essa área é muito íngreme e instável.

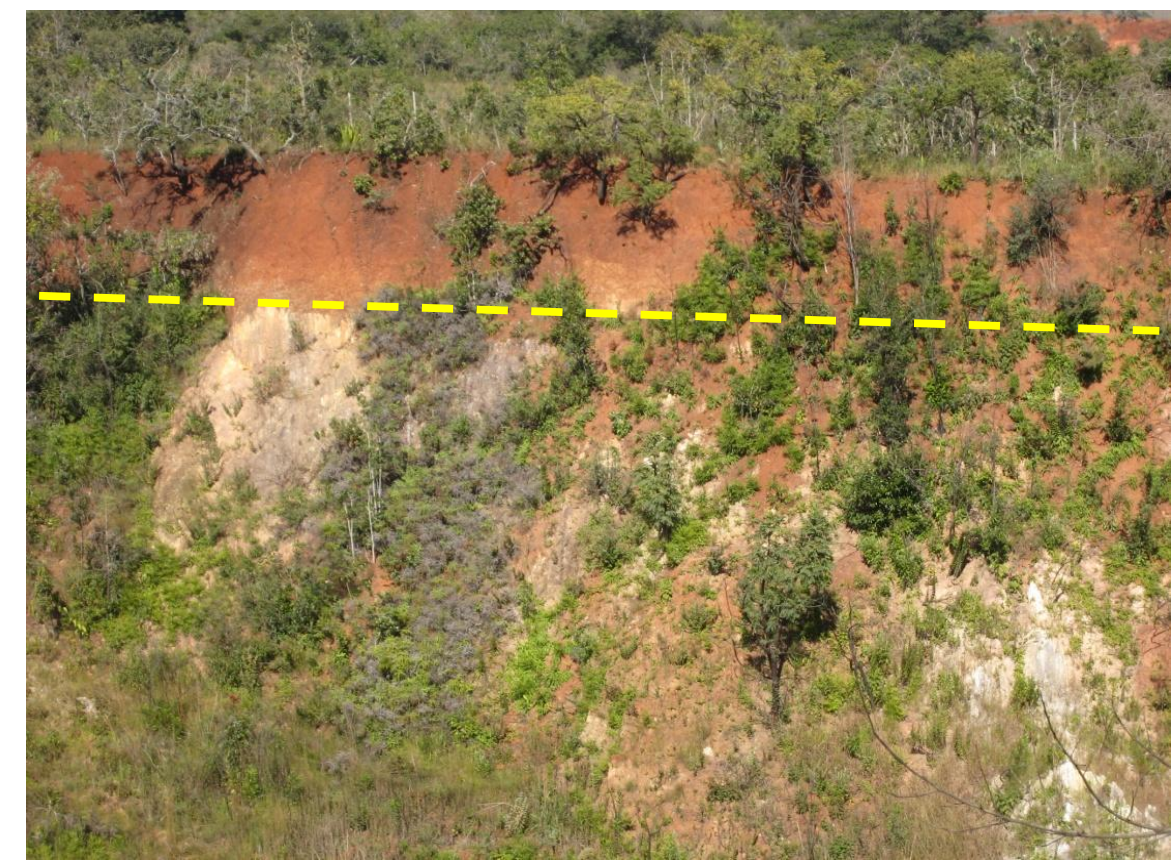

Figura 34 - Contato entre o Latossolo (porção superior) e o Saprolito (porção inferior, mais clara) - Voçoroca do Córrego do Cravo. 


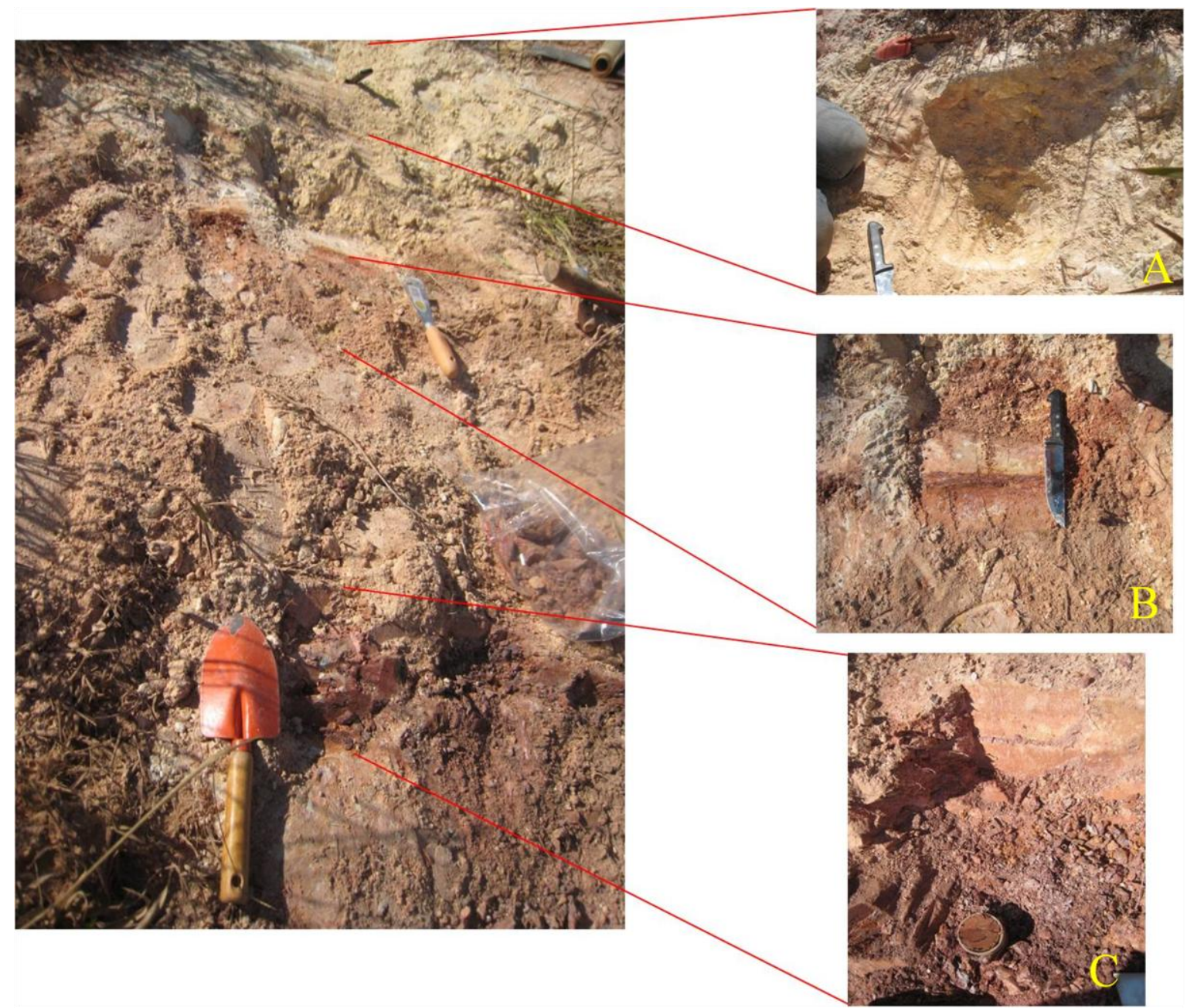

Figura 35 - Variabilidade das características do solo. A) Solo mais quartzoso (aspecto sacaroidal), B) Solo mais claro (pouco coeso) e C) Solo com xistosidade (material mais escuro).

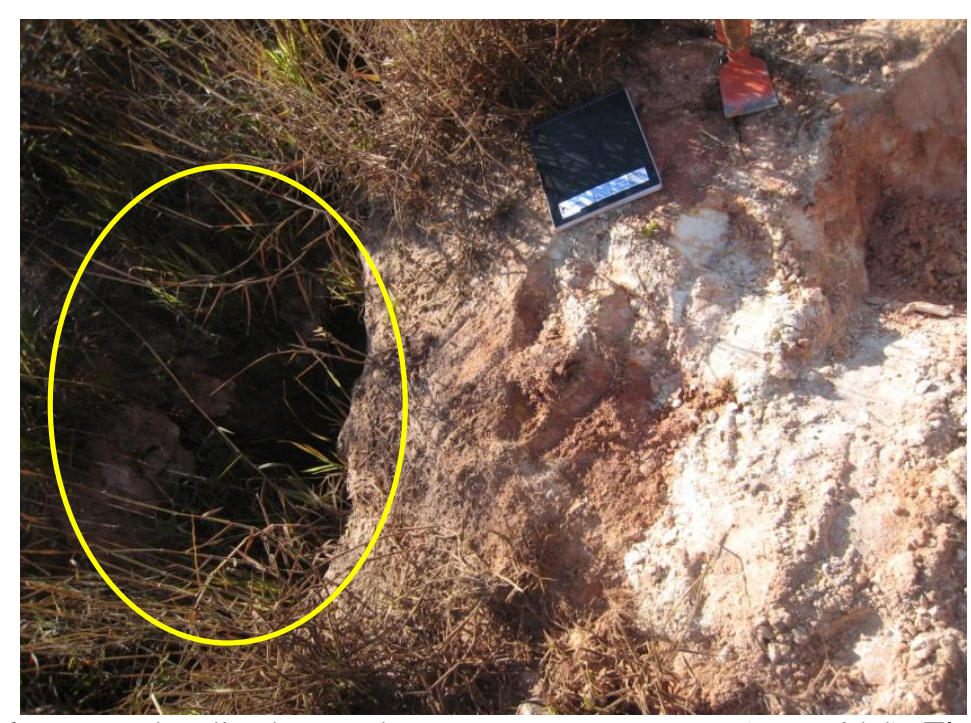

Figura 36 - Piping localizado no solo com aspecto quartzoso (sacaroidal) (Figura 35A). 
Para caracterização geológica e geotécnica dos materiais que compõem a voçoroca, foram coletadas amostras deformadas e indeformadas. O Anexo 02 exibe os pontos de amostragem ao longo da voçoroca do Córrego do Cravo e a Tabela 11 apresenta descrição detalhada das amostras e dos locais de coleta.

Os solos deformados foram coletados a partir do emprego de uma pá e foram armazenados em sacos plásticos.

As amostras indeformadas foram coletadas para os ensaios de permeabilidade (Figuras 37A) e erodibilidade (Figura 37B), a partir do emprego de tubo de PVC de diferentes alturas $(9,0 \mathrm{~cm}$ para o ensaio de permeabilidade e $2,0 \mathrm{~cm}$ para o de erodibilidade) e diâmetros $(9,7 \mathrm{~cm}$ para permeabilidade e $5,0 \mathrm{~cm}$ para erodibilidade). Estas amostras, no campo, foram envoltas em papel filme, sendo armazenadas em isopor com serragem para o transporte seguro das mesmas. 
Tabela 11 - Detalhamento dos pontos de coleta - Voçoroca do Córrego do Cravo - Nazareno/MG.

\begin{tabular}{|c|c|c|c|c|}
\hline $\begin{array}{l}\text { Ponto de } \\
\text { Coleta }\end{array}$ & $\begin{array}{c}\text { Coordenadas } \\
\text { UTM e } \\
\text { Altitude }\end{array}$ & $\begin{array}{c}\text { Tipos de } \\
\text { Amostragem }\end{array}$ & $\begin{array}{c}\text { Observação em } \\
\text { Campo }\end{array}$ & Imagem \\
\hline LAT 1 & $\begin{array}{l}0541118 \\
7653235 \\
911 \mathrm{~m}\end{array}$ & $\begin{array}{c}\text { Coleta } \\
\text { deformada }\end{array}$ & $\begin{array}{c}\text { Latossolo: Amostra } \\
\text { coletada em encosta } \\
\text { com movimento de } \\
\text { massa. } \\
\text { Coloração marrom } \\
\text { escura - muito friável } \\
\text { - presença de fissuras } \\
\text { e raízes no talude }\end{array}$ & \\
\hline LAT T 2 & $\begin{array}{c}0541144 \\
7653249 \\
952 \mathrm{~m}\end{array}$ & $\begin{array}{c}\text { Coleta } \\
\text { deformada }\end{array}$ & $\begin{array}{l}\text { Latossolo: Amostra } \\
\text { coletada em uma } \\
\text { trincheira (porção } \\
\text { superior). } \\
\text { Coloração marrom } \\
\text { escura - menos } \\
\text { friável que a amostra } \\
\text { LAT 1 - } \\
\text { Concreções }\end{array}$ & \\
\hline LAT T 3 & $\begin{array}{c}0541144 \\
7653249 \\
952 \mathrm{~m}\end{array}$ & $\begin{array}{c}\text { Coleta } \\
\text { deformada; } \\
\text { Indeformadas: } \\
\text { erodibilidade, } \\
\text { condutividade } \\
\text { hidráulica }\end{array}$ & $\begin{array}{l}\text { Latossolo: Amostra } \\
\text { coletada em uma } \\
\text { trincheira (porção } \\
\text { inferior). } \\
\text { Coloração marrom } \\
\text { escura - mais friável } \\
\text { que os solos LAT } 1 \text { e } \\
\text { LAT T } 2\end{array}$ & \\
\hline SAP 1 & $\begin{array}{c}0541110 \\
7653258 \\
898 \mathrm{~m}\end{array}$ & $\begin{array}{l}\text { Coleta } \\
\text { deformada; } \\
\text { Indeformada: } \\
\text { erodibilidade }\end{array}$ & $\begin{array}{l}\text { Saprolito (provável } \\
\text { alteração do gnaisse- } \\
\text { migmatito): } \\
\text { Coloração variegada } \\
\text { (mais próximo do } \\
\text { rosa) - friável - } \\
\text { presença de minerais } \\
\text { miloníticos alongados } \\
\text { no talude }\end{array}$ & \\
\hline SAP 2 & $\begin{array}{c}0541038 \\
7653350 \\
897 \mathrm{~m}\end{array}$ & $\begin{array}{l}\text { Coleta } \\
\text { deformada; } \\
\text { Indeformada: } \\
\text { erodibilidade }\end{array}$ & $\begin{array}{l}\text { Solo saprolítico: } \\
\text { Média friabilidade - } \\
\text { Coloração marrom } \\
\text { clara - presença de } \\
\text { muitas raízes e } \\
\text { fissuras } \\
\text { Obs: solo de } \\
\text { transição entre LAT e } \\
\text { SAP }\end{array}$ & \\
\hline SAP TX 3 & $\begin{array}{c}0541055 \\
7653381 \\
956 \mathrm{~m}\end{array}$ & $\begin{array}{l}\text { Coleta } \\
\text { deformada; } \\
\text { Indeformada: } \\
\text { erodibilidade }\end{array}$ & $\begin{array}{c}\text { Solo saprolítico } \\
\text { (alteração do talco- } \\
\text { xisto): } \\
\text { Foliações do talco- } \\
\text { xisto - material com } \\
\text { elevado grau de } \\
\text { alteração - presença } \\
\text { de raízes }\end{array}$ & \\
\hline
\end{tabular}


Tabela 11 - Detalhamento dos pontos de coleta - Voçoroca do Córrego do Cravo - Nazareno/MG (continuação).

\begin{tabular}{|c|c|c|c|c|}
\hline $\begin{array}{l}\text { Ponto de } \\
\text { Coleta }\end{array}$ & $\begin{array}{c}\text { Coordenadas } \\
\text { UTM e } \\
\text { Altitude }\end{array}$ & $\begin{array}{c}\text { Tipos de } \\
\text { Amostragem }\end{array}$ & $\begin{array}{c}\text { Observação em } \\
\text { Campo }\end{array}$ & Imagem \\
\hline SAP TX 4 & $\begin{array}{c}0541058 \\
7653398 \\
909 \mathrm{~m}\end{array}$ & $\begin{array}{c}\text { Coleta } \\
\text { deformada }\end{array}$ & $\begin{array}{c}\text { Solo saprolítico } \\
\text { (alteração do talco- } \\
\text { xisto): } \\
\text { Presença de } \\
\text { estruturas reliquiares } \\
\text { - material com } \\
\text { elevado grau de } \\
\text { alteração } \\
\end{array}$ & \\
\hline SAP P 5 & $\begin{array}{c}0541046 \\
7653459 \\
906 \mathrm{~m}\end{array}$ & $\begin{array}{l}\text { Coleta } \\
\text { deformada; } \\
\text { Indeformada: } \\
\text { erodibilidade }\end{array}$ & $\begin{array}{c}\text { Saprolito (localizado } \\
\text { próximo ao piping, } \\
\text { Figura 35A): } \\
\text { Coloração branca, } \\
\text { com lentes } \\
\text { amareladas - aspecto } \\
\text { sacaroidal - quartzoso }\end{array}$ & \\
\hline SAP P 6 & $\begin{array}{c}0541046 \\
7653459 \\
906 \mathrm{~m}\end{array}$ & $\begin{array}{l}\text { Coleta } \\
\text { deformada; } \\
\text { Indeformada: } \\
\text { erodibilidade }\end{array}$ & $\begin{array}{l}\text { Saprolito (localizado } \\
\text { próximo ao piping, } \\
\text { Figura 35C): } \\
\text { Coloração vermelho- } \\
\text { arroxeada - pouco } \\
\text { friável - com } \\
\text { presença de } \\
\text { estruturação - } \\
\text { foliações }\end{array}$ & \\
\hline SAP P 7 & $\begin{array}{c}0541046 \\
7653459 \\
906 \mathrm{~m}\end{array}$ & $\begin{array}{l}\text { Coleta } \\
\text { deformada; } \\
\text { Indeformadas: } \\
\text { erodibilidade; } \\
\text { condutividade } \\
\text { hidráulica }\end{array}$ & $\begin{array}{l}\text { Saprolito (localizado } \\
\text { próximo ao piping da } \\
\text { Figura 35B): } \\
\text { Coloração } \\
\text { predominantemente } \\
\text { rosa, porém, com } \\
\text { algumas lentes } \\
\text { amareladas e brancas }\end{array}$ & \\
\hline SAP P8 & $\begin{array}{c}0541046 \\
7653459 \\
906 \mathbf{m}\end{array}$ & $\begin{array}{l}\text { Coleta } \\
\text { deformada; } \\
\text { Indeformada: } \\
\text { erodibilidade. }\end{array}$ & $\begin{array}{l}\text { Saprolito (localizado } \\
\text { próximo ao piping da } \\
\text { Figura 35B): } \\
\text { Friável - coloração } \\
\text { branca e rosa, com } \\
\text { lentes amareladas }\end{array}$ & \\
\hline
\end{tabular}




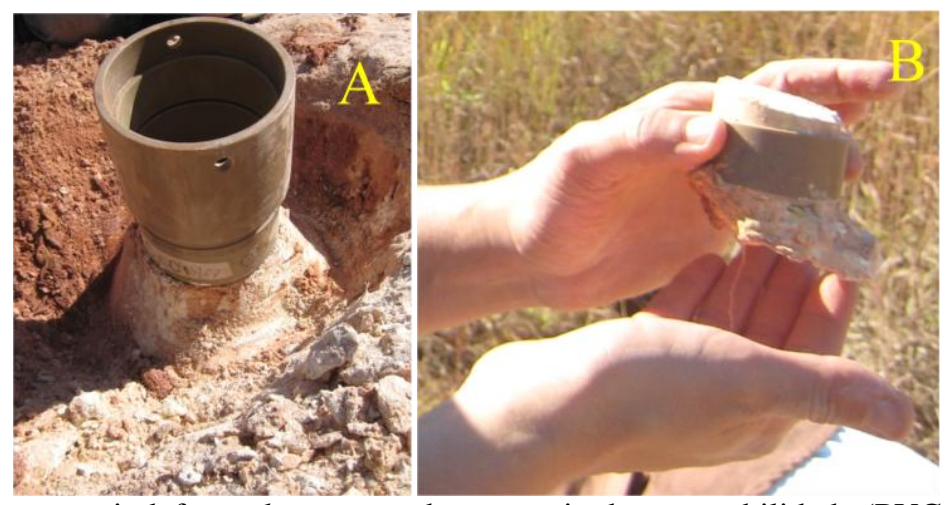

Figura 37 - A) Amostra indeformada empregada no ensaio de permeabilidade (PVC de $9 \mathrm{~cm}$ de altura); B) Amostra indeformada retirada para o ensaio de erodibilidade (PVC de $2 \mathrm{~cm}$ de altura).

Os Latossolos (LAT T2 e T3) foram coletados em uma área próxima ao cafezal, sendo que foi necessário abrir uma trincheira de $80 \mathrm{~cm}$, para retirada de amostras indeformadas sem a presença de raízes (Figura 38). No interior desta trincheira, também foram coletadas amostras deformadas. O solo LAT T2 corresponde à porção superior do perfil e o LAT T3 à inferior.

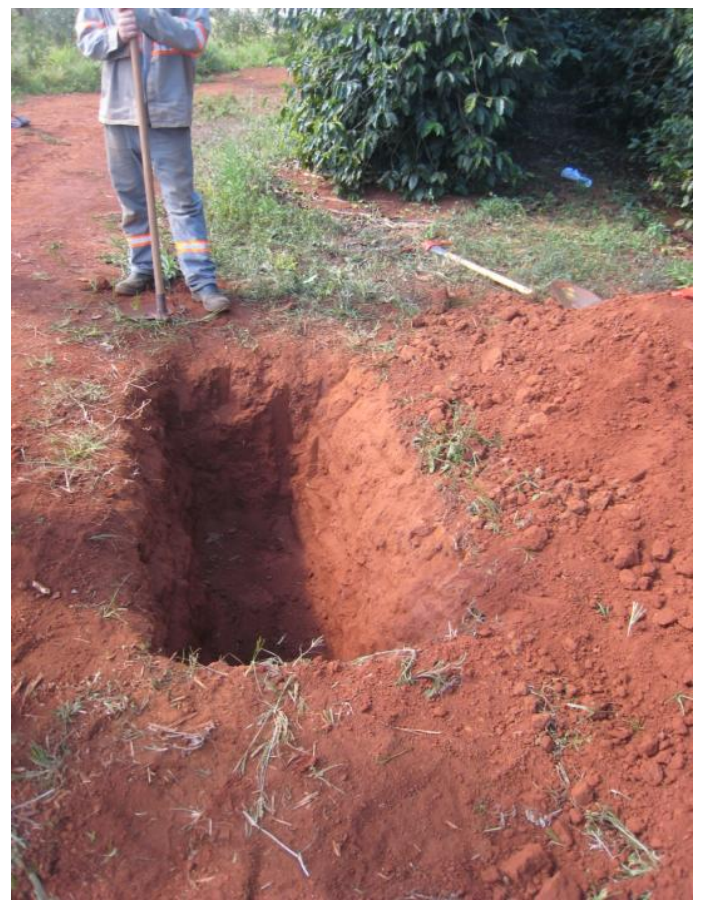

Figura 38 - Trincheira de $80 \mathrm{~cm}$ aberta em solo laterítico, próxima ao cafezal, coleta de amostras indeformadas e deformadas.

No caso desta pesquisa, as amostras utilizadas foram as de maior representatividade entre os Latossolos e o Saprolito (granito-gnaisse). 


\subsection{Uso de SIG - ArcGIS ${ }^{\circledR}$}

Nesta etapa do trabalho, utilizou-se a folha de Nazareno (SF-23-X-C-I-2) do Instituto Brasileiro de Geografia e Estatística (IBGE) de 1975, como base para a obtenção de diversos mapas. O software empregado na elaboração dos mapas foi o $\operatorname{ArcGIS}^{\circledR}\left(\operatorname{ArcMAP}^{T M}\right)$.

No software $E N V I^{T M}$, foi realizado o georreferenciamento dos dados, utilizando-se Projeção Universal Transversa de Mercator (UTM), Dátum Horizontal Córrego Alegre (MG) e Zona $23 \mathrm{~S}$.

A Folha Nazareno se apresenta com curvas de nível de 20 em 20 metros e na escala de 1:50.000. As curvas de nível, assim como os pontos cotados, os cursos d'água, a área urbana e as estradas, foram digitalizados em formatos shapefile no $A r c G I S^{\circledR}$. Para realização de uma análise mais apurada para a voçoroca do Córrego do Cravo, foi delimitada a bacia deste córrego a partir das informações da Folha Nazareno, pois atualmente a área está tomada por esta e outra voçoroca que alteraram a paisagem original desta bacia.

Foi obtido o Modelo Digital de Elevação (MDE), em formato raster, com a utilização de Topo to Raster da sequência Arctoolbox - 3D Analyst Tools - Raster Interpolation. Após este procedimento, realizou-se o preenchimento de depressões fechadas utilizando-se a sequência de comandos Arctoolbox - Spatial Analyst Tools - Hydrology - Fill. Também foi obtido o modelo sombreado do terreno com a sequência Arctoolbox - Spatial Analyst Tools Surface-Hillshade.

Através da ferramenta Reclassify de Arctoolbox - Spatial Analyst Tools - Reclass, foi possível reclassificar as altitudes do relevo desta bacia, obtendo-se, assim, um mapa de classes hipsométricas, e com a mesma ferramenta, realizou-se a reclassificação para a declividade criada a partir da ferramenta Slope de Arctoolbox - Spatial Analyst Tools Surface, criando-se, assim, um mapa de classes de declividades, divididas de acordo com Embrapa (2006c).

Além disso, para melhor entendimento do fluxo na área de estudo, foi gerado mapa de direção de fluxo, utilizando-se o comando Flow Direction da sequência Arctoolbox - Spatial Analyst Tools - Hydrology. Os números e cores utilizadas no mapa de direção de fluxo representam apenas o percurso que o escoamento tenderá a realizar (Figura 39). 


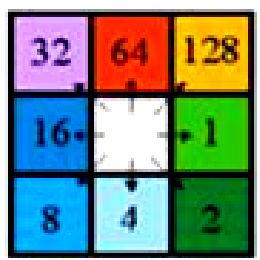

Figura 39 - Código de direção de fluxo, retirado do $A r c G I S^{\circledast}$.

Com a ferramenta Zonal Geometry as Table, do Spatial Analyst Tools, realizou-se o cálculo das áreas em que se encontravam cada altitude, declividade e cada direção de fluxo, para estudo da predominância de tais características na bacia.

Após estes procedimentos, verificou-se a necessidade de se obter curvas de nível com menor equidistância entre elas, pois a área da voçoroca é pequena em relação à bacia. Dessa forma, utilizou-se a ferramenta Contour da sequência Arctoolbox - Spatial Analyst Tools Surface, obtendo-se assim curvas de nível de 5 metros de equidistância.

Diante disso, foi possível obter a base para realização dos croquis, que, em conjunto com as informações obtidas em campo e em laboratório, serviram para avaliação das condições de drenagem superficial e subsuperficial da área, além de auxiliar a criação das propostas de obras para seu disciplinamento.

Neste caso, as coordenadas UTM dos pontos de caminhamento e coleta foram inseridas em uma tabela, em conjunto com os valores de altitude, sendo esta tabela adicionada ao $A r c G I S^{\circledR}$, carregando-se seus dados através da ferramenta Display XY Data. A partir das observações, anotações e fotografias do caminhamento foram construídos croquis para apresentação do caminhamento e das coletas, a partir de um croqui da situação atual desta bacia. Também com os croquis realizados foi possível delinear, de forma aproximada, o perímetro atual da voçoroca do Córrego do Cravo, sendo que, posteriormente, foram geradas duas seções, uma longitudinal (AB) e outra transversal (CD), para observação da distribuição dos solos e da conformação atual da voçoroca em contraste com a posição do relevo de acordo com a Folha Nazareno de 1975; as informações das quais não se dispunham de medições foram extrapoladas de acordo com as observações em campo (por exemplo, nível d'água aflorante ao fundo da voçoroca). 


\subsection{Ensaios em Laboratório}

\subsubsection{Ensaio de Condutividade Hidráulica a CARga Constante}

Este ensaio foi realizado segundo metodologia proposta por Daniel (1994) e ABNTNBR 13.292: Solo - Determinação do coeficiente de permeabilidade de solos granulares à carga constante, no Laboratório de Geotecnia do Departamento de Geotecnia da Escola de Engenharia de São Carlos (EESC-USP). Estas metodologias adotam a condutividade hidráulica como o coeficiente de proporcionalidade proposto por Henry Darcy em 1856 (Equação 13), conhecida como Lei de Darcy:

$$
q=k \cdot i . A=k \cdot \frac{\Delta H}{L} . A
$$

Em que, no Sistema Internacional de medidas, a vazão é dada por $q\left(\mathrm{~m}^{3} \cdot \mathrm{s}^{-1}\right)$, a condutividade hidráulica por $k\left(\mathrm{~m} . \mathrm{s}^{-1}\right)$, o gradiente hidráulico por $i$ (adimensional), o qual é composto pela relação entre a perda de carga sobre o corpo de prova, $\Delta H(\mathrm{~m})$, e o seu comprimento, $L(\mathrm{~m})$, e a área da seção transversal dada por $A\left(\mathrm{~m}^{2}\right)$, sendo esta perpendicular ao fluxo. A unidade tradicionalmente utilizada para a condutividade hidráulica é $\mathrm{cm} . \mathrm{s}^{-1}$ (DANIEL, 1994).

Para obtenção deste parâmetro, foi utilizado permeâmetro de parede rígida conforme a Figura 40. Neste caso, foram empregadas as amostras indeformadas coletadas no tubo de PVC maior (9 cm de altura). Para este estudo foi empregada amostra LAT T 3 e SAP P 7. 

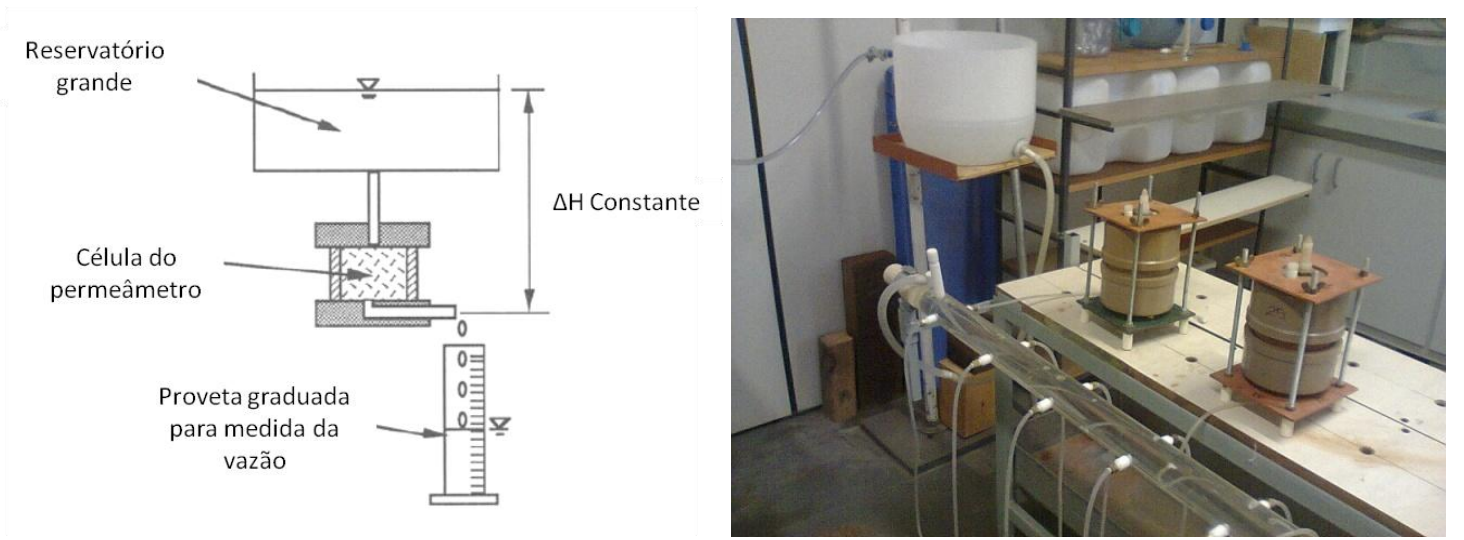

Figura 40 - Carga constante mantida com reservatório grande (Adaptado de DANIEL, 1994), à esquerda; ensaio de condutividade hidráulica a carga constante, à direita.

Este ensaio foi realizado com a carga constante, isto é, a perda de carga utilizada foi mantida igual a $27 \mathrm{~cm}$ durante todo o ensaio com o auxílio de uma bóia; foi realizada medição para a vazão de água da rede que fluiu na célula durante 1 minuto, sendo esta recolhida em provetas graduadas, anotando-se os volumes obtidos neste tempo. Estes dados foram utilizados na Equação (13) para obtenção da carga hidráulica dos solos amostrados.

\subsubsection{ENSAIO DE ERODIBILIDADE}

O ensaio de erodibilidade foi realizado conforme método proposto em Pejon (1992). Este ensaio foi realizado em conjunto com Maria Paula Pires de Oliveira no Laboratório de Geotecnia do Departamento de Geotecnia da EESC-USP.

Para este ensaio foram utilizadas as amostras indeformadas coletadas no tubo de PVC menor ( $2 \mathrm{~cm}$ de altura). Essas amostras, primeiramente, ficaram secando durante 7 dias; após este período o excesso de material foi raspado, e as mesmas foram colocadas em um suporte, conforme exibe a Figura 41. 


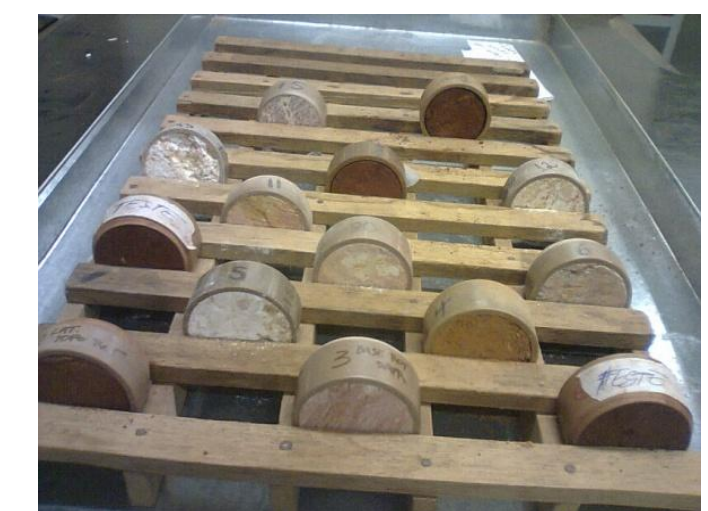

Figura 41 - Preparação dos anéis para ensaio de erodibilidade.

Após secagem, os anéis foram colocados, um a um, em um equipamento (Figura 42) para observação da velocidade de saturação; assim, acionou-se um cronômetro no momento em que cada amostra foi colocada sobre a pedra porosa, e ao passar do tempo, mediu-se o caminhamento da água (a partir de uma régua, instalada no próprio equipamento). Esse procedimento foi realizado até a saturação de cada amostra.

Após o término desta etapa, as amostras foram colocadas em tanque (Figura 43) para que ocorresse erosão em imersão de água. Os anéis foram colocados na vertical de forma que o solo pudesse cair em seus respectivos recipientes. Após $24 \mathrm{~h}$ os recipientes foram retirados e deixados na estufa, a aproximadamente $100^{\circ} \mathrm{C}$. Após secagem, foi possível obter a massa de solo retida para cada ponto de amostragem.

Figura 42 - Equipamento usado na saturação da amostra; detalhe da pedra porosa. 


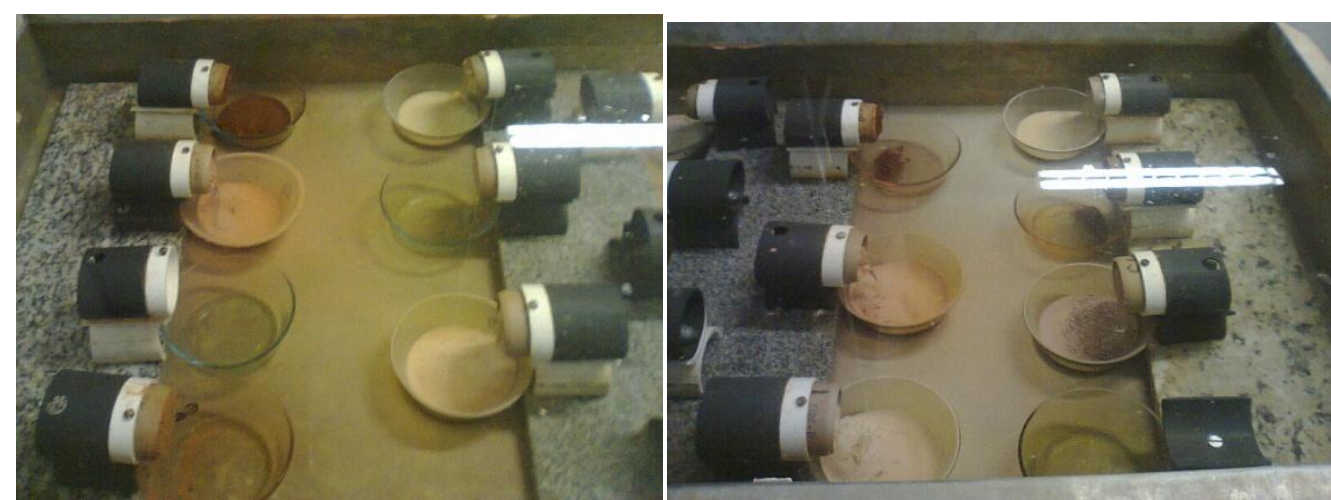

Figura 43 - Imersão em água das amostras para medida do solo desprendido.

Com estes dados foram realizados os cálculos de erodibilidade das amostras de solo segundo Pejon (1992). Para os limites de comparação dos resultados de erodibilidade foram utilizadas as Equação (14), de Nogami e Villibor (1979 apud PEJON, 1992) e Equação (15), de Pejon (1992).

$$
\begin{array}{ll}
P=52 . S & \text { Eq. (14) } \\
P=40 . S & \text { Eq. (15) }
\end{array}
$$

Segundo as quais, o índice de absorção de água é representado pela letra $S$ e a porcentagem de perda por imersão por $P$.

Destaca-se a dificuldade na retirada destas amostras em campo, e devido a isto, serão apresentados os resultados obtidos com as amostras LAT T3, SAP 1, SAP 2, SAP TX 3, SAP P 5, SAP P 7 e SAP P 8, apenas, por considerar que estas se encontravam em melhores condições, para tal ensaio (sem fissuras). 


\subsubsection{EnSaio Para ObTenÇÃo de Delta PH, DE CE E DE EH}

O ensaio de determinação do $\Delta \mathrm{pH}$ foi embasado na metodologia da EMBRAPA (1997), com algumas modificações. Foram utilizados (aproximadamente) $50 \mathrm{~g}$ de solo de cada ponto de amostragem, 125mL de água deionizada (para obtenção do $\mathrm{pH}$ em $\mathrm{H}_{2}$ ) e $125 \mathrm{~mL}$ de solução $1 \mathrm{M}$ de cloreto de potássio (para obtenção do $\mathrm{pH}$ em $\mathrm{KCl}$ ), mantendo-se sempre a proporção de 1:2,5. As amostras foram deixadas em agitação mecânica por meia hora (Figura 44A), sendo retiradas para descanso por mais uma hora (Figura 44B). Após este período, mediu-se o pH em pHmetro Digimed DM 21 (Figura 45A).

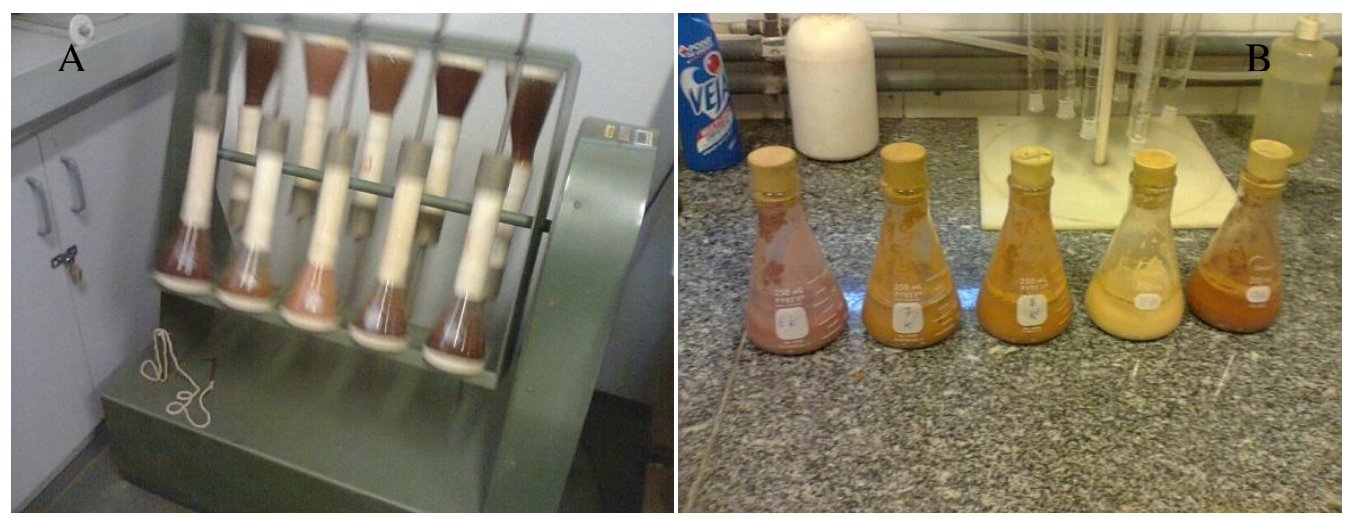

Figura 44 - A) Amostras sendo agitadas para determinação do $\Delta \mathrm{pH}$; B) amostras em descanso.

Através destes procedimentos também foi possível realizar medições de Condutividade Elétrica (CE) e de potencial de oxi-redução (Eh); para tanto, foram empregados Condutivímetro Analyser 650 e pHmetro Micronal B374 com eletrodo de Eh (estas medidas foram realizadas só na solução com $\mathrm{H}_{2} 0$ ). As Figuras 45A, 45B e 45C exibem os equipamentos utilizados para obtenção destes parâmetros físico-químicos. O ensaio foi realizado com as amostras LAT 1, LAT T2, LAT T3, SAP 1, SAP 2, SAP TX 3, SAP TX 4, SAP P 5, SAP P 6, SAP P 7 e SAP P 8 , e para se obter o valor de $\Delta \mathrm{pH}$ foi utilizada a Equação (16).

$$
\Delta p H=\mathrm{pH} \mathrm{KCl}-\mathrm{pH} \mathrm{H}_{2} \mathrm{O} \quad \boldsymbol{E q} \cdot(\mathbf{1 6})
$$


Este ensaio foi realizado no Laboratório de Geotecnia do Departamento de Geotecnia da EESC-USP.
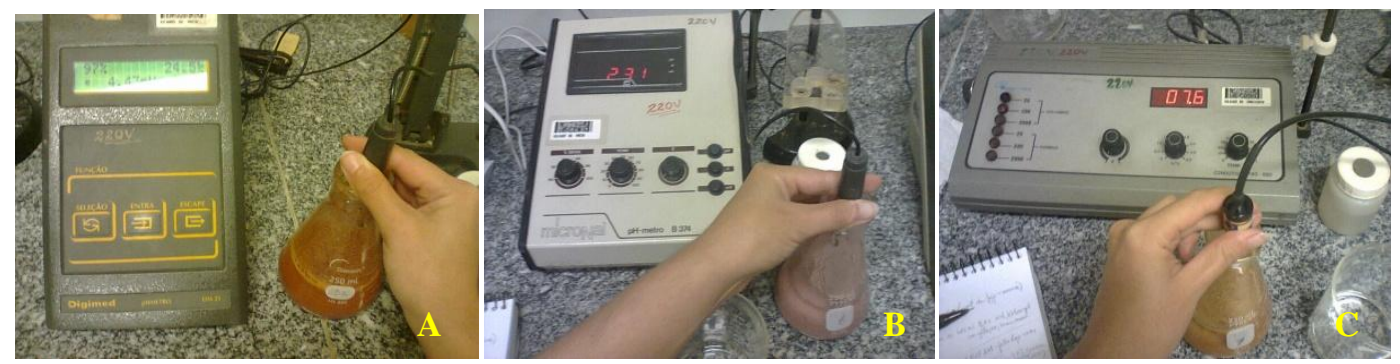

Figura 45 - A) pHmetro Digimed empregado na determinação do pH; B) phmetro Micronal empregado na determinação do Eh; C) Condutivímetro Analyser usado na determinação da CE.

\subsubsection{ENSAIO DE OXIDAÇÃO DA MATÉRIA ORGÂNICA}

Este ensaio foi realizado de acordo com a metodologia utilizada por Eusterhues, Rumpel e Kögel-Knabner (2005). Foram utilizados $2 \mathrm{~g}$ de solo para cada ponto de amostragem, aos quais se adicionaram de 20 a $30 \mathrm{~mL}$ de peróxido de hidrogênio $\left(\mathrm{H}_{2} \mathrm{O}_{2}\right)$ para oxidação da matéria orgânica. Essas soluções foram colocadas em uma chapa com temperatura de $60^{\circ} \mathrm{C}$ (Figura 46). O peróxido de hidrogênio foi adicionado, conforme aumento do borbulhamento durante o aquecimento (ataque da matéria orgânica). Conforme ocorreu diminuição do ataque da matéria orgânica (diminuição do borbulhamento), foi adicionada água destilada para lavagem da amostra. 


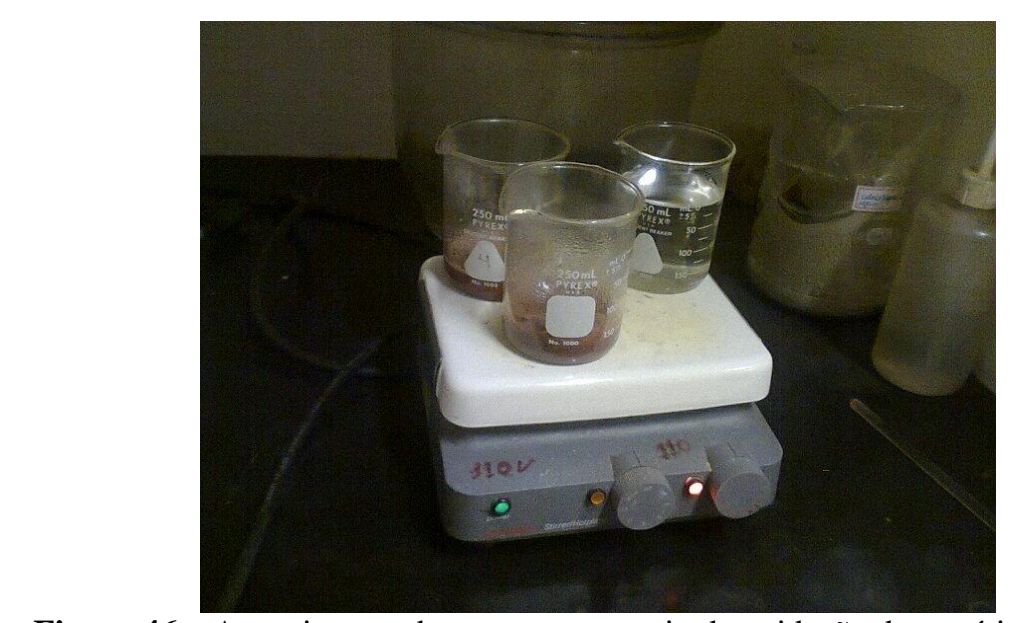

Figura 46 - Aquecimento das amostras, ensaio de oxidação de matéria orgânica.

Após encerramento dos processos de oxidação, a amostra permaneceu na chapa aquecedora até evaporação total da água, sendo então retirada e colocada em estufa com temperatura de $60^{\circ} \mathrm{C}$. As amostras permaneceram na estufa até secagem total. A proporção de matéria orgânica no solo foi obtida através da Equação (17):

$$
\% \text { M.O. }=\left[1-\left(\frac{M_{S}}{M_{t}}\right)\right] \cdot 100
$$

Em que a porcentagem de matéria orgânica no solo, \% $M$. $O$., é função da quantidade de solo seco restante após a oxidação com peróxido de hidrogênio, $M_{s}$, em relação à quantidade total de solo utilizada no ensaio, $M_{t}$. Estes procedimentos foram realizados no Laboratório de Geoquímica do Departamento de Geotecnia da EESC-USP. 
5.3.5 Ensaio de ClassificaÇÃo de solos - Miniatura, Compactada, Tropical (MCT) E ANÁLISE GRANULOMÉTRICA CONJUNTA

O ensaio de classificação de solos tropicais foi realizado em conjunto com Raul Cassaro, segundo procedimentos contidos em Nogami e Villibor (1995), e segundo as normas do Departamento Nacional de Estradas e Rodagem (DNER): ME 228/94 - Solos Compactação em Equipamento Miniatura, ME 256/94 - Solos Compactados em Equipamento Miniatura - Perda por Imersão, ME 258/94 - Solos Compactados em Equipamento Miniatura - Mini-MCV. As amostras utilizadas para este ensaio foram a LAT 1 e a SAP P 7. A Figura 47 apresenta o equipamento utilizado para compactação do corpo de prova (Moisture, Condition, Value - Umidade, Condição, Valor - Mini MCV) e o tanque para realização da perda de massa por imersão, respectivamente.

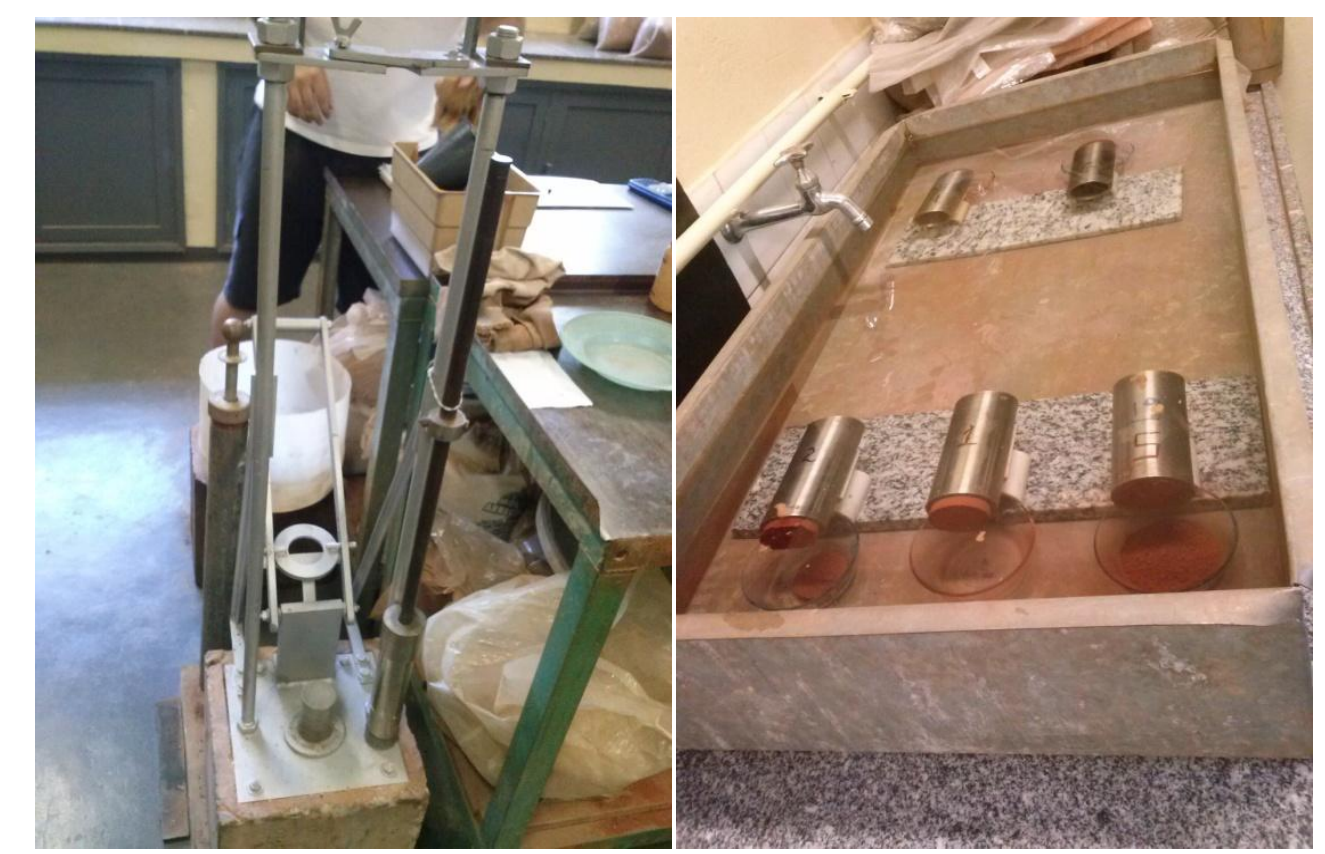

Figura 47 - Compactador de Mini MCV para o ensaio MCT, à esquerda, e tanque para ensaio de perda de massa por imersão, à direita.

Também foi realizada a análise granulométrica conjunta destas duas amostras, segundo a norma NBR 6508: Grãos de solo que passam na peneira de 4,8 mm Determinação da massa específica (ABNT, 1984a) e NBR 7181: Solo - Análise granulométrica (ABNT, 1984b). Este ensaio foi realizado no Laboratório de Mecânica dos 
Solos do Departamento de Geotecnia, da Escola de Engenharia de São Carlos (EESC), da Universidade de São Paulo (USP).

\subsubsection{Microscopia Eletrônica de VARredura (MEV) E EsPectroscopia de ENERGIA DISPERSIVA (EDS)}

Para a análise em MEV, as amostras foram preparadas em stubs e recobertas com 6 nm de ouro seguido de evaporação de carbono em um metalizador Coating System BAL-TEC MED 020 (BAL-TEC, Liechtenstein) e mantidas em dessecador até o momento de análise. As condições de metalização foram:

- $\quad$ pressão na câmara $=2,00 \times 10^{-2} \mathrm{mbar}$;

- $\quad$ corrente $=60 \mathrm{~mA}$;

- taxa de deposição $0,60 \mathrm{~nm} / \mathrm{s}$.

As fotomicrografias foram obtidas na Central de Análises Químicas Instrumentais do Instituto de Química de São Carlos (CAQI/IQSC/USP) em um equipamento ZEISS LEO 440 (Cambridge, England) com detector OXFORD (model 7060), operando com feixe de elétrons de $15 \mathrm{kV}$.

A análise de Energia Dispersiva (EDS) foi realizada em um equipamento EDX LINK ANALYTICAL, (Isis System Series 200), com detetor de SiLi Pentafet, janela ultrafina ATW II (Atmosphere Thin Window), de resolução de $133 \mathrm{eV}$ à $5,9 \mathrm{keV}$ e área de $10 \mathrm{~mm}^{2}$ quadrado, acoplado a um Microscópio Eletrônico ZEISS LEO 440 (Cambridge, England). Foi utilizado o padrão de Co para calibração, feixe de elétrons de $20 \mathrm{kV}$, distância focal de $25 \mathrm{~mm}$, dead time de $30 \%$, corrente de 2,82A e I probe de 2,5nA. A área da amostra analisada foi de $320 \times 320 \mu \mathrm{m}$.

As análises de MEV/EDS foram realizadas com as amostras LAT T3, SAP 1, SAP 2, SAP TX 3, SAP P 5, SAP P 6 e SAP P 8. 


\subsection{Tratamento dos Dados Pluviométricos}

Os dados pluviométricos foram adquiridos a partir do banco de dados disponibilizado gratuitamente pela Agência Nacional de Águas (ANA) no Localizador Padrão de Recursos (URL - Uniform Resource Locator) <http://www2.ana.gov.br/Paginas/default.aspx> .

Nesta URL, foi acessada a aba Portais e, em seguida, o URL da Hidroweb Serviços de Informações Hidrológicas (http://hidroweb.ana.gov.br/), onde foram obtidas as séries históricas (arquivo Access) utilizadas nesta pesquisa.

Estas séries históricas de precipitações referem-se aos municípios de Bom Sucesso, Lavras e São João Del Rei, localizados nas proximidades de Nazareno. Todos os municípios estão contidos na Bacia Hidrográfica do Rio Paraná (6) e na Sub-bacia do Rio Grande (61). Foram encontrados sete registros pertencentes a Bom Sucesso, dez de Lavras e onze registros de São João Del Rei, sendo escolhidas dentre estas as estações que continham maiores informações referentes ao período de 1973 a 2013. A Tabela 12 exibe os dados das estações pluviométricas escolhidas.

Tabela 12- Dados das estações pluviométricas.

\begin{tabular}{|c|c|c|c|c|c|c|c|}
\hline Código & Nome & Estado & Município & Responsável & Operadora & $\begin{array}{c}\text { Coordenadas } \\
\text { Geográficas } \\
\end{array}$ & $\begin{array}{c}\text { Altitude } \\
\text { (m) }\end{array}$ \\
\hline 2144000 & $\begin{array}{c}\text { BOM } \\
\text { SUCESSO }\end{array}$ & $\begin{array}{l}\text { Minas } \\
\text { Gerais }\end{array}$ & Bom Sucesso & ANA & IGAM & $\begin{array}{c}-21: 2: 2 \\
-44: 46: 19\end{array}$ & 836 \\
\hline 2145007 & $\begin{array}{c}\text { USINA } \\
\text { COURO DO } \\
\text { CERVO }\end{array}$ & $\begin{array}{l}\text { Minas } \\
\text { Gerais }\end{array}$ & Lavras & ANA & CPRM & $\begin{array}{l}-21: 20: 37 \\
-45: 10: 13\end{array}$ & 813 \\
\hline 2144020 & $\begin{array}{c}\text { USINA SÃO } \\
\text { JOÃO DEL } \\
\text { REI }\end{array}$ & $\begin{array}{l}\text { Minas } \\
\text { Gerais }\end{array}$ & $\begin{array}{c}\text { São João Del } \\
\text { Rei }\end{array}$ & ANA & IGAM & $\begin{array}{c}-21: 3: 20 \\
-44: 12: 32\end{array}$ & 842 \\
\hline 2144024 & $\begin{array}{c}\text { VILA RIO } \\
\text { DAS } \\
\text { MORTES }\end{array}$ & $\begin{array}{l}\text { Minas } \\
\text { Gerais }\end{array}$ & $\begin{array}{c}\text { São João Del } \\
\text { Rei }\end{array}$ & ANA & IGAM & $\begin{array}{l}-21: 11: 22 \\
-44: 19: 44\end{array}$ & 870 \\
\hline
\end{tabular}

ANA: Agência Nacional de Águas; IGAM: Instituto Mineiro de Gestão das Águas; CPRM: Serviço Geológico do Brasil.

Os dados de 2013 estavam incompletos (de janeiro a dezembro); desta forma, este ano não foi incluso nas considerações e procedimentos realizados na presente pesquisa. 
Os dados em Access foram exportados para o Excel, onde foram calculadas as médias e as máximas mensais das precipitações de cada estação, em milímetros. Para facilitar a visualização dos dados, denominou-se a estação de Bom Sucesso de $y$, a estação da Usina Couro do Cervo de $x_{1}$, a estação da Usina São João Del Rei de $x_{2}$, e a estação Vila Rio das Mortes de $x_{3}$, já que houve constatação de que a de Bom Sucesso continha o maior número de dados pluviométricos dentre as outras e se encontrava próxima do município de Nazareno.

Diante disso, para o preenchimento das falhas encontradas na estação de Bom Sucesso, considerou-se que os anos entre 1973 e 2012 que apresentavam quatro ou mais meses com falhas não seriam utilizados. Os anos de 1989, 2006, 2007, 2008 e 2010, portanto, foram descartados das análises. Em relação aos dados de Bom Sucesso em si, considerou-se que, caso estivesse faltando pelo menos um valor de medida de precipitação no mês, este mês seria considerado como falho.

Em seguida, utilizou-se o método da regressão linear simples, apresentado por Lanna (2001), no ambiente de Excel, sendo y a estação com os dados a serem preenchidos, e $x$ as estações com dados para comparação, $i=1,2,3, \ldots, n$ e $n$ o total de estações utilizadas. Para tanto, os passos empregados foram:

- Determinação do desvio padrão (raiz quadrada da variância), $s_{x}$ ou $s_{y}$, de cada estação, para verificar como seria a flutuação dos valores em torno da média, baseando-se na Equação (18):

$$
s_{x}=\sqrt{\sum_{i=1}^{n} \frac{\left(x_{i}-\bar{x}\right)^{2}}{n}}
$$

- A Co-variância amostral, $s_{x y}$, que relaciona duas variáveis para se observar qual é a tendência entre elas, Equação (19):

$$
s_{x y}=\frac{1}{n} \sum_{i=1}^{n} x_{i} \cdot y_{i}-\bar{x} \cdot \bar{y}
$$


- O Coeficiente de correlação, $r_{x y}$, que, caso mais se aproxime de 1 , representa o melhor ajuste à tendência de linearidade entre variáveis (Equação 20):

$$
r_{x y}=\frac{s_{x y}}{s_{x} \cdot s_{y}}
$$

- Equação da regressão linear simples, a qual descreve a relação entre duas variáveis, neste caso, $y$ representando a estação de Bom Sucesso, e $x$, as outras estações, que segue a tendência de $y=f(x)$ retilinear, e que, através do método dos mínimos quadrados, segue as considerações realizadas por Lanna (2001), Equação (21):

$$
\frac{(y-\bar{y})}{s_{y}}=r_{x y} \cdot \frac{(x-\bar{x})}{s_{x}}
$$

E que, rearranjando, torna-se:

$$
y=\bar{y}+s_{y} \cdot\left(r_{x y} \cdot \frac{(x-\bar{x})}{s_{x}}\right)
$$

Após o preenchimento das falhas, foi realizado um gráfico contendo os dados completos de chuvas médias e máximas mensais, ano a ano considerado, para se obter a estimativa de padrão de comportamento das chuvas para a área.

Diante da observação de que esse comportamento das chuvas poderia não ser representativo devido à excessiva necessidade de preenchimento de falhas e descarte dos anos com dados incompletos, optou-se por utilizar esses dados somente em avaliação qualitativa, e realizar o estudo das condições hidrológicas através de análise indireta com o software ABC 6 .

O software ABC 6, do Sistema de Suporte a Decisões para Análise de Ondas de Cheia em Bacias Complexas (SSD ABC), do Laboratório de Sistemas de Suporte a Decisões (LabSid - Departamento de Engenharia Hidráulica e Ambiental - Escola Politécnica, USP), foi utilizado nesta pesquisa com a finalidade de se obter o hidrograma das chuvas como suporte ao projeto de drenagem. O download deste software pode ser realizado através do 
URL <http://www.labsid.eng.br/>, na aba Produtos, sendo encontrado, também, o Manual e as explicações pertinentes à utilização do $A B C 6$.

Dos métodos de análise de hidrograma contidos no $A B C$ 6, o método da Soil Conservation Service (SCS) foi escolhido, por possibilitar a entrada de dados de solo e uso e ocupação, embutidos nos valores do Número da Curva (Curve Number - CN) e nos cálculos de porcentagens de áreas impermeáveis, para se obter os hidrogramas. Além de utilizar a base de dados com as equações de intensidade-duração-frequência (equações $I D F$ ) para regiões do Brasil, neste método, a análise da infiltração se encontra correlacionada ao $C N$.

Inicialmente, através das observações de campo e do mapa de direção de fluxo, observou-se qual seria a área de influência direta da drenagem superficial da voçoroca do Córrego do Cravo em relação a toda a bacia. Dessa forma, uma área menor, considerada como a bacia de contribuição da voçoroca, foi delineada no $A r c G I S^{\circledR}$ e utilizada para o $A B C$ 6, para melhor detalhamento das características predominantes na avaliação (Anexo 03). Também foram delineadas e obtidas as áreas de uso e ocupação para o cálculo do $C N$ no $\operatorname{ArcGIS}{ }^{\circledR}$; no $A B C$ 6, a média deste parâmetro é realizada com três valores de $C N$, sendo, portanto, considerados os três tipos de uso predominantes como a "cultura em fileiras: curvas de nível, condições boas" para o cafezal, "estrada de terra dura" e utilizou-se o $C N$ de "florestas muito esparsas" para representar a vegetação presente na voçoroca, que se caracteriza por apresentar pastagens (em menor proporção) em conjunto com as plantas de revegetação (Projeto Maria de Barro) e sucessão natural (Figura 48). 


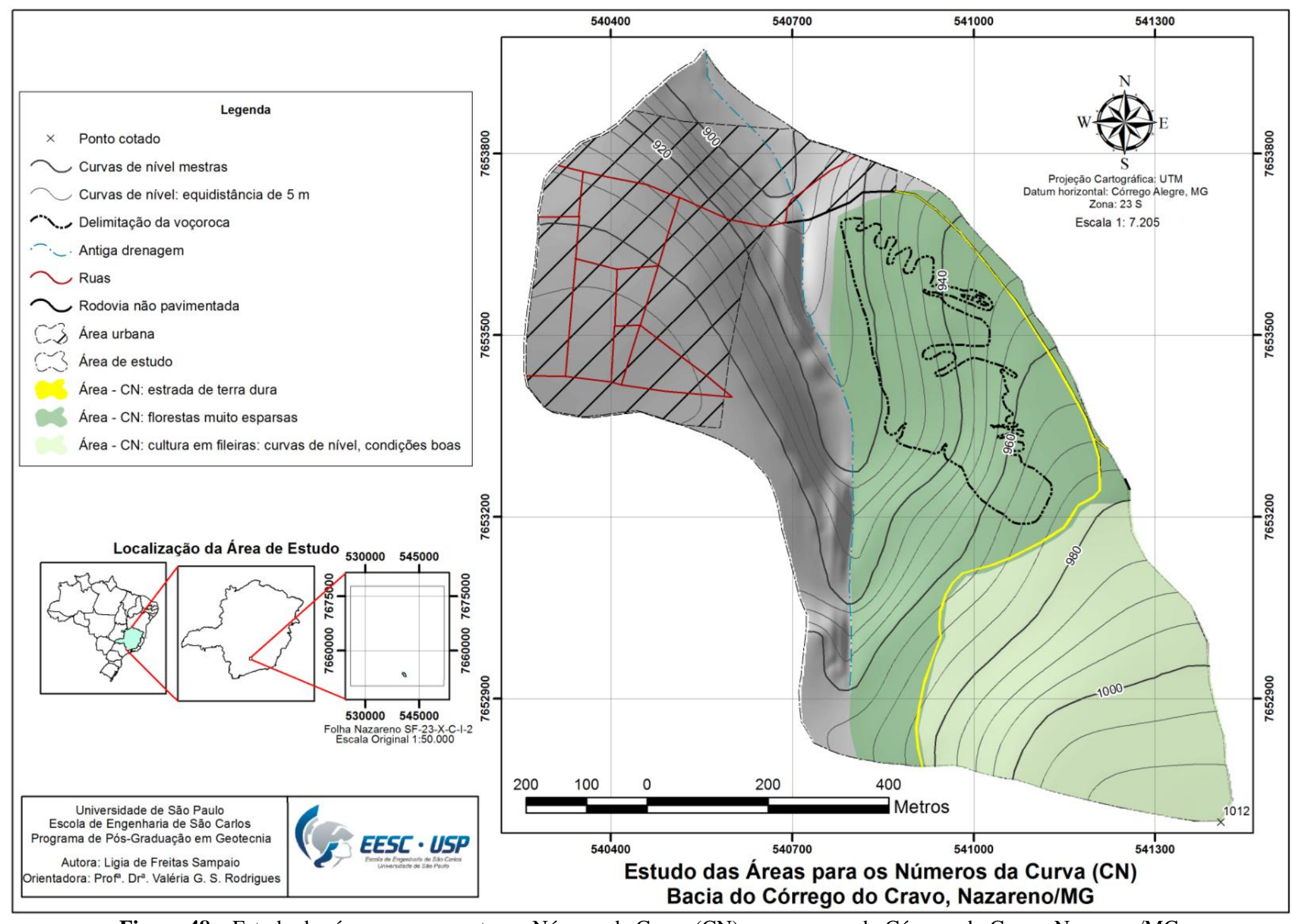

Figura 48 - Estudo das áreas para encontrar o Número da Curva (CN) na voçoroca do Córrego do Cravo, Nazareno/MG. 
Em seguida, o desenho da bacia foi realizado na interface do programa, como mostra a Figura 49. No $A B C$ 6, os nós representam o início e o final da bacia; para este caso, o nó 1 representa a cabeceira da voçoroca, e o nó 2 , representa a base à jusante. $\mathrm{O}$ arco representa $\mathrm{o}$ trecho da bacia.

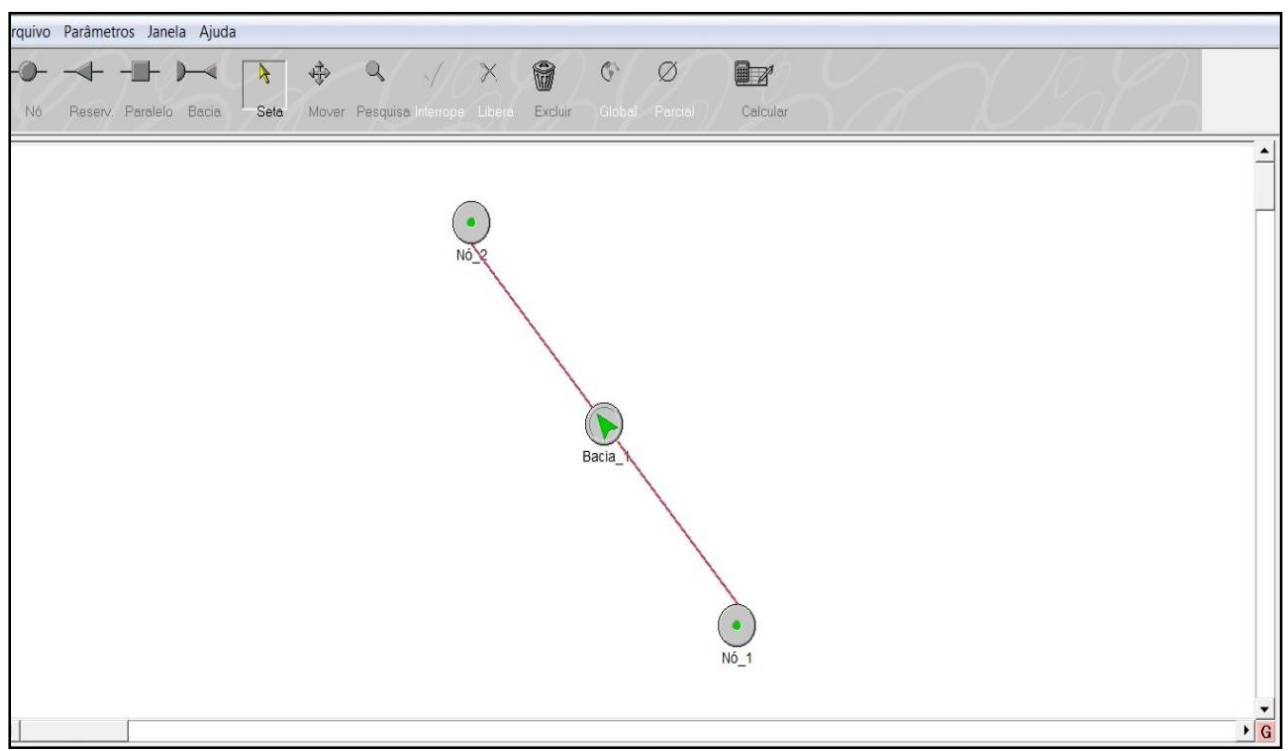

Figura 49 - Esquema da bacia do Córrego do Cravo, na interface do $A B C 6$.

Como Parâmetros de entrada, foram considerados o intervalo de 30 minutos de discretização para os cálculos, e o período de retorno de 10 anos, para se obter o cenário aproximado para as obras de drenagem. Como mencionado, nos Modelos dos Parâmetros do programa, foram considerados o SCS para chuva excedente e o Triangular do SCS como hidrograma padrão.

Os dados utilizados como entrada para os cálculos da bacia no programa são apresentados na Tabela 13, sendo que as considerações feitas para o cálculo do tempo de concentração no programa são apresentadas na Figura 50. 
Tabela 13 - Dados de entrada para o cálculo da bacia realizado no programa $A B C 6$.

Características Físicas

Observações

Bacia

\begin{tabular}{c|c|c}
\hline Área $\left(\mathbf{k m}^{\mathbf{2}}\right)$ & 0,443 & Encontrada utilizando-se ArcGIS \\
\hline $\begin{array}{c}\text { Área impermeável } \\
\mathbf{( \% )}\end{array}$ & - & $\begin{array}{c}\text { Considerada não existente: área das } \\
\text { residências muito inferior às outras } \\
\text { áreas }\end{array}$ \\
\hline $\begin{array}{c}\text { Área diretamente } \\
\text { conectada }(\%)\end{array}$ & - & Considerada não existente \\
\hline
\end{tabular}

Tempo de Concentração

\begin{tabular}{c|c|c}
\hline $\begin{array}{c}\text { Tempo de } \\
\text { concentração (h) }\end{array}$ & 0,75 & \multirow{2}{*}{ Considerações - Figura 50 } \\
\cline { 1 - 2 } Calculado por & SCS & \\
\hline Equação empírica & SCS & \\
\hline
\end{tabular}

Dados do Canal

\begin{tabular}{c|c|c}
\hline Comprimento (m) & 1177,1 & Encontrado utilizando-se ArcGIS \\
\hline Velocidade $\left(\mathbf{m . s}^{\mathbf{- 1}}\right)$ & 0,73 & Dada pelo $A B C 6$ \\
\hline $\begin{array}{c}\text { Tempo de trânsito } \\
\text { da onda de cheia } \\
(\mathbf{h})\end{array}$ & 0,45 & Dado pelo $A B C 6$ \\
\hline $\begin{array}{c}\text { Coeficiente de } \\
\text { amortecimento } \\
(\mathbf{0}<\mathbf{x}<\mathbf{0 , 5})\end{array}$ & 0,25000 & Dado pelo $A B C 6$ \\
\hline
\end{tabular}




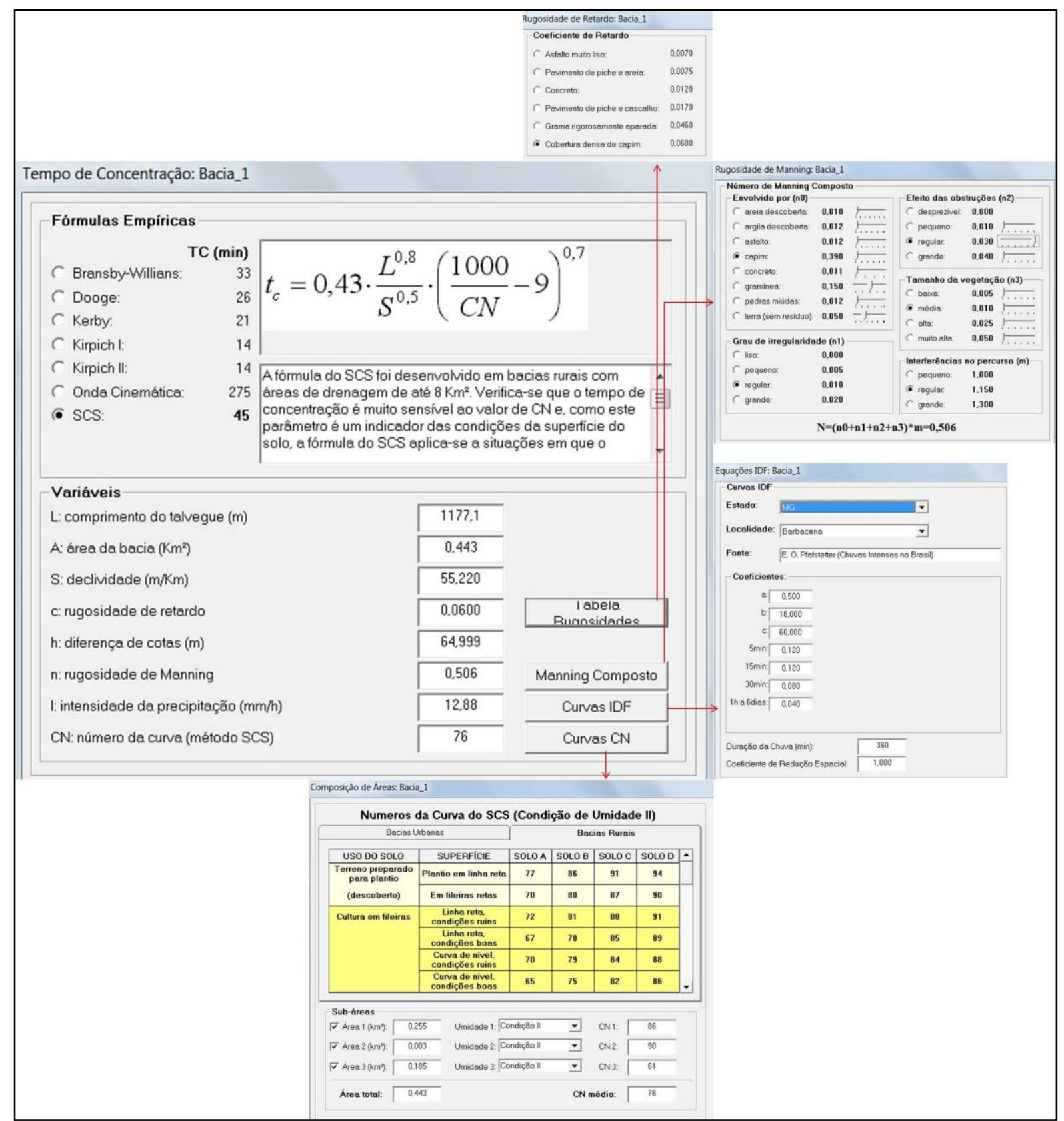

Figura 50 - Considerações feitas para o cálculo do tempo de concentração utilizando a equação do método SCS.

O ietograma das precipitações da área gerado a partir das curvas $I D F$ consideradas no $A B C 6$ é apresentado na Figura 51. Para a infiltração, foi considerado o $C N$ médio encontrado conforme a Figura 52, no método SCS. 


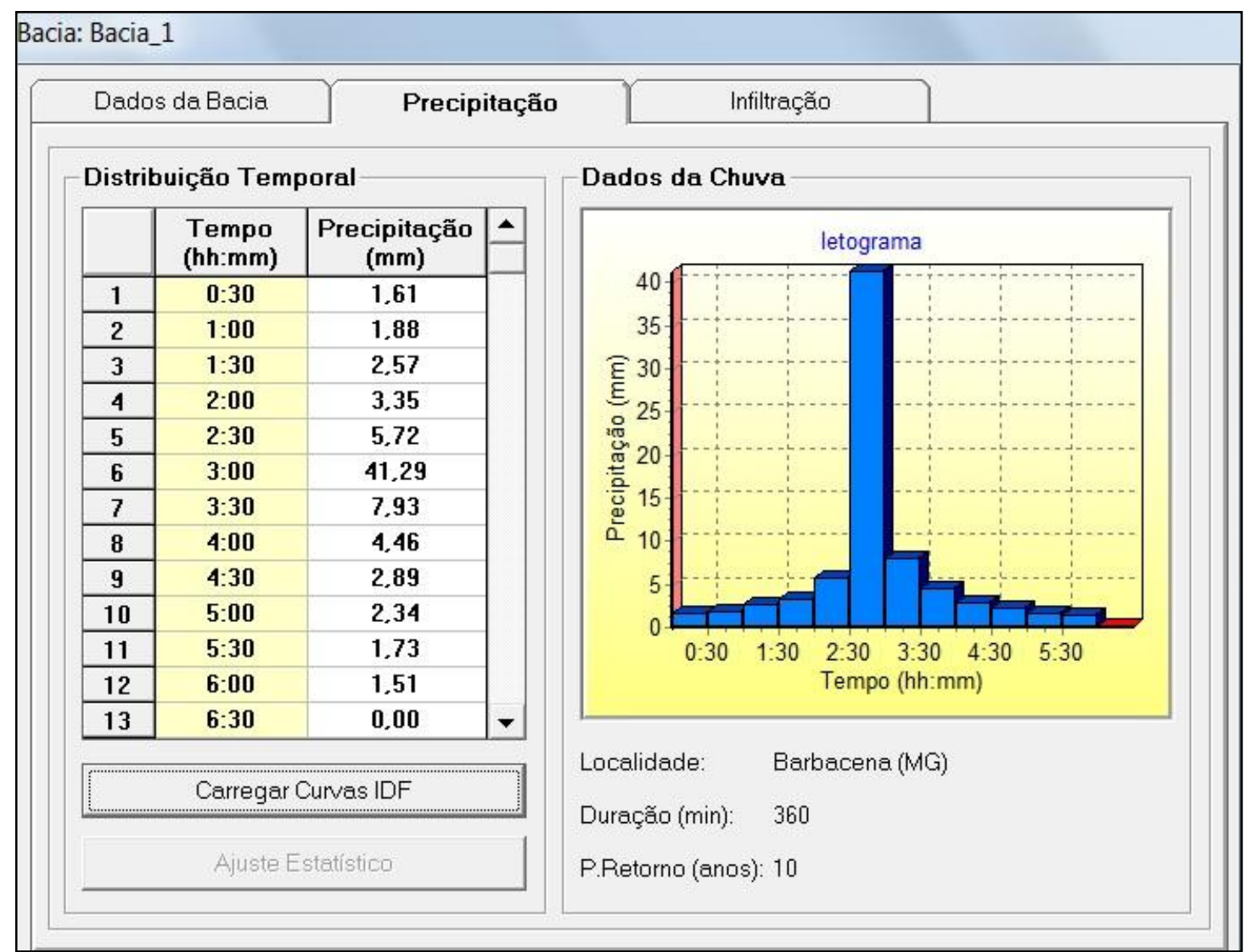

Figura 51 - Ietograma de precipitações utilizando as curvas $I D F$ de Barbacena/MG - $A B C 6$.

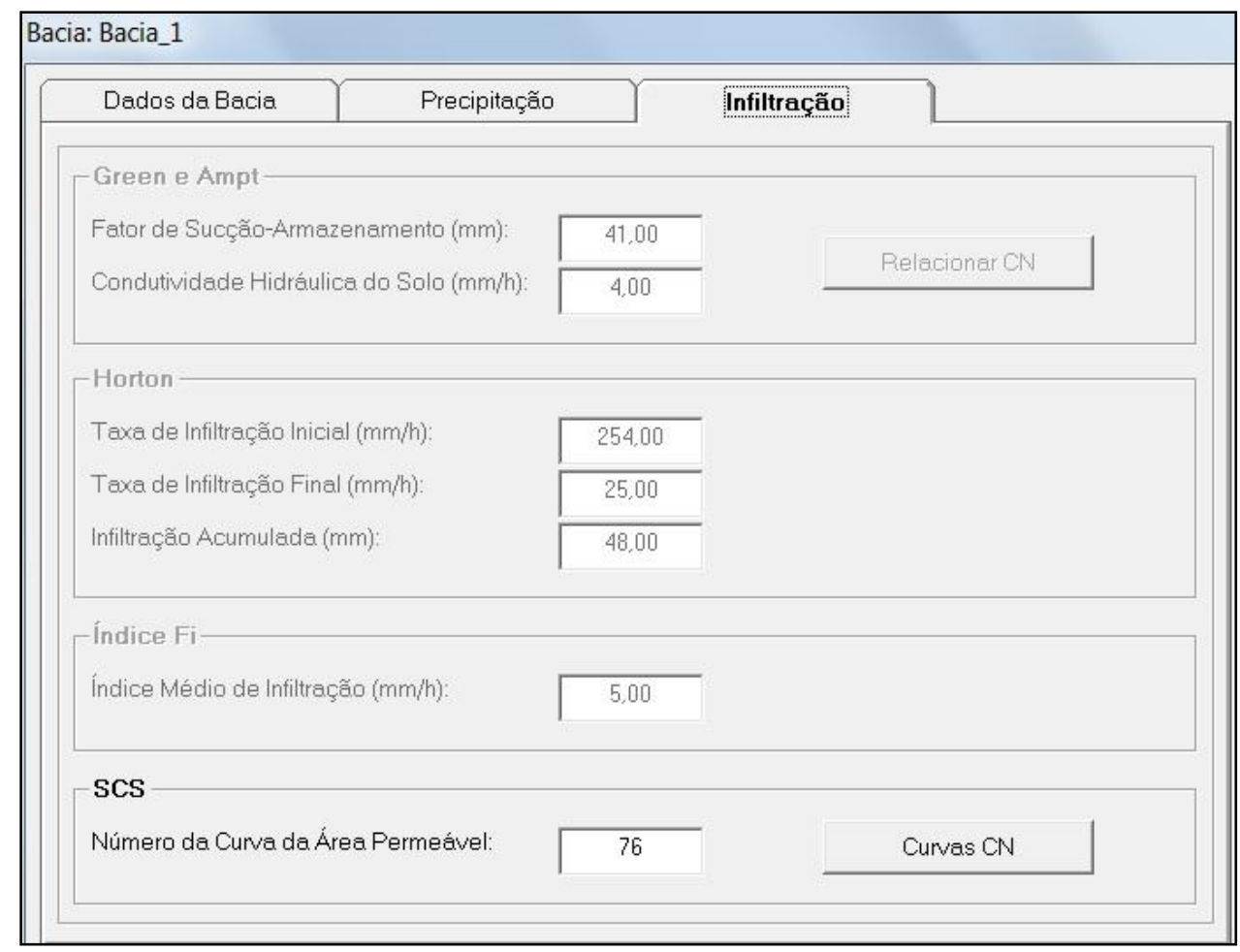

Figura 52 - Curva $C N$ (infiltração no método $S C S)-A B C 6$. 


\subsection{Estudo Preliminar do Disciplinamento da Drenagem - Voçoroca do Córrego do Cravo}

Para a realização das propostas para o disciplinamento das drenagens na voçoroca do Córrego do Cravo, foi necessário avaliar, além das condições físicas do ambiente, as características de vazão de projeto em combinação com as técnicas utilizadas para estas obras. Por se tratar de uma bacia hidrográfica pequena, na qual poderão ser aplicadas obras de drenagem de médio e pequeno porte, foi possível optar por algumas metodologias de fácil acesso e que, ainda assim, produzem uma boa estimativa dos comportamentos esperados para esta problemática. Estas metodologias e as técnicas utilizadas serão apresentadas nos tópicos seguintes.

\subsubsection{ESCOAMENTO SUPERFICIAL}

Para estudo das características dos canais de drenagem superficial, utilizou-se o software Canal desenvolvido pelo Grupo de Pesquisa em Recursos Hídricos (GPRH), da Universidade Federal de Viçosa (UFV). Pode-se realizar o download deste software através do URL <http://www.gprh.ufv.br/>, na aba Softwares.

O ambiente de trabalho do software Canal pode ser observado na Figura 53. Podem ser utilizadas variações das formas de canais, sendo que, para cada tipo, é possível escolher um parâmetro como incógnita, a qual será respondida pelos cálculos realizados pelo programa. Este software foi utilizado com a finalidade de se estudar as formas e variáveis dos canais que apresentam maior influência na velocidade e regime do escoamento superficial, para, a partir dessa avaliação, realizar uma proposta adequada para a problemática encontrada na área de estudo. 


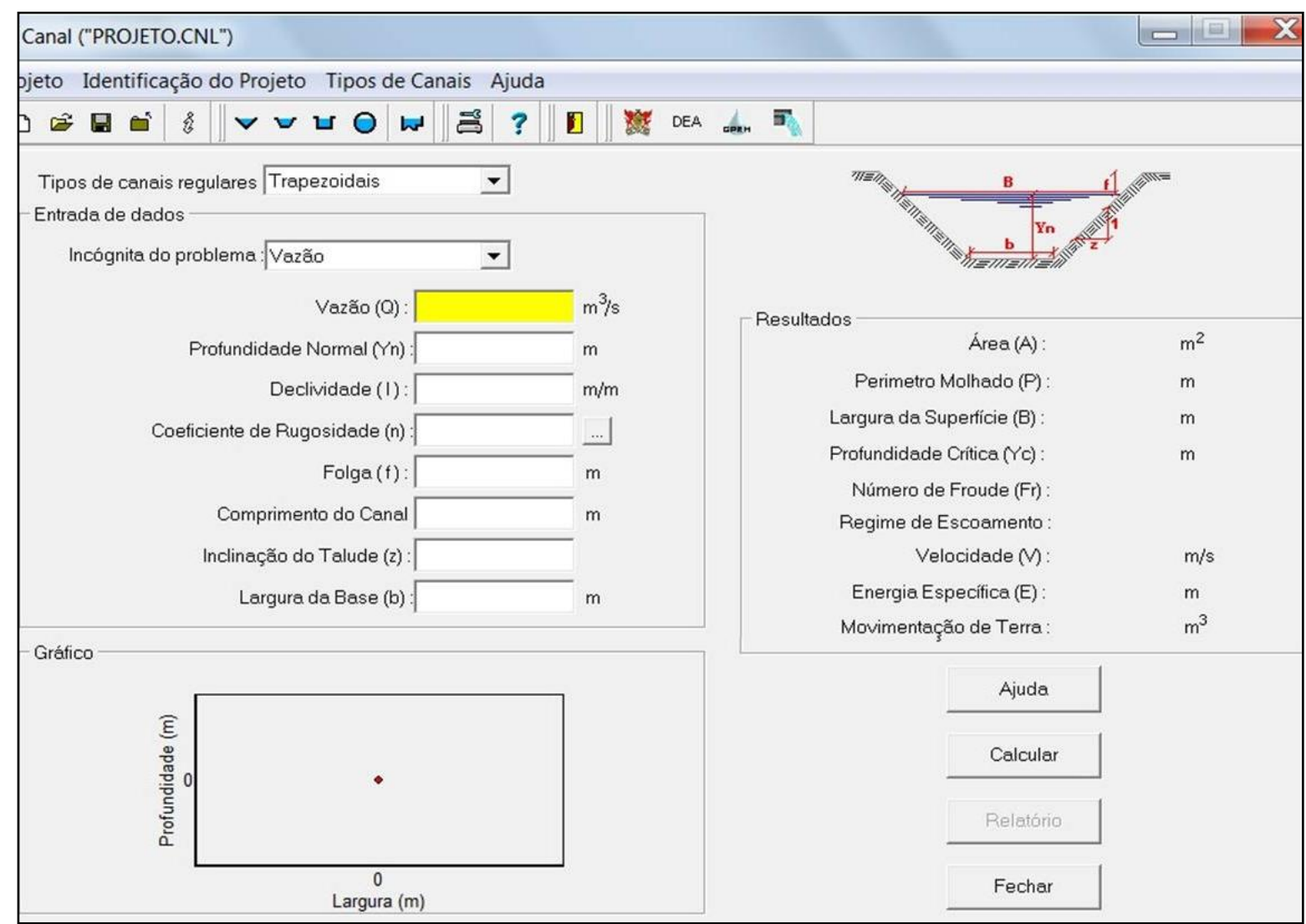

Figura 53 - Ambiente para trabalho utilizando o software Canal (GPRH - Universidade Federal de Viçosa).

Os parâmetros de profundidade normal $(Y n)$, folga $(f)$, comprimento do canal, inclinação do talude e largura da base ( $z$ e $b$, respectivamente) para canais trapezoidais, e diâmetro $(D)$ para canais circulares, foram estabelecidos para adequarem-se à viabilidade de construção na área e de forma a se obter segurança com os cálculos. As propostas de drenagem para a bacia de contribuição da voçoroca do Córrego do Cravo foram apresentadas conjuntamente em um croqui.

Como forma de reduzir o escoamento direto na voçoroca, advindo da estrada de terra que faz limite em sua lateral, foi realizada uma proposta adicional de condução e infiltração da água também para esta situação, baseando-se nas técnicas compensatórias lineares propostas por Baptista, Nascimento e Barraud (2011). 


\subsubsection{DRENAGEM DO ESCOAMENTO SUbTERRÂNEO}

A partir das observações em campo em relação ao afloramento de água subterrânea no interior da voçoroca e seu comportamento de causar erosão em piping (tubular), e do estudo das características geotécnicas dos tipos dos solos, foi elaborada uma proposta para reduzir a ação do escoamento subsuperficial no que concerne à desestabilização e desagregação do solo, com a finalidade adicional de manutenção de um aporte de água e configuração do terreno adequados para o estabelecimento da vegetação em seu interior. Esta proposta teve como base as técnicas de bioengenharia propostas por Durlo e Sutili (2005) e as considerações acerca do desenvolvimento dos processos fluviais, realizadas por Knighton (1998).

\section{RESUlTAdOS E DisCUSSÃO}

\subsection{Análise Integrada: ArcGIS ${ }^{\circledR}$ e Dados de Campo}

A compreensão de alguns aspectos da área de estudo pôde ser efetivamente realizada através das análises dos dados no $A r c G I S^{\circledR}$. Sua utilização auxiliou na visualização de tais aspectos, combinação de informações e para as propostas de drenagem realizadas para a voçoroca do Córrego do Cravo; este tipo de ação não substitui visitações em campo e troca de conhecimentos interpessoais, mas, ao reunir todos estes conhecimentos, pode-se obter uma aproximação inicial que serviram para auxiliar na interpretação e uso posterior dos dados.

Primeiramente, como já descrito no Capítulo 5.2, foram realizadas digitalizações das curvas de nível, curso d'água, área urbana e estradas, sendo obtidas, posteriormente, curvas de nível de equidistância de 5 em 5 metros. Após este procedimento, foi obtido o Modelo Digital 
de Elevação (MDE) e o modelo sombreado do terreno da bacia do Córrego do Cravo, sendo possível, portanto, gerar o mapa de classes hipsométricas.

Também foram gerados mapas de classes de declividade, com classificação segundo EMBRAPA (2006c), e de direção de fluxo, para se compreender por onde o escoamento superficial seria preferencialmente direcionado. Estes mapas, juntamente com o MDE, são apresentados nas Figursa 54, 55 e 56. 


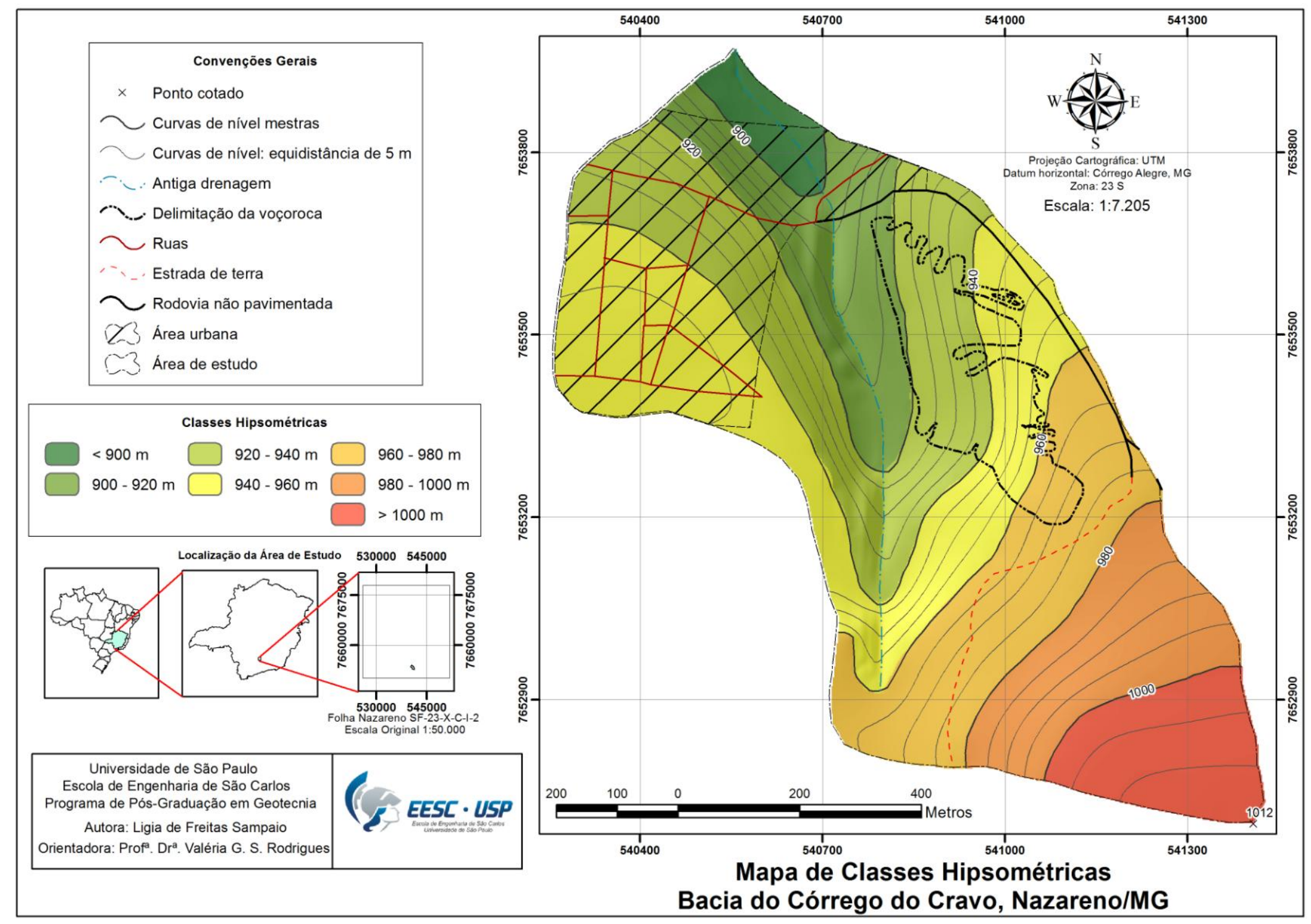

Figura 54 - Mapa de classes hipsométricas da bacia do Córrego do Cravo, Nazareno/MG. 


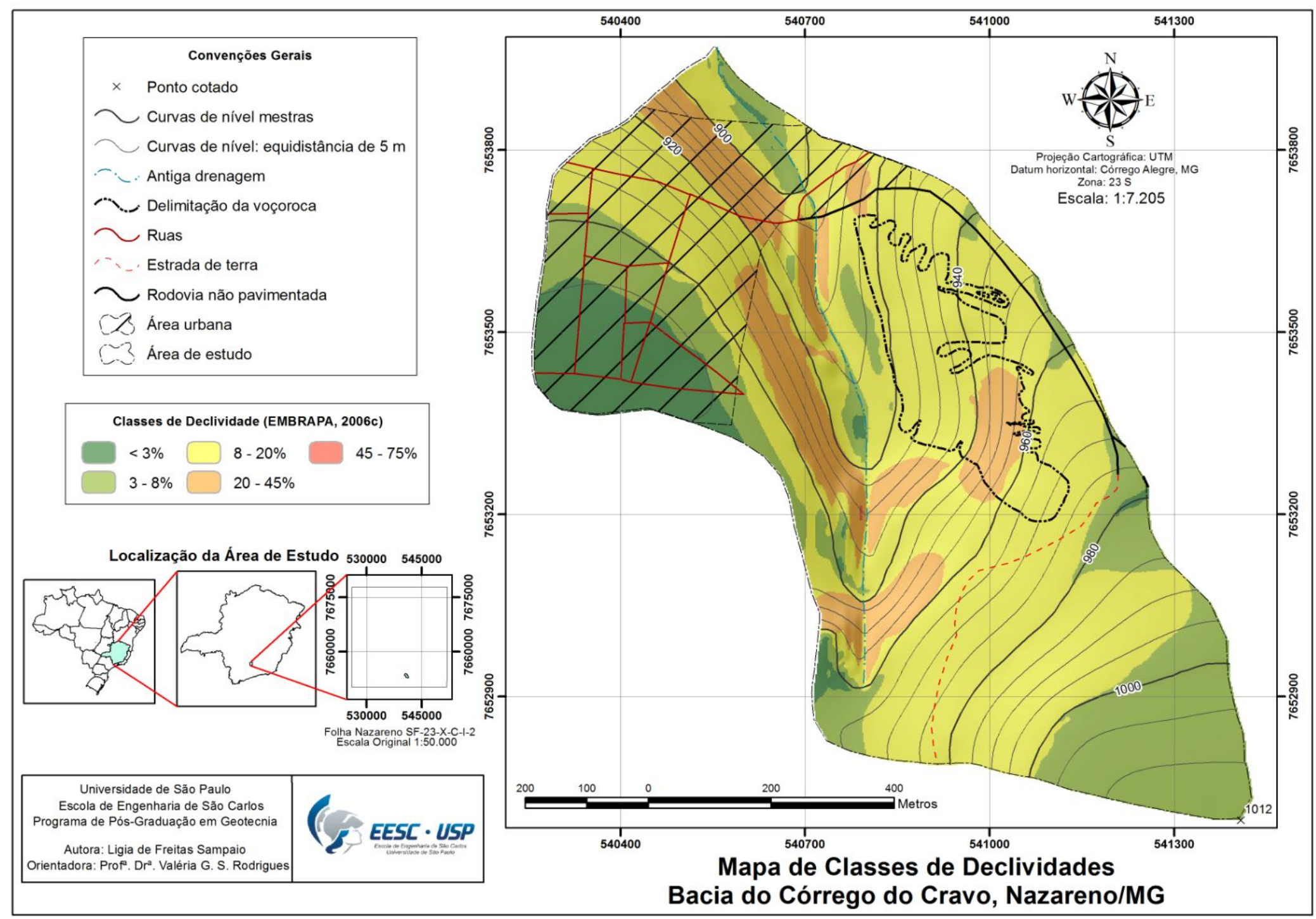

Figura 55 - Mapa de classes de declividade da bacia do Córrego do Cravo, Nazareno/MG. 


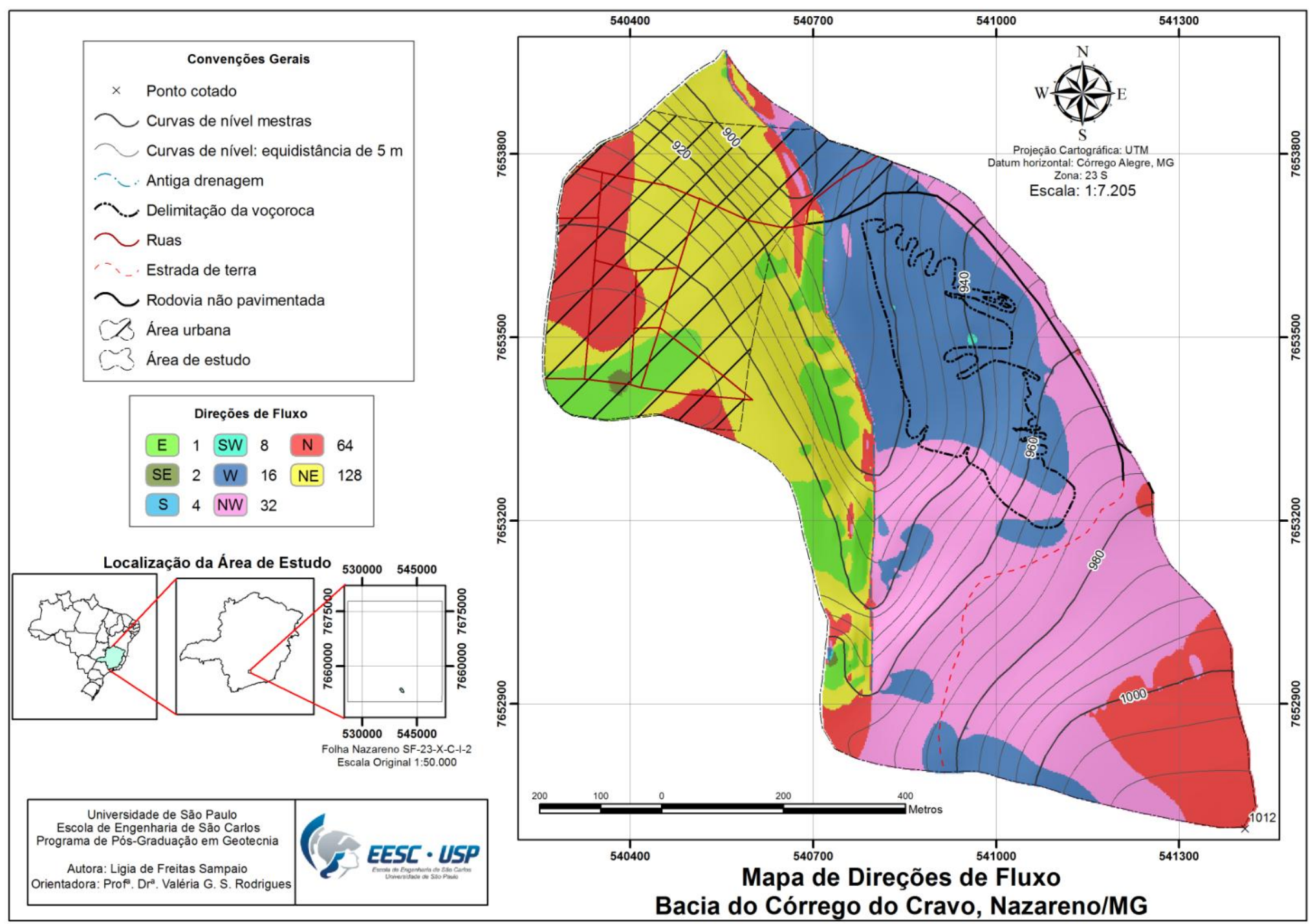

Figura 56 - Mapa de direções de fluxo, da bacia do Córrego do Cravo, Nazareno/MG. 
Na Figura 54, nota-se que a bacia do Córrego do Cravo apresenta altitudes entre 900 a $1000 \mathrm{~m}$, sendo que a voçoroca do Córrego do Cravo se encontra entre as classes hipsométricas de 900 a 980 m. A Tabela 14 exibe a relação das áreas encontradas para cada intervalo de classe hipsométrica.

Tabela 14 - Relação das áreas encontradas para cada intervalo de classe hipsométrica na bacia do Córrego do Cravo, Nazareno/MG.

\begin{tabular}{ccc}
\hline Classe Hipsométrica $(\mathbf{m})$ & Área $\left(\mathbf{m}^{\mathbf{2}}\right)$ & Porcentagem $(\%)$ \\
\hline$<900$ & $22.924,00$ & 3,01 \\
$900-920$ & $92.612,00$ & 12,17 \\
$920-940$ & $172.232,00$ & 22,64 \\
$940-960$ & $196.556,00$ & 25,83 \\
$960-980$ & $125.844,00$ & 16,54 \\
$980-1000$ & $86.604,00$ & 11,38 \\
$>1000$ & $64.060,00$ & 8,42 \\
\hline Total & $\mathbf{7 6 0 . 8 3 2 , 0 0}$ & $\mathbf{1 0 0 , 0 0}$
\end{tabular}

Na Tabela 14, pode-se observar que quase metade da área na qual se insere a bacia do Córrego do Cravo se encontra entre 920 e 960 m de altitude. As menores porcentagens da área total da bacia foram observadas para a menor $(<900 \mathrm{~m})$ e maior $(>1000 \mathrm{~m})$ altitude, respectivamente.

Quanto à declividade, de acordo com a Figura 55, na voçoroca do Córrego do Cravo ocorre o predomínio da classe de 8 a $20 \%$, sendo que também é encontrada a classe de 20 a $45 \%$.

A Tabela 15 exibe as proporções das áreas que se encontram as classes de declividade. Verifica-se que mais de $50 \%$ da bacia do Córrego do Cravo se encontra em declividades entre 8 e $20 \%$, e 22,56\% se encontram entre 3 e $8 \%$. A classe de declividade de 20 a $45 \%$ apresenta 13,38 \% da área total da bacia do Córrego do Cravo. 
Tabela 15 - Relação das áreas encontradas para as classes de declividade na bacia do Córrego do Cravo, Nazareno/MG.

\begin{tabular}{ccc}
\hline Declividade $(\boldsymbol{\%})$ & Área $\left(\mathbf{m}^{\mathbf{2}}\right)$ & Porcentagem $(\boldsymbol{\%})$ \\
\hline $0-3$ & $57.532,00$ & 7,56 \\
$3-8$ & $171.664,00$ & 22,56 \\
$8-20$ & $429.732,00$ & 56,48 \\
$20-45$ & $101.808,00$ & 13,38 \\
$45-750$ & 96,00 & 0,01 \\
\hline Total & $\mathbf{7 6 0 . 8 3 2 , 0 0}$ & $\mathbf{1 0 0 , 0 0}$ \\
\hline
\end{tabular}

Na porção próxima ao cafezal e da estrada de terra (montante) a direção preferencial do fluxo é NW, sendo que no restante da voçoroca do Córrego do Cravo predomina a direção W (Figura 56). A Tabela 16 confirma que 33,46\% de todo o fluxo que pode escoar na bacia aponta para a direção NW, demonstrando que esta é a direção preferencial para o deflúvio. Em termos de relação de área a direção de fluxo W corresponde a 21,97 \% da bacia do Córrego do Cravo.

Tabela 16 - Relação das áreas encontradas para as direções de fluxo na bacia do Córrego do Cravo, Nazareno/MG.

\begin{tabular}{ccc}
\hline Direção de fluxo & Área $\left(\mathbf{m}^{\mathbf{2}}\right)$ & Porcentagem $(\boldsymbol{\%})$ \\
\hline$(\mathrm{E})$ & $52.420,00$ & 6,89 \\
$(\mathrm{SE})$ & $1.384,00$ & 0,18 \\
$(\mathrm{~S})$ & 32,00 & 0,00 \\
$(\mathrm{SW})$ & 320,00 & 0,04 \\
$(\mathrm{~W})$ & $167.192,00$ & 21,97 \\
$(\mathrm{NW})$ & $254.580,00$ & 33,46 \\
$(\mathrm{~N})$ & $117.812,00$ & 15,48 \\
$(\mathrm{NE})$ & $167.092,00$ & 21,96 \\
\hline Total & $\mathbf{7 6 0 . 8 3 2 , 0 0}$ & $\mathbf{1 0 0 , 0 0}$ \\
\hline
\end{tabular}


Nota-se, também, que a rodovia não pavimentada que faz limite com a voçoroca localiza-se na direção perpendicular às curvas de nível e muito próxima, em momentos, coincidente, com o divisor de águas desta bacia (Figura 56); esta observação ilustra o fato de que esta rodovia também está contribuindo com a concentração do escoamento superficial em direção à voçoroca. Em campo, caminhando-se nesta rodovia, foi possível observar esta consideração e constatar os efeitos desta concentração: mais próximo à região de jusante se observa que um dos braços da voçoroca tem início em um ponto ligado ao escoamento advindo da estrada, e ao percorrer-se este ponto, são observados vários locais em que já foram removidos os sedimentos, apresentando grandes buracos que aumentam de dimensões à medida em que se continua avançando em direção a este braço da voçoroca. A Figura 57 apresenta o caminho do escoamento advindo da estrada de terra para a voçoroca, caracterizado pela remoção do solo e a presença de buracos.

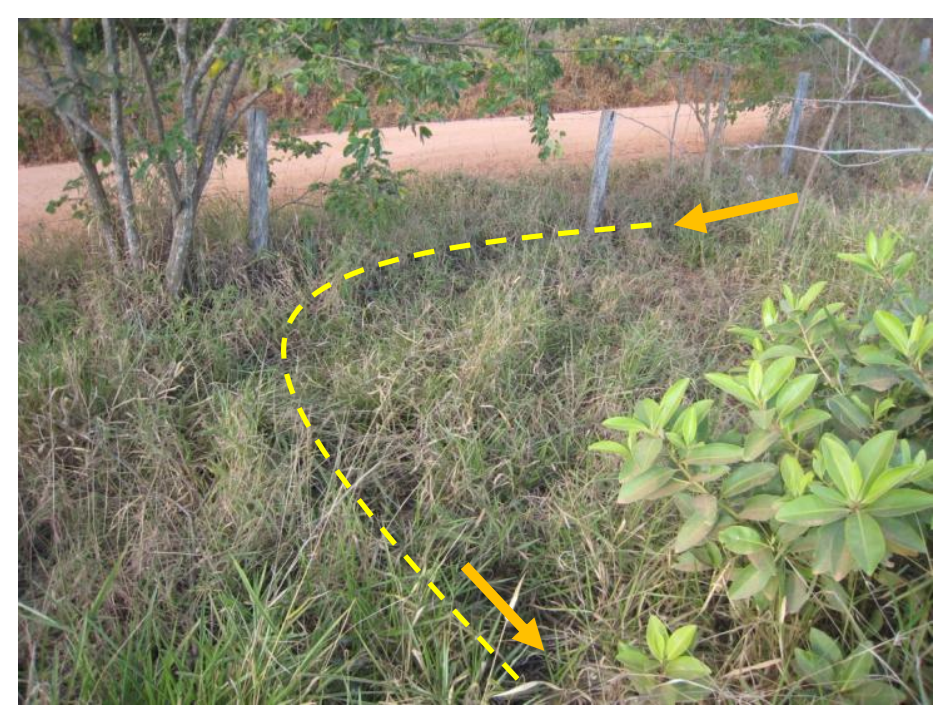

Figura 57 - Escoamento direto da estrada para a voçoroca do Córrego do Cravo, Nazareno/MG.

Na campanha de campo também foi possível visualizar a configuração atual do uso e ocupação da área da voçoroca do Córrego do Cravo (Figura 58). 


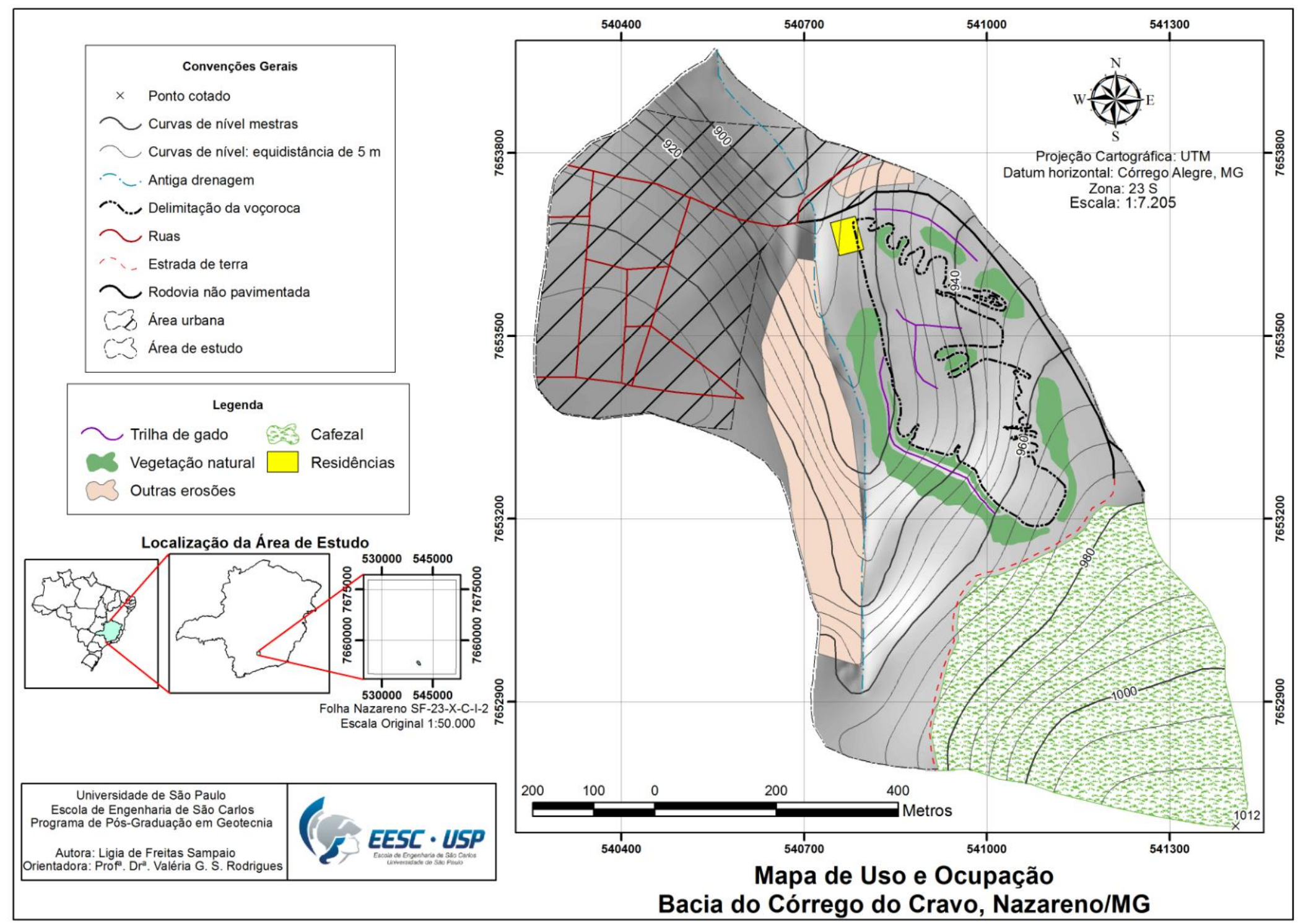

Figura 58 - Uso e ocupação da bacia do Córrego do Cravo, Nazareno/MG. 
Observa-se (Figura 58) que a voçoroca do Córrego do Cravo se encontra cercada pela expansão e atividades rurais e urbanas: no limite à montante, verifica-se a presença de cultura de café muito próxima à borda da voçoroca; seus dois limites laterais se encontram em utilização por tráfego, tanto da população (na presença da estrada de terra) como de animais (com as trilhas de gado); em sua base, verifica-se a construção e avanço de residências. Este tipo de relação com o uso do solo demonstra que existe certo descaso da população, com a recuperação do ambiente e com a problemática do avanço deste processo erosivo; mesmo com o esforço e dedicação do Projeto Maria de Barro, por ser algo que está presente há muito tempo na área e que se desenvolve lentamente, talvez somente se perceba que a voçoroca ainda apresenta processos ativos e risco iminente conforme ocorra algum incidente maior, como os deslizamentos verificados em 2012.

Outro fator importante na área, além dos anteriormente citados, é com relação aos solos e relevo. O Anexo 04 apresenta duas seções geológicas geradas para compreensão da distribuição dos solos e do contraste apresentado para a área da voçoroca em relação à conformação do relevo.

Na Seção AB (Anexo 04) observa-se que a voçoroca do Córrego do Cravo removeu em sua maior parte o solo saprolítico que se encontrava em altitudes mais baixas; sendo mantida exposta uma grande área deste solo, deixando-se o Latossolo sem sua base e com o afloramento do nível d'água (N.A.) subterrâneo, é possível considerar que a ocorrência dos processos erosivos são remontantes na área. Ou seja, observa-se que o volume de solo que sustentava o perfil, removido pelos processos erosivos, deixou ainda mais exposto o horizonte de solo saprolítico de elevada susceptibilidade à erosão (pouco coeso e friável, como observado no campo), e o contato com nível d'água agrava a remoção e transporte deste solo. Este processo desestabiliza a região à montante, fornecendo condições para a ocorrência de escorregamentos e a formação de fendas no solo; caso continue sem a devida mitigação ou estabilização, este processo pode causar prejuízos off site: além da própria voçoroca, a erosão avança para a propriedade em que se encontra o cafezal, pois tende a se deslocar para esta área.

Em relação à Seção CD (Anexo 04), observa-se que, próximo à montante da voçoroca, grande parte do Latossolo também foi removido, e a exposição do saprolito que anteriormente não mantinha contato com as variações e ações climáticas combinada com o contato do nível 
d'água subterrâneo, levam à desestabilização do solo na parte interna da voçoroca. Verificase, então, que esta dinâmica de remoção, exposição e desestabilização do solo susceptível ocorre tanto longitudinal como transversalmente.

\subsection{Ensaios Laboratoriais}

\subsubsection{Ensaio de Condutividade Hidráulica a CARga Constante}

O ensaio de condutividade hidráulica foi realizado a carga constante de $27 \mathrm{~cm}$ com as amostras LAT T3 e SAP P 7 (representativas dos Latossolos e Saprolitos). Durante a realização do ensaio, percebeu-se que a amostra LAT T3 apresentou escoamento extremamente rápido, indicando que alguma alteração poderia ter ocorrido com a amostra. Ao final do ensaio, procedeu-se à abertura dos amostradores, cerrando-os longitudinalmente, para observação da existência ou não de caminhos preferenciais de escoamento ou modificações na estrutura da amostra. Verificou-se que a amostra SAP P 7 se encontrava bem aderida às paredes do amostrador, e que a amostra LAT T3 se encontrava com menor adesão, apontando caminho preferencial da água nas paredes do amostrador. Diante disso, somente o resultado obtido com o solo saprolítico pode ser considerado neste trabalho, ressaltando-se que uma caracterização mais acurada dos valores da condutividade hidráulica dos solos da área de estudo poderia ser realizada através de ensaios in situ ou com maior detalhamento da amostragem em diversas réplicas e locais (o que não foi realizado devido a dificuldade em retirar amostras indeformadas, sem fissuras e raízes).

Foram encontrados os seguintes resultados para a amostra de solo saprolítico SAP P 7 no ensaio:

- Área da seção do amostrador de 74,20 m²;

- Vazão média no ensaio de $0,0374 \mathrm{~cm}^{3} \cdot \mathrm{s}^{-1}$;

- Tempo de duração de cada medida, constante, de 60 segundos;

- Altura de carga disponível de $27 \mathrm{~cm}$;

- Gradiente hidráulico constante de 3; 
- Condutividade hidráulica média encontrada de $1,68 \cdot 10^{-4} \mathrm{~cm} \cdot \mathrm{s}^{-1}$ ou $1,68 \cdot 10^{-6}$ $\mathrm{m} \cdot \mathrm{s}^{-1}$.

Observando-se o andamento e o resultado do ensaio, pode-se afirmar que o solo saprolítico SAP P 7 possui condutividade hidráulica de média a baixa. Esta característica pode ser correlacionada com o comportamento observado durante o ensaio de erodibilidade, em que os solos saprolíticos foram os que apresentaram absorção de água mais lenta em comparação com as amostras de Latossolo. Esta condutividade hidráulica, também é confirmada na avaliação obtida com ensaio MCT (Miniatura, Compactada, Tropical), detalhado no Tópico 6.2.5.

\subsubsection{ENSAIO DE ERODIBILIDADE}

O ensaio de erodibilidade foi realizado com as amostras LAT T3, SAP 1, SAP 2, SAP TX 3, SAP P 5, SAP P 7 e SAP P 8, e os resultados são apresentados no Gráfico 7.

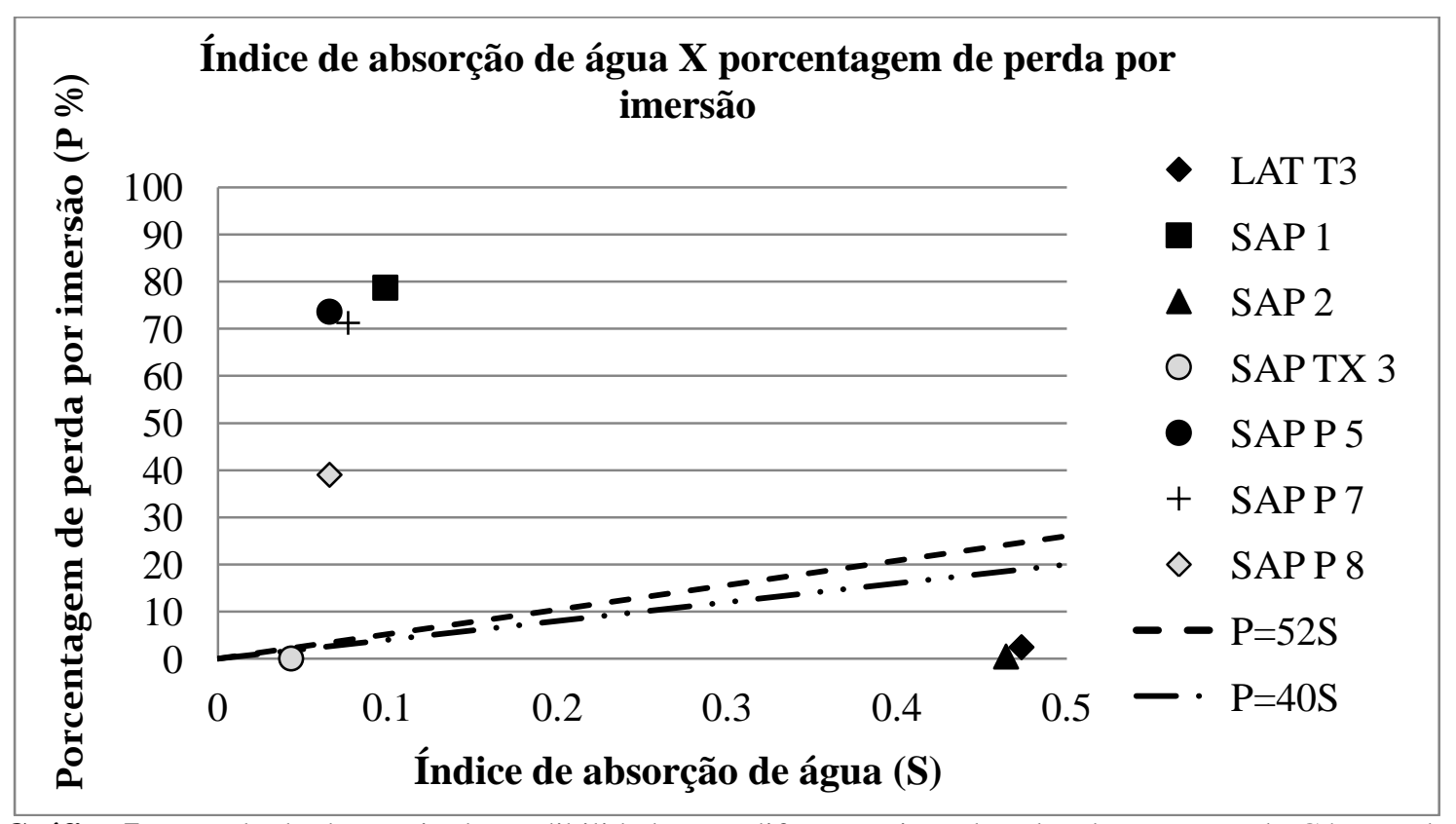

Gráfico 7 - Resultado do ensaio de erodibilidade com diferentes tipos de solos da voçoroca do Córrego do Cravo, Nazareno/MG. 
Os resultados deste ensaio, comparados tanto com o critério de Nogami e Villibor (1979 apud Pejon, 1992), no qual o índice de absorção de água $S$ é relacionado em proporção de 52 com a porcentagem de perda por imersão $P$, e com o critério de Pejon (1992), no qual esta proporção é de 40, apontam que os solos saprolíticos, com exceção de SAP 2 e SAP TX 3, são os mais erodíveis, por se apresentarem acima das retas obtidas com as proporções citadas (Gráfico 7). Este fato pode ser conectado com a menor velocidade observada na absorção de água destes solos durante o ensaio e com a maior perda de solo por imersão em relação aos que apresentaram menor erodiblidade. Ou seja, estes solos possuem maior susceptibilidade aos processos erosivos, confirmando o que foi afirmado em Curi (1991 apud Horta, 2006) e em Ferreira (2005).

Morais, Bacellar e Sobreira (2005), em análise de erodibilidade realizada em solos saprolíticos (embasamento gnáissico) finamente bandado da região de Ouro Preto (MG), apontam maior potencialidade para erosão em piping nestes tipos de solo em relação ao transporte no escoamento superficial, e que as estruturas em bandamentos dos saprolitos não influenciaram a erodibilidade nas diferentes direções destes.

A amostra LAT T3, advinda de Latossolo com elevada porcentagem de matéria orgânica (Tópico 6.2.4), a amostra SAP 2, que, mesmo sendo de solo saprolítico também apresentou elevada quantidade de matéria orgânica, e a amostra SAP TX 3, que apresenta grande estabilidade e reduzida friabilidade, exibiram elevada velocidade de absorção de água durante o ensaio. Segundo Pejon (1992), esta característica aponta para a diminuição do escoamento superficial, já que a infiltração é maior, e, em consequência, reduz a potencialidade de ocorrer erosão. Os valores de perda de material por imersão revelaram-se serem os menores $(2,48,0,51$ e $0,09 \%$, respectivamente), o que indica a menor destacabilidade destes solos. Morais, Bacellar e Sobreira (2005) apontam que os horizontes B latossólicos de solos derivados de gnaisses da região de Ouro Preto são menos susceptíveis à erosão que os saprolitos; Menezes et al. (2009) também apontam para a maior susceptibilidade à erosão dos Cambissolos (saprolitos) em relação aos Latossolos na região de uma sub-bacia da bacia do Alto Rio Grande. 


\subsubsection{ENSAIO DE $\triangle \mathrm{PH}, \mathrm{CE}$ E EH}

Os resultados obtidos no ensaio de $\Delta \mathrm{pH}$, condutividade elétrica (CE) e potencial de oxi-redução (Eh) com as amostras coletadas na voçoroca do córrego do Cravo em Nazareno são apresentados na Tabela 17.

Tabela 17 - Resultados do ensaio de $\Delta \mathrm{pH}\left(\mathrm{pH}_{\mathrm{KCl}}\right.$ e $\left.\mathrm{pH}_{\mathrm{H} 2 \mathrm{O}}\right)$, CE e Eh.

\begin{tabular}{c|c|c|c|c|c}
\hline Amostra & $\mathbf{p H}_{\mathbf{K C l}}$ & $\mathbf{p H}_{\mathbf{H 2 O}}$ & $\boldsymbol{\Delta p H}$ & $\mathbf{C E}\left(\boldsymbol{\mu S . \mathbf { c m } ^ { - 1 } )}\right.$ & $\begin{array}{c}\text { Eh } \\
(\mathbf{m V})\end{array}$ \\
\hline LAT 1 & 6,4 & 6,8 & $-0,4$ & 5,70 & $+221,00$ \\
\hline LAT T2 & 4,7 & 5,6 & $-0,9$ & 26,30 & $+257,00$ \\
\hline LAT T3 & 5,5 & 5,4 & 0,1 & 17,70 & $+288,00$ \\
\hline SAP 1 & 4,0 & 5,7 & $-1,7$ & 9,60 & $+294,00$ \\
\hline SAP 2 & 5,2 & 6,5 & $-1,3$ & 12,90 & $+217,00$ \\
\hline SAP TX 3 & 5,6 & 6,8 & $-1,2$ & 7,60 & $+214,00$ \\
\hline SAP TX 4 & 4,5 & 6,3 & $-1,8$ & 7,70 & $+245,00$ \\
\hline SAP P 5 & 4,4 & 6,4 & $-2,0$ & 9,40 & $+234,00$ \\
\hline SAP P 6 & 4,4 & 6,6 & $-2,2$ & 3,50 & $+230,00$ \\
\hline SAP P 7 & 4,6 & 7,2 & $-2,6$ & 2,70 & $+241,00$ \\
\hline SAP P 8 & 4,1 & 5,1 & $-1,0$ & 19,60 & $+335,00$ \\
\hline
\end{tabular}

LAT 1: solo residual laterítico retirado de encosta da voçoroca; LAT T2: solo residual laterítico retirado superficialmente (trincheira); LAT T3: solo residual laterítico retirado em $60 \mathrm{~cm}$ de profundidade (trincheira); SAP 1: solo saprolítico retirado de encosta da voçoroca; SAP 2: solo saprolítico retirado superficialmente; SAP TX 3: solo saprolítico de talco-xisto; SAP TX 4: solo saprolítico de talco-xisto retirado de encosta da voçoroca; SAP P 5: solo saprolítico quartzoso retirado próximo a um piping; SAP P 6: solo saprolítico arroxeado retirado próximo a um piping; SAP P 7: solo saprolítico de coloração variegada retirado próximo a um piping; SAP P 8: solo saprolítico de coloração rosa e branca retirado próximo a um piping.

Ao longo da voçoroca pode-se observar que os solos, lateríticos ou saprolíticos, se apresentam com pH em água com caráter predominantemente ácido a neutro, com uma variabilidade entre 5,1 a 7,2. Estes resultados são compatíveis com os obtidos por Embrapa (2006b), Horta (2006) e Ferreira et al. (2011), os quais apontam que, para os Latossolos do município, o pH em água varia de 4,8 a 6,4, e que, para os Cambissolos, estes valores se encontram entre 4,5 e 6,1. Leite (2001) comenta que valores de pH mais baixos, com concentração maior de íons $\mathrm{H}^{+}$, apontam para cargas positivas no sistema do solo.

Em relação ao $\Delta \mathrm{pH}\left(\mathrm{pH} \mathrm{KCl}-\mathrm{pH} \mathrm{H}_{2} \mathrm{O}\right)$, verifica-se que a grande maioria das amostras se apresentou com valores negativos, sendo que apenas a amostra LAT T3 mostrouse positiva (Tabela 17). Como em Silva (1990), em Latossolo Vermelho o $\Delta \mathrm{pH}$ se apresentou negativo mais próximo à superfície $(-0,4)$ e positivo em horizonte mais profundo $(0,1)$, compatível com o resultado apontado. Este autor também apresenta para o Latossolo 
Vermelho-Amarelo e para os Cambissolos, resultantes tanto de rejuvenescimento de Latossolos quanto de alteração de micaxistos e quartzitos, valores negativos para o $\Delta \mathrm{pH}$ (entre -0,1 e -0,8). Em contrapartida com o pH, Demattê (1989) apud Leite (2001) afirma que valores negativos para $\Delta \mathrm{pH}$ indicam que o solo apresenta cargas negativas preponderantemente, o que influencia na Capacidade de Troca Catiônica (CTC), sendo, portanto, uma característica de grande utilidade para se compreender este comportamento.

A partir da Tabela 17 também se observam baixos valores de CE, que variam entre 2,70 a 19,60 $\mu \mathrm{S} . \mathrm{cm}^{-1}$, sem apresentar um comportamento definido de acordo com o tipo de solo. A CE possui relação diretamente proporcional à quantidade de sais presentes na solução que ocupa os vazios do solo, sendo que é desta solução que as plantas retiram os elementos necessários ao seu metabolismo (BRANDÃO e LIMA, 2002). Caso haja excessiva quantidade de sais próximos às raízes, a germinação e o crescimento das espécies vegetais podem ser prejudicados (TOMÉ Jr., 1997 apud BRANDÃO e LIMA, 2002).

Em relação ao Eh, observa-se um comportamento oxidante das amostras, com valores variando de $+214,00$ a $+335,00 \mathrm{mV}$ (Tabela 17), valores estes adequados para solos da região.

O Gráfico 8 apresenta os resultados de Eh em comparação com pH, e em confronto com a Figura 59, adaptada de Krauscopf (1972 apud Leite, 2001), mostra que os solos, tanto lateríticos quanto saprolíticos da voçoroca do Córrego do Cravo, apresentam, em geral, comportamento oxidante ácido. 


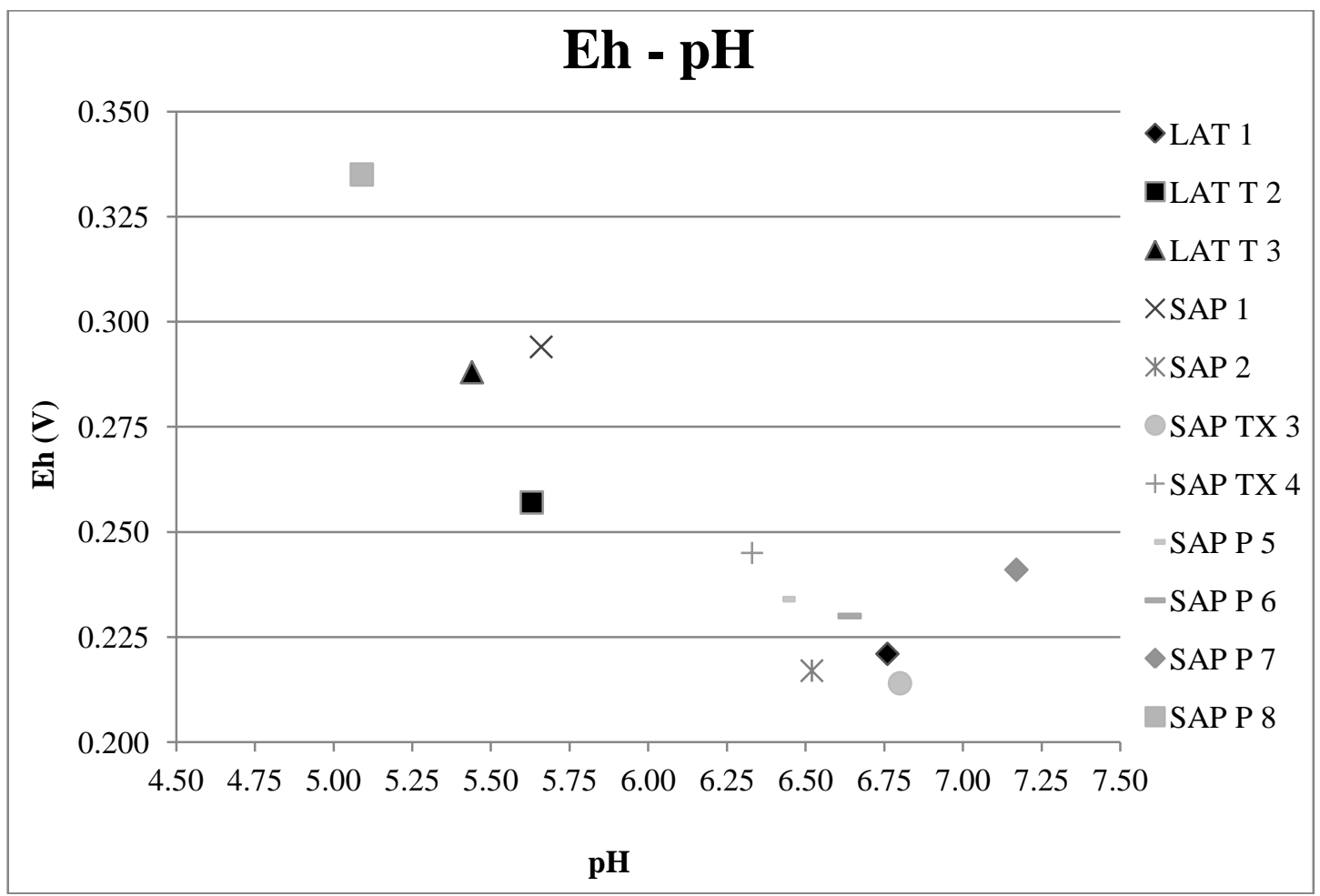

Gráfico 8 - Eh - pH: solos da voçoroca do Córrego do Cravo, Nazareno/MG.

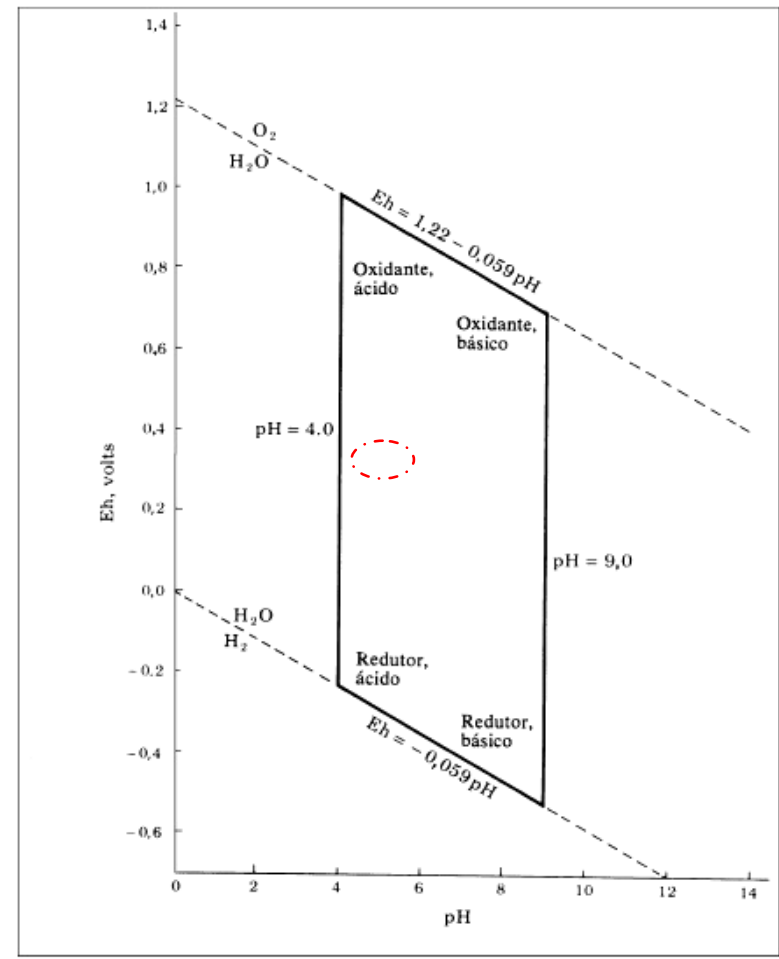

Figura 59 - Modelo de diagrama Eh- $p H$ : o paralelogramo inscrito representa os limites usuais encontrados na superfície da crosta terrestre. O círculo apresenta a localização dos resultados para os solos da voçoroca do Córrego do Cravo em Nazareno/MG. Adaptado de Krauscopf (1972 apud Leite, 2001). 


\subsubsection{ENSAIO DE OXIDAÇÃO DE MATÉRIA ORGÂNICA}

A Tabela 18 apresenta os resultados do ensaio de obtenção da porcentagem de matéria orgânica em diferentes amostras retiradas ao longo da voçoroca do Córrego do Cravo, em Nazareno (MG).

Tabela 18 - Resultados do ensaio de oxidação da matéria orgânica no solo.

\begin{tabular}{c|c}
\hline Amostra & $\begin{array}{c}\text { Matéria Orgânica } \\
(\%)\end{array}$ \\
\hline LAT 1 & 3,1 \\
\hline LAT T & 7,8 \\
\hline LAT T3 & 5,3 \\
\hline SAP 1 & 1,8 \\
\hline SAP 2 & 4,5 \\
\hline SAP TX 3 & 1,5 \\
\hline SAP TX 4 & 2,9 \\
\hline SAP P 5 & 2,3 \\
\hline SAP P 6 & 2,4 \\
\hline SAP P 7 & 2,4 \\
\hline SAP P 8 & 1,4 \\
\hline
\end{tabular}

LAT 1: solo residual laterítico retirado de encosta da voçoroca; LAT T2: solo residual laterítico retirado superficialmente (trincheira); LAT T3: solo residual laterítico retirado em $60 \mathrm{~cm}$ de profundidade (trincheira); SAP 1: solo saprolítico retirado de encosta da voçoroca; SAP 2: solo saprolítico retirado superficialmente; SAP TX 3: solo saprolítico de talco-xisto; SAP TX 4: solo saprolítico de talco-xisto retirado de encosta da voçoroca; SAP P 5: solo saprolítico quartzoso retirado próximo a um piping; SAP P 6: solo saprolítico arroxeado retirado próximo a um piping; SAP P 7: solo saprolítico de coloração variegada retirado próximo a um piping; SAP P 8: solo saprolítico de coloração rosa e branca retirado próximo a um piping.

Observa-se pela Tabela 18 que as amostras de Latossolo apresentaram os maiores teores de matéria orgânica. A amostra LAT 1, retirada da encosta onde houve movimento de massa, apresentou o menor valor $(3,1 \%)$ dentre os Latossolos; já a amostra LAT T2, retirada mais próxima da superfície (na trincheira aberta para a coleta), apresentou o maior valor (7,8\%). A amostra LAT T3, retirada a uma profundidade de $60 \mathrm{~cm}$ (trincheira), apresentou valor intermediário (5,3\%) entre elas. Silva (1990), utilizando metodologia de Vettori (1969) e Embrapa (1979), encontrou valores de 2 a 3,6\% para Latossolos Vermelhos e 1,6 a 3,6\% para Latossolos Vermelho-amarelos da região de Lavras, enquanto Horta (2006), utilizando metodologia da Embrapa (1997), encontrou valores de 490 g. $\mathrm{kg}^{-1}$ para Latossolos Vermelhos e 25 g. $\mathrm{kg}^{-1}$ para Latossolos Vermelho-amarelos em Nazareno. Estas quantidades mais elevadas de matéria orgânica caracterizam aumento na agregação das partículas e na 
permeabilidade para estes solos, o que reduz o escoamento superficial e aumenta a resistência à erosão em relação aos outros (SILVA, 1990).

Em relação aos solos saprolíticos (Cambissolo), pode-se observar que esses possuem baixos teores de matéria orgânica (entre 1,4 e 2,9 \%), sendo que a amostra SAP 2 exibiu maior valor $(4,5 \%)$ em relação às outras. Ao se observar qualitativamente, esta amostra possuía coloração mais escura e apresentava mais raízes em relação às outras amostras de saprolito, o que pode ter influenciado neste resultado. Porém, verificando os resultados de 0,6 a 4,4\% de Silva (1990), 15 a 24 g.kg ${ }^{-1}$ de Horta (2006), 1,37 a 1,87 dag.kg ${ }^{-1}$, de Ferreira (2008), 0,9 a 2,6 dag. $\mathrm{kg}^{-1}$ de Ferreira et al. (2011), depreende-se que existe variabilidade de resultados nesse caso, e que, independentemente da origem dos Cambissolos (rejuvenescimento de Latossolo, micaxistos e quartzitos ou gnaisses graníticos) e dos tipos de manejo agropecuários utilizados, estes solos se apresentam com teores de matéria orgânica menores que os Latossolos. Silva (1990) atribui esta característica à possibilidade de estes solos serem mais saturados em alumínio, e que, mesmo com presença de matéria orgânica, seu efeito na estabilização do solo e na permeabilidade é reduzido pela presença de silte e areia fina que favorecem o encrostamento; associados às elevadas declividades, estes fatores predominam sobre os outros e diminuem a resistência destes solos. Em complemento, Ferreira (2008) afirma que a drenagem para estes tipos de solos poderia ser melhorada com a inserção de carbono orgânico e que isto também poderia contribuir para sua estabilização.

6.2.5 Ensaio de ClassificaÇão de Solos - Miniatura, Compactada, Tropical (MCT) E ANÁLISE GRANULOMÉTRICA CONJUNTA

No ensaio de classificação Miniatura, Compactada, Tropical (MCT), foram utilizadas as amostras de solo LAT 1 e SAP P 7, com a finalidade de avaliar as diferenças entre o solo laterítico e o saprolítico. A Tabela 19 foi utilizada para comparação dos dados e interpretação da classificação MCT qualitativamente. 
Tabela 19 - Classificação MCT e dados diversos dos grupos de solos integrantes da mesma (Modificada de NOGAMI e VILLIBOR, 1995).

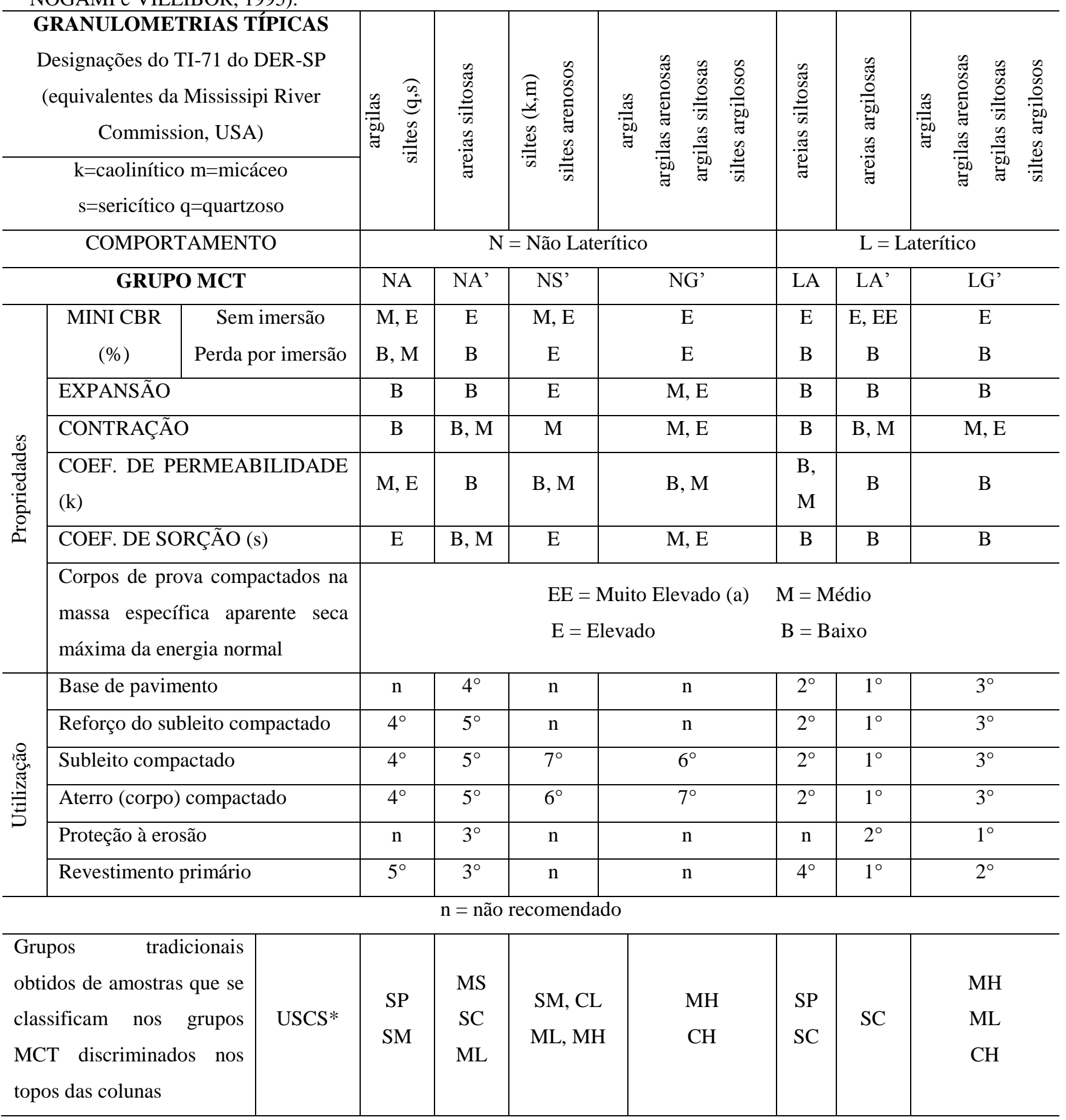

*Siglas detalhadas a seguir retiradas de KALINSKI (2011):

Primeiras letras: $\mathrm{S}=$ sand (areia); $\mathrm{M}=$ silt/muck (silte); $\mathrm{C}=$ clay(argila).

Segundas letras: $\mathrm{P}=$ poorly graded (pouco graduado); $\mathrm{M}=$ silty (siltoso); $\mathrm{S}=$ não descrito; $\mathrm{C}=$ clayey (argiloso); $\mathrm{L}=$ low-plasticity (lean) (baixa plasticidade - delgada); $\mathrm{H}=$ high-plasticity (fat) (elevada plasticidade - gorda).

Para a amostra LAT 1, foram encontrados o coeficiente $c^{\prime}$ (argilosidade do solo) igual

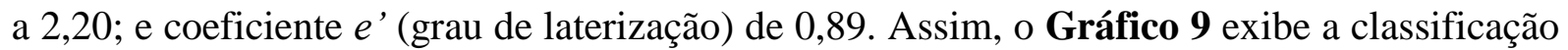
MCT desta amostra. 


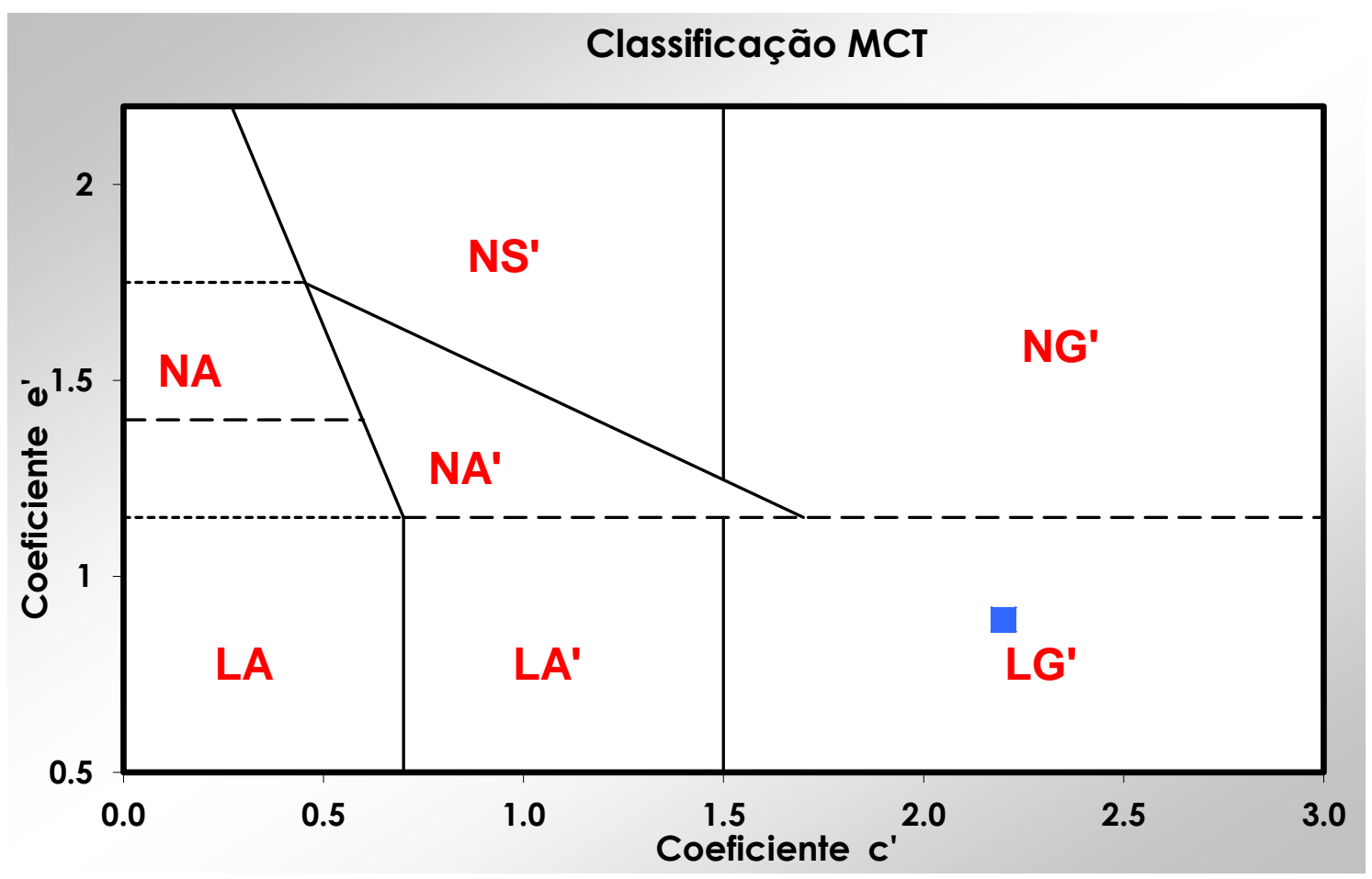

Gráfico 9 - Classificação MCT da amostra de Latossolo LAT 1, Nazareno/MG.

Sendo assim, considera-se que a amostra LAT 1 é enquadrada no parâmetro $L G^{\prime}$, o qual pode representar argilas, argilas arenosas, argilas siltosas e siltes argilosos, de comportamento laterítico argiloso (Gráfico 9). Partindo-se da Tabela 19, pode-se atribuir as propriedades de baixa expansão e média a elevada contração, baixo coeficiente de permeabilidade, baixo coeficiente de sorção. Comparando-se com a classificação da Unified Soil Classification System (USCS), esse solo se enquadra em MH (siltes de elevada plasticidade), ML (silte de baixa plasticidade) ou $\mathrm{CH}$ (argilas de elevada plasticidade), ou seja, solos de granulometria fina (KALINSKI, 2011).

Os solos de comportamento laterítico comumente apresentam-se com cores vermelha e/ou amarela, com elevada espessura e agregação das partículas finas, com aparência porosa ou com presença de trincas, e com pouca variação ao longo de um perfil (material mais homogêneo). Estes tipos de solos podem exibir diversidade de ganulometria e, em geral, podem apresentar comportamentos como elevada porosidade aparente natural, baixa resistência e baixa capacidade de suporte, quando encontrado em campo. Entretanto, quando houver compactação de forma adequada, podem apresentar grande resistência e capacidade de suporte, e baixa permeabilidade (NOGAMI e VILLIBOR, 1995). Estes comportamentos podem ser visualizados em campo: o Latossolo presente na área da voçoroca do Córrego do Cravo se apresenta com cor avermelhada típica, com espessura elevada, podendo-se visualizar 
trincas e características porosas. Apesar de a camada superficial apresentar elevada resistência, observa-se com o manuseio, após sua retirada, a friabilidade ao toque, a qual pode se relacionar com a característica de menor resistência mencionada acima; contudo, as estradas de terra que a circunvizinham, tanto a do cafezal quanto a do lado exterior, corroboram o fato de que, ao ser compactado, este solo exibe elevada resistência. A baixa permeabilidade, mencionada anteriormente, observada na avaliação qualitativa para este ensaio, pode ser correlacionada com o aumento dos processos erosivos causados pela concentração do escoamento superficial advindo das estradas de terra.

Os resultados da análise granulométrica conjunta e da massa específica da amostra LAT 1 são apresentados na Tabela 20.

Tabela 20 - Análise granulométrica conjunta e massa específica dos sólidos de amostra de solo laterítico LAT 1 - voçoroca do Córrego do Cravo, Nazareno/MG.

\begin{tabular}{ccc}
\hline Amostra & Análise granulométrica & $\begin{array}{c}\text { Massa específica dos } \\
\text { sólidos }\left(\mathbf{2 0}^{\circ} \mathbf{C}-\mathbf{g . c m}^{-\mathbf{3}}\right)\end{array}$ \\
\hline LAT 1 & Silte: $28 \%$ & \\
& Areia fina: $14 \%$ & 2,895 \\
& Areia média: $7 \%$ & \\
& Areia grossa: $1 \%$ & \\
\hline
\end{tabular}

A Tabela 20 confirma que este tipo de solo apresenta granulometria fina (78\% de finos); a massa específica de $2,895 \mathrm{~g} \cdot \mathrm{cm}^{-3}$ aponta para a presença de concreções lateríticas na amostra. Nogami e Villibor (1995) identificaram concreções lateríticas em Latossolos Vermelhos (Figura 60), similar ao solo estudado nesta pesquisa.

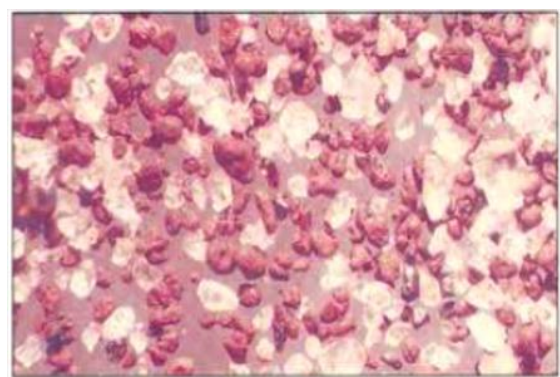

Figura 60 - Latossolo Vermelho, com concreções de argila laterítica (NOGAMI e VILLIBOR, 1995). 
Para a amostra SAP P 7, foram encontrados o coeficiente $c$ ' igual a 0,70; e coeficiente $e^{\prime}$ de 1,17. Assim, considera-se esta amostra como $N A$ ', de comportamento não laterítico arenoso, segundo a classificação MCT (Gráfico 10).

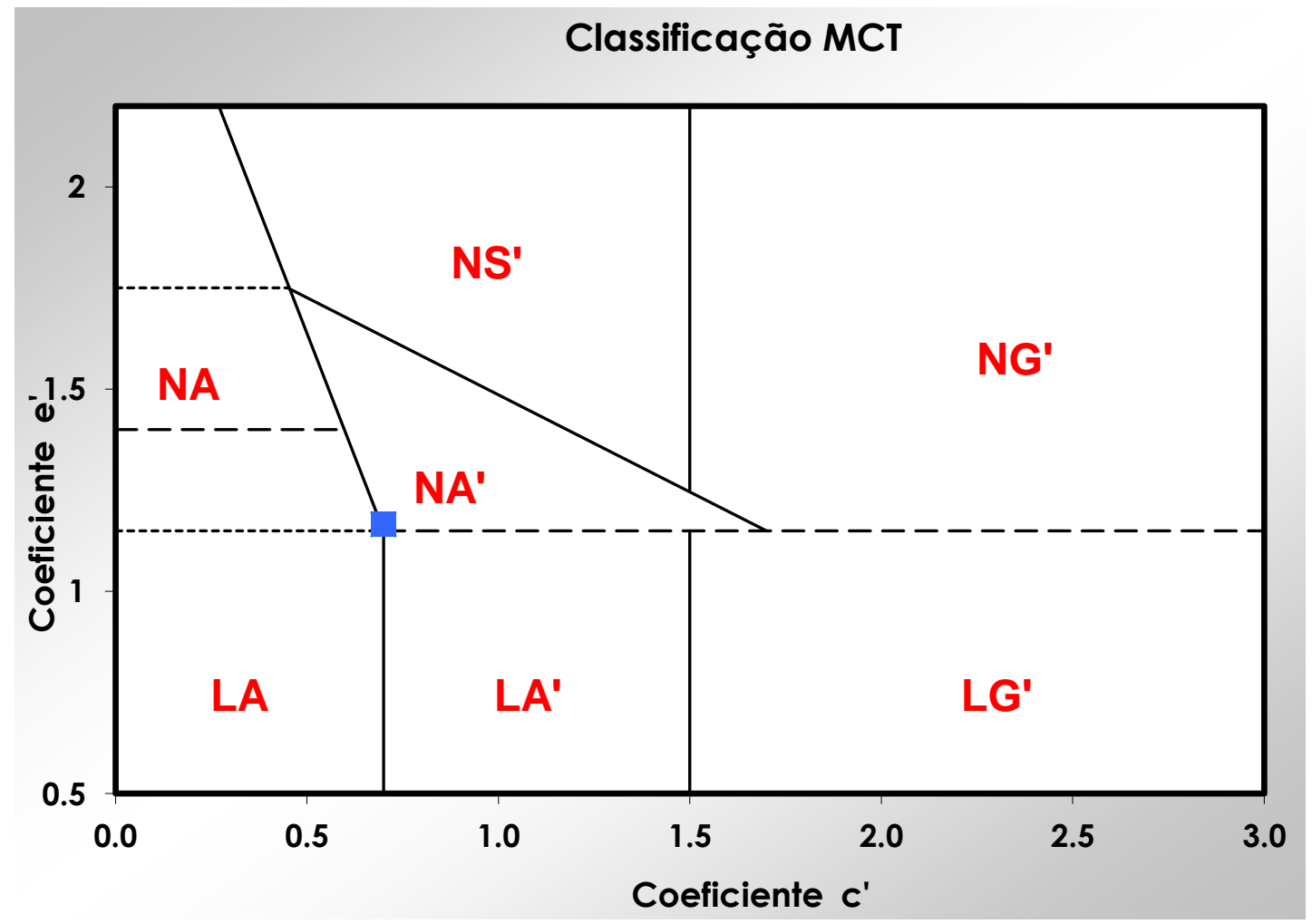

Gráfico 10 - Classificação MCT da amostra de solo saprolítico SAP P 7, Nazareno/MG.

Os solos não lateríticos apresentam elevada diversidade de comportamento. Sendo assim, os solos saprolíticos que se incluem nesta classificação devem exibir características relacionadas diretamente tanto com a rocha matriz como com o grau de alteração em que se encontram, sendo considerado difícil generalizarem-se quaisquer propriedades que possam apresentar (NOGAMI e VILLIBOR, 1995). Diante disso, utilizando-se a Tabela 19 para uma avaliação qualitativa da amostra, em comparação com observações em campo, pode-se considerar que a amostra SAP P 7 apresenta, em geral, fração granulométrica areia-siltosa, baixa expansão, baixa a média contração, coeficiente de permeabilidade baixo, e baixo a médio coeficiente de sorção. Comparando-se esta amostra com os solos saprolíticos utilizados no ensaio de erodibilidade, observou-se que os mesmos apresentaram comportamento similar em relação à perda de massa por imersão, pois em ambos os ensaios houve significativa perda quando em contato com a água. Ainda, no ensaio de erodibilidade (anteriormente descrito) observou-se que estes tipos de solo apresentavam velocidade muito reduzida de absorção de 
água, o que corrobora o que foi verificado no ensaio de condutividade hidráulica e com a afirmação contida na Tabela 19. Em comparação com a classificação da USCS, esses solos podem ser relacionados com os grupos SC (areia argilosa) e ML (silte com baixa plasticidade) (KALINSKI, 2011).

Os resultados da análise granulométrica conjunta e da massa específica são exibidos na Tabela 21.

Tabela 21 - Análise granulométrica conjunta e massa específica dos sólidos de amostras de solo saprolítico SAP. Voçoroca do Córrego do Cravo, Nazareno/MG.

\begin{tabular}{ccc}
\hline Amostra & Análise granulométrica & $\begin{array}{c}\text { Massa específica dos } \\
\text { sólidos }\left(\mathbf{2 0}^{\circ} \mathbf{C}-\mathbf{g . c m}^{\mathbf{3}}\right)\end{array}$ \\
\hline Argila: $4 \%$ & \\
SAP P 7 & Silte: $61 \%$ & 2,649 \\
& Areia fina: $19 \%$ & \\
Areia média: $15 \%$ & \\
\hline
\end{tabular}

Verifica-se que esta amostra possui predominantemente a fração silte, seguida de areia fina. Esta granulometria condiz com o que foi encontrado no ensaio MCT, e corrobora a elevada erodibilidade deste tipo de solo, pois a presença de silte em maiores proporções facilita seu desgaste e arraste com o escoamento concentrado da água, já que estas partículas não se cimentam como as argilas. O resultado da massa específica se encontra muito próximo do valor comumente atribuído ao quartzo (2,65 g. $\left.\mathrm{cm}^{-3}\right)$ (KALINSKI, 2011), o que aponta para a presença deste tipo de mineral em grandes proporções; a Figura 61 apresenta um exemplo da configuração de um solo saprolítico que pode ser comparado à amostra SAP P7. 


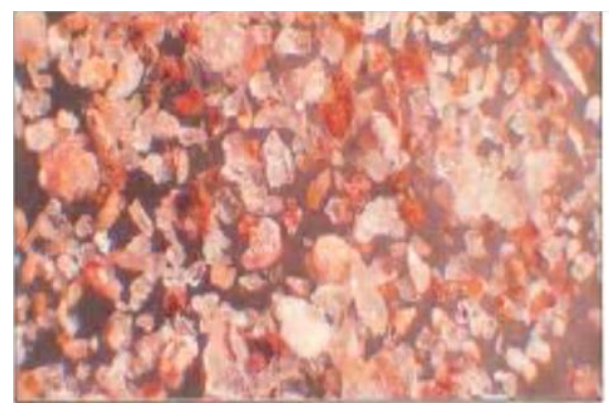

Figura 61 - Solo saprolítico de micaxisto, com quartzo e mica intemperizada (NOGAMI e VILLIBOR, 1995).

\subsubsection{Microscopia Eletrônica de Varredura (MEV) E Espectroscopia de ENERGIA DISPERSIVA (EDS)}

A forma dos grãos e as características mineralógicas do solo são importantes no que se refere ao conhecimento de sua origem e pedologia. Este conhecimento se torna importante à medida que proporciona, além da ilustração das estruturas de herança das rochas de origem, também a compreensão de comportamentos particulares dos solos tropicais (NOGAMI e VILLIBOR, 1995).

Primeiramente, em lupa, foi possível escolher as amostras com algumas características que poderiam diferir entre si para realização das análises de Microscopia Eletrônica de Varredura (MEV) e de Espectroscopia de Energia Dispersiva (EDS). Assim, foram utilizadas as amostras LAT T3, SAP 1, SAP 2, SAP TX 3, SAP P 5, SAP P 6 e SAP P 8. Os resultados serão apresentados para cada amostra.

\section{LAT T3}

A amostra LAT T3 foi ampliada para a observação de sua estrutura (Figura 62). A análise semiquantitativa é apresentada através da Figura 63 com os EDS e das porcentagens dos elementos (Tabela 22). 


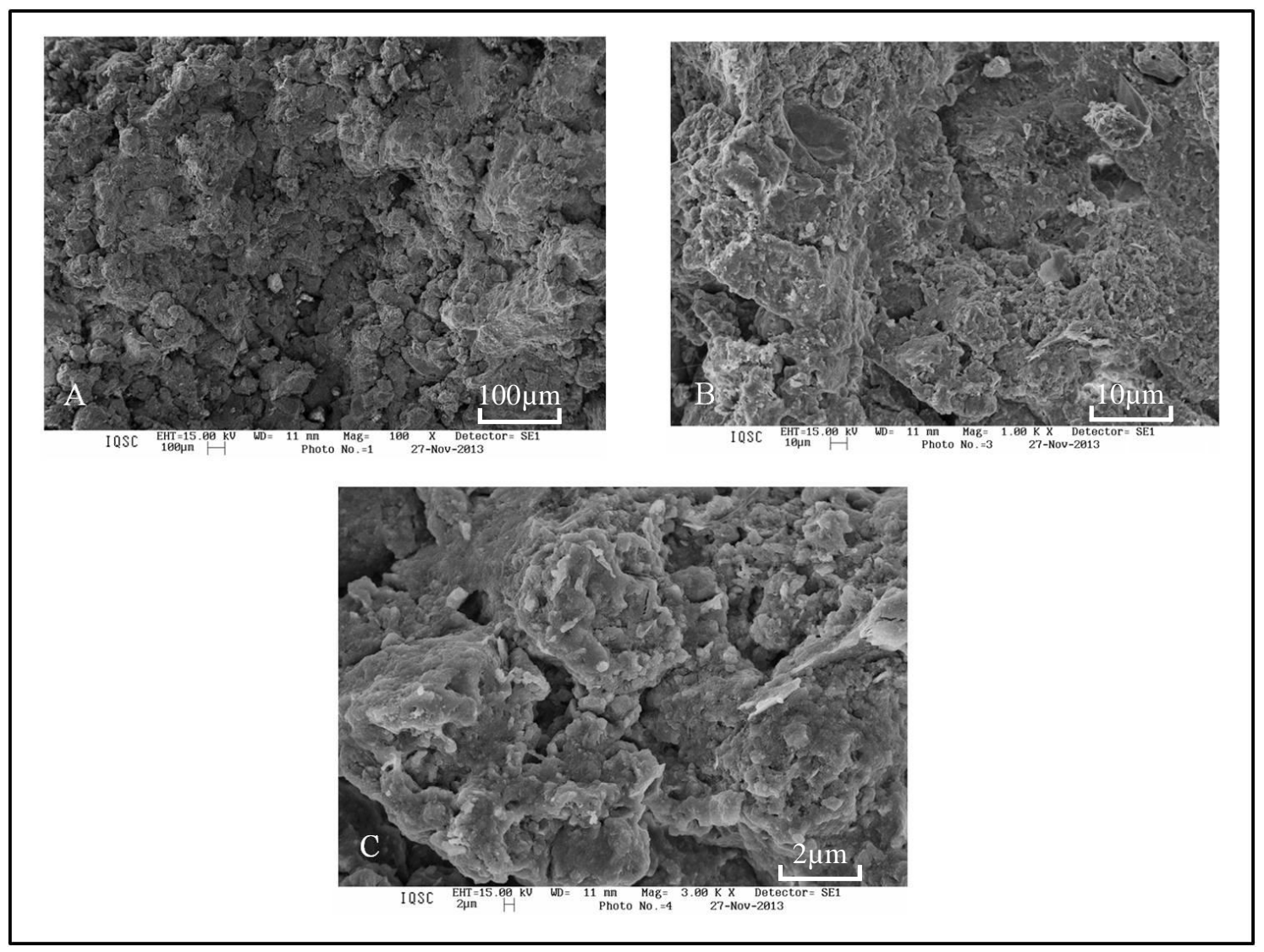

Figura 62 - Amostra de solo laterítico (LAT T3): A) Ampliação de 100 vezes; B) Ampliação de 1000 vezes; C) Ampliação de 3000 vezes.

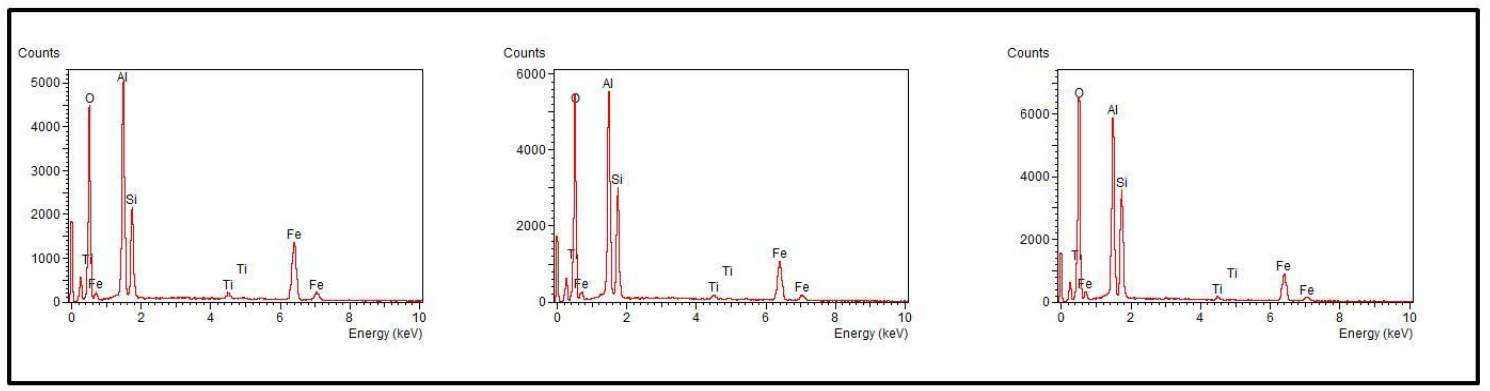

Figura 63 - Espectros EDS da amostra LAT T3 (obtido em três áreas distintas).

Tabela 22 - Média dos elementos obtida a partir dos EDS - LAT T3 (Figura 63).

\begin{tabular}{cc}
\hline Elementos & Quantidade (\%) \\
\hline $\mathbf{O}$ & 53,59 \\
\hline $\mathbf{A l}$ & 18,86 \\
\hline $\mathbf{F e}$ & 15,11 \\
\hline $\mathbf{S i}$ & 11,57 \\
\hline $\mathbf{T i}$ & 0,86 \\
\hline Total & $\mathbf{9 9 , 9 9}$ \\
\hline
\end{tabular}


A partir da Figura 62 é possível observar certa homogeneidade nesta amostra, com presença de vazios e algumas estruturas granulares menores (Figura 62C), que podem representar tanto a presença de quartzo como concreções lateríticas. Comparando-se com a Figura 64 (NOGAMI; VILLIBOR, 1995), é possível verificar a semelhança entre a amostra LAT T3 e a estrutura de Latossolo Roxo (atual Nitossolo) e Vermelho-amarelo (a e b, respectivamente).
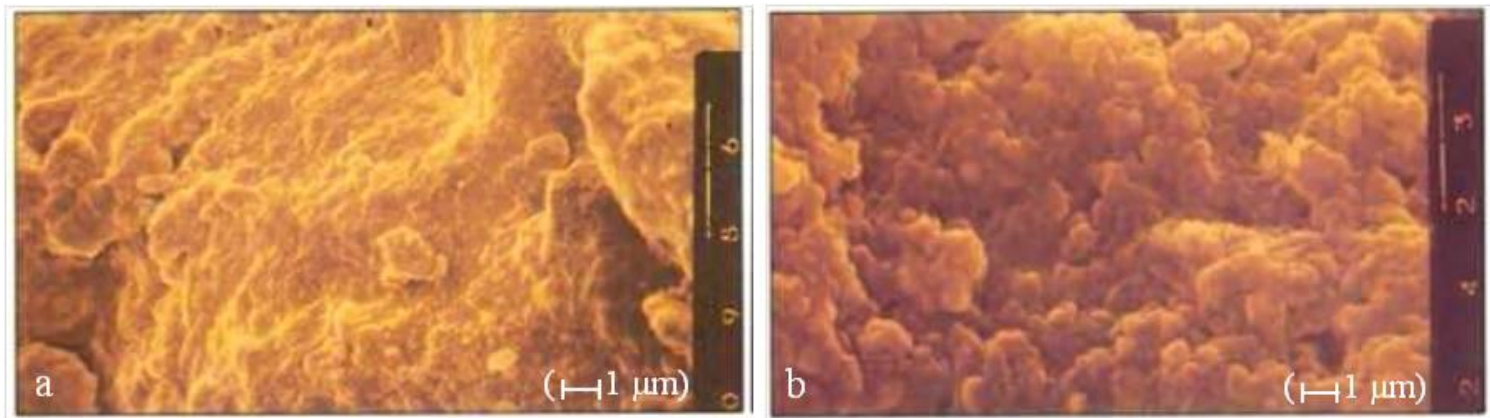

Figura 64 - a) Latossolo Roxo (terra roxa), argiloso; b) Latossolo Vermelho-amarelo, argiloso. (Adaptado de NOGAMI e VILLIBOR, 1995).

A partir dos dados da Figura 63 e Tabela 22 verifica-se que esta amostra possui óxidos de alumínio, silício (quartzo), titânio e ferro. Estes elementos se referem à presença de óxidos de ferro e alumínio, que, além de conferirem a coloração avermelhada desta amostra, apontam para o grau de alteração elevado e laterização deste solo, e ao quartzo. Segundo Nogami e Villibor (1995), em geral os solos lateríticos apresentam o quartzo como um dos principais constituintes, sendo também possível verificar a ilmenita (óxido de ferro e titânio) e a magnetita (óxidos de ferro), mais presentes nos Latossolos Roxos (atuais Nitossolos).

Os autores supracitados ainda afirmam que esse tipo de solo pode apresentar concreções lateríticas, compostas de óxidos hidratados de ferro e alumínio, as quais podem estar ligadas com magnetita, ilmenita, hematita e quartzo. Estas concreções podem não ser totalmente distinguíveis dos torrões de argila; apresentam diversidade de comportamentos, como adsorção de água, massa específica real maior que a do quartzo, da ordem de 3 a 5 g. $\mathrm{cm}^{-3}$, e resistência menor que este elemento, a qual faz com que estas concreções se desagreguem sem maiores dificuldades, utilizando-se martelo, por exemplo. A Figura 65 apresenta em campo um exemplo de visualização desta característica. Apesar disso, este tipo de solo exibe maior resistência que os solos saprolíticos, apresentados nos tópicos seguintes. 


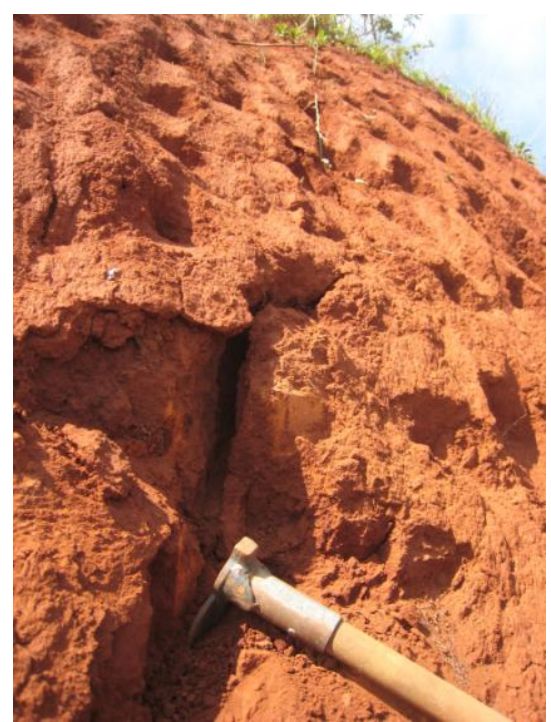

Figura 65 - Abertura realizada em fissura em uma encosta da voçoroca do Córrego do Cravo, Nazareno/MG, no Latossolo.

\section{SAP 1}

Os resultados de MEV e EDS da amostra SAP 1 são apresentados nas Figuras 66 e 67 e na Tabela 23. 


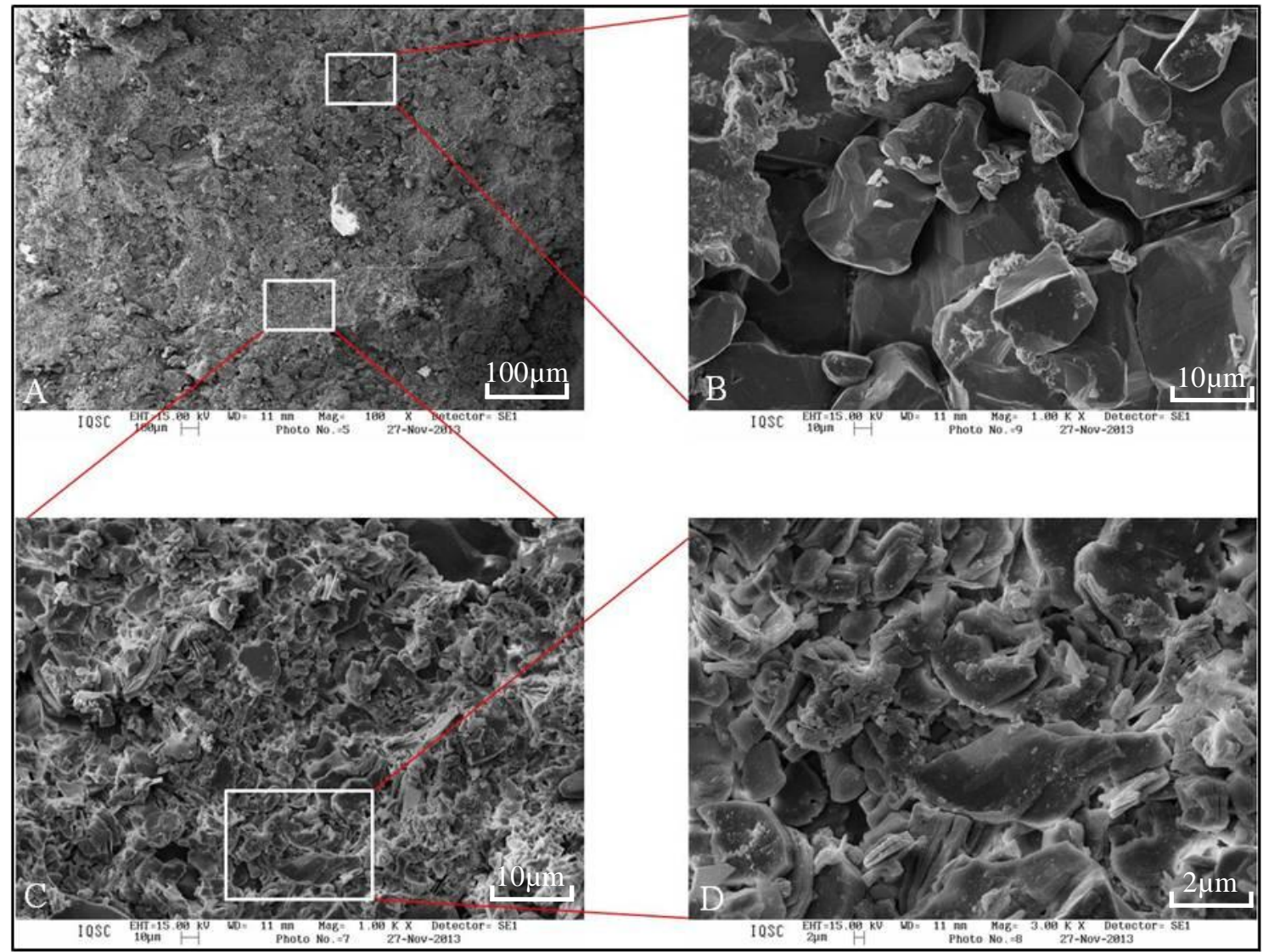

Figura 66 - Amostra de solo saprolítico (SAP 1): A) Ampliação de 100 vezes; B) Ampliação de 1000 vezes, região de cima; C) Ampliação de 1000 vezes, região de baixo; D) Ampliação de 3000 vezes.
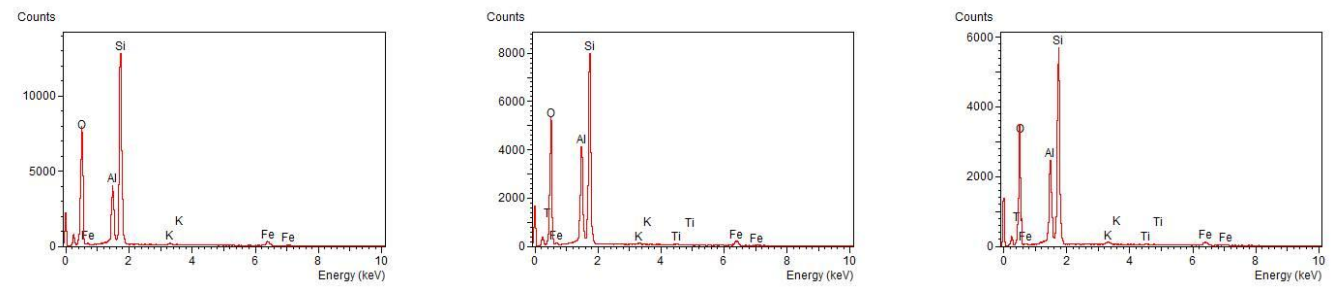

Figura 67 - Espectros EDS da amostra SAP 1 (obtido em três áreas distintas).

Tabela 23 - Média dos elementos obtida a partir dos EDS - SAP 1 (Figura 67).

\begin{tabular}{cc}
\hline Elementos & Quantidade (\%) \\
\hline $\mathbf{O}$ & 58,24 \\
\hline $\mathbf{S i}$ & 28,55 \\
\hline $\mathbf{A l}$ & 10,24 \\
\hline $\mathbf{F e}$ & 2,42 \\
\hline $\mathbf{K}$ & 0,37 \\
\hline $\mathbf{T i}$ & 0,17 \\
\hline Total & $\mathbf{1 0 0 , 0 0}$ \\
\hline
\end{tabular}


Na Figura 66, nota-se uma diferença entre as estruturas e arranjo das partículas neste tipo de solo. Verificou-se que as partículas se apresentaram de forma superposta, com alguns vazios, e com presença de materiais em estado de alteração ligados a elas (Figura 66B); já a Figura 66C exibiu estrutura com maior estado de alteração que a anteriormente citada, com maior aglomeração das partículas. Dessa forma, com a ampliação Figura 66C, observou-se a presença de estruturas placóides (micas) em processo de alteração.

A Figura 67 e a Tabela 23 mostram que as amostras LAT T3 (Figura 63 e Tabela 22) e SAP 1 possuem elementos em comum, porém, houve redução na quantidade de ferro na segunda em relação à primeira amostra. Houve também a detecção de potássio em baixas quantidades. De maneira geral, o solo SAP 1 é constituído, principalmente, por óxidos de silício e alumínio (Tabela 23).

Nogami e Villibor (1995) citam, para os solos saprolíticos, maior diversidade de elementos em relação aos lateríticos, sendo que os distintos graus de alteração acarretam no aparecimento de mais vazios; estes graus de alteração influenciam, também, na diversidade de comportamento verificada em materiais que apresentem os mesmos constituintes, como os feldspatos e as micas. Também através da Tabela 6 é possível confirmar que estes elementos estão coerentes com o que é esperado para a composição geoquímica das rochas da região.

\section{SAP 2}

Os resultados obtidos com a amostra SAP 2 são apresentados nas Figuras 68 e 69 e na Tabela 24. 


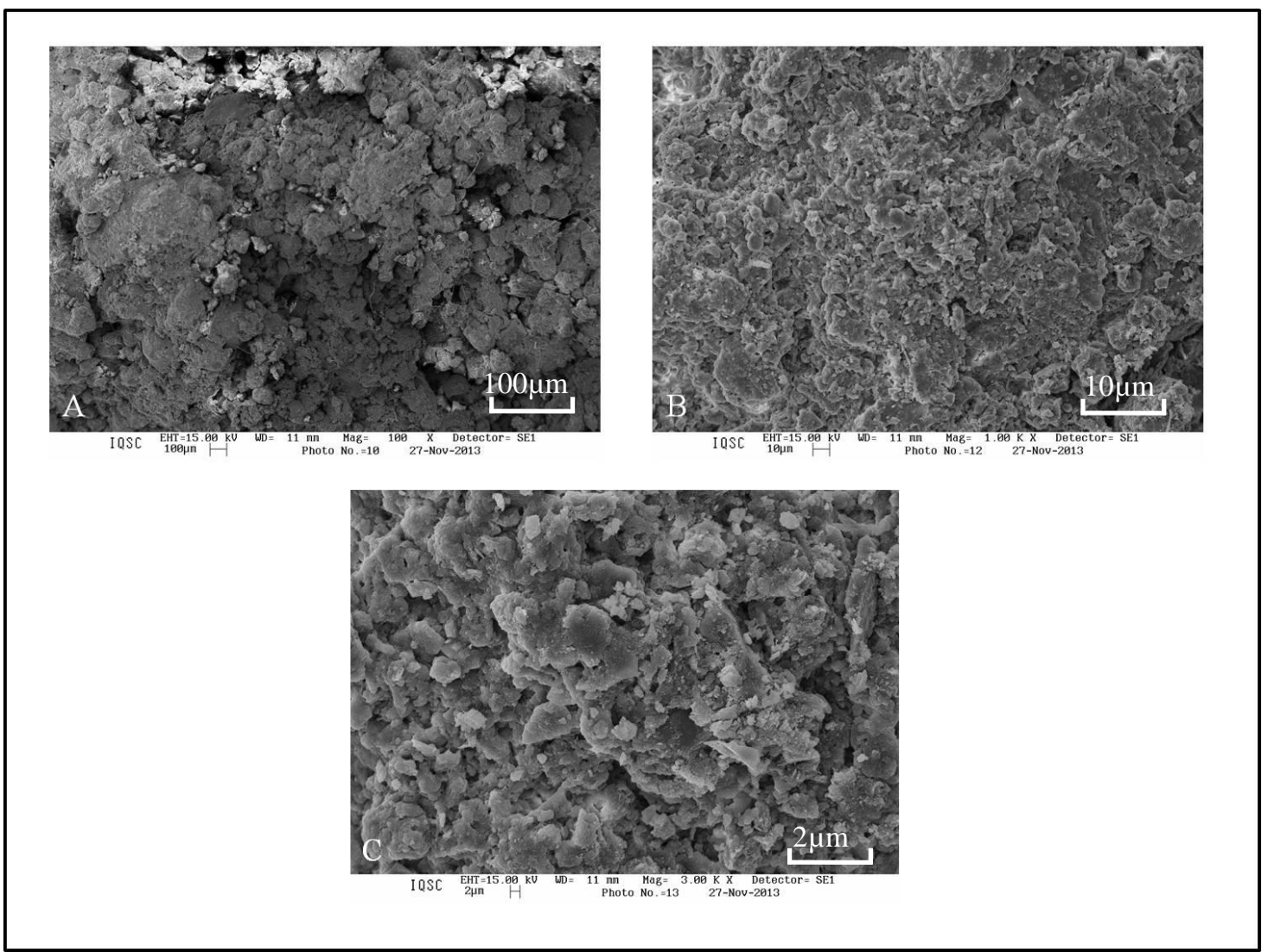

Figura 68 - Amostra de solo saprolítico (SAP 2): A) Ampliação de 100 vezes; B) Ampliação de 1000 vezes; C) Ampliação de 3000 vezes.

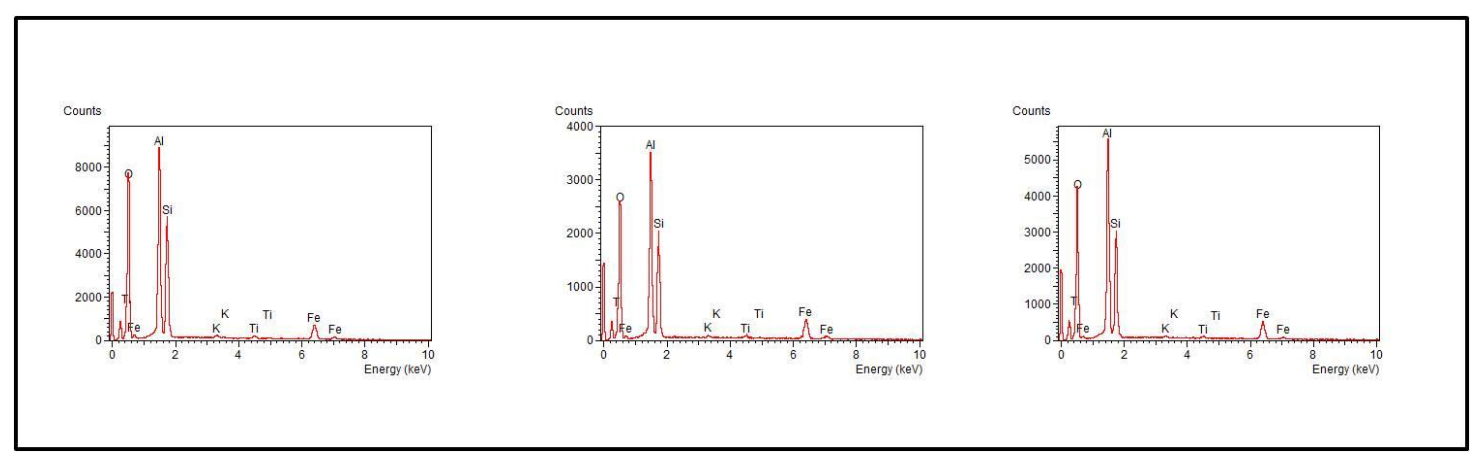

Figura 69 - Espectros EDS da amostra SAP 2 (obtido em três áreas distintas).

Tabela 24 - Média dos elementos obtida a partir dos EDS - SAP 2 (Figura 69).

\begin{tabular}{cc}
\hline Elementos & $\begin{array}{c}\text { Quantidade } \\
(\%)\end{array}$ \\
\hline $\mathbf{O}$ & 54,55 \\
\hline $\mathbf{A l}$ & 21,14 \\
\hline $\mathbf{S i}$ & 15,35 \\
\hline $\mathbf{F e}$ & 7,99 \\
\hline $\mathbf{T i}$ & 0,62 \\
\hline $\mathbf{K}$ & 0,35 \\
\hline Total & $\mathbf{1 0 0 , 0 0}$
\end{tabular}


Esta amostra, retirada de um local em que se percebeu a redução da espessura da camada de Latossolo, apresentou-se com muitas raízes e com estruturação muito semelhante à amostra LAT T3 (Figura 68A), ou seja, observa-se homogeneidade na estruturação, com elementos granulares e vazios. Ao se aumentar o detalhe (Figura 68B e C), os vazios e estruturas semelhantes a concreções presentes na amostra são destacados. Assim, em conjunto com as observações de campo, é possível considerar que este local se caracteriza por uma transição de características entre os Latossolos e os solos saprolíticos, sendo que estes últimos se encontram predominantes na área da voçoroca à medida que se caminha para jusante.

A Figura 69 e a Tabela 24 apontam, também, para esta transição, pois a quantidade de alumínio e ferro se pronuncia em relação à segunda amostra analisada. Porém, ainda permanecem os mesmos elementos e o potássio.

\section{SAP TX 3}

As Figuras 70 e 71 e a Tabela 25 apresentam os resultados da MEV e EDS para a amostra SAP TX 3, retirada em local com afloramento de material xistoso alterado. 


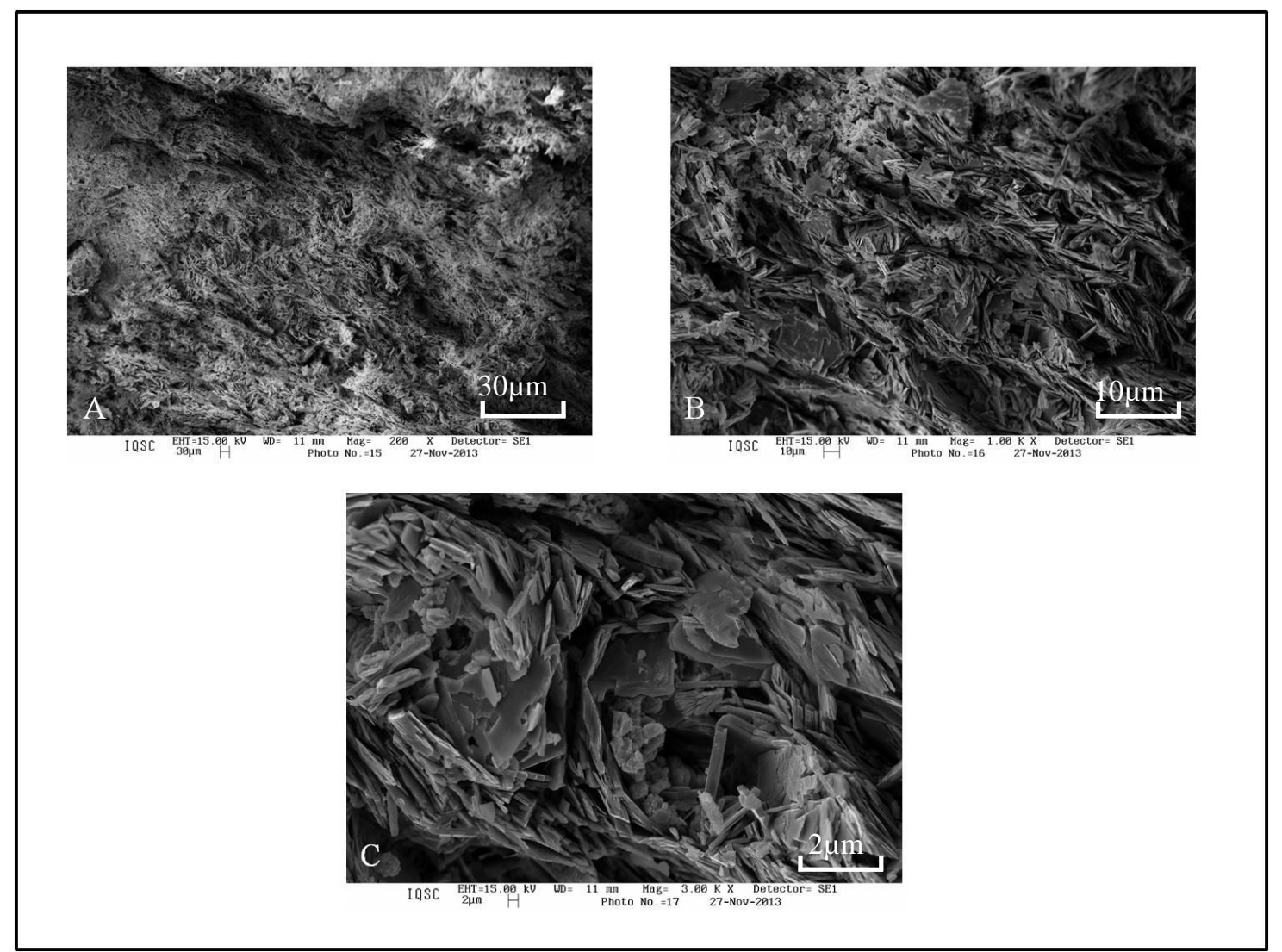

Figura 70 - Amostra de solo saprolítico (SAP TX 3): A) Ampliação de 200 vezes; B) Ampliação de 1000 vezes; C) Ampliação de 3000 vezes.
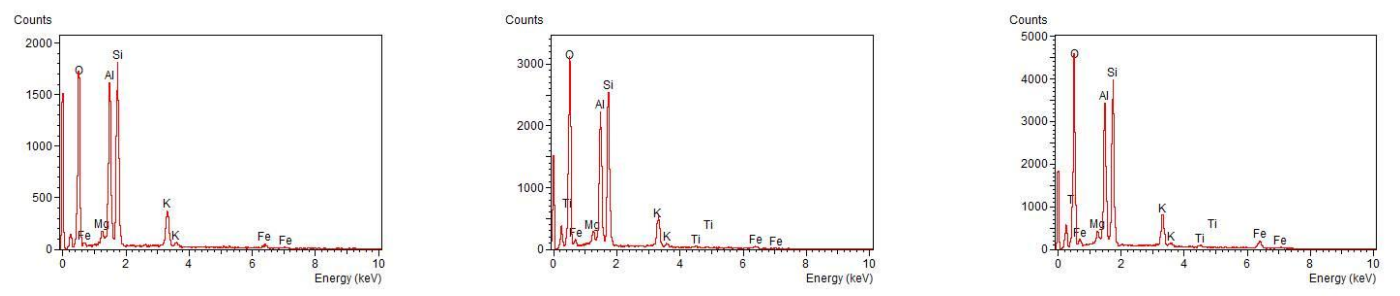

Figura 71 - Espectros EDS da amostra SAP TX 3 (obtido em três áreas distintas).

Tabela 25 - Média dos elementos obtida a partir dos EDS - SAP TX 3 (Figura 71).

\begin{tabular}{cc}
\hline Elementos & Quantidade (\%) \\
\hline $\mathbf{O}$ & 61,92 \\
\hline $\mathbf{S i}$ & 17,21 \\
\hline $\mathbf{A l}$ & 13,31 \\
\hline $\mathbf{K}$ & 4,66 \\
\hline $\mathbf{F e}$ & 1,63 \\
\hline $\mathbf{M g}$ & 1,02 \\
\hline $\mathbf{T i}$ & 0,24 \\
\hline Total & $\mathbf{1 0 0 , 0 0}$
\end{tabular}


A Figura 70 apresenta o detalhe da xistosidade verificada em campo (Figura 72). Ao se observar a amostra de campo na direção paralela à disposição dos minerais, verifica-se que esta é muito resistente; porém, ao se observar como na Figura 70, de forma perpendicular a esta disposição, verifica-se a fragilidade nas quebras das placas.

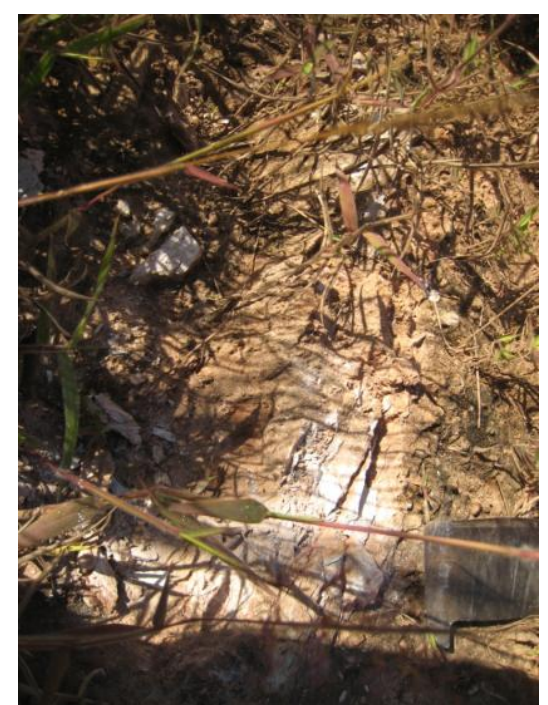

Figura 72 - Afloramento de talco-xisto em solo saprolítico, voçoroca do Córrego do Cravo, Nazareno/MG.

Os resultados apresentados pela Figura 71 e pela Tabela 25 exibem a semelhança de elementos que compõem este solo saprolítico e as outras amostras. Observa-se que a quantidade de potássio se elevou, a de ferro decaiu e, ainda, nota-se a presença de magnésio que ainda não havia sido detectado. Tal composição é coerente com o tipo de rocha que originou esse solo.

\section{SAP P 6, SAP P 7 e SAP P 8}

Os resultados destas três análises serão apresentados em conjunto, devido à similaridade e proximidade em campo, para avaliação entre si. As Figuras 73, 74 e 75 exibem os resultados das microfotografias. 


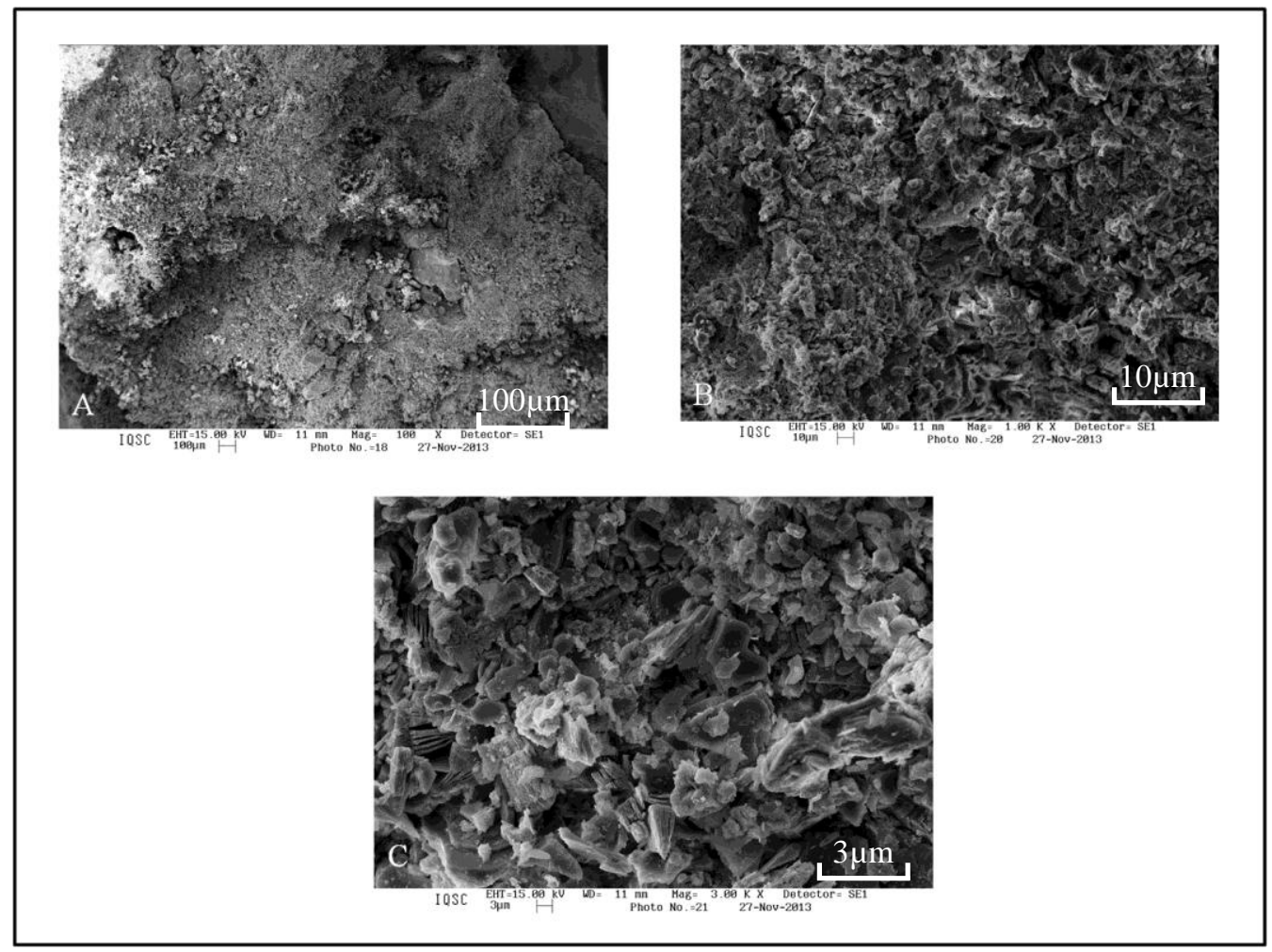

Figura 73 - Amostra de solo saprolítico (SAP P 6): A) Ampliação de 100 vezes; B) Ampliação de 1000 vezes; C) Ampliação de 3000 vezes.

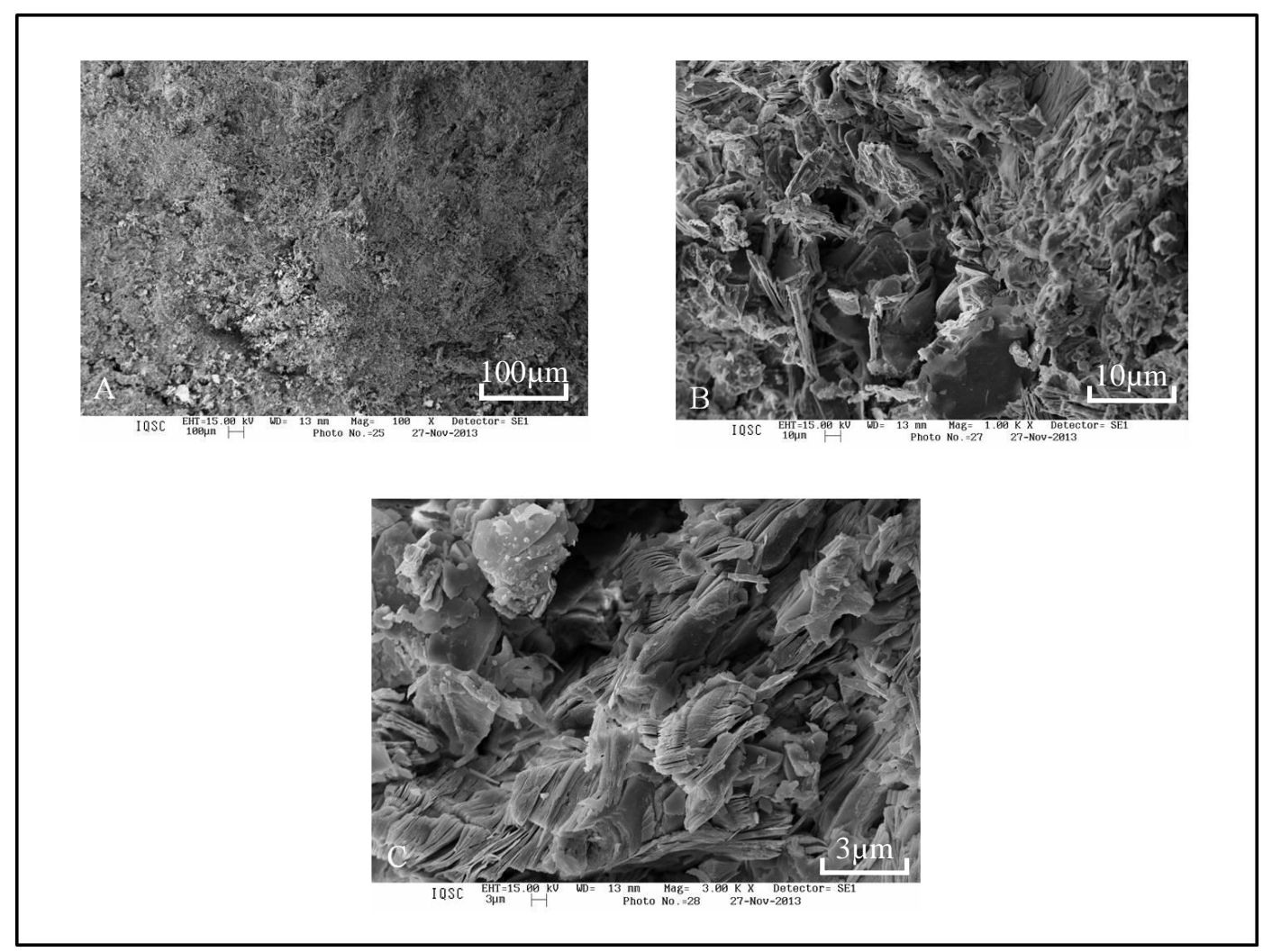

Figura 74 - Amostra de solo saprolítico (SAP P 7): A) Ampliação de 100 vezes; B) Ampliação de 1000 vezes; C) Ampliação de 3000 vezes. 


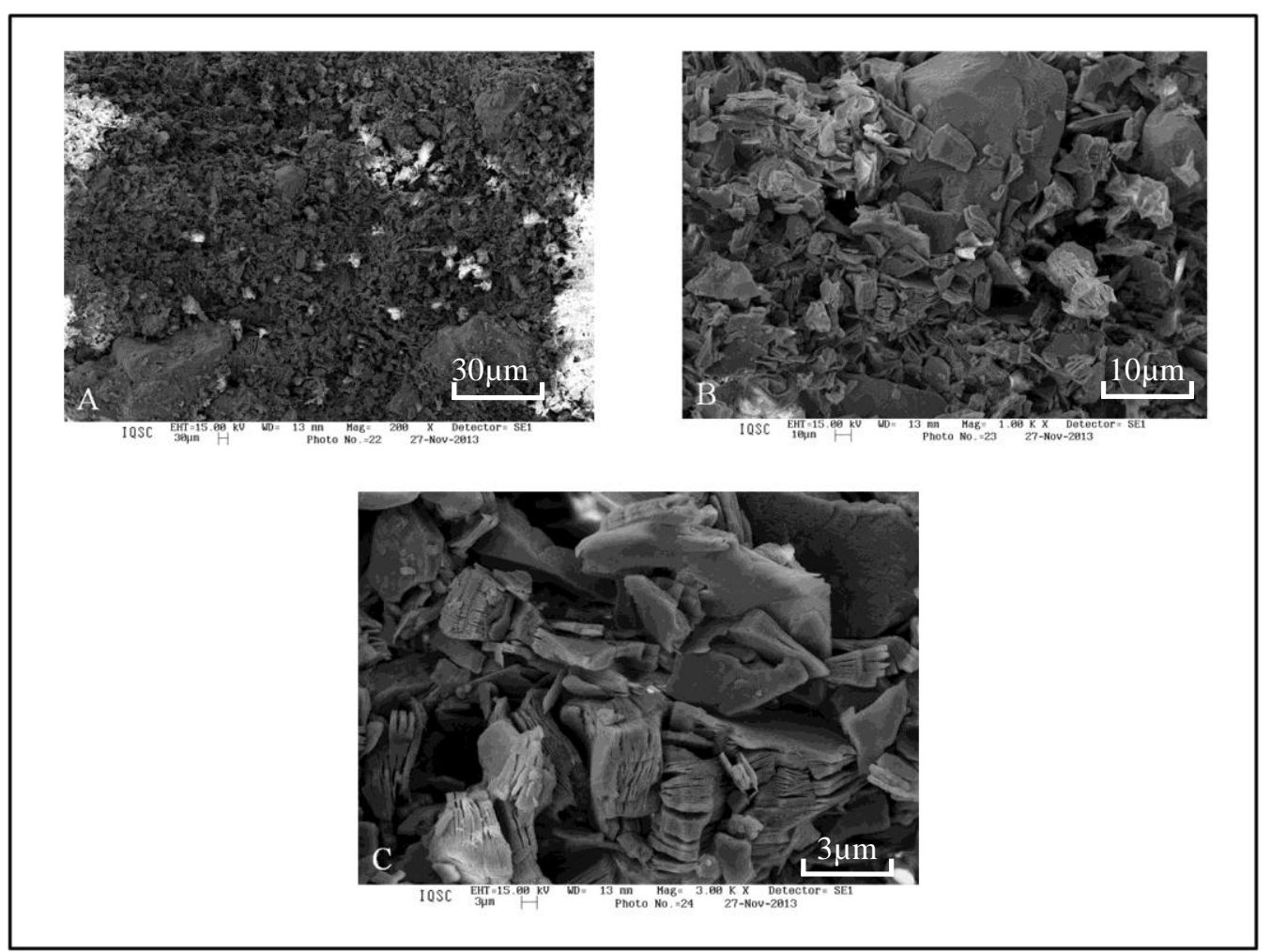

Figura 75 - Amostra de solo saprolítico (SAP P 8): A) Ampliação de 200 vezes; B) Ampliação de 1000 vezes; C) Ampliação de 3000 vezes.

É possível observar nas Figuras 73, 74 e 75 a existência de estruturas semelhantes entre si, porém, com certa variação entre elas. A Figura 73 apresenta a presença marcante de minerais placóides (micas) em relação às outras duas, sendo que, segundo Nogami e Villibor (1995) (Figura 76), solos que apresentam este mineral em predominância, quando passam pelo processo de compactação, podem se comportar com grande expansibilidade quando submersos, com elevada velocidade na ocorrência desse processo, e ao reduzir-se a umidade, apresentam pouca ou quase nula contração.

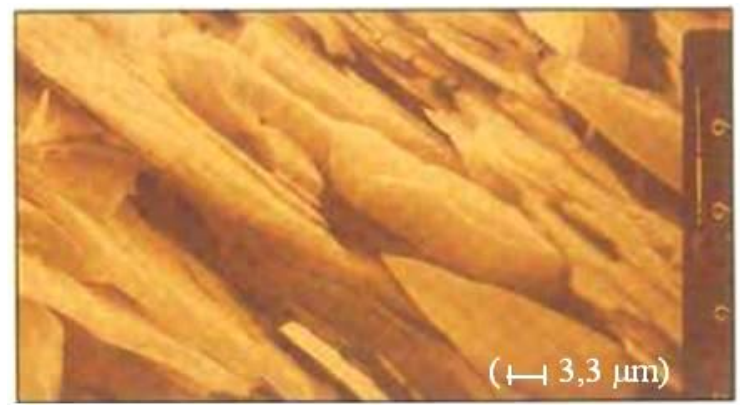

Figura 76 - Solo saprolítico de filito, com macrocristais de sericita (Adaptada de NOGAMI e VILLIBOR, 1995). 
As Figuras 74 e 75 exibem preponderância de minerais em formatos sanfonados, prismáticos, em relação à primeira, ainda com a presença de minerais placóides (micas). Estes minerais sanfonados são as caulinitas, comumente advindas de alteração dos feldspatos, e segundo Nogami e Villibor (1995) (Figura 77), à medida que estes minerais se associam com outros, como haloisitas e micas, torna-se complicada a compreensão de seu comportamento; porém, em geral, quando estão presentes na fração silte do solo podem apresentar comportamento diferenciado do quartzo, acrescentando certa coesão e expansão (similar às micas), originando índice de plasticidade diferente de zero. Como na Figura 77, é possível que este solo seja produto de intemperismo de micaxistos, pois esta região também apresenta este tipo de rocha, como apresentado no Capítulo 4.

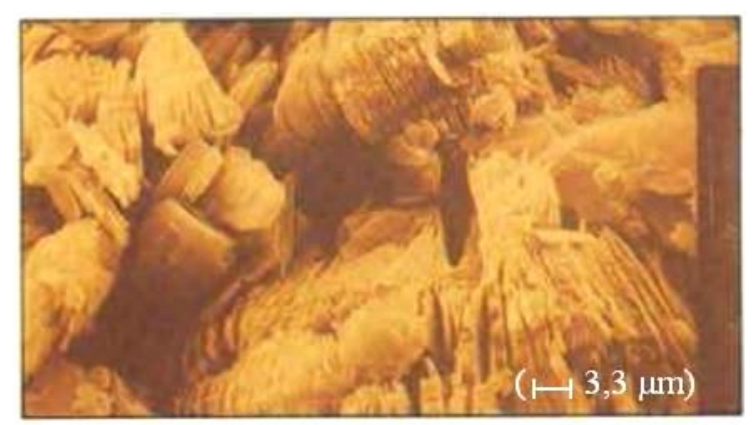

Figura 77 - Solo saprolítico de micaxisto, com macrocristais de caulinita (Adaptada de NOGAMI e VILLIBOR, 1995).

Os resultados dos espectros EDS e das porcentagens de elementos presentes nas amostras são apresentados nas Figuras 78, 79 e 80 e nas Tabelas 26, 27 e 28.
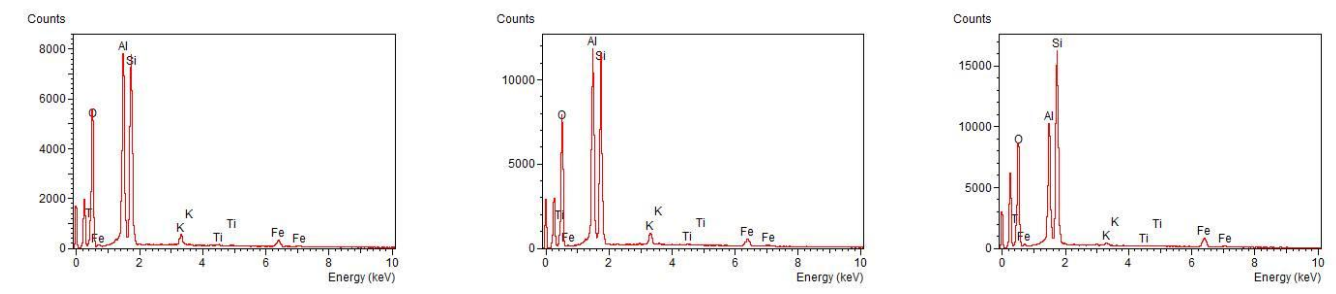

Figura 78 - Espectros EDS da amostra SAP P 6. 


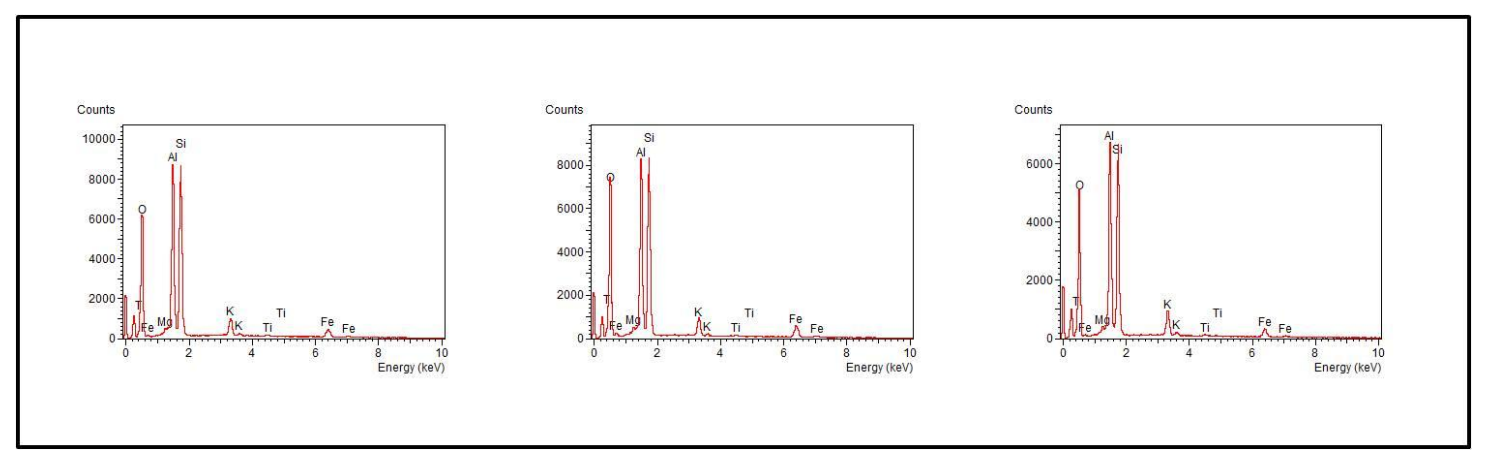

Figura 79 - Espectros EDS da amostra SAP P 7.
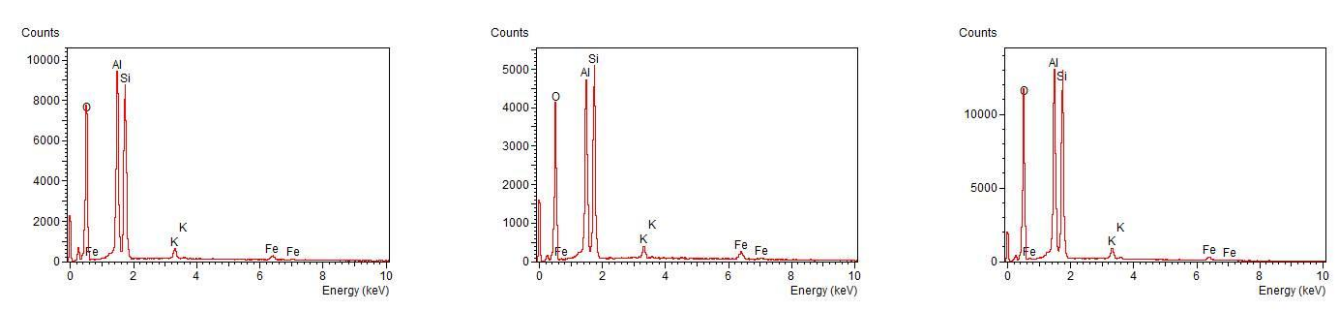

Figura 80 - Espectros EDS da amostra SAP P 8.

Tabela 26 - Média dos elementos obtida a partir dos EDS - SAP P 6.

\begin{tabular}{cc}
\hline Elementos & Quantidade (\%) \\
\hline $\mathbf{O}$ & 50,25 \\
\hline $\mathbf{S i}$ & 26,28 \\
\hline $\mathbf{A l}$ & 18,02 \\
\hline $\mathbf{F e}$ & 3,86 \\
\hline $\mathbf{K}$ & 1,39 \\
\hline $\mathbf{T i}$ & 0,20 \\
\hline Total & $\mathbf{1 0 0 , 0 0}$ \\
\hline
\end{tabular}

Tabela 27 - Média dos elementos obtida a partir dos EDS - SAP P 7.

\begin{tabular}{cc}
\hline Elementos & Quantidade (\%) \\
\hline $\mathbf{O}$ & 53,58 \\
\hline $\mathbf{S i}$ & 21,15 \\
\hline $\mathbf{A l}$ & 17,36 \\
\hline $\mathbf{K}$ & 3,31 \\
\hline $\mathbf{F e}$ & 4,01 \\
\hline $\mathbf{M g}$ & 0,27 \\
\hline $\mathbf{T i}$ & 0,32 \\
\hline Total & $\mathbf{1 0 0 , 0 0}$
\end{tabular}


Tabela 28 - Média dos elementos obtida a partir dos EDS - SAP P 8.

\begin{tabular}{cc}
\hline Elementos & Quantidade (\%) \\
\hline $\mathbf{O}$ & 57,14 \\
\hline $\mathbf{S i}$ & 21,46 \\
\hline $\mathbf{A l}$ & 17,54 \\
\hline $\mathbf{F e}$ & 2,10 \\
\hline $\mathbf{K}$ & 1,74 \\
\hline Total & $\mathbf{9 9 , 9 7}$
\end{tabular}

Estes resultados apontam que as amostras possuem composição muito semelhante, ou seja, óxidos de ferro e alumínio, quartzo e potássio predominantemente, e magnésio (SAP P 8) e titânio (SAP P 6 e 8) em menores proporções, e esta composição é associada às rochas presentes na região (Tabela 6).

Como citado anteriormente para solos tropicais (NOGAMI e VILLIBOR, 1995), mesmo apresentando composição geoquímica muito semelhante, devido ao intemperismo, eventos metamórficos e peculiaridades da região, como as zonas de cisalhamento, em uma área pequena como a da voçoroca do Córrego do Cravo, é possível verificar diferentes estruturas microscópicas que podem influenciar no comportamento em escala macroscópica dos solos. Sendo a permeabilidade dos Latossolos maior que a dos Cambissolos, por exemplo, pode-se correlacioná-la com o fato de que os primeiros apresentam concreções lateríticas e maior desenvolvimento, com comportamento de adsorção de água, e, mesmo que os segundos apresentem minerais que apontam para a alteração do material, como a caulinita, ainda possuem estruturas reliquiares das rochas, o que os tornam menos permeáveis. Já a erodibilidade, como outro exemplo, comporta-se de maneira inversa. Os Latossolos são menos erodíveis que os Cambissolos, também se podendo associar às mesmas justificativas: por preservarem ainda grande parte de material em alteração, os segundos não apresentam a coesão, resistência e uniformidade dos primeiros, sendo mais facilmente desagregáveis e carreados pela ação do escoamento. 


\subsection{Avaliação dos Dados Pluviométricos e da Bacia}

Os dados pluviométricos da Estação Bom Sucesso (MG) foram obtidos da Agência Nacional de Águas (ANA), diante da ausência de dados consistentes do próprio município de Nazareno. Mesmo advindo de um órgão nacional, comumente encontram-se falhas ou faltas nestes tipos de dados, sendo realizado o preenchimento destas falhas como descrito no Capítulo 5.4.

O Gráfico 11 foi elaborado para verificação do comportamento pluviométrico das precipitações máximas da região próxima a Nazareno; a escolha deste tipo de avaliação foi realizada com base na consideração de que os eventos chuvosos máximos devem ser utilizados para o planejamento de um projeto de drenagem. À medida que este não pode subestimar o volume e vazão de água que suportará, atenta-se para que se encontre valores mais próximos da realidade da área, com segurança suficiente; da mesma forma, o projeto não deve superestimar estes valores, evitando-se, assim, custos adicionais para implantação da obra projetada. 


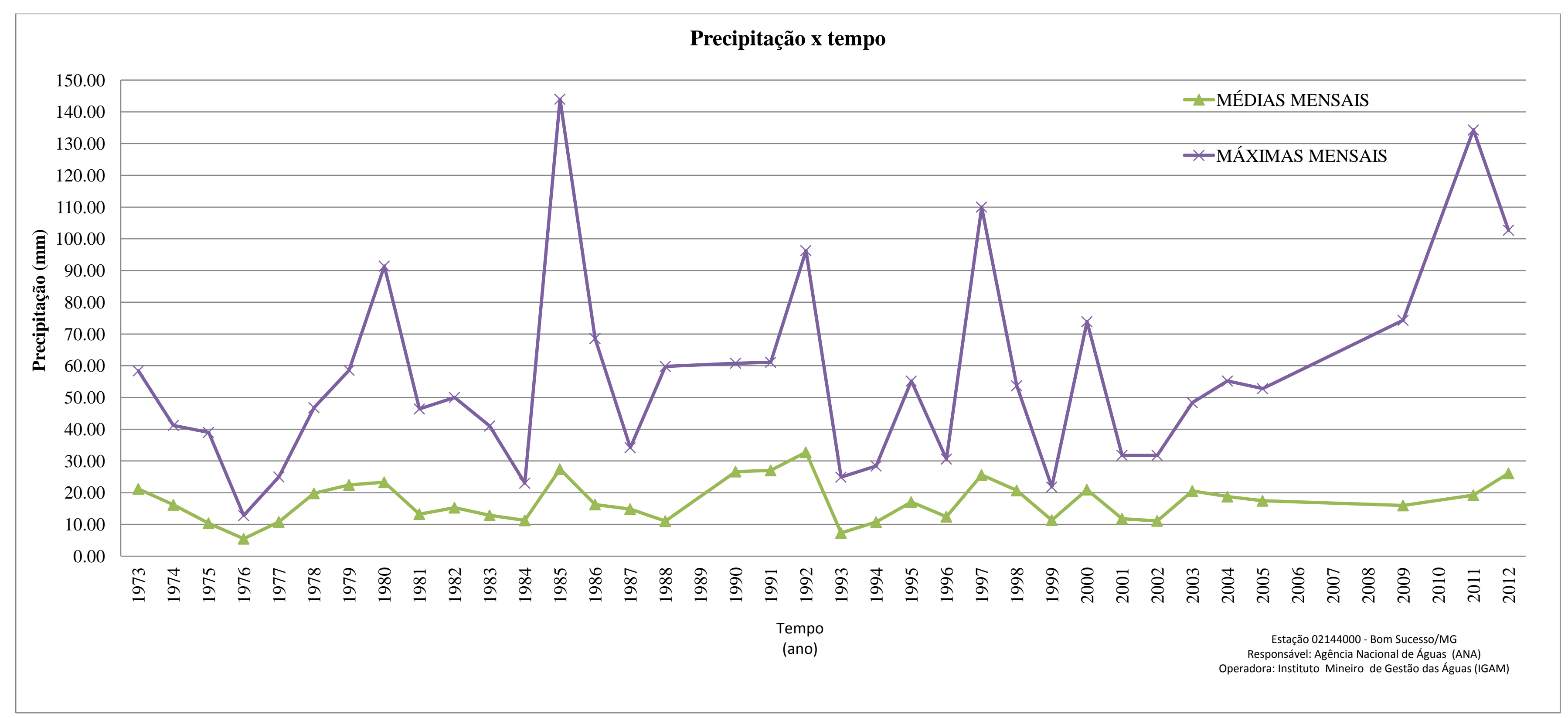

Gráfico 11 - Precipitações médias e máximas mensais (1973 a 2012) - Estação Bom Sucesso/MG. 
A partir dos resultados do Gráfico 11, observa-se que os três maiores valores encontrados entre as máximas foram 144,00 mm no ano de 1985, 110,00 mm para o ano de 1997, e 134,30 mm para 2011. Observa-se que, em geral, a precipitação se apresenta com caráter cíclico, sendo o comportamento típico de verão chuvoso (com os máximos valores entre novembro a janeiro) e inverno seco (de junho a agosto quase não se verificam precipitações), conforme observação realizada no Capítulo 4. Mesmo realizando-se estas observações, como se pode verificar no gráfico, o descarte de dados incompletos, como nos anos de 1989 e de 2006 a 2008, por exemplo, dificultou a precisão na utilização destes dados em outras considerações.

Sendo assim, desconsiderou-se a utilização dos dados obtidos com a Estação de Bom Sucesso para elaboração do hidrograma de chuvas para a área, buscando-se, em seguida, outras formas e ferramentas para realização de um estudo da vazão e do comportamento do escoamento superficial e subsuperficial aproximado para a região.

Após esta etapa, procedeu-se à utilização do software $A B C 6$, considerado acessível e pertinente a este estudo. Utilizando diretamente a equação intensidade, duração, frequência (IDF) de Barbacena/MG (representativa da região) presente no software, o período de retorno de 10 anos e a duração da chuva de 30 minutos, nas condições apresentadas no Capítulo 5.4, foi possível obter os resultados apresentados nas Figuras 81 e 82. O Nó 1 é considerado nos cálculos como a montante da bacia de contribuição, a Bacia 1 é a bacia de contribuição em si, e o Nó 2 é considerado o exutório da bacia de contribuição da voçoroca (Figura 49). 


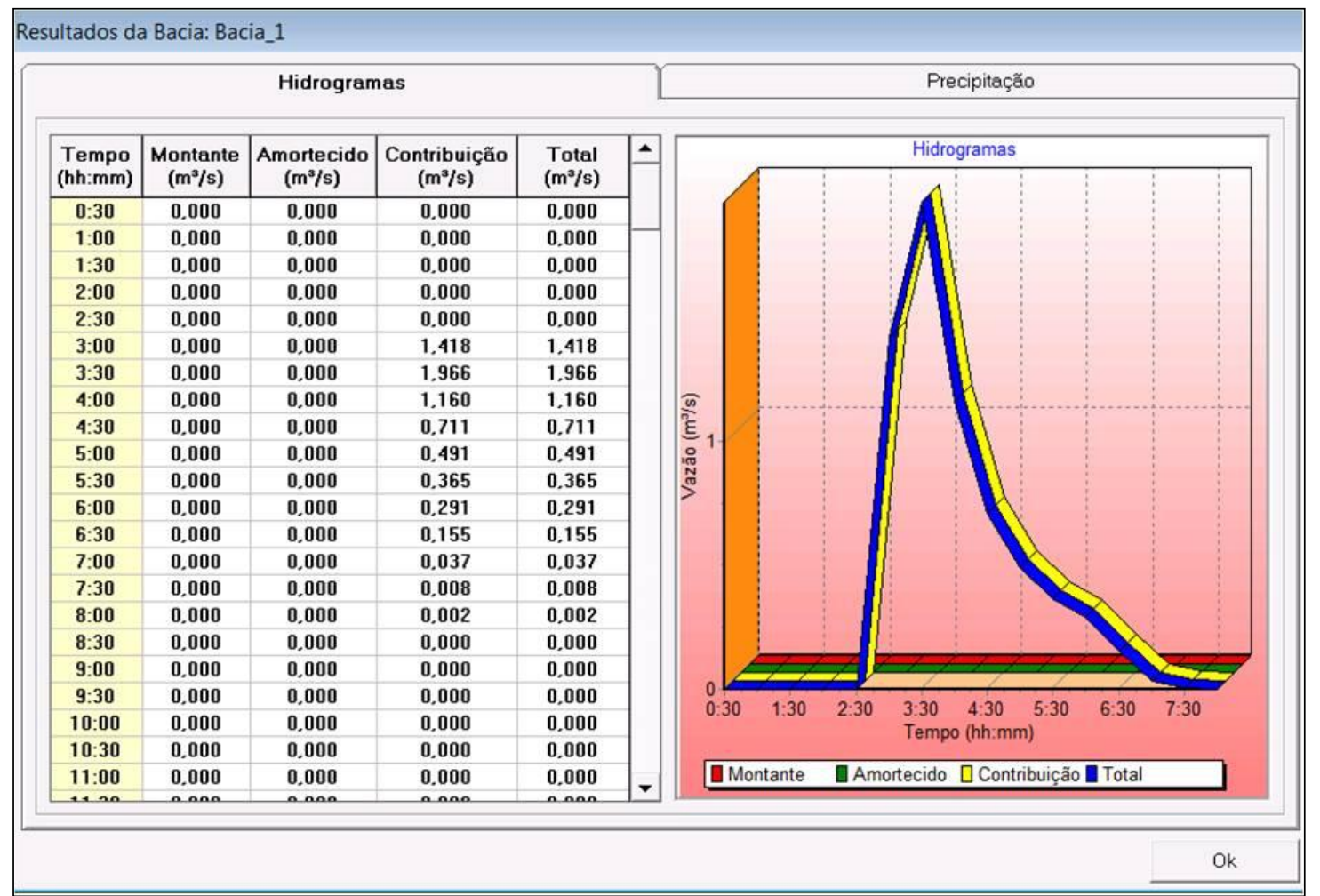

Figura 81 - Hidrogramas para Barbacena/MG, com período de retorno de 10 anos e duração de 30 minutos de chuva $-A B C 6$.

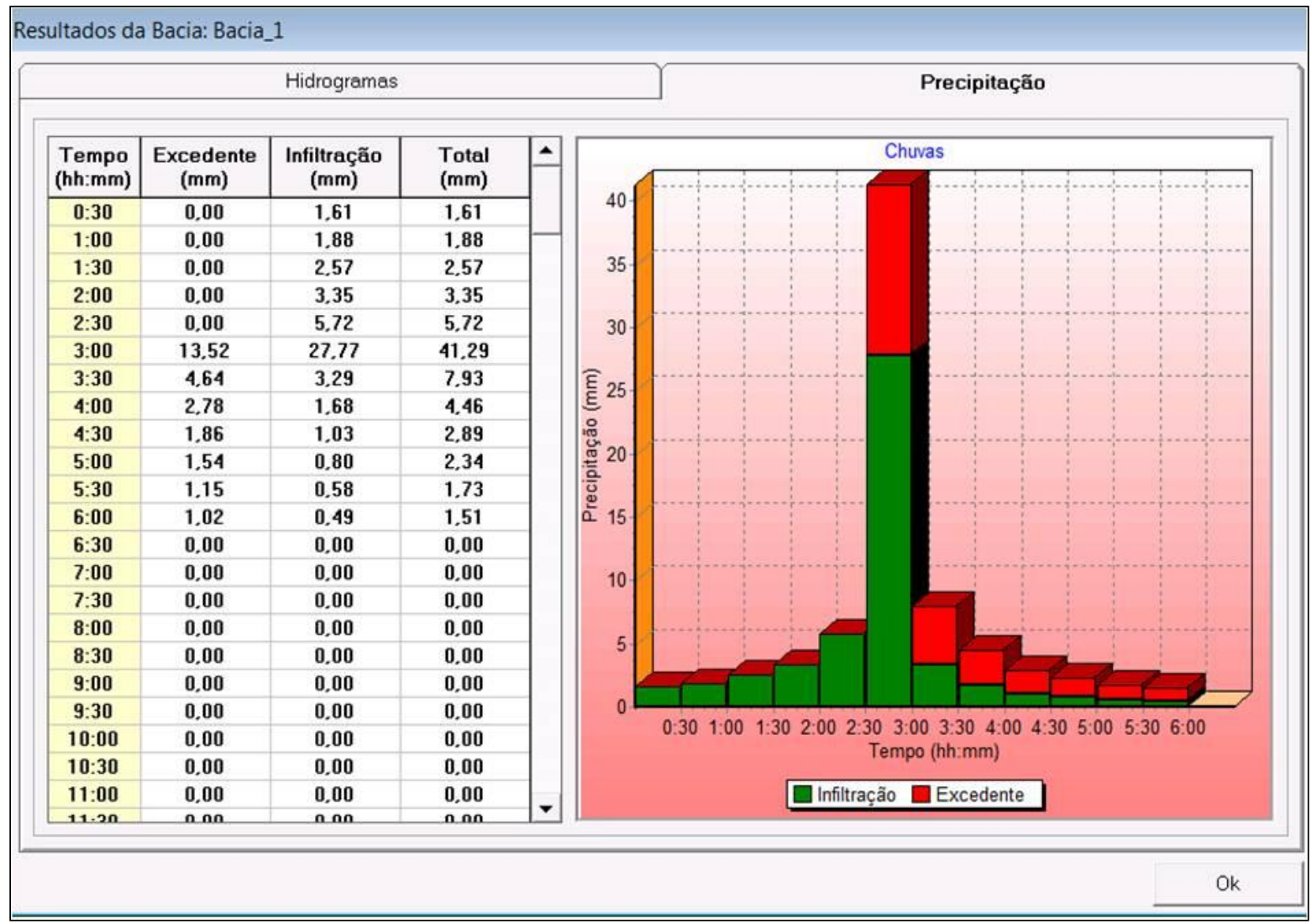

Figura 82 - Precipitação para Barbacena/MG, com período de retorno de 10 anos e duração de 30 minutos de chuva $-A B C 6$. 
A Figura 81 apresenta o comportamento da vazão na bacia de contribuição considerada, por um intervalo de 8 horas após o início da chuva. A vazão de pico encontrada para estas condições de período de retorno e duração da chuva foi de $1,966 \mathrm{~m}^{3} \cdot \mathrm{s}^{-1}$. Não são apresentados os hidrogramas de montante ou de amortecimento por não haver bacias à montante ou alguma estrutura de amortecimento na área considerada.

Em relação à Figura 82, verifica-se que, nas condições de tipo e uso do solo da bacia de contribuição considerada, até 2 horas e 30 minutos após o início da chuva toda a água precipitada praticamente é infiltrada, sendo que em 3 horas, do total precipitado de 41,29 mm, serão infiltrados $22,77 \mathrm{~mm}$ e $13,52 \mathrm{~mm}$ serão escoados efetivamente.

O hidrograma obtido para o Nó 2, apresentado na Figura 83, confirma que a vazão de pico que chegará ao exutório da bacia de contribuição é a mesma encontrada anteriormente; isto se deve ao fato de que não é considerada a existência de estruturas como a bacia de amortecimento ao longo da contribuição.

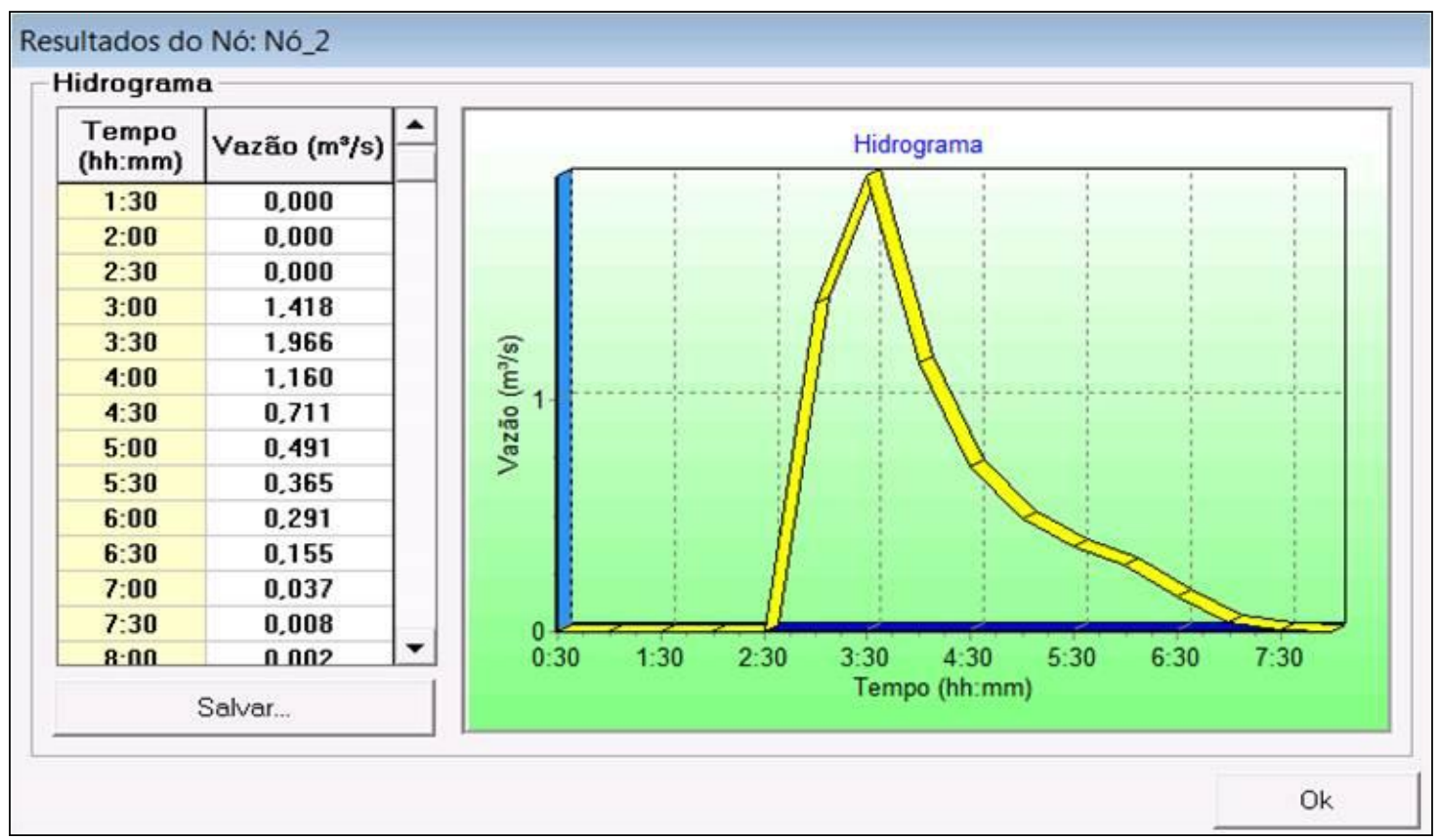

Figura 83 - Hidrograma encontrado para o nó 2 (exutório) da bacia de contribuição - $A B C 6$. 


\subsection{Concepção de Projeto de Drenagem - Propostas para a Voçoroca do Córrego do Cravo}

Após os estudos e ensaios realizados, foi possível depreender que esta região, em especial a voçoroca do Córrego do Cravo, apresenta como condicionantes naturais da área que a tornam susceptível ao aparecimento de erosões os tipos e características dos solos e a declividade, sendo que a intervenção humana no uso do solo pode ser considerada a deflagradora dos processos erosivos. Isso se deve ao fato de que, mesmo com a precipitação na região e com estes condicionantes naturais, outros locais em que não estão presentes estradas sem as devidas obras de drenagem ou atividades mineradoras, por exemplo, não apresentam a ocorrência de processos erosivos de tal porte como a voçoroca do Córrego do Cravo.

Diante disso, foram realizadas as propostas detalhadas a seguir como forma de direcionamento de futuros projetos de recuperação de áreas degradadas da região, tentando-se utilizar de viabilidade técnica e financeira, adequando-se às características físicas e aos condicionantes geológicos e geotécnicos da área.

\subsubsection{BACIA DE CONTRIBUIÇÃO - VOÇOROCA DO CÓRREGO DO CRAVO}

Avaliando-se a bacia de contribuição da voçoroca do Córrego do Cravo (Anexo 03), observa-se que o escoamento superficial necessita ser desviado dos locais próximos ao cafezal e das encostas da voçoroca. Isto se deve ao fato de que esta região apresenta inclinação muito acentuada e exposição do solo, principalmente de solo saprolítico (Cambissolo), e estes fatores atuam favorecendo a desagregação e o transporte das partículas pela força do escoamento superficial. Dessa forma, propõe-se a realização de uma trincheira de infiltração percorrendo a estrada de terra que limita o cafezal e a voçoroca e um canal de escoamento livre conectado a esta trincheira, sendo a transição realizada por uma soleira ou barragem de 
consolidação, localizada lateralmente à voçoroca, que possuirá a função de recolher o escoamento de montante da voçoroca e conduzi-lo à jusante. A visualização desta proposta pode ser realizada através da Figura 84. 


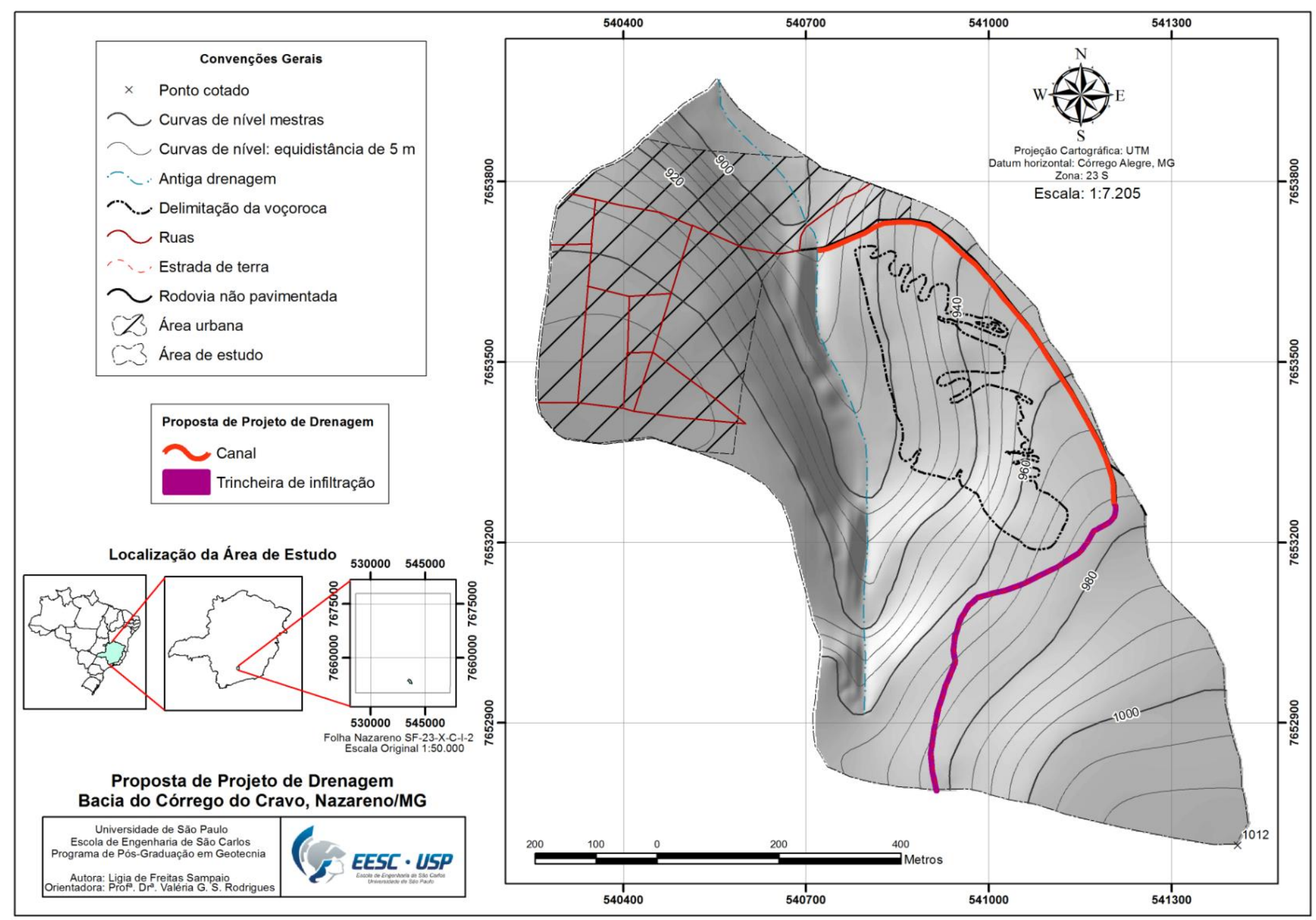

Figura 84 - Concepção de proposta de drenagem para a bacia de contribuição da voçoroca do Córrego do Cravo, Nazareno/MG. 
As trincheiras de infiltração, como uma das propostas de técnica compensatória linear de drenagem para a área de contribuição da voçoroca do Córrego do Cravo, em Nazareno (MG), podem ser realizadas em quaisquer locais que se encontrem em condições semelhantes à citada nesta pesquisa. Podem ser utilizadas tanto para drenagem de locais que se encontram em andamento de construção, como em canteiros de obras e loteamentos, como naqueles em que já se encontram atividades estabelecidas, como em ruas, passeios, jardins, estacionamentos, centros esportivos, dentre outros. Além de apresentarem simplicidade na construção e no desempenho, são excelentes no aproveitamento do espaço (BAPTISTA; NASCIMENTO; BARRAUD, 2011).

Esta técnica foi escolhida devido a sua função principal na infiltração da água da área à montante da bacia de contribuição, pois esta região apresenta uma estrada de terra que concentra o escoamento superficial que atinge diretamente a voçoroca (Figuras 85 e 86), e, em contrapartida, possui uma camada espessa de Latossolo, que pode contribuir com a infiltração devido à característica de maior resistência, permeabilidade e matéria orgânica em relação aos saprolitos (Cambissolos), reduzindo-se assim o aporte e velocidade da água a jusante.

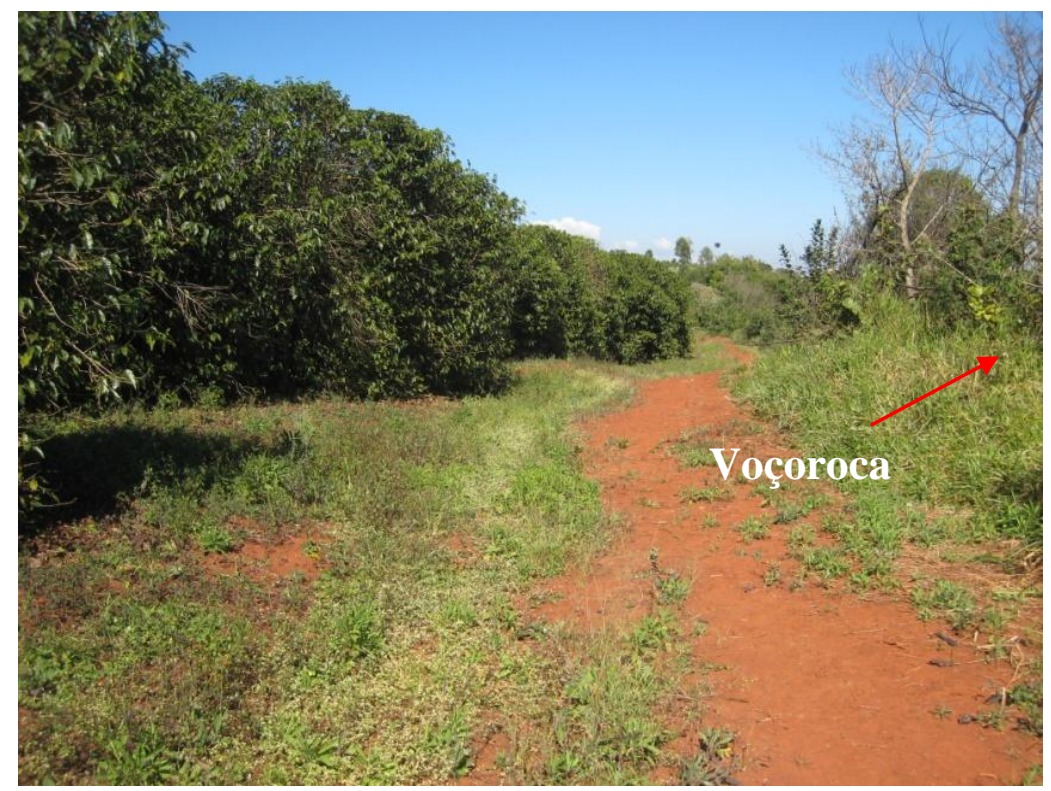

Figura 85- Estrada de terra margeando o cafezal próximo à voçoroca do Córrego do Cravo, em Nazareno/MG. 


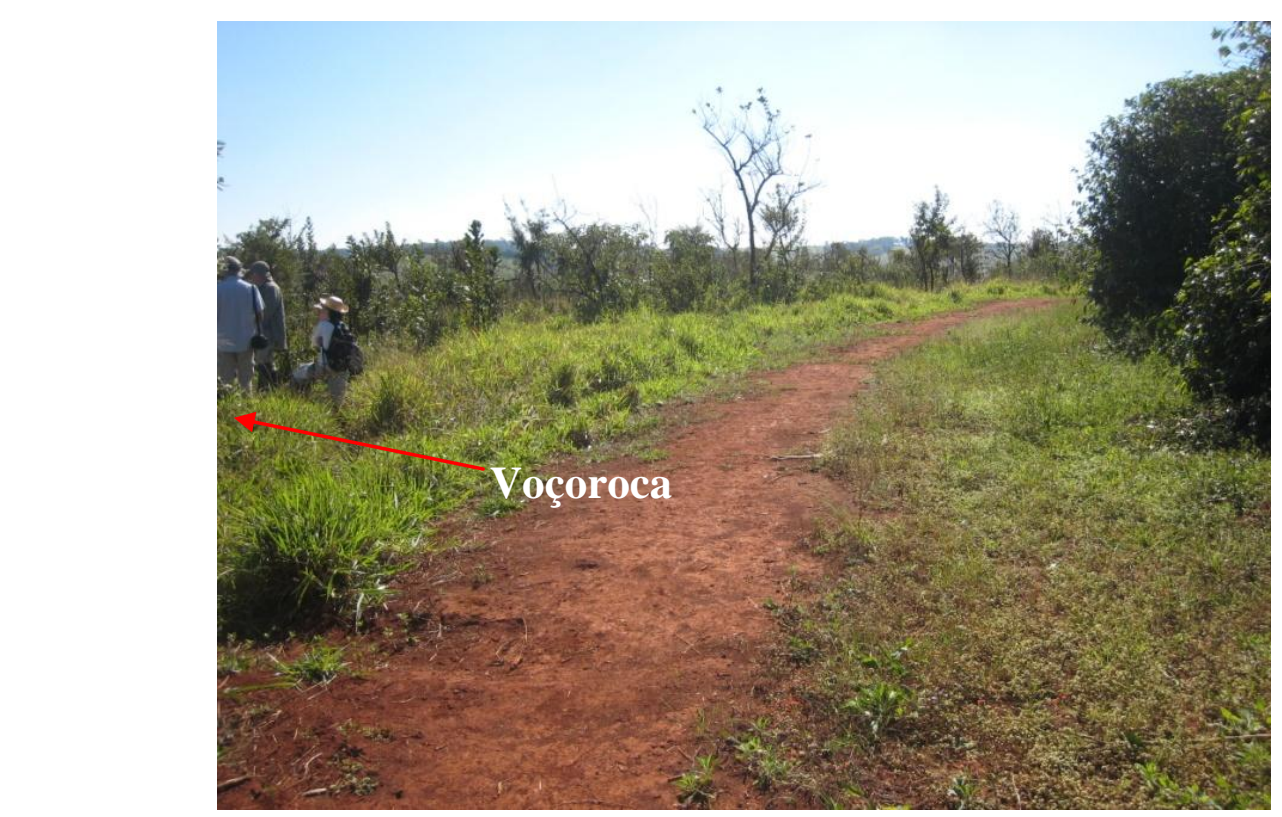

Figura 86 - Detalhe do limite entre a estrada de terra do cafezal e a voçoroca do Córrego do Cravo, em Nazareno/MG.

A trincheira de infiltração é fundamental para auxiliar na estabilização dos processos erosivos na área. Como observado no Tópico 6.2.5, o solo saprolítico (Cambissolo) apresenta elevados teores de areia fina e silte, que são facilmente carreados pela água. Além disso, as declividades elevadas do terreno favorecem o aumento na velocidade do escoamento superficial, que agrava o quadro do transporte das partículas mencionadas acima, e dificulta a permanência de água no terreno, reduzindo a capacidade de desenvolvimento de qualquer vegetação que se encontre próxima, mesmo em locais onde se encontre maior permeabilidade e matéria orgânica, como no caso do Latossolo.

A Tabela 29 exibe os quesitos necessários para utilização das trincheiras segundo Baptista, Nascimento e Barraud (2011), em confronto com o que é encontrado para a área de estudo. 
Tabela 29 - Quesitos para análise da viabilidade de realização de trincheiras de infiltração utilizados de Baptista, Nascimento e Barraud (2011).

\begin{tabular}{|c|c|}
\hline Baptista, Nascimento e Barraud (2011) & Voçoroca do Córrego do Cravo \\
\hline $\begin{array}{l}\text { Solo com permeabilidade suficiente: } \\
\text { acima de } 10^{-7} \mathrm{~m} \cdot \mathrm{s}^{-1} \text {. }\end{array}$ & $\begin{array}{l}\text { Solo saprolítico, menos permeável, } \\
\text { apresenta condutividade hidráulica } \\
\text { da ordem de } 1,68.10^{-6} \mathrm{~m} \cdot \mathrm{s}^{-1} \text {. }\end{array}$ \\
\hline $\begin{array}{l}\text { Solo suporte da trincheira: boa estabilidade, } \\
\text { isto é, não apresentar comportamentos de } \\
\text { dissolução, não apresentar argilominerais de } \\
\text { características expansivas (expansão ou } \\
\text { contração), etc. }\end{array}$ & $\begin{array}{l}\text { Tanto Latossolos } \\
\text { Cambissolos podem ser solos } \\
\text { suportes para as trincheiras, pois } \\
\text { apresentam predominantemente } \\
\text { caulinita, segundo Oliveira et al. } \\
\text { (2013); porém, a proteção com } \\
\text { geotêxtil ou geomanta é importante } \\
\text { para que se consiga maior } \\
\text { estabilidade. }\end{array}$ \\
\hline $\begin{array}{l}\text { Nível máximo de lençol freático: necessita } \\
\text { estar } 1,0 \mathrm{~m} \text { de distância da base das trincheiras }\end{array}$ & $\begin{array}{l}\text { Nível d'água aflorante na parte } \\
\text { interna da voçoroca, entre } 10 \text { e } 20 \\
\text { metros de profundidade em relação } \\
\text { ao topo. Condição adequada. }\end{array}$ \\
\hline $\begin{array}{l}\text { Zona de infiltração regularizada: verificar se } \\
\text { a área se encontra em zona de recarga ou } \\
\text { captação de água potável. }\end{array}$ & $\begin{array}{l}\text { Não é área regularizada de recarga } \\
\text { ou captação de água potável. } \\
\text { Condição adequada. }\end{array}$ \\
\hline $\begin{array}{l}\text { Atividades poluentes próximas: verificar se a } \\
\text { área foi ou é alvo de atividades poluentes ou } \\
\text { escoamento de contaminação potencial. }\end{array}$ & $\begin{array}{l}\text { Não é alvo de atividades poluentes. } \\
\text { Condição adequada. }\end{array}$ \\
\hline $\begin{array}{l}\text { Materiais finos: verificar se existem materiais } \\
\text { muito finos que poderiam causar a colmatação } \\
\text { precoce da obra. }\end{array}$ & $\begin{array}{l}\text { Atenção para a presença de silte e } \\
\text { areia fina nos Latossolos e } \\
\text { Cambissolos; utilização de geotêxtil } \\
\text { ou geomanta auxilia neste quesito. }\end{array}$ \\
\hline
\end{tabular}

Diante desse quadro, compreende-se que este tipo de estrutura é viável para um projeto de drenagem e infiltração das águas superficiais na região, desde que se mantenha a atenção devida para possíveis alterações das condições locais ou para quesitos como o dos materiais finos.

Os condicionantes e dimensionamentos de um projeto para implantação de trincheiras de infiltração mencionados a seguir foram retirados de Baptista, Nascimento e Barraud (2011), seguindo as adaptações necessárias para a área de estudo desta pesquisa.

A Figura 87 apresenta um esquema de como poderiam ser construídas as trincheiras de infiltração na área de estudo. As trincheiras de escoamento direto necessitariam de envolvimento com geotêxtil ou geomanta, para proteger o interior de excessivo carreamento 
de materiais de granulometria mais fina e de material de preenchimento de característica mais grosseira, como pedras de mão ou pedregulhos para compreender a infiltração e transporte vagaroso da água coletada. Além disso, considera-se necessário seu recobrimento, ou com grama ou com alguma tela ou grade, para evitar o rolamento do material de preenchimento e conferir maior resistência no caso de algum veículo passar por ela; entretanto, destaca-se a recomendação de se realizar alguma estrutura como cercas, para proteção da obra.

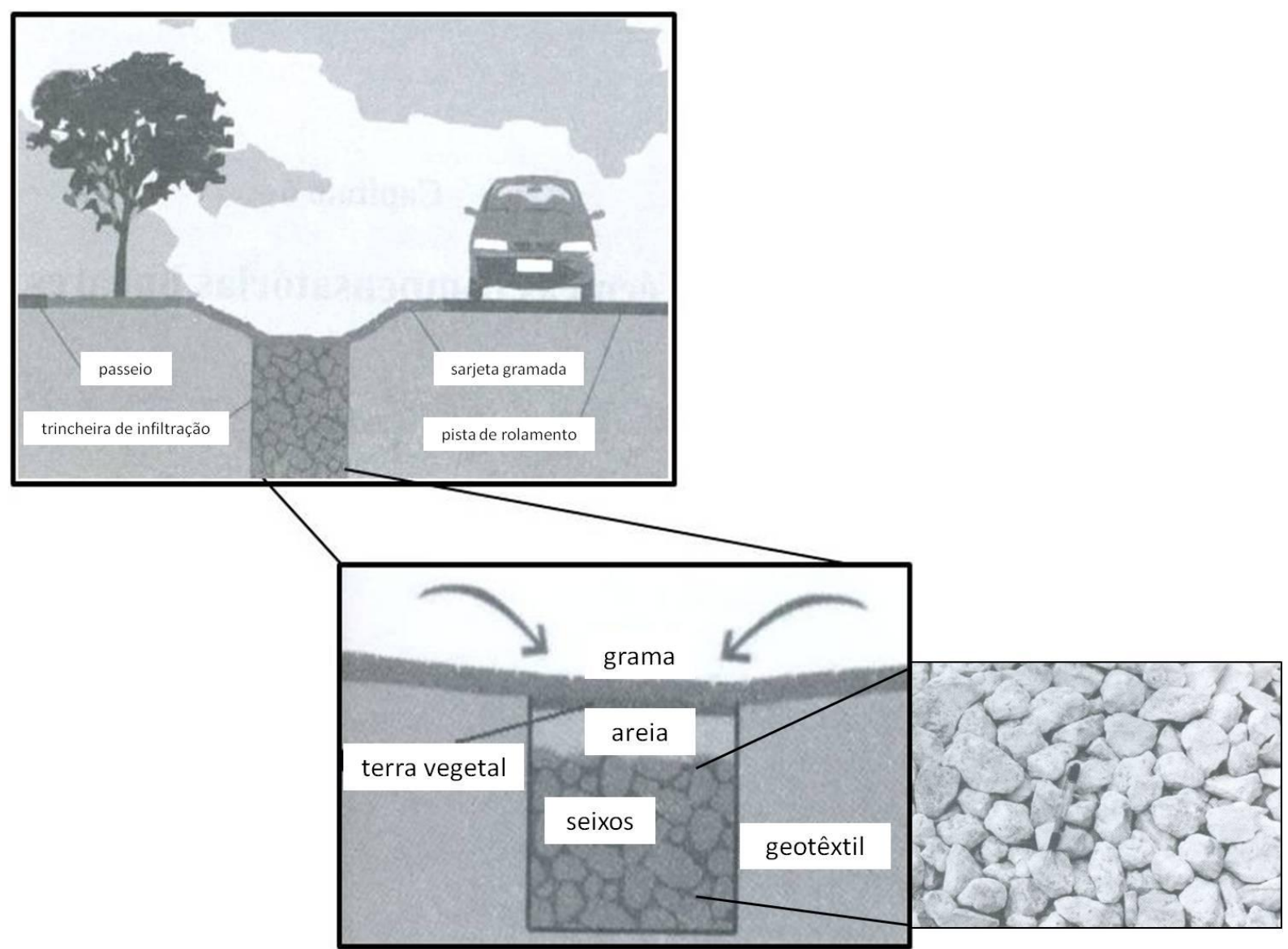

Figura 87 - Trincheira de infiltração com escoamento direto (Modificada de BAPTISTA; NASCIMENTO; BARRAUD, 2011).

A bacia de contribuição da voçoroca do Córrego do Cravo apresenta muitos locais onde as trincheiras teriam que ser implantadas perpendicularmente às curvas de nível, como visto no Anexo 03; ainda, devido as elevadas declividades $\left(0,1000\right.$ a $\left.0,2000 \mathrm{~m} . \mathrm{m}^{-1}\right)$ e a presença de materiais siltosos e finos, o aproveitamento do volume da trincheira pode ser prejudicado e/ou a colmatação pode ocorrer entre o material drenante, reduzindo sua eficiência. Uma metodologia para cálculo do volume de armazenamento avaliado segundo a inclinação do terreno é apresentada na Tabela 30. 
Tabela 30 - Capacidade de armazenamento em função da inclinação da trincheira para um volume geométrico $\mathrm{S}_{\mathrm{g}}=\mathrm{npLl}$ (Modificada de BAPTISTA; ALMEIDA; BARRAUD, 2011).

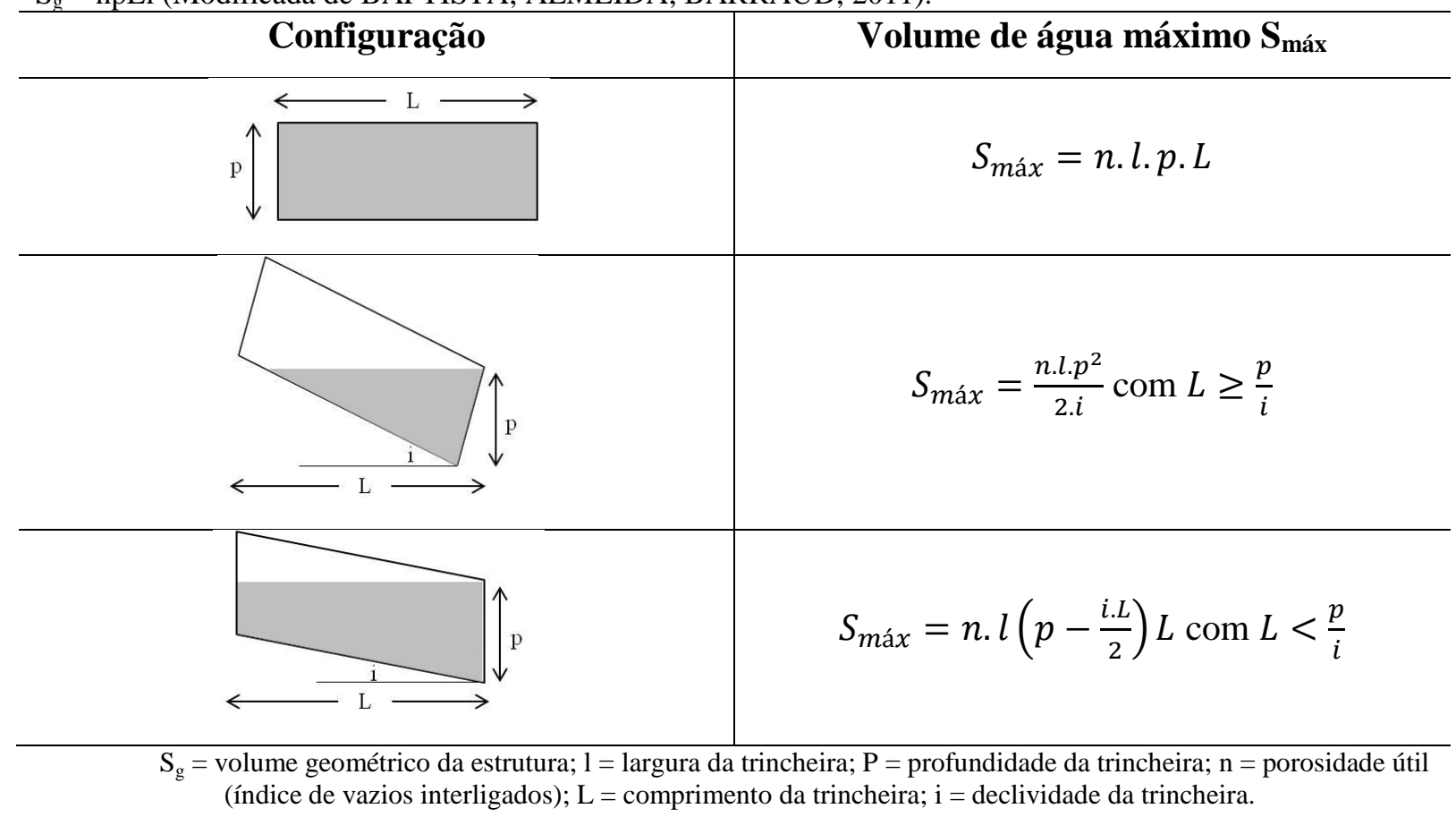

Neste caso, podem ser utilizadas barreiras ou divisórias internas às trincheiras para aumentar a capacidade de abrigar maior volume, com compartimentos conectados para drenar a vazão de saída (Figura 88); podem-se utilizar materiais como feixes de bambu tratado, como forma de adaptação para estas barreiras, tomando-se o devido cuidado para sua adequada instalação. Também podem ser utilizados, de forma alternada nestes compartimentos, cestos para recolhimento de resíduos e sedimentos, com funcionamento semelhante a peneiras, para facilitar a manutenção e limpeza das trincheiras (Figuras 89). 


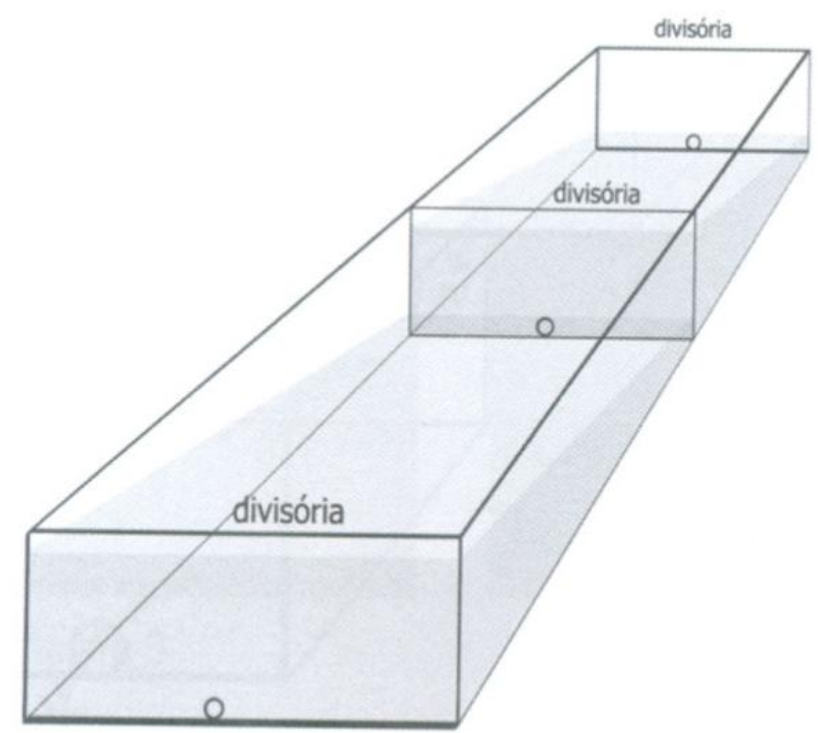

Figura 88 - Esquema de uma trincheira em declive dotada de divisórias (AZZOUT et al., 1994 apud BAPTISTA; ALMEIDA; BARRAUD, 2011).

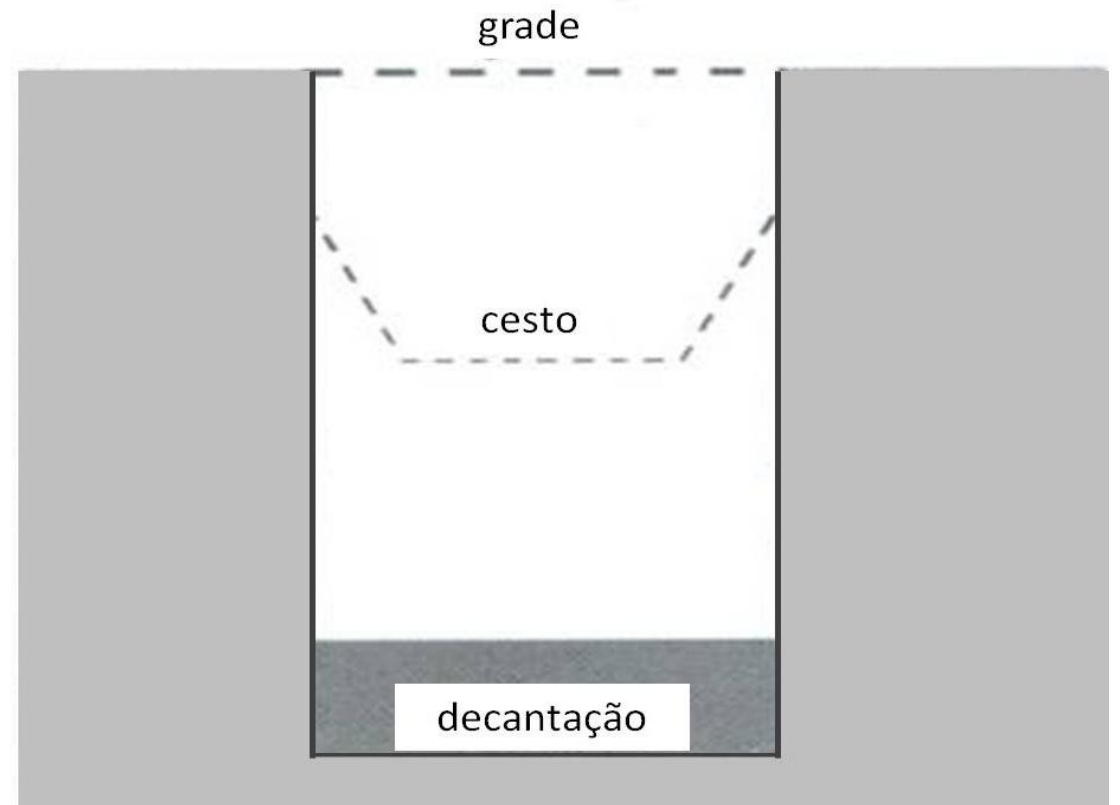

Figura 89 - Exemplo de proteção da trincheira: cesto para retirada de material (Modificada de AZZOUT et al., 1994 apud BAPTISTA; ALMEIDA; BARRAUD, 2011).

Em relação às vazões, pode-se utilizar a encontrada com o software $A B C 6$ como estudo preliminar para o dimensionamento hidráulico, sendo necessário realizar as adaptações adequadas no caso de se utilizarem as barreiras internas nas trincheiras. A Figura 90 também pode ser utilizada para auxiliar a encontrar uma vazão correlacionada com coeficientes de segurança, de acordo com a situação da área de estudo. 


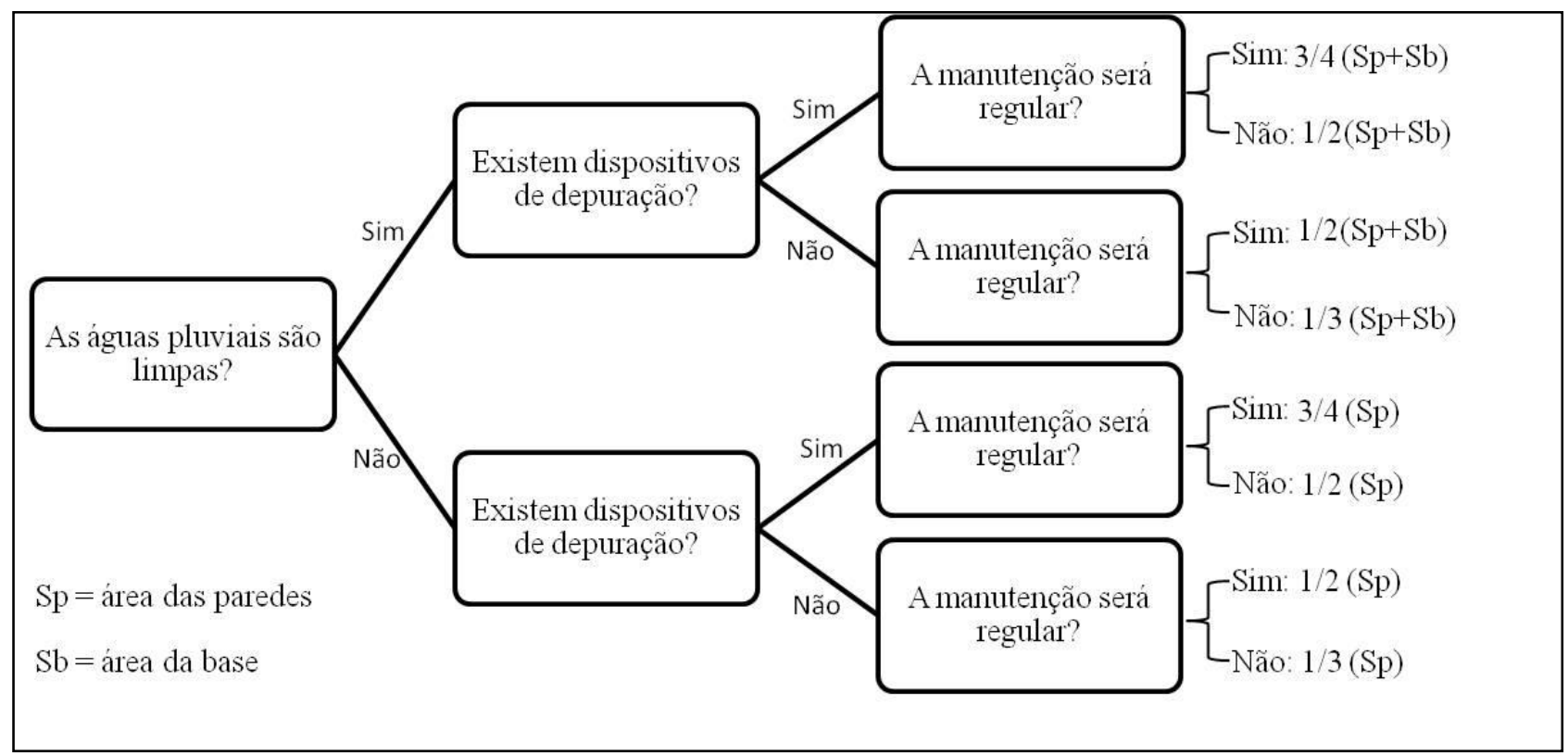

Figura 90 - Superfície de infiltração a ser considerada na determinação da vazão de saída no caso de uma trincheira (AZZOUT et al., 1994 apud BAPTISTA; ALMEIDA; BARRAUD, 2011).

Para o canal de escoamento superficial, a ferramenta utilizada para compreender quais são os fatores que interferem em sua eficiência e como seria possivelmente sua configuração, foi o software Canal, do Grupo de Pesquisa em Recursos Hídricos (GPRH), da Universidade Federal de Viçosa.

Utilizando-se o croqui da voçoroca (Anexo 03), foi possível, com a ferramenta Measure do ArcGIS ${ }^{\circledR}$, encontrar um comprimento de aproximadamente 800 metros para o caminho que o canal necessitaria percorrer. Em seguida, utilizou-se a vazão encontrada de $1,966 \mathrm{~m}^{3} \mathrm{~s}^{-1}$ (no software Canal este valor somente pode ser inserido até a segunda casa decimal) para o período de retorno de 10 anos com o software $A B C 6$ e as declividades de 0,1000 e 0,2000 m.m $\mathrm{m}^{-1}$, calculadas a partir das curvas de nível (Anexo 03), como diretrizes para simular as condições da área; realizou-se um estudo dos tipos e características de seções de canais que poderiam ser realizados na área, procurando-se manter a velocidade baixa e o regime subcrítico do escoamento superficial.

Em princípio, com o auxílio do software Canal, foram inseridos os parâmetros para estudo da conformação dos canais circulares que poderiam ser utilizados na voçoroca. Deixando-se como incógnita no software o coeficiente de rugosidade de Manning, utilizou-se, além das variáveis supracitadas, o diâmetro de 3,00 m para o canal e profundidade normal de 2,000 m, para observação inicial de como um canal com condições para construção na área se 
comportaria. Com as variações de declividade de $0,1000 \mathrm{~m} . \mathrm{m}^{-1}$ e $0,2000 \mathrm{~m} . \mathrm{m}^{-1}$, os resultados obtidos foram os apresentados nas Figuras 91 e 92.

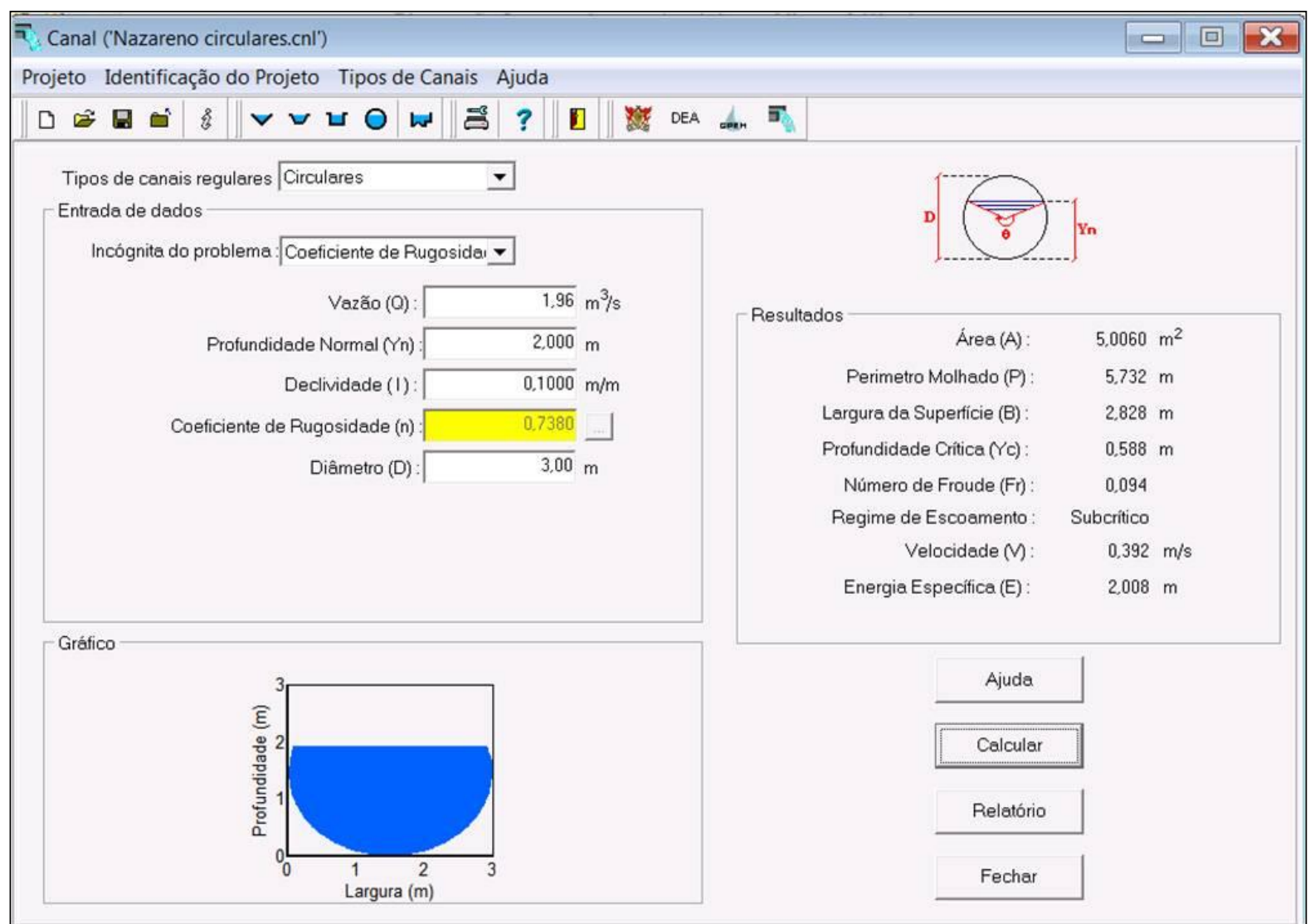

Figura 91 - Canal circular com declividade de $0,1000 \mathrm{~m} \cdot \mathrm{m}^{-1}$. 


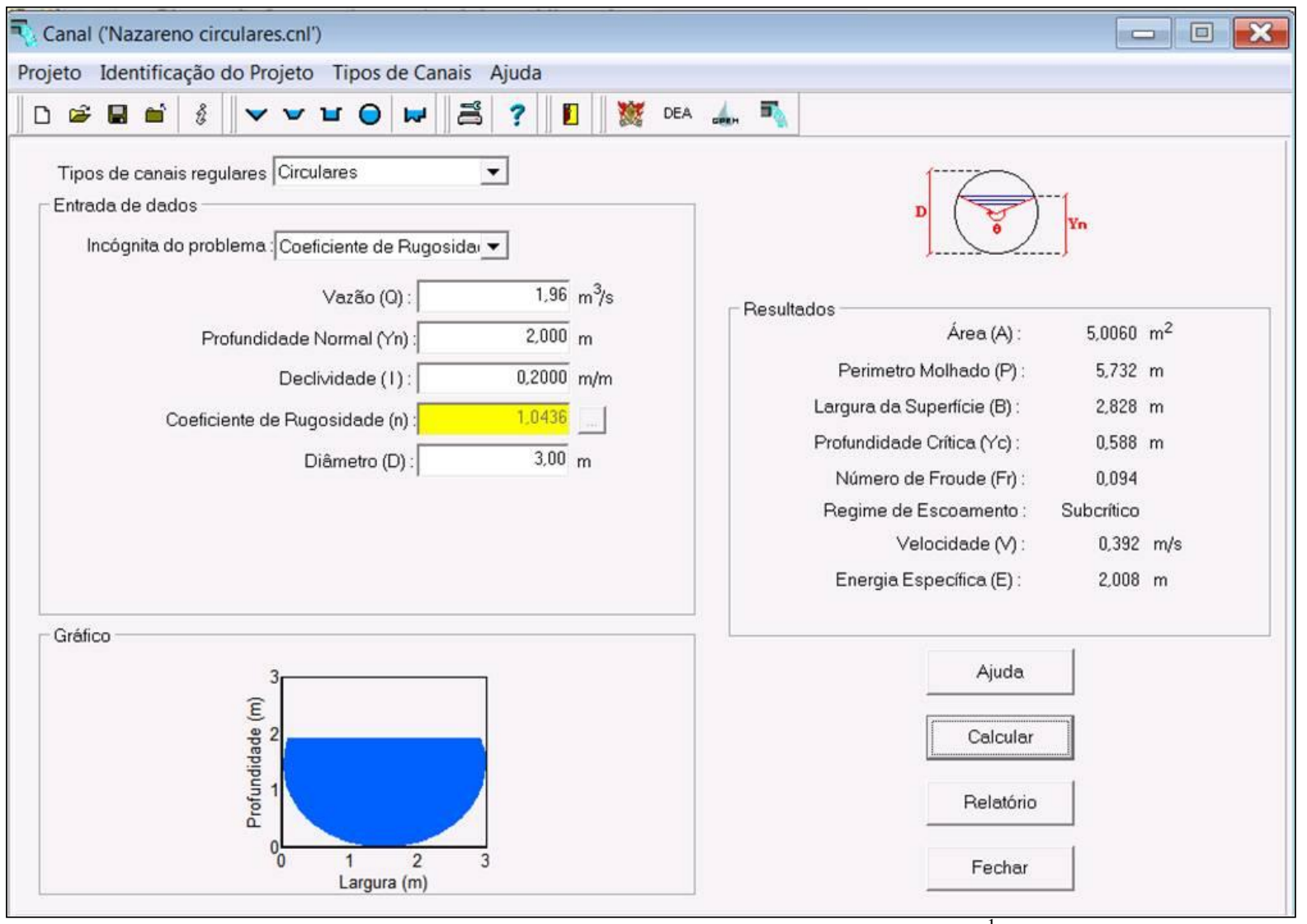

Figura 92 - Canal circular com declividade de $0,2000 \mathrm{~m} \mathrm{~m}^{-1}$.

Verifica-se com estes resultados (Figuras 91 e 92) que, para manter o escoamento subcrítico com baixa velocidade seria necessário que os coeficientes de rugosidade fossem 0,7380 e 1,0436. Ao se observarem os valores para os coeficientes de rugosidade na Tabela 31, é possível verificar que a ordem de grandeza encontrada é extremamente elevada em relação ao que se encontra para ser utilizado para um canal em variados revestimentos, ou seja, para que canais com seções circulares possam ser utilizados nestas condições com garantia de regime e velocidade adequados seria imprescindível algum revestimento que possuísse uma rugosidade altíssima; sendo assim, o mesmo não é recomendado. 
Tabela 31 - Valores do coeficiente de rugosidade da fórmula de Manning. (Adaptada de PORTO, 2006).

Natureza das Paredes

\begin{tabular}{|c|c|c|c|c|}
\hline \multirow[t]{2}{*}{ Natureza das Paredes } & \multicolumn{4}{|c|}{ (Condiçoes das paredes) } \\
\hline & Muito Boas & Boas & Regulares & Más \\
\hline Tubos de ferro fundido sem revestimento & 0,012 & 0,013 & 0,014 & 0,015 \\
\hline $\begin{array}{l}\text { Tubos de ferro, com revestimento de } \\
\text { alcatrão }\end{array}$ & 0,011 & $0,012^{*}$ & $0,013^{*}$ & --- \\
\hline Tubos de ferro galvanizado & 0,013 & 0,014 & 0,015 & 0,017 \\
\hline Tubos de bronze ou de vidro & 0,009 & 0,010 & 0,011 & 0,013 \\
\hline Condutos de barro vitrificado, de esgoto & 0,011 & $0,013 *$ & 0,015 & 0,017 \\
\hline Condutos de barro, de drenagem & 0,011 & $0,012^{*}$ & $0,014^{*}$ & 0,017 \\
\hline $\begin{array}{l}\text { Alvenaria de tijolos com argamassa de } \\
\text { cimentos: condutos de esgoto, de tijolos }\end{array}$ & 0,012 & 0,013 & $0,015^{*}$ & 0,017 \\
\hline Superfícies de cimento alisado & 0,010 & 0,011 & 0,012 & 0,013 \\
\hline Superfícies de argamassa de cimento & 0,011 & 0,012 & $0,013 *$ & 0,015 \\
\hline Tubos de concreto & 0,012 & 0,013 & 0,015 & 0,016 \\
\hline Condutos e aduelas de madeira & 0,010 & 0,011 & 0,012 & 0,013 \\
\hline Calhas de prancha de madeira aplainada & 0,010 & $0,012^{*}$ & 0,013 & 0,014 \\
\hline $\begin{array}{l}\text { Calhas de prancha de madeira, não } \\
\text { aplainada }\end{array}$ & 0,011 & $0,013^{*}$ & 0,014 & 0,015 \\
\hline $\begin{array}{l}\text { Calhas de prancha de madeira, com } \\
\text { pranchões }\end{array}$ & 0,012 & $0,015^{*}$ & 0,016 & --- \\
\hline Canais com revestimento de concreto & 0,012 & $0,014 *$ & 0,016 & 0,018 \\
\hline Alvenaria de pedra argamassa & 0,017 & 0,020 & 0,025 & 0,030 \\
\hline Alvenaria de pedra seca & 0,025 & 0,033 & 0,033 & 0,035 \\
\hline Alvenaria de pedra aparelhada & 0,013 & 0,014 & 0,015 & 0,017 \\
\hline Calhas metálicas lisas (semicirculares) & 0,011 & 0,012 & 0,013 & 0,015 \\
\hline Idem, corrugadas & 0,023 & 0,025 & 0,028 & 0,030 \\
\hline Canais de terra, retilíneos e uniformes & 0,017 & 0,020 & 0,023 & 0,025 \\
\hline Canais abertos em rocha, lisos e uniformes & 0,025 & 0,030 & $0,033^{*}$ & 0,035 \\
\hline $\begin{array}{l}\text { Canais abertos em rocha, irregulares, ou de } \\
\text { paredes de pedra irregulares e mal- } \\
\text { arrumadas }\end{array}$ & 0,035 & 0,040 & 0,045 & --- \\
\hline Canais dragados & 0,025 & 0,028 & 0,030 & 0,033 \\
\hline Canais curvilíneos e lamosos & 0,023 & $0,025^{*}$ & 0,028 & 0,030 \\
\hline $\begin{array}{l}\text { Canais com leito pedregoso e vegetação } \\
\text { aos taludes }\end{array}$ & 0,025 & 0,030 & $0,035^{*}$ & 0,040 \\
\hline $\begin{array}{l}\text { Canais com fundo de terra e taludes } \\
\text { empedrados }\end{array}$ & 0,028 & 0,030 & 0,033 & 0,035 \\
\hline
\end{tabular}

Tentou-se, ainda, estudar a alteração do diâmetro da seção para verificar o que poderia ocorrer com o coeficiente de rugosidade nestas condições. O resultado é observado na Figura 93. 


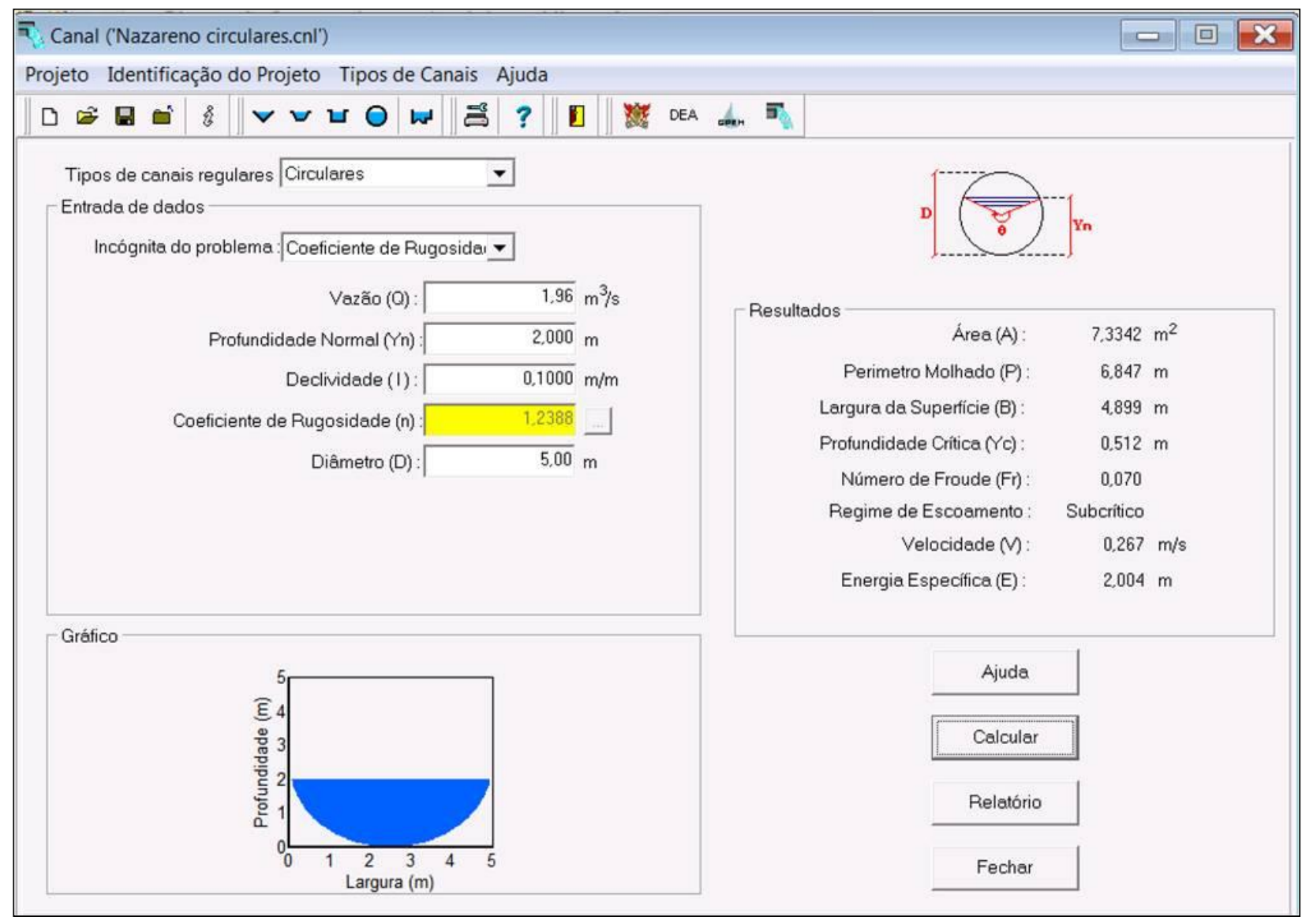

Figura 93 - Canal circular com diâmetro de 5,00 m.

Observou-se, então, que, para que se mantivessem condições adequadas de regime e velocidade de escoamento, o coeficiente de rugosidade deveria aumentar ainda mais com o aumento do diâmetro do canal (1,2388). Sendo assim, considerou-se que os canais circulares nesse caso não são viáveis devido à dificuldade em se encontrar algum material com estes valores de coeficiente de rugosidade.

Em seguida, efetuaram-se as avaliações para seções de canal trapezoidais. Fixaram-se os parâmetros de profundidade normal de 1,0 m, folga de $30 \mathrm{~cm}$, largura de base de 2,0 m e inclinação do talude de 1, para que se mantivessem condições viáveis, tanto tecnológica quanto financeiramente, de construção na área, e de forma a se obter segurança com alguns valores, como o da folga. As Figuras 94 e 95 apresentam os resultados obtidos. 


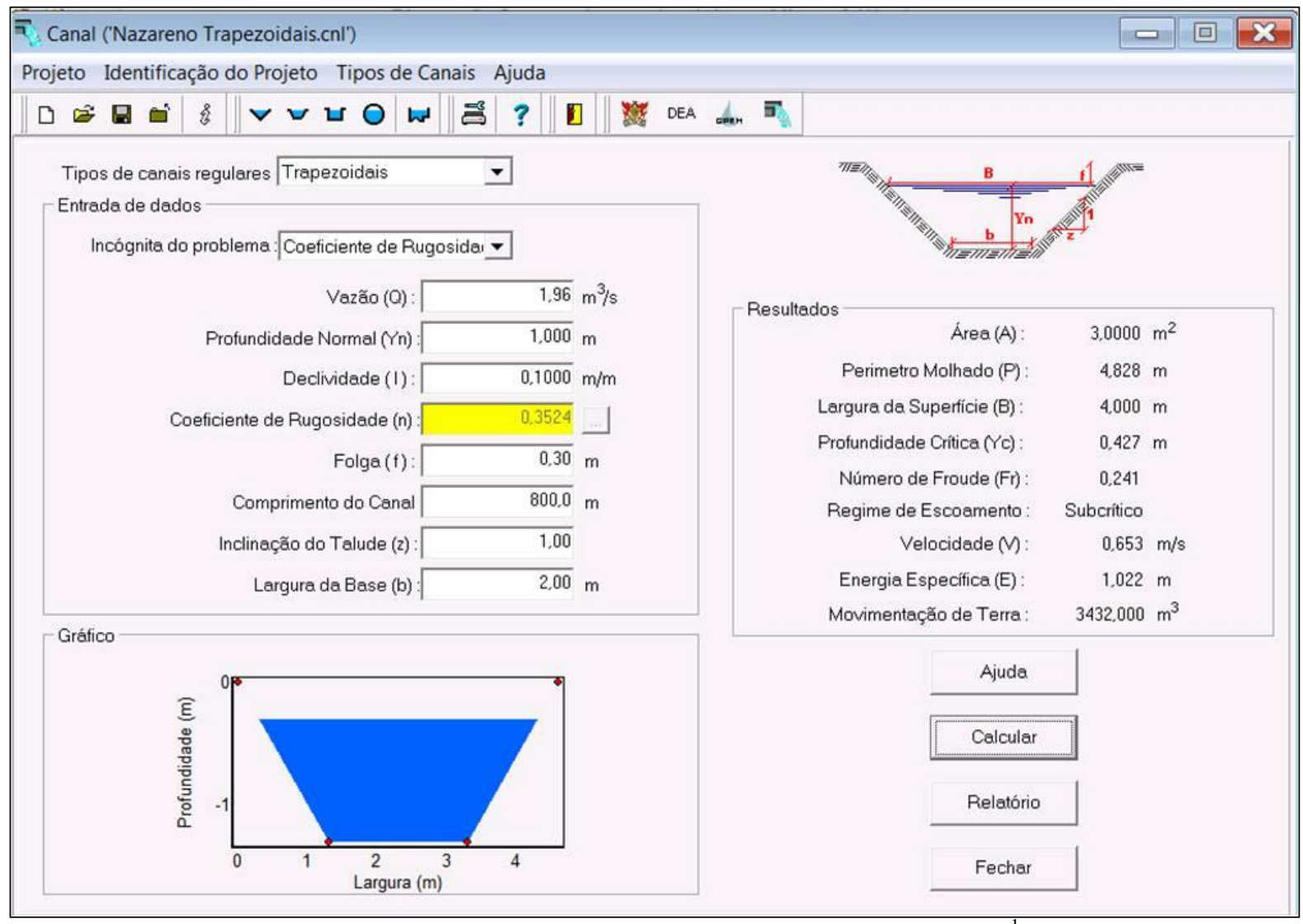

Figura 94 - Canal trapezoidal com declividade de $0,1000 \mathrm{~m} \cdot \mathrm{m}^{-1}$.

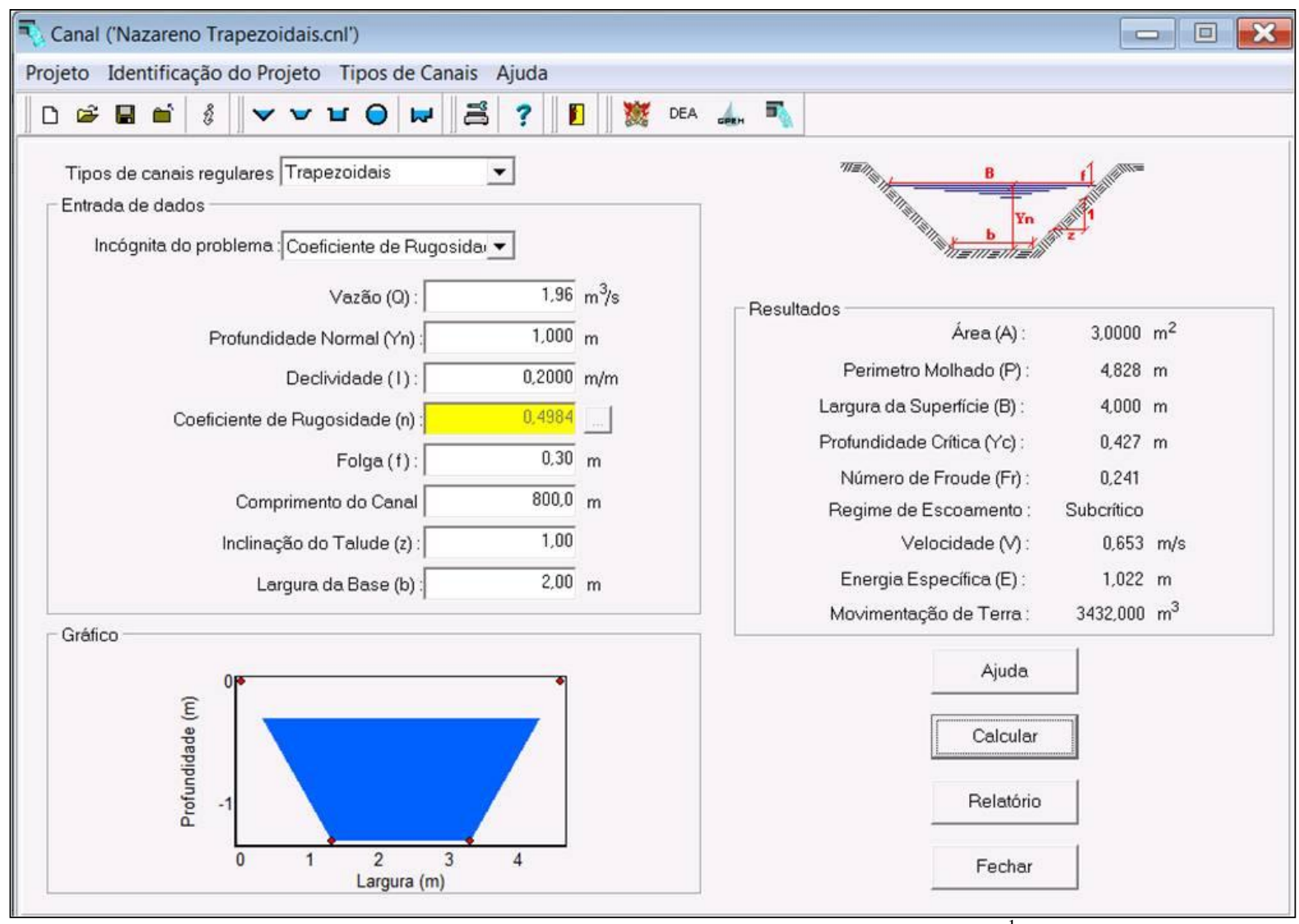

Figura 95 - Canal trapezoidal com declividade de $0,2000 \mathrm{~m} \cdot \mathrm{m}^{-1}$. 
O software aponta, nestes dois casos, que apenas o coeficiente de rugosidade se altera com a alteração das declividades do terreno. Isto quer dizer que com o aumento da declividade do terreno a condição ideal para que se mantenha o regime de escoamento seria elevar a rugosidade do canal. Porém, ao observar-se a Tabela 31, considerando-se um canal de terra retilíneo e uniforme, o coeficiente de rugosidade apresenta valores de 0,02300 a 0,02000 em condições de regulares a boas, não sendo os valores encontrados pelo software condizentes com estes $(0,3524$ e 0,4984$)$.

Dessa forma, novos cálculos foram realizados com o software, desta vez, fixando-se o coeficiente de rugosidade nestes valores, deixando-se a declividade do terreno como incógnita. Os resultados são apresentados na Figura 96 e 97.

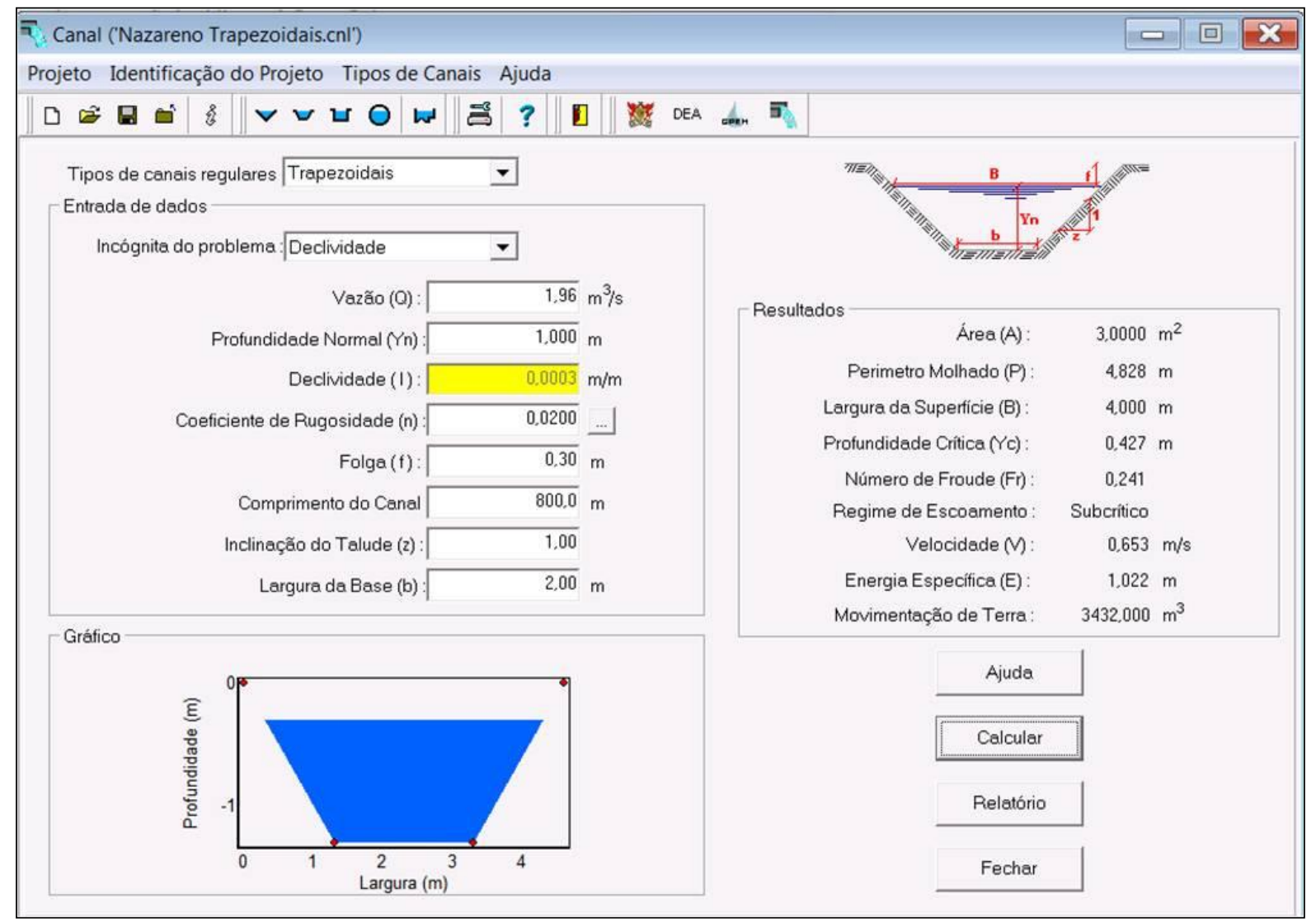

Figura 96 - Canal trapezoidal com coeficiente de rugosidade de 0,0200. 


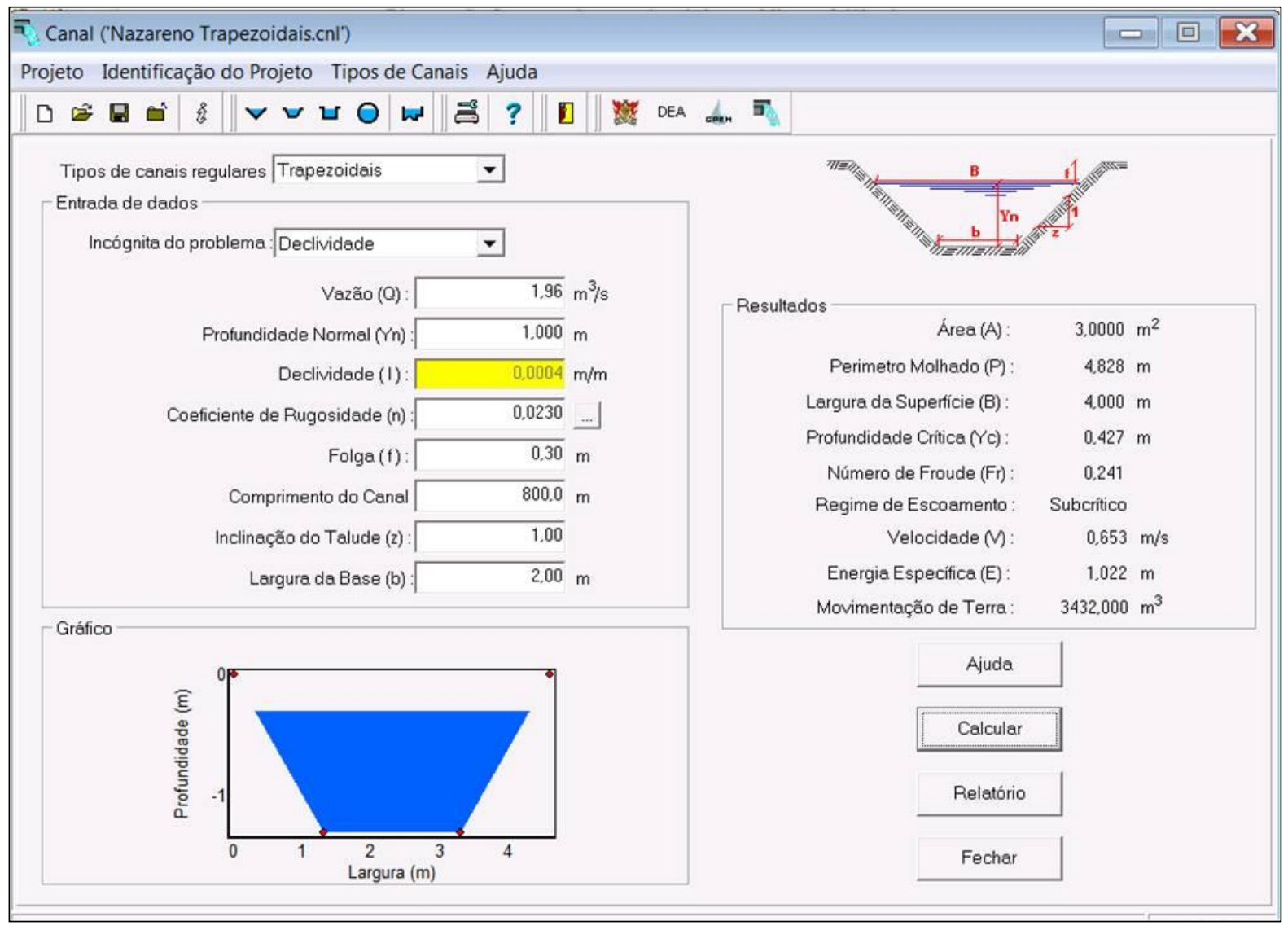

Figura 97 - Canal trapezoidal com coeficiente de rugosidade de 0,0230.

Observa-se que, para que o canal mantenha condições de escoamento ideais e com o coeficiente de rugosidade citado, a declividade do terreno deveria ser da ordem de 0,0003 e 0,0004 m.m $\mathrm{m}^{-1}$, o que não condiz com a declividade do terreno. Para condições sem nenhum tipo de material que altere o valor da rugosidade, a declividade deveria ser corrigida quando da implantação dos canais.

Diante disso, optou-se por analisar a situação na qual o canal poderia ser revestido por vegetação e/ou geomanta (sendo que para esta última considerou-se a rugosidade com mesmo valor que o de revestimento de vegetação) e por leito com pedregulhos ou pedras de mão, isto é, coeficiente de rugosidade de 0,0300 em boas condições (Tabela 31). O resultado obtido é apresentado na Figura 98. 


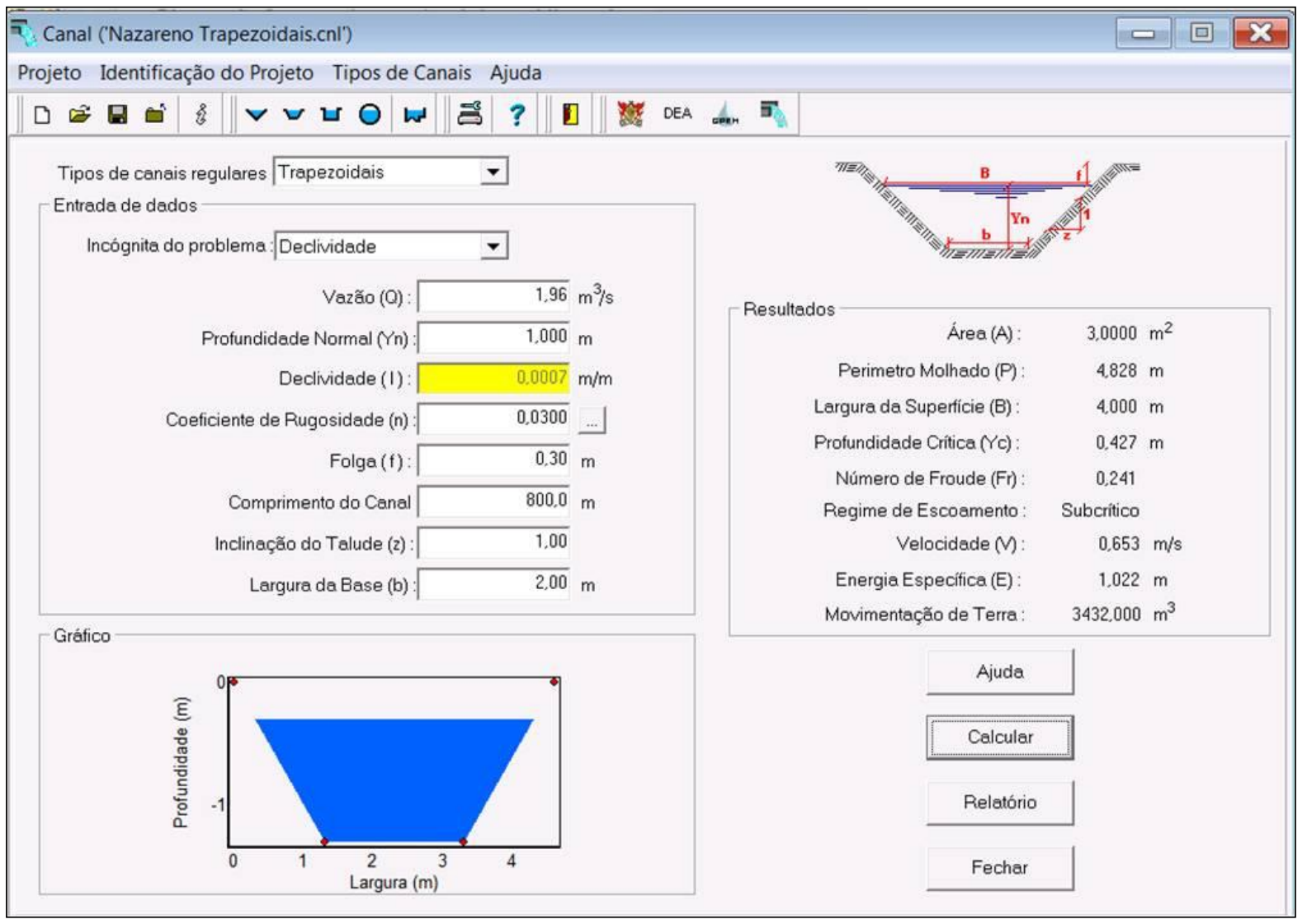

Figura 98 - Canal trapezoidal com coeficiente de rugosidade de 0,0300.

Verifica-se que a declividade do terreno a ser corrigida se eleva com este coeficiente de rugosidade em relação àquelas encontradas anteriormente. Entretanto, ao comparar-se este valor com o mínimo encontrado para o terreno, tem-se que, para se chegar a este resultado ideal, a declividade deveria ser reduzida.

Verificou-se a necessidade de se estudar o comportamento da vazão conforme fixados o coeficiente de rugosidade e a declividade do terreno, para condições de revestimento de vegetação e leito com pedregulhos e declividades variando entre a 0,1000 e 0,2000 m.m ${ }^{-1}$. Os resultados obtidos são apresentados nas Figuras 99 e 100. 


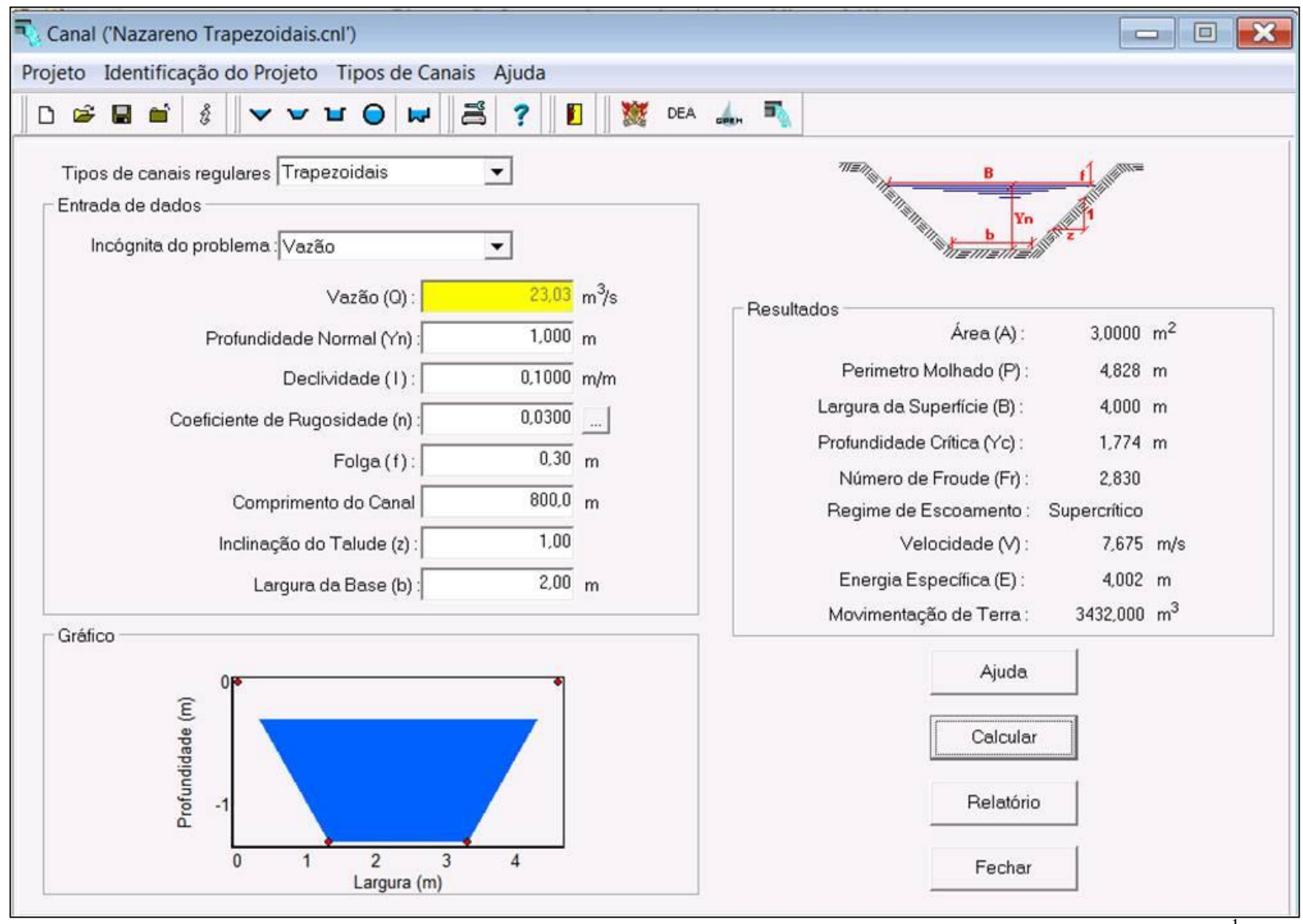

Figura 99 - Canal trapezoidal com coeficiente de rugosidade de 0,0300 e declividade de $0,1000 \mathrm{~m} \mathrm{~m}^{-1}$.

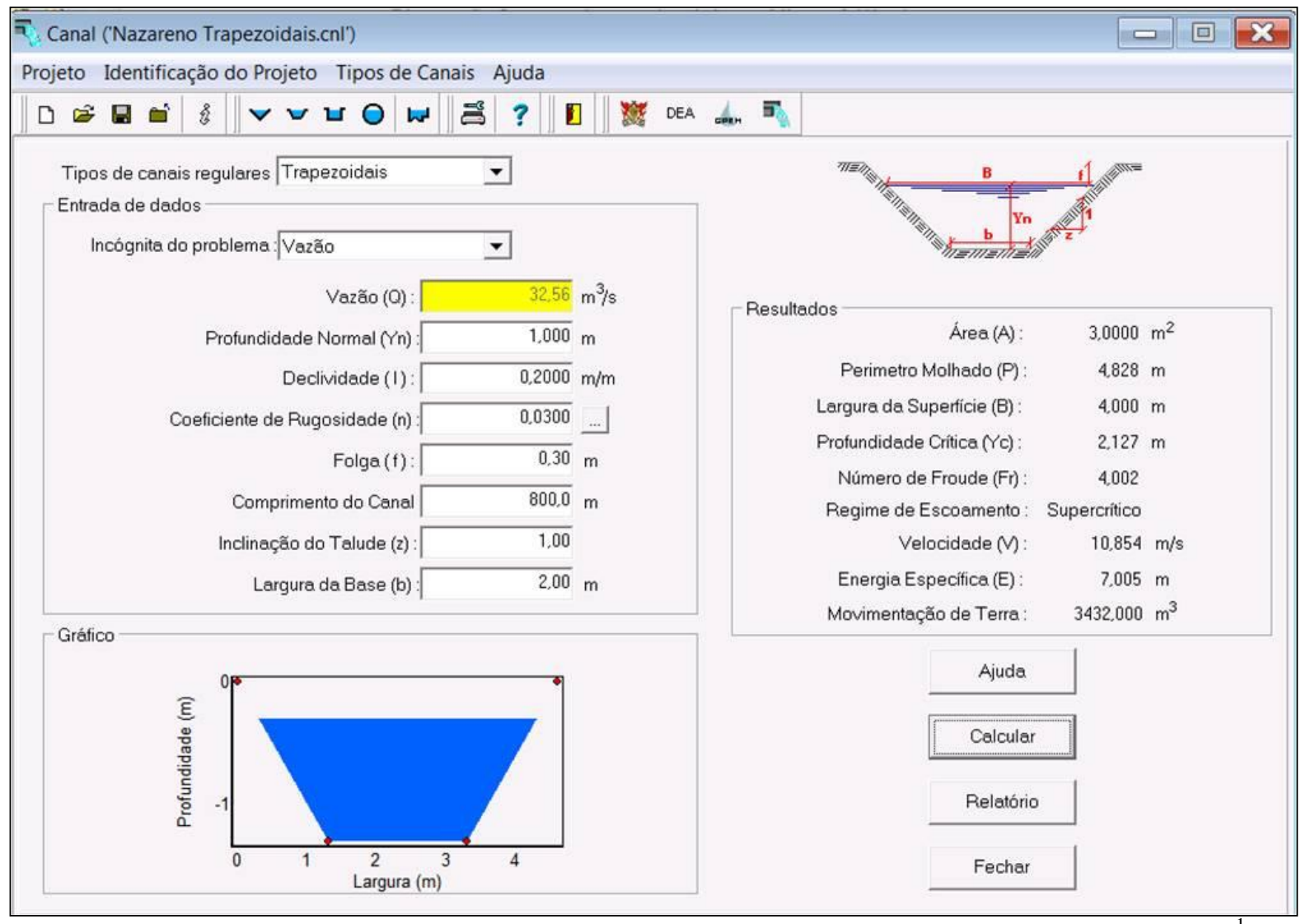

Figura 100 - Canal trapezoidal com coeficiente de rugosidade de 0,0300 e declividade de 0,2000 m.m ${ }^{-1}$. 
Os resultados apontam que a declividade do terreno pode influenciar bruscamente a vazão, a velocidade de escoamento e o regime para os canais. Mesmo com rugosidade elevada, a vazão teve um aumento de quase 11,75 e 16,61 vezes para as condições da Figuras 99 e 100, sendo que as velocidades encontradas foram de $7,675 \mathrm{~m} . \mathrm{s}^{-1}$ e $10,854 \mathrm{~m} . \mathrm{s}^{-1}$, respectivamente. Isto demonstra que um comportamento turbulento da água pode ser gerado pelas declividades naturais da voçoroca, mesmo em locais onde exista vegetação estabelecida, o que facilmente pode desagregar o solo com pouca coesão presente na área; além disso, as elevadas velocidades podem arrastar as partículas não somente para o interior da voçoroca, como também para cursos d'água e/ou canais pluviais a jusante, causando o assoreamento.

A partir deste estudo é possível depreender que a declividade do terreno e a rugosidade do canal influenciam fortemente a velocidade e o regime de escoamento superficial da área de entorno da voçoroca.

Uma proposta que poderia auxiliar na redução das inclinações sem a realização de uma interferência direta no solo seria o conceito de declividade de compensação apresentado por Durlo e Sutili (2005).

O perfil de compensação em um curso d'água pode auxiliar a estabilizar o escoamento a partir da concepção de que, utilizando-se uma estrutura que cause desnível no terreno, além de haver um acúmulo de sedimentos em sua base que proporcionaria uma suavização na inclinação do escoamento, haveria também a dissipação de energia e redução na velocidade deste escoamento, e como consequência, haveria redução na capacidade de erosão do canal (DURLO; SUTILI, 2005).

A Figura 101 apresenta a conformação de um perfil de compensação formado pela presença de uma barragem de consolidação. 


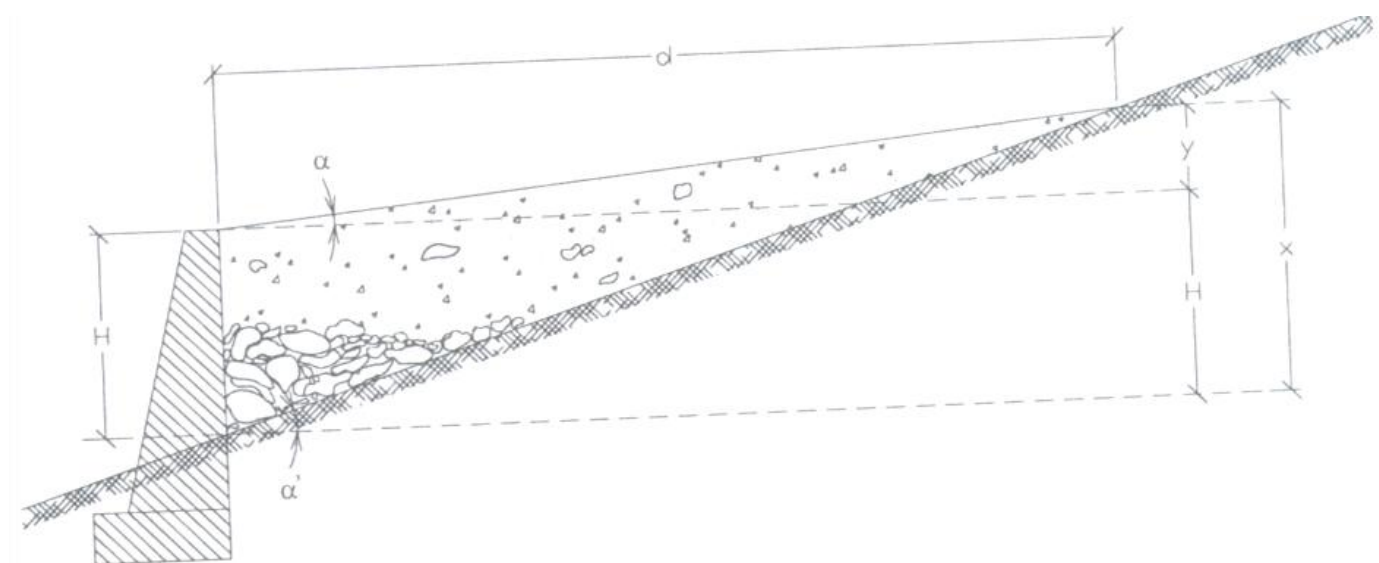

Figura 101 - Distância corrigida por uma barragem de consolidação. (DURLO E SUTILI, 2005).

Neste caso, $d$ representa a distância a ser corrigida pela barragem, $H$ seria a altura da barragem, $\alpha$ seria o ângulo obtido no perfil de compensação, $\alpha$ ' seria o ângulo atual de declividade do terreno, $y$ seria a altura aproximada encontrada para a distância corrigida e $x$ a soma de $y$ e $H$. Aplica-se, então, a semelhança de triângulos para se encontrar estas dimensões; no caso de se cogitar a implementação de mais de uma destas estruturas ao longo do canal para formar-se uma escada d'água, pode-se utilizar deste mesmo raciocínio para estimar-se o distanciamento entre uma estrutura e outra.

Estas estruturas transversais, também denominadas soleiras ou cintos basais (em menor porte), necessitam de especial atenção na base à jusante de sua construção, pois o escoamento alterado pela barragem pode causar uma turbulência neste local; a priori, esta turbulência pode auxiliar na dissipação de energia da água (PORTO, 2006), porém, esta mesma turbulência pode desencadear processos erosivos indesejáveis no canal, sendo interessante a inclusão de pedregulhos ou pedras de mão nesse local para reduzir o impacto da água com o solo (DURLO; SUTILI, 2005) (Figura 102).
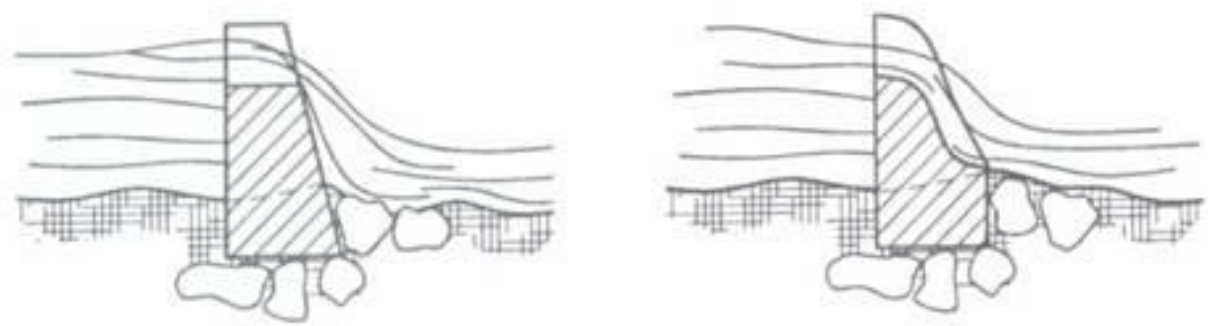

Figura 102 - Soleiras do tipo inclinada (esquerda) e sinoidal (direita). Modificada de Durlo e Sutili (2005). 
A Figura 103 apresenta uma barragem de consolidação e seus componentes, de acordo com técnicas de bioengenharia de solos, que poderia ser utilizada na área de estudo para formar a declividade de compensação.

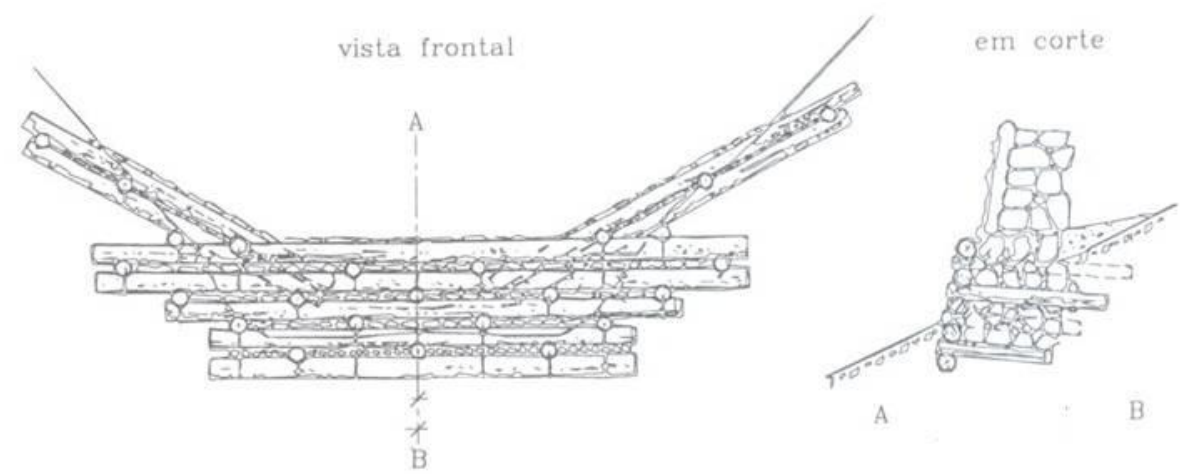

Figura 103 - Barragem de consolidação construída em madeira e pedras. Modificada de Durlo e Sutili (2005).

É necessário atentar para o fato de que a presença de qualquer estrutura que funcione como barreira em um canal poderá causar alteração nas características do escoamento. Um exemplo é o ressalto hidráulico. Ao ocorrer uma elevação repentina no nível da água em pequenas distâncias pode haver alteração na estabilidade da superfície do escoamento, com introdução de ar, de maneira que haja transição do regime supercrítico para subcrítico com a dissipação da energia cinética (Figura 104) (PORTO, 2006). É importante manter a cautela na implantação do projeto para que o fundo e as paredes dos canais estejam bem consolidados, pois uma turbulência ou o ressalto hidráulico podem causar desagregação do solo, caso o revestimento não esteja em boas condições, ou o destacamento dos pedregulhos, caso não tenham sido bem dispostos ou não tenham dimensões apropriadas. 


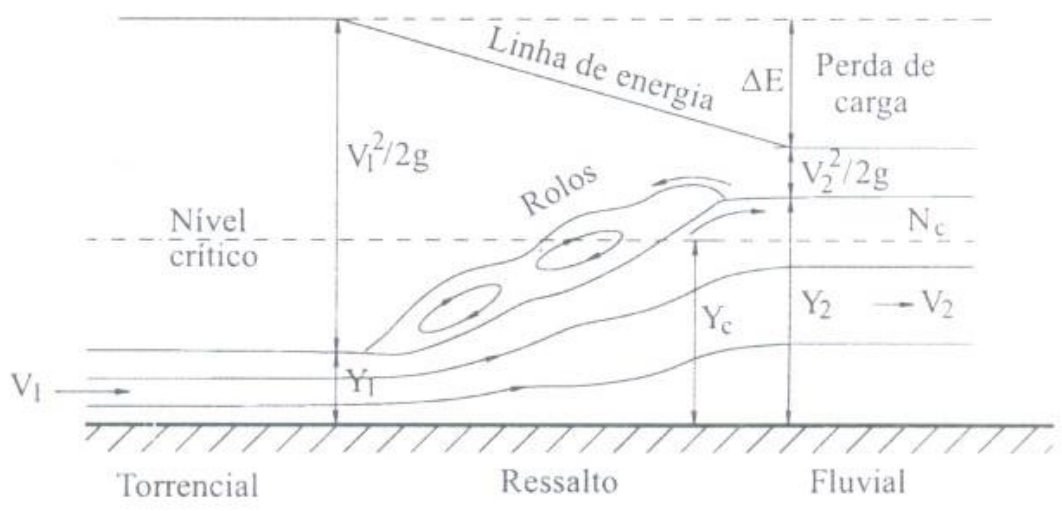

Figura 104 - Ressalto hidráulico (PORTO, 2006).

Pode ser utilizado, em conjunto com a drenagem da água superficial, um terraço ou camalhão de base estreita, de formato suave e arredondado, para conduzir o escoamento superficial para os canais propostos (DAEE/IPT, 1989), como indica a Figura 105.

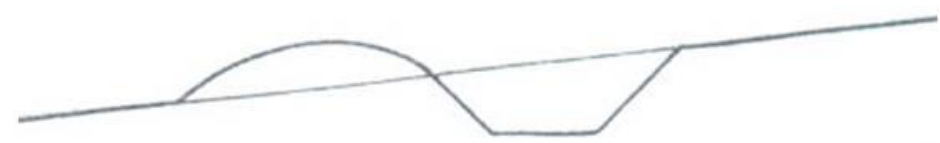

Figura 105 - Terraço em base estreita (DAEE/IPT, 1989).

\subsection{2 Área InTERnA DA VoÇOrocA - Drenagem dA ÁGUA SubSUPERFICIAL}

Como observado em visita de campo, a parte interna da voçoroca do Córrego do Cravo já apresenta o nível d'água subterrâneo em afloramento (Figura 106). 


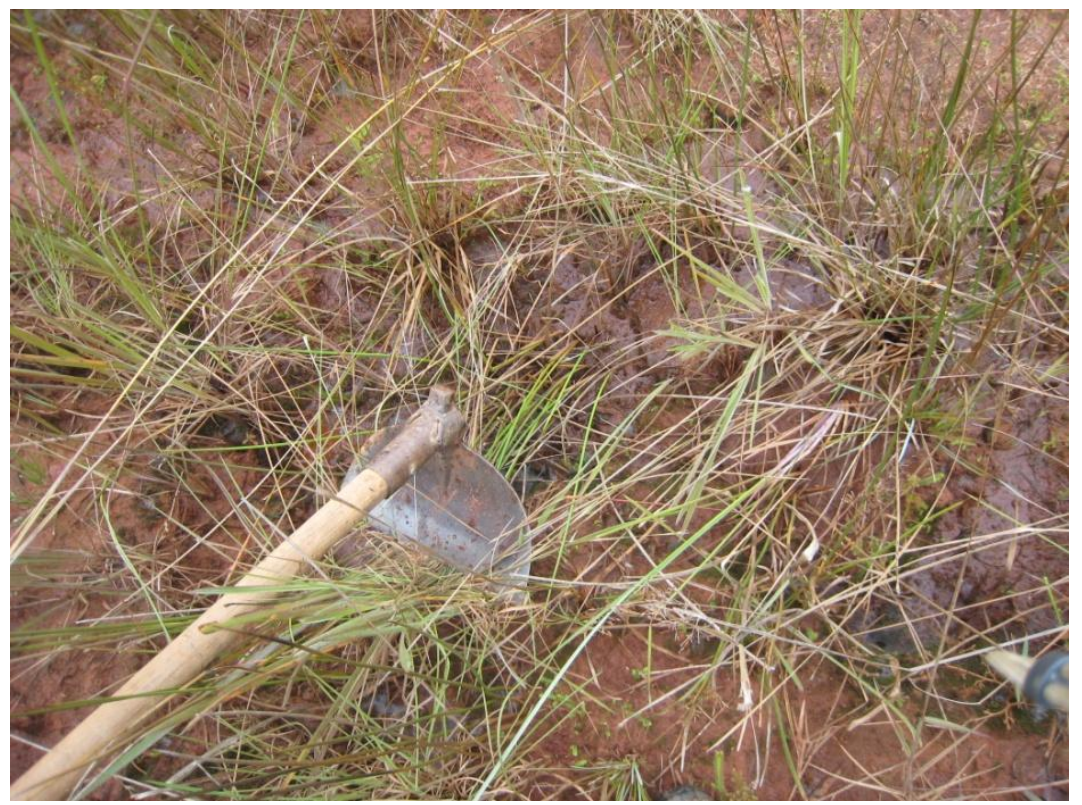

Figura 106- Afloramento de nível d'água subterrâneo na voçoroca do Córrego do Cravo, em Nazareno/MG.

Em muitos locais é possível verificar o aparecimento de pequenos canais de drenagem (Figura 107), e até uma área alagada (Figura 108) foi observada próxima a um dos braços da voçoroca.
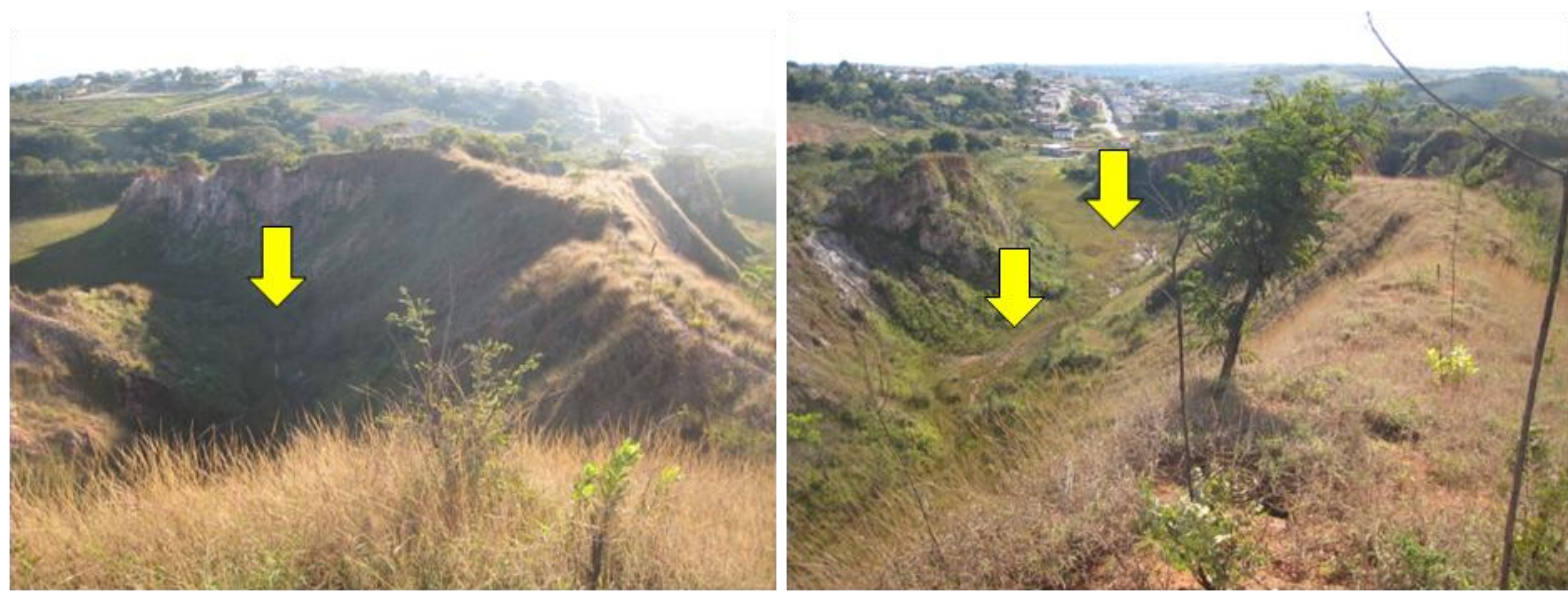

Figura 107 - Canais internos formados pelo afloramento do nível d'água subterrâneo na voçoroca do Córrego do Cravo, Nazareno/MG. 


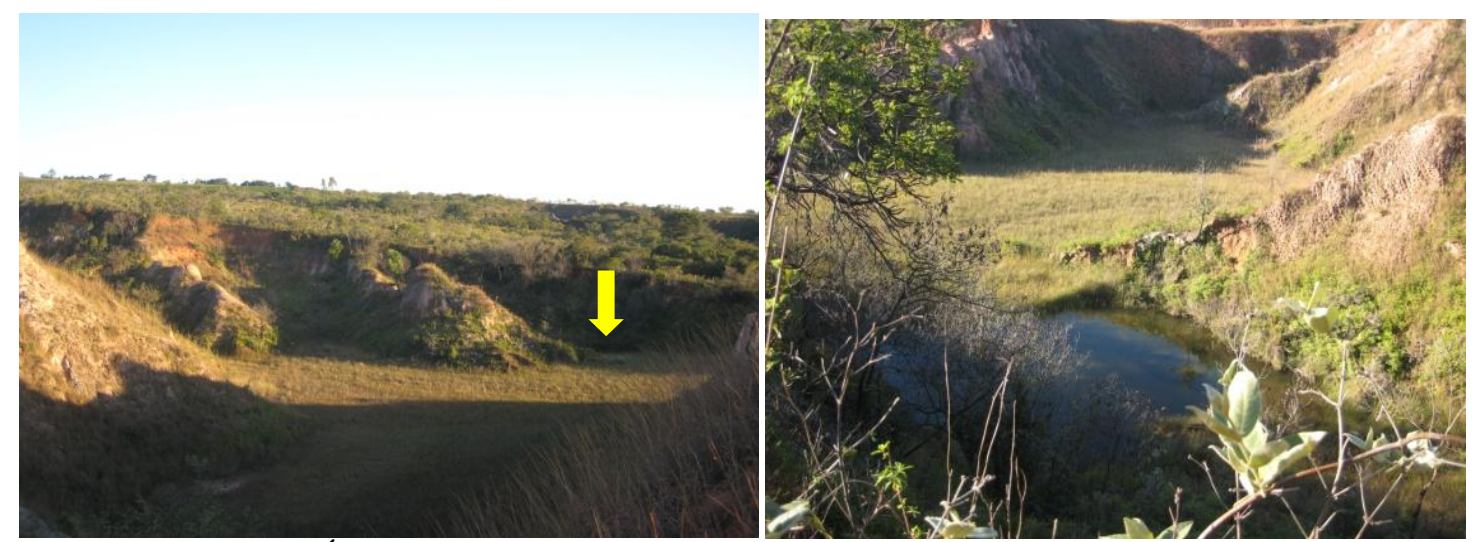

Figura 108 - Área alagada no interior da voçoroca do Córrego do Cravo, Nazareno/MG.

Duas observações realizadas em campo merecem destaque neste ponto: a primeira delas é a de que a água subterrânea ainda causa a desestabilização do solo saprolítico encontrado na base da voçoroca, sendo possível verificar em vários pontos o aparecimento de pipings ou sumidouros nos topos e nas encostas dos braços da voçoroca (aumentando a frequência conforme se caminha para jusante) e a presença de escorregamentos de médio e pequeno porte nas encostas, como mostram as Figuras 109, 110 e 111.

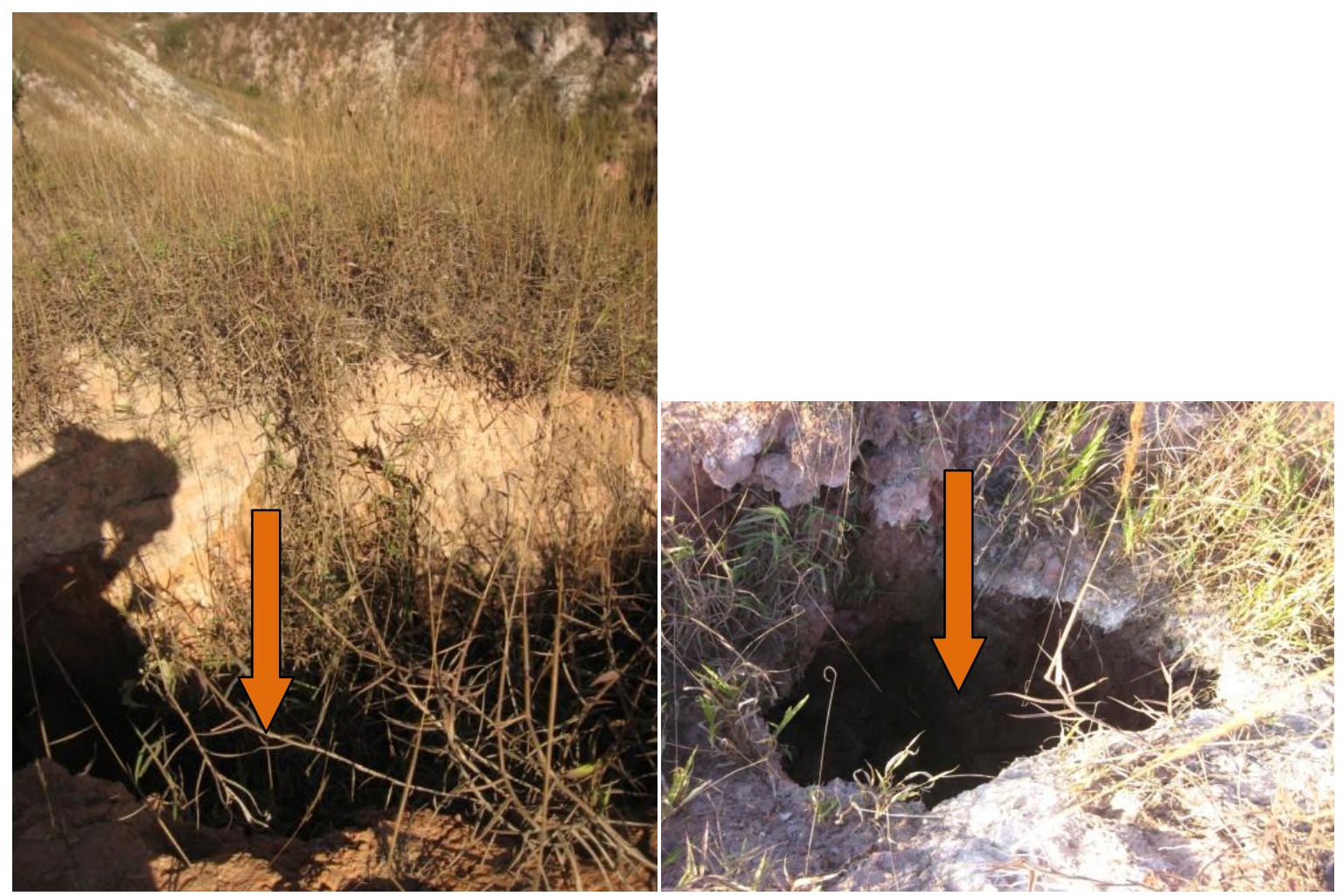

Figura 109 - Pipings e sumidouros observados desde os topos de braços da voçoroca do Córrego do Cravo, Nazareno/MG. 


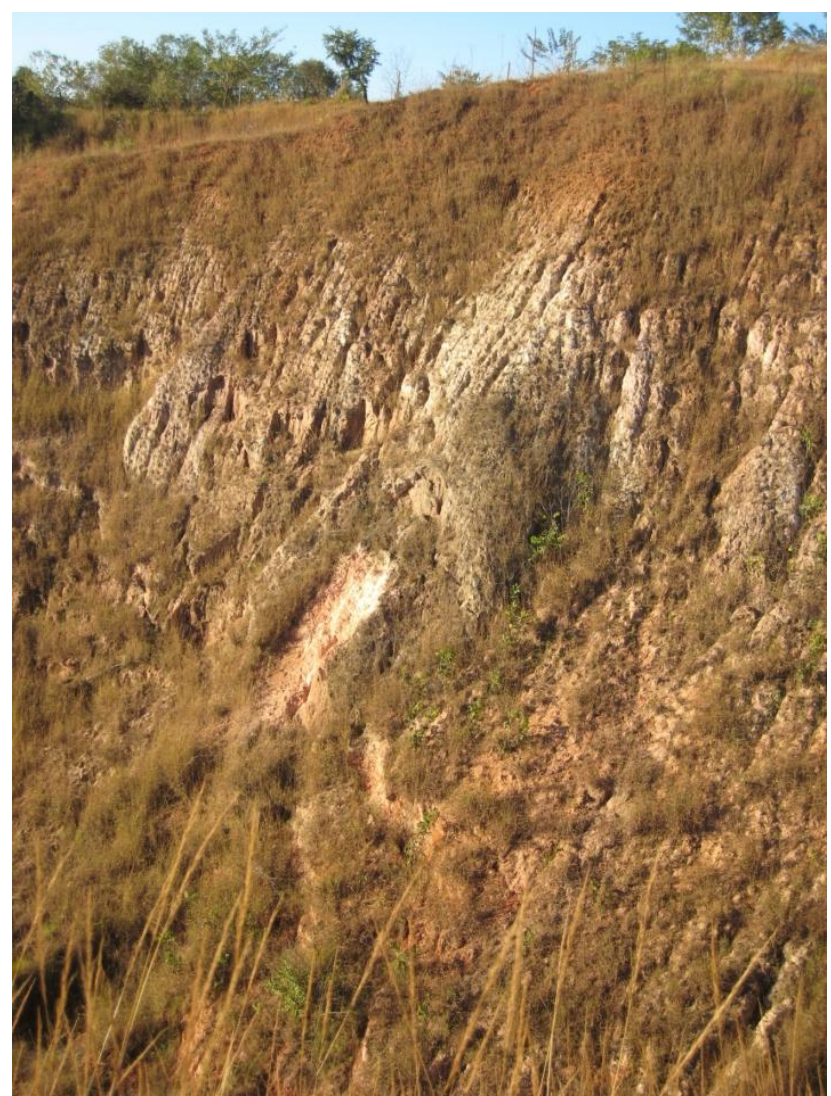

Figura 110 - Pipings na base, pequenos escorregamentos e sulcos na encosta em um dos braços da voçoroca do Córrego do Cravo, Nazareno/MG.

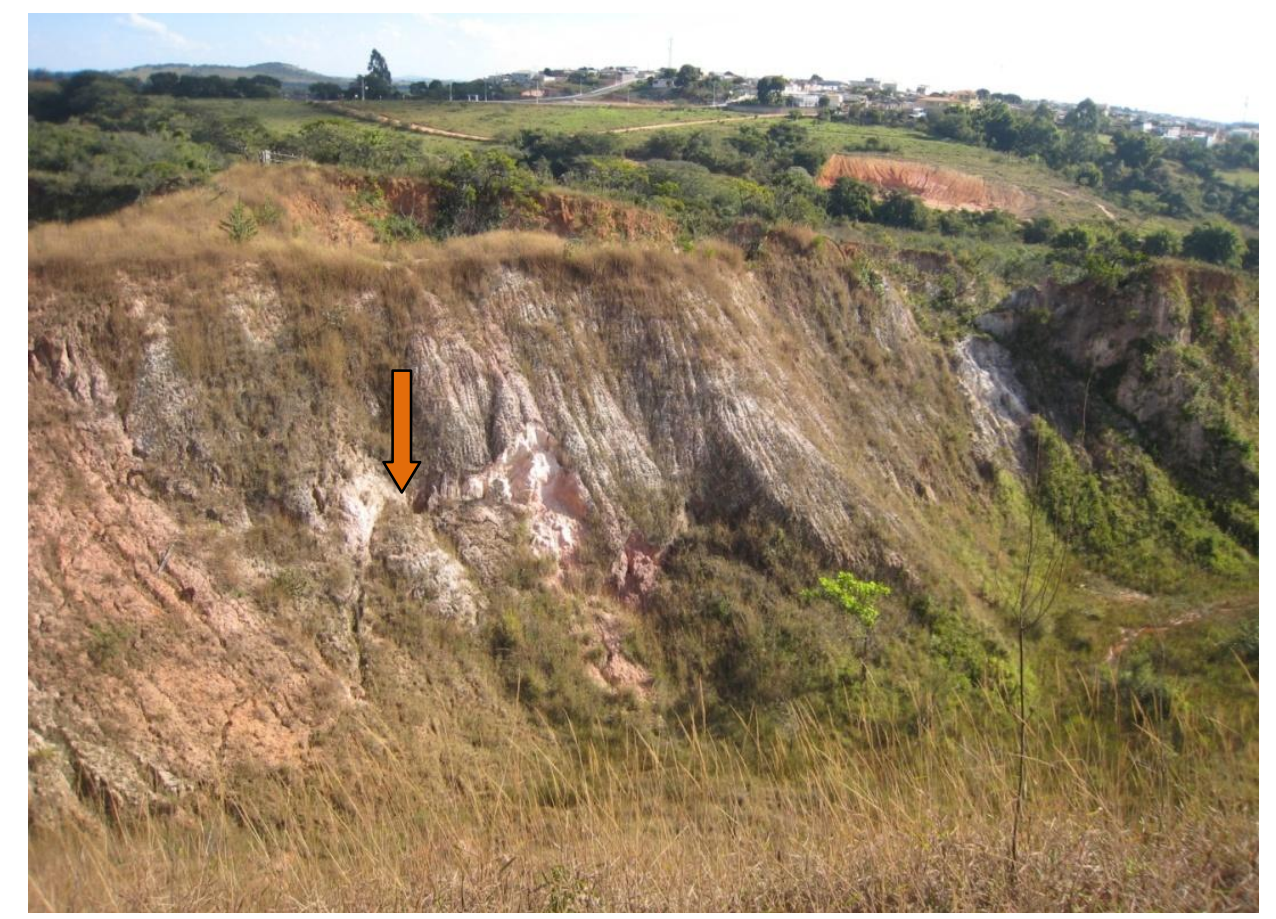

Figura 111 - Sulcos e escorregamentos de médio porte em encosta de um dos braços da voçoroca do Córrego do Cravo em Nazareno/MG. Possível verificar na extrema esquerda uma fissura apontando possibilidade de escorregamento futuro. 
A segunda observação realizada foi a de que, no interior da voçoroca mais próximo ao cafezal, podem ser vistas pteridófitas (em geral, samambaias) e árvores de maior porte em desenvolvimento (Figura 112), o que leva à consideração de que, mesmo a área apresentando solos pobres em nutrientes, a declividade menos acentuada e a disponibilidade perene de água permite o estabelecimento e sucessão da vegetação. $\mathrm{O}$ surgimento de pteridófitas como indicadores de revegetação foi citado por Silva (1990), e esta consideração apontada sobre a disponibilidade de água corrobora Farias (1992) apud Ferreira e Ferreira (2009), o qual, acrescenta, ainda, que a variabilidade das condições de oxigênio também influenciam a presença e distinção de portes vegetativos.

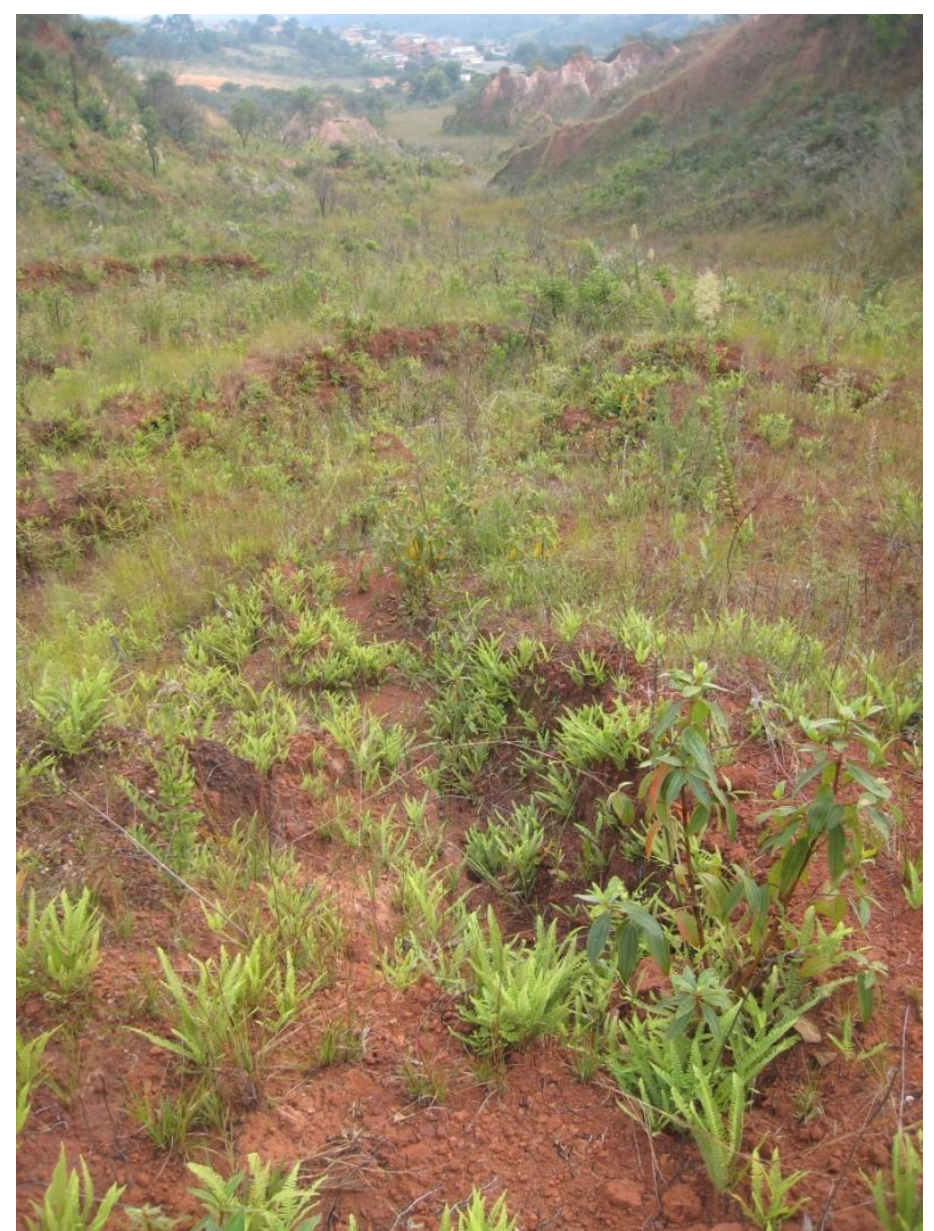

Figura 112 - Sucessão de vegetação no interior da voçoroca do Córrego do Cravo em Nazareno/MG.

Partindo-se destas considerações e do pressuposto de que o interior da voçoroca já se apresenta como um fundo de vale, considerou-se que esta poderia ser a função dada para sua reabilitação interna, e que a configuração que a este ambiente poderia ser dirigida seria a de 
estágio 2, segundo os processos fluviais mostrados na Figura 113. Apesar de não se apresentarem definições ou explicações sobre o por quê e como eles ocorrem, consideram-se os meandros como uma tendência natural de ocorrência em cursos d'água, que não depende de sua escala ou do tipo de sedimento e material inconsolidado da região; geralmente associadas a uma propriedade de turbulência ou como resultado da interação entre o fluxo e o fundo de canais, as curvas de rio apresentam a característica de serem reguladoras destes fundos de canais (KNIGHTON, 1998).

Estágio 1

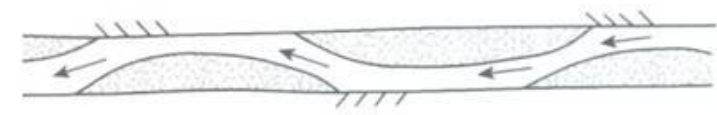

Estágio 2

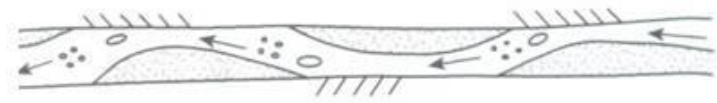

Estágio 3
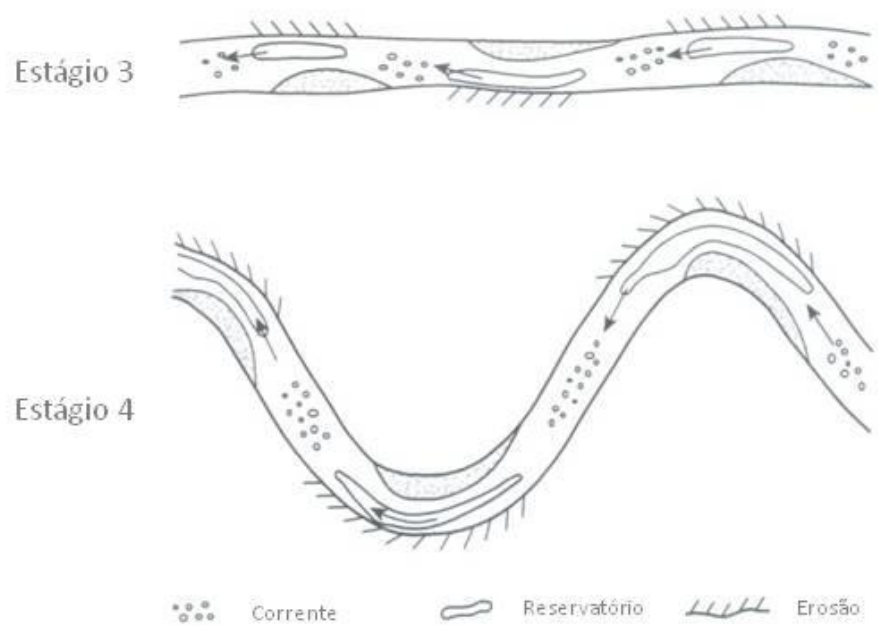

Figura 113 - Transformação de um canal reto com um sistema corrente-reservatório em um canal meandrante (Modificada de KELLER, 1972 apud KNIGHTON, 1998).

Dessa forma, propõe-se a realização de bancos de sedimentos para auxiliar a direção do fluxo na declividade interna e posterior fixação de vegetação de grande porte que possua maior capacidade de absorção de água para auxiliar a drenar esta parte da voçoroca, em conjunto com o direcionamento e tratamento dos cursos d'água encontrados em seu interior, realizados por drenos feitos de feixes vivos (detalhados mais adiante), nas regiões que, como visto, já apresentam canais. Esta proposta tem por finalidade auxiliar no estabelecimento e na 
tendência natural do equilíbrio no fundo da voçoroca, seguindo conceito exposto anteriormente de Knighton (1998).

Cada seção em que se encontrariam estes bancos de sedimentos poderia ter o funcionamento semelhante a uma várzea de um canal natural somados a uma área de altura superior; esta última seria uma alternativa para evitar que o movimento de subida e descida da água com as chuvas afete diretamente a encosta, procurando-se, assim, evitar a ocorrência de pipings. Com o plantio de vegetação arbustiva e de grande porte, estes locais poderiam ser melhor drenados e reforçados com a presença das raízes.

Poderiam ser analisadas espécies de maior porte para plantio nesses bancos de sedimento, que se adaptem bem em ambientes de deposição e baixadas úmidas, como algumas citadas por Ferreira e Ferreira (2009), como Acácia mangium, Angicos (amarelo ou vermelho), Araçá, Aroeiras (branca, do sertão ou aroeirinha), Calabura, Capixingui, Copaíba, Dedaleiro, Embaúba, Eritrina, Genipapo, Goiabeira, Graviola, Guanandi, Ingá, Ipês (amarelo ou roxo), Jacarandá mimoso, Leucena, Mutamba, Paineira, Peito de pombo, Peroba rosa, Pitanga, Piteira, Salís, Sebastiana, Sibipiruna, Sombreiro, Tamboril, Uvaia.

A drenagem interna poderia reduzir a desestabilização nas bases das encostas da voçoroca, a partir da função de recolhimento da água destas áreas e direcionamento do escoamento por feixes vivos, como descrevem Durlo e Sutili (2005). Este tipo de tratamento é indicado quando, nas condições de campo, não é observada estabilidade do leito fluvial (DURLO; SUTILI, 2005); no caso desta pesquisa, será considerado que o nível d'água subterrâneo que se encontra aflorante e com concentração em canais se comporta como um pequeno leito de rio. Dessa forma, esta proposta teria como finalidade, também, revestir e estabilizar estas áreas que seriam talvegues ou córregos em desenvolvimento.

Seria necessário ajustar a declividade do interior para que a água, por gravidade, fosse encaminhada para os feixes. Estes seriam compostos de espécies vegetais vivas amarradas por material mais resistente, inseridos no leito do canal, sendo estas configurações melhor visualizadas nas Figuras 114 e 115. Propõe-se um revestimento lateral destes canais com geomanta para auxiliar na retenção dos sedimentos e resistência destes locais, desde que utilizadas com cautela, pois sua colmatação pode reduzir sua eficiência. 


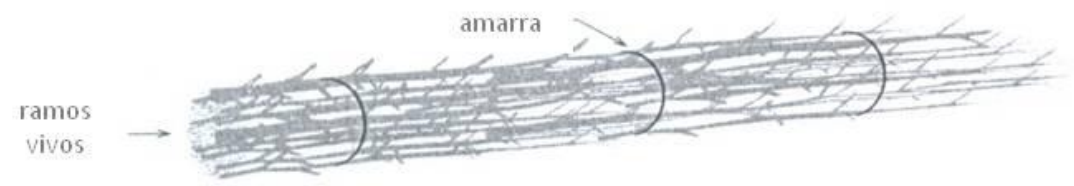

Figura 114 - Feixe vivo adaptado de Durlo e Sutili (2005).

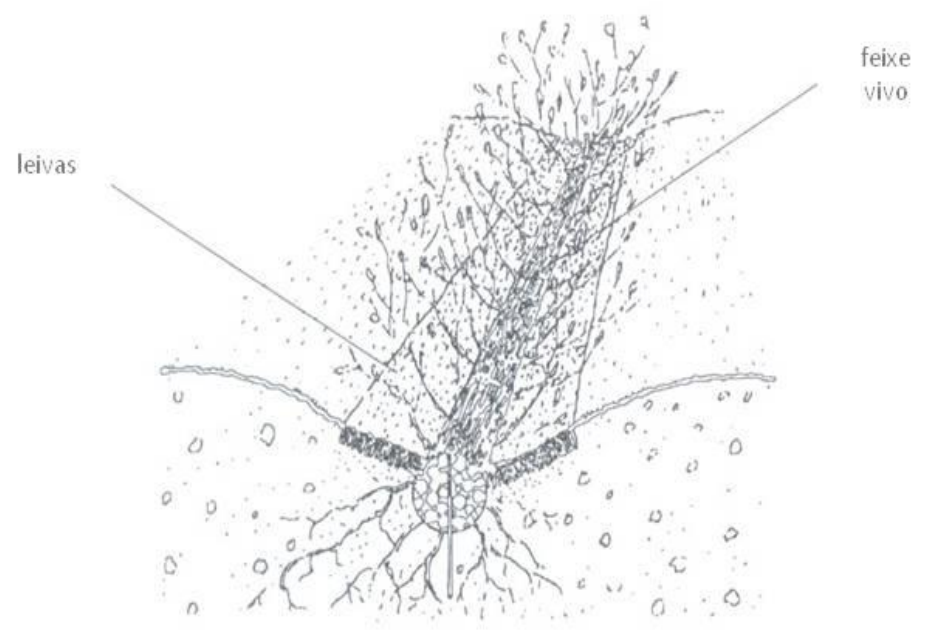

Figura 115 - Feixe (cilindro vivo) adaptado de Durlo e Sutili (2005).

A Figura 116 apresenta um croqui da seção proposta contendo os bancos de sedimentos com vegetação desenvolvida e com a inserção dos feixes vivos, apresentando a concepção de fundo de vale no interior da voçoroca.

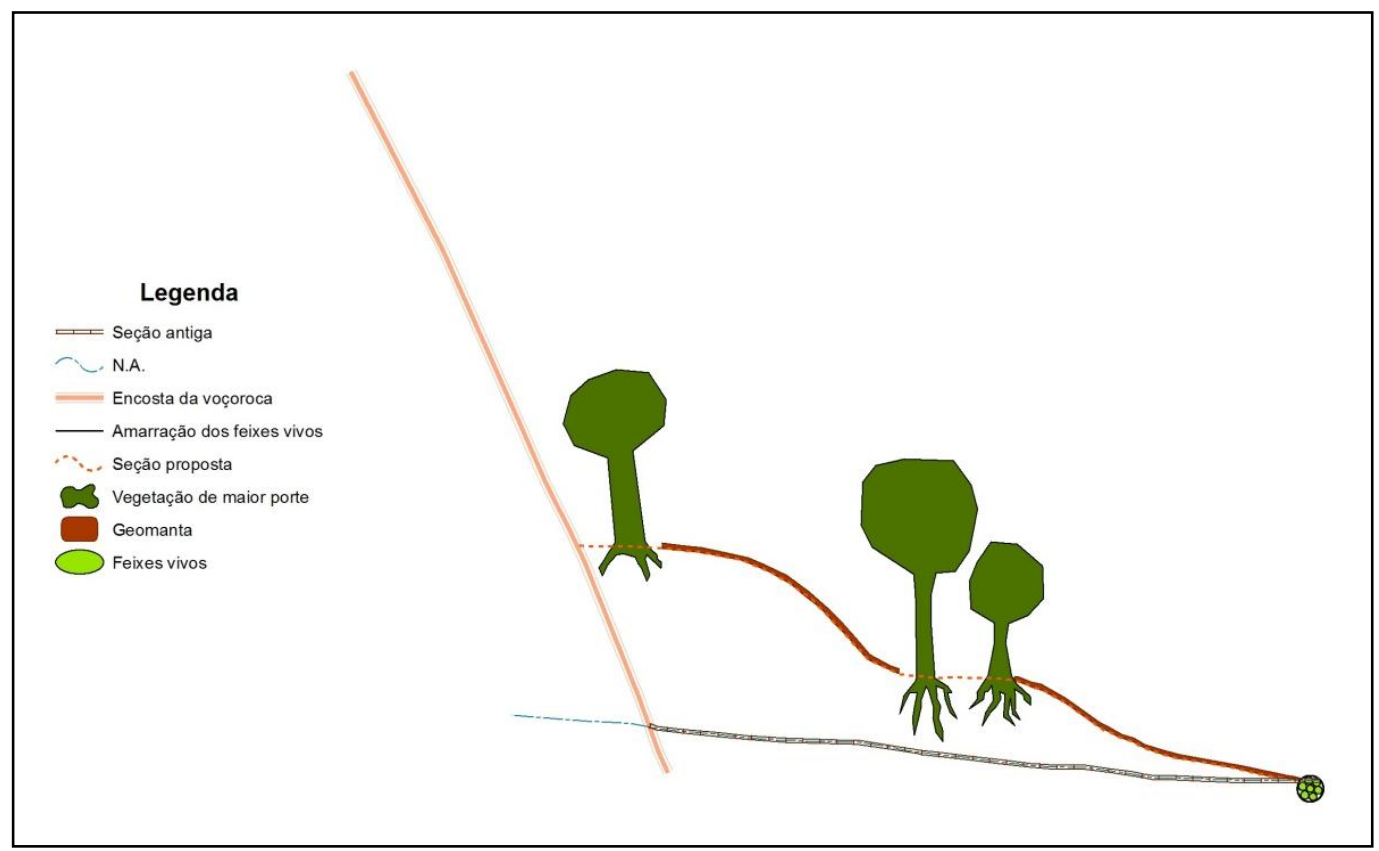

Figura 116 - Seção proposta para a drenagem interna da voçoroca do Córrego do Cravo, Nazareno/MG. 
Ao final, na base da voçoroca, as estruturas podem ser direcionadas para uma área em que se encontra um pequeno curso d'água, indicada na Figura 117.

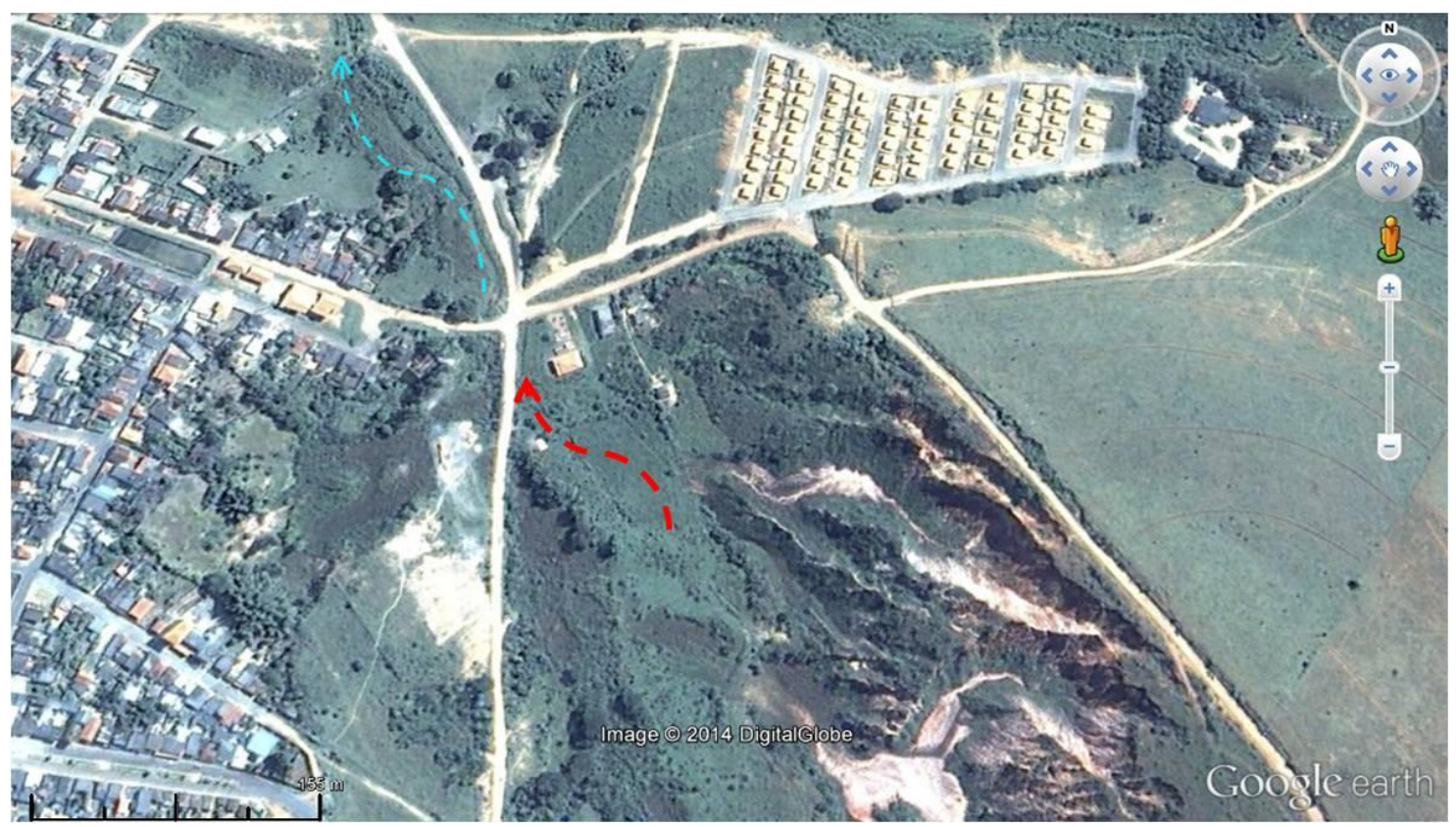

Figura 117 - Destinação dos drenos (seta em vermelho) da água subterrânea da voçoroca do Córrego do Cravo, em Nazareno/MG. Seta em azul, drenagem natural receptora.

A Figura 118 apresenta, aproximadamente, a situação em campo do local apontado na Figura 117.

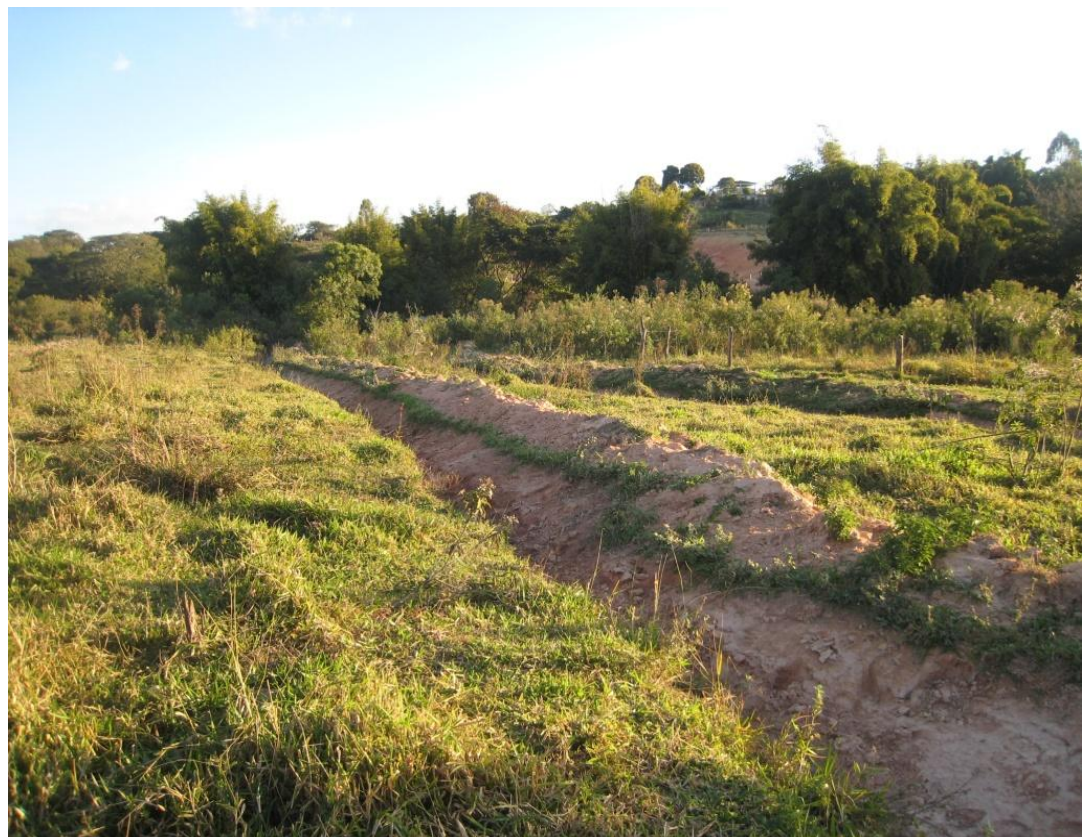

Figura 118 - Área proposta para o término da drenagem no final da base da voçoroca do Córrego do Cravo, em Nazareno/MG. 
É importante atentar para que as residências instaladas na base da voçoroca (próximas à seta vermelha, Figura 117), evitem conectar suas próprias redes de drenagem de água e esgoto no sistema proposto para a voçoroca, para que não ocorra o sobrecarregamento de vazão e a inutilização ou destruição deste sistema. Em adição, salienta-se que o constante monitoramento deve ser realizado com cuidado, percorrendo-se toda a área da voçoroca e todas as estruturas nela instaladas. Além de prevenir quaisquer futuros danos às estruturas, o monitoramento pode direcionar trabalhos de manutenção necessários, como limpeza dos sedimentos, ajustes e replantios, dentre outros, de forma a otimizar este processo e manter a longevidade dos sistemas.

\subsubsection{Proposta Adicional - Estrada de Terra}

Recomenda-se neste capítulo a realização de obra para drenagem da água que escoa da estrada de terra que se encontra lateralmente à voçoroca. Notou-se, em campo, que esta não é realizada de forma efetiva (Figura 119); existe até um ponto (Figura 57) no qual se pode observar o total direcionamento da água escoada da estrada a um dos braços da voçoroca, à jusante, situação a qual se pode concluir que este também é um dos principais fatores que podem estar contribuindo para a continuidade deste processo erosivo. 


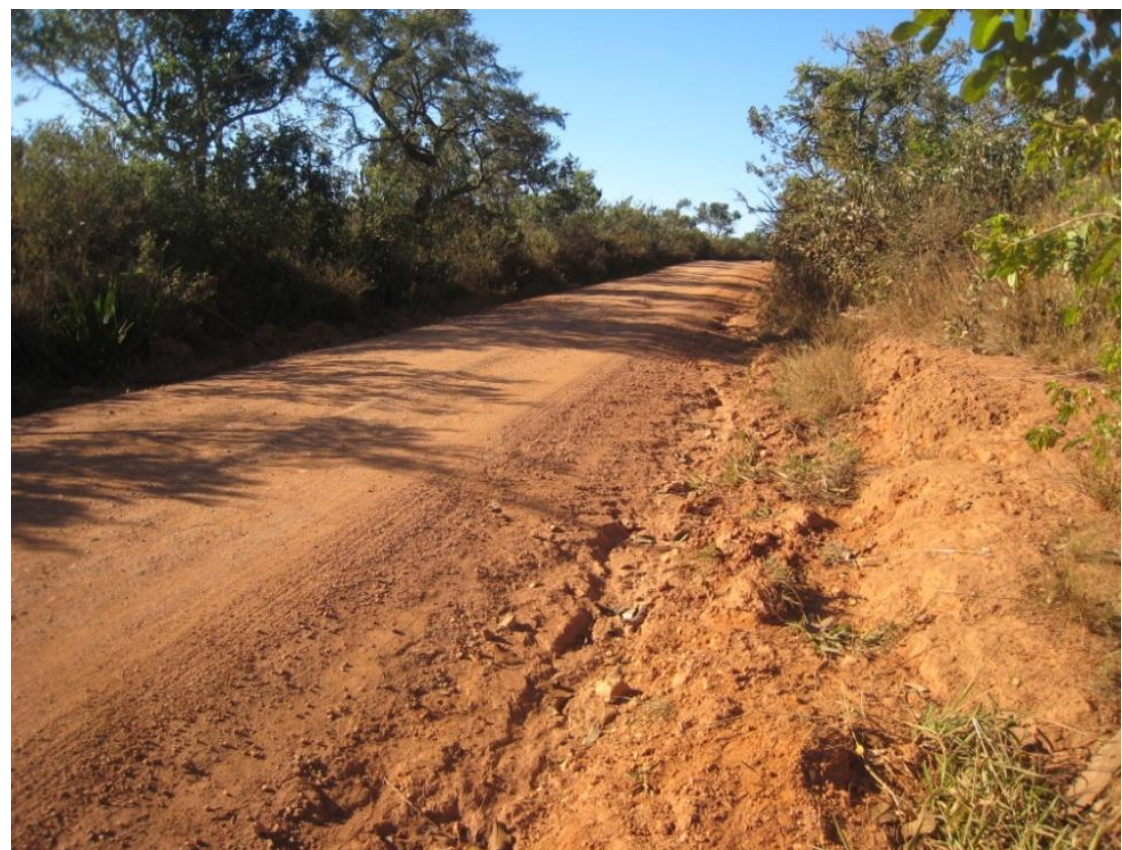

Figura 119 - Estrada de terra limítrofe à lateral da voçoroca do Córrego do Cravo, Nazareno/MG.

Em observação na visita de campo é possível constatar que a distância entre a estrada e os limites da voçoroca não é muito elevada; dessa forma, é recomenda-se como proposta a realização de trincheira de infiltração com acesso direto das águas superficiais nesta estrada de terra.

Como a estrada é bem movimentada, recomenda-se a realização de proteção desta estrutura, como cercas ou semelhante, para evitar que a passagem de veículos sobrecarregue ou destrua a obra. Também é recomendado que seja implantada alguma estrutura de proteção, como geotêxteis, para evitar o crescimento de raízes que possam danificar a trincheira.

\section{CONCLUSÕES}

Partindo-se dos resultados obtidos, tanto nas análises em SIG, quanto nos ensaios em laboratório, é possível concluir que, dos dois tipos principais de solos verificados na área de estudo, o saprolito (proveniente da alteração de granito-gnaisse) é aquele que apresenta maior susceptibilidade aos processos erosivos. A elevada erodibilidade e proporção de silte e areia 
fina em sua composição, os baixos valores de permeabilidade e matéria orgânica, e o elevado grau de alteração que ainda mantém estruturas reliquiares, fazem com que os saprolitos se desestabilizem, tornando-os mais facilmente destacáveis e transportáveis que os Latossolos na voçoroca do Córrego do Cravo. As seções geológicas e as análises em campo indicam claramente que houve e ainda há remoção de material saprolítico na base. Esta remoção é causada pela surgência e oscilação do nível d'água subterrâneo, que provocaram no final da voçoroca fenômenos como pipings e sumidouros, além da desestabilização e movimentação das encostas. Outro fator que condiciona ainda os processos erosivos na área de estudo é a declividade, que apresenta valores predominantes entre 8 e $20 \%$.

No perímetro da voçoroca, a direção de fluxo natural preferencialmente segue para NW e W. Porém, a localização das estradas (perpendicularmente às curvas de nível e nas proximidades da voçoroca, tanto da cabeceira quanto dos braços), concentra o escoamento superficial, elevando-se a velocidade e a energia da água. Além disso, o mapa de uso e ocupação também aponta para a concentração com tendência a direcionar-se para esta área: a estrada de terra na área de cultivo de café, e o próprio cafezal em si, são elementos determinantes para o recolhimento de toda a água na porção mais elevada da bacia de contribuição, conduzindo-se o escoamento em direção à cabeceira da voçoroca do Córrego do Cravo.

As séries históricas de precipitação, apesar de não estarem completas, serviram como base para o maior entendimento da disponibilização da água e da vazão a ser considerada na condução do escoamento superficial. Com isso, foi possível concluir que a melhor concepção de projeto para o disciplinamento da drenagem na voçoroca do Córrego do Cravo deveria necessariamente recolher o escoamento concentrado da área de cultivo de café e direcioná-lo de forma distanciada das bordas da voçoroca, sendo o destino final o córrego existente próximo à área urbana.

Nesse contexto, a estabilização dos processos erosivos na voçoroca do Córrego do Cravo deve abarcar a implantação de obras de drenagem adequadamente projetadas e capazes de direcionar o escoamento superficial para locais menos susceptíveis, já que os fatores condicionantes (susceptibilidade do solo saprolítico e declividade do terreno) combinados com os agentes deflagradores (pluviosidade elevada e intensa, e ocupação e manejo inadequados do solo), acarretam no retorno destes processos na voçoroca. 
As simulações realizadas com o programa Canal auxiliaram o estudo da melhor conformação de condutos livres para direcionamento da água superficial na voçoroca. Com este estudo foi possível concluir que o revestimento, com a finalidade de evitar a exposição dos solos susceptíveis e elevar a rugosidade do canal, e a suavização da inclinação da linha d'água com intervenção no terreno ou ação conjunta dos canais com escadas d'água (representadas pelas barragens) são os meios mais apropriados para a redução do volume, da velocidade e da turbulência no escoamento. Vale ressaltar que o menos indicado, neste caso, seria deixar os canais sem revestimento e com inclinação natural.

A proposta de implantação de trincheiras em conjunto com os canais também tem por finalidade, além da condução, a infiltração da água, principalmente nas áreas em que se tem predomínio de Latossolos. Estes tipos de solos são menos susceptíveis à erosão, apresentando condições favoráveis para este fim, como elevada quantidade de matéria orgânica e permeabilidade, diminuindo-se, assim, o volume de escoamento superficial advindo da cabeceira até a jusante. Também deve ser realizada a condução e infiltração do escoamento concentrado pela estrada de terra que limita lateralmente a voçoroca, para evitar que, mesmo após a implantação de obras de drenagem na bacia de contribuição, os processos erosivos sejam reativados.

Em relação à água subsuperficial, sendo esta o principal condicionante da desestabilização do saprolito na base das encostas, conclui-se que o mais indicado seria manter a evolução em fundo de vale no interior da voçoroca. Isso seria possível com o disciplinamento dos canais já formados, de forma a se reduzir o volume de água disponível nestas áreas em conjunto com a construção dos bancos de sedimentos, porque, através da observação da área interna da voçoroca onde existe estabilidade do nível d'água, verifica-se a ocorrência de sucessão ecológica.

É importante destacar que, dentro das condições de viabilidade financeira e técnicas disponíveis, o cenário ideal para recuperação desta voçoroca seria a utilização de bioengenharia para a construção dos sistemas de drenagem. Ressalta-se, ainda, que qualquer projeto de recuperação de áreas degradadas deve conter um prazo de validade e um cronograma de monitoramento e manutenção, pois as obras são passíveis de perderem o rendimento com o tempo e/ou se deteriorarem. 
Estas propostas podem ser utilizadas para recuperação de voçorocas na região. Entretanto, é fundamental a caracterização das condições e peculiaridades para cada caso, pois a generalização das técnicas de recuperação para qualquer situação pode causar o desperdício de investimentos. Devem-se utilizar as informações com cautela, de forma a integrar as atividades de ocupação humana em equilíbrio com as características de cada ambiente.

\section{RECOMENDAÇÕES}

A concepção do projeto de recuperação da voçoroca do Córrego do Cravo (e de quaisquer outros processos erosivos deste porte) também deve incluir a estabilização dos taludes, com base no detalhamento das características geológicas-geotécnicas da área, além das medidas de drenagem dos escoamentos. A pesquisa desta área já está sendo realizada pela aluna do Departamento de Geotecnia da Escola de Engenharia de São Carlos (Universidade de São Paulo) Maria Paula Pires de Oliveira, sob orientação do professor Dr. Osni José Pejon.

Recomenda-se, ainda, que se entre em contato com o responsável pela propriedade particular em que se encontra o cafezal, localizado à montante da área da voçoroca do Córrego do Cravo, pois nesta propriedade pode ser realizada alguma obra prévia, como bacias de contenção e dissipação, por exemplo, que auxiliariam a elevar a eficiência na redução do escoamento concentrado para a voçoroca.

Além disso, recomenda-se o planejamento em conjunto com a população e os gestores do município em relação a novas funções que possam ser dadas às voçorocas, como parques, por exemplo, de maneira que haja a sensibilização dos indivíduos em relação às dificuldades, soluções e manutenção dos projetos de recuperação de áreas degradadas. 


\section{REFERÊNCIAS BIBLIOGRÁFICAS}

AGASSI, M (Ed.). Soil erosion, conservation and rehabilitation. Marcel Dekker Inc. 1996. $402 \mathrm{p}$

ARAUJO, G. H. S.; ALMEIDA, J. R.; GUERRA, A. J. T. Gestão ambiental de áreas degradadas. Bertrand Brasil, Rio de Janeiro. $7^{\text {a }}$ Ed. 2011. 322p.

ARAUJO, T. P. Estudo do desencadeamento das erosões lineares concentradas em uma área do município de São Pedro/SP. Escola de Engenharia de São Carlos. Universidade de São Paulo (Dissertação de Mestrado). 2011. 181p.

ARAUJO, A. M.; SILVA, A. B. Modelagem de áreas de escoamento superficial a partir do Modelo Digital de Terreno. In: Anais do XV Simpósio Brasileiro de Sensoriamento Remoto - SBSR (INPE). Curitiba. 2011. Pp. 3735 - 3742.

ASSOCIAÇÃO BRASILEIRA DE NORMAS TÉCNICAS (ABNT). (a) NBR 6508: Grãos de solo que passam na peneira de $4,8 \mathrm{~mm}$ - Determinação de massa específica. Rio de Janeiro. 1984. 8p.

(b) NBR 7181: Análise granulométrica. Rio de Janeiro. 1984. 13p.

NBR-10703: Degradação do solo: terminologia. Rio de Janeiro. 1989. 45p.

NBR-13292: Solo-Determinação do coeficiente de permeabilidade de solos granulares à carga constante. Rio de Janeiro. 1995. 8p.

ÁVILA, C.A.; TEIXEIRA, W.; CORDANI, U. G.; BARRUETO, H. R.; PEREIRA, R. M.; MARTINS, V. T. S.; DUNYI, L. The Glória quartz-monzodiorite: isotopic and chemical evidence of arc-related magmatism in the central part of the paleoproterozoic Mineiro belt, Minas Gerais State, Brazil. In: Anais da Academia Brasileira de Ciências. 78 (3). 2006. 543-556p. ISBN: 0001-3765.

BAHIA, V. G.; CURI, N.; CARMO, D. N.; MARQUES, J. J. G. S. M. Fundamentos de erosão do solo (tipos, formas, fatores determinantes e controle). Informe Agropecuário. V. 16, n. 176. Belo Horizonte. 1992. Pp. 25-31.

BAPTISTA, M.; NASCIMENTO, N.; BARRAUD, S. Técnicas compensatórias em drenagem urbana. Associação Brasileira de Recursos Hídricos (ABRH), Porto Alegre. $2^{\mathrm{a}}$ Ed. 2011. 318p.

BARROW, C. J. Land degradation: development and breakdown of terrestrial environments. Cambridge University Press. 1991. 295 p. 
BARROW, C. J. Environmental management for sustainable development. Routledge, Taylor and Francis Group. $2^{\text {nd }}$ Ed. 2006. 454p.

BHATTARAI, R.; KALITA, P. K.; YATSU, S.; HOWARD, H. R.; SVENDSEN, N. G. Evaluation of compost blankets for erosion control from disturbed lands. Journal of Environmental Management, 92. 2011. P. 803-812.

BEASLEY, R. P. Erosion and sediment pollution control. The Iowa State University Press. Iowa. 1972. 320p.

BENSON, C. H.; HARDIANTO, F. S.; MOTAN, E. S. Representative specimen size for hydraulic conductivity assessment of compacted soil liners. In: DANIEL, D. E.; TRAUTWEIN S. J.; (Ed.) Hydraulic conductivity and waste contaminant transport in soil. American Society for Testing and Materials. 1994. P. 3-29.

BERNASCONI, P.; MENDONÇA, R. A. M.; MICOL, L. Uso de SIG no diagnóstico ambiental municipal: estudo de caso no município de Colíder - MT. Anais XIV Simpósio Brasileiro de Sensoriamento Remoto. INPE. 2009. Pp. 3575-3582.

BERTONI, J. C.; TUCCI, C. E. M. Precipitação. In: TUCCI, C. E. M (organizador). Hidrologia: ciência e aplicação. Ed. Universidade/UFRGS: ABRH. $2^{a}$ Ed. 2001. 943p.

BERTONI, J. ; LOMBARDI NETO, F. Conservação do solo. $5^{\text {a }}$ Ed. Editora Ícone, São Paulo. 2005. 355p.

BITAR, O.Y.; BRAGA, T.O. O meio físico na recuperação de áreas degradadas. In: BITAR, O.Y. (Coord.).Curso de geologia aplicada ao meio ambiente. São Paulo: Associação Brasileira de Geologia de Engenharia (ABGE) e Instituto de Pesquisas Tecnológicas (IPT). 1995. Pp.165-179.

BLUM, W. E. H. Basic concepts: degradation, resilience and rehabilitation. In: LAL, R.; BLUM, W. H.; VALENTINE, C.; STEWART, B. A. Eds. Methods for assessment of soil degradation. CRC Press LLC. 1998. 558p.

BOARDMAN, J. Soil erosion science: Reflections on the limitations of current approaches. Catena 68. 2006. Pp. 73-86.

BRANDÃO, S. L.; LIMA, S. C. pH e condutividade elétrica em solução do solo, em áreas de pinus e cerrado na chapada, em Uberlândia (MG). Caminhos de Geografia, Instituto de Geografia (UFU). 3 (6). 2002. P. 46 - 56.

CALDEIRA, T. L.; ARAÚJO, M. M. F.; BESKOW, S. Análise de série hidrológica de precipitação no sul do Rio Grande do Sul para aplicação na gestão e monitoramento de recursos hídricos. In: IV Encontro Sul-brasileiro de Meteorologia. 2011. 8p.

CAMPOS, M. M. R. Utilização de Drenos Horizontais Profundos (DHP) em projetos de recuperação ambiental. Escola Politécnica. Universidade de São Paulo (Dissertação de Mestrado). 2003. 160p mais anexos. 
CARRIJO, B. R.; BACCARO, C. A. D. Análise sobre a erosão hídrica na área urbana de Uberlândia (MG). Caminhos de Geografia 1 (2). 2000. Pp. 70-83.

CASSARO, R. Trabalho de Graduação para conclusão do curso de engenharia ambiental, Escola de Engenharia de São Carlos, da Universidade de São Paulo. 2014. No prelo.

CIVILNET (engenhariacivil.com). Recursos da Engenharia Civil na Internet Nacional. Download de softwares gratuitos para estudo de canais e fluxo. Disponível em: <http://www.engenhariacivil.com/cat/hidraulica_software>. 2014.

CLARK, E. H.; HAVERKAMP, J. A.; CHAPMAN, W. Eroding soils: the off-farm impacts. The Conservation Foundation. Washington, DC. 1985. 252 p.

CHATTOPADHYAY, B. C.; CHAKRAVARTY, S. Application of jute geotextiles as facilitator in drainage. Geotextiles and Geomembranes. 27. 2009. P. 156-161.

CHRISTOFOLETTI, A. Geomorfologia. Ed. Edgard Blucher Ltda. 1974. 149p.

CROBEDDU, E.; BENNIS, S.; RHOUZLANE, S. Improved rational hydrograph method. Journal of Hydrology, 338. 2007. P. 63-72.

CRUZ, R.; SILVA, M. Critério nas estruturas de contenção de processos erosivos. In: $5^{\circ}$ Simpósio sobre Controle de Erosão. ABGE/UNESP. V2. 1995. Pp. 69-71.

DAMÉ, R. C. F.; TEIXEIRA, C. F. A.; TERRA, V. S. S.; ROSSKOFF, J. L. C. Hidrograma de projeto em função da metodologia utilizada na obtenção da precipitação. Revista Brasileira de Engenharia Agrícola e Ambiental. V. 14, n. 1. 2010. P. 46-54.

DANIEL, D. E. State-of-the-art: laboratory hydraulic conductivity tests for saturated soils. In: DANIEL, D. E.; TRAUTWEIN S. J.; (Ed.) Hydraulic conductivity and waste contaminant transport in soil. American Society for Testing and Materials. 1994. P. $30-78$.

DANTAS, A. A. A.; CARVALHO, L. G.; FERREIRA, E. Classificação e tendências climáticas em Lavras, MG. Ciênc. Agrotec., Lavras. v. 31. n. 6. 2007. p. 1862-1866.

DEL GROSSI, S. R. De Uberabinha a Uberlândia: os caminhos da natureza - contribuição ao estudo da geomorfologia urbana. Universidade de São Paulo, Faculdade de Filosofia, Ciências e Letras (Tese de doutorado). 1991. 237p.

DEPARTAMENTO DE ÁGUAS E ENERGIA ELÉTRICA (DAEE); INSTITUTO DE PESQUISAS TECNOLÓGICAS (IPT). Controle de erosão: bases conceituais e técnicas; diretrizes para o planejamento urbano e regional; orientações para o controle de boçorocas urbanas. São Paulo. 1989. 92p. 
DEPARTAMENTO DE ÁGUAS E ENERGIA ELÉTRICA (DAEE). Guia prático para projetos de pequenas obras hidráulicas. Secretaria de Estado de Energia, Recursos Hídricos e Saneamento. São Paulo. 2005. 116p.

DEPARTAMENTO DE HIDRÁULICA E SANEAMENTO (SHS). Programas realizados pelo professor Rodrigo de Melo Porto para utilização em conjunto com seu livro Hidráulica Básica. Escola de Engenaharia de São Carlos, Universidade de São Paulo, São Paulo. Disponível em: <http://www1.eesc.usp.br/shs/index.php/disciplinasengenharia/181-programas-computacionais-para-acompanhamento-do-livroqhidraulica-basicaq>. 2014.

DEPARTAMENTO NACIONAL DE ESTRADAS DE RODAGEM (DNER). ME 228/94: Solos: compactação em equipamento miniatura. Rio de Janeiro, 1994.

ME 256/94: Solos compactados em equipamento miniatura - Perda por imersão. Rio de Janeiro, 1994.

ME 258/94: Solos compactados em equipamento miniatura - Mini MCV. Rio de Janeiro, 1994.

Manual de projeto de obras-de-arte especiais. Ministério dos Transportes, Diretoria de Desenvolvimento Tecnológico. Rio de Janeiro. 1996. 225p.

DIAS, H. C. T.; OLIVEIRA-FILHO, A. T. Fenologia de quatro espécies arbóreas de uma floresta estacional semidecídua montana em Lavras, MG. Revista Cerne, Universidade Federal de Lavras. v.2. n.1. 1996. 20p.

DURLO, M. A.; SUTILI, F. J. Bioengenharia: manejo biotécnico de cursos de água. EST Edições, Porto Alegre. 2005. 189p.

EMPRESA BRASILEIRA DE PESQUISA AGROPECUÁRIA (EMBRAPA). Manual de métodos de análise de solo. Centro Nacional de Pesquisa de Solos, Rio de Janeiro. 1997. 212p.

Práticas mecânicas e vegetativas para controle de voçorocas. Comunicado Técnico, 33. Rio de Janeiro. 2005. 4p.

(a). Avaliação da Aptidão Agrícola das Terras da Zona Campos das Vertentes - MG. Boletim de Pesquisa e Desenvolvimento 91. 2006. ISSN 1678-0892. 62p (incluindo anexos). 
(b). Levantamento de reconhecimento de média intensidade dos solos da Zona Campos das Vertentes - MG. Boletim de Pesquisa e Desenvolvimento 96. Rio de Janeiro. 2006. 326p.

(c). Sistema brasileiro de classificação de solos. $2^{\text {a }}$ Ed. Centro Nacional de Pesquisa de Solos, Rio de Janeiro. 2006. 306p.

Controle dos processos erosivos lineares (ravinas e voçorocas) em áreas de solos arenosos. Circular Técnica 22. Jaguariúna, SP. 2011. 7p.

Sistema Brasileiro de Classificação de Solos. $3^{\text {a }}$ Ed. Brasília, DF. 2013. 353p.

EUSTERHUES, K.; RUMPEL, C.; KÖGEL-KNABNER, I. Stabilization of soil organic matter isolated via oxidative degradation. Organic Geochemistry, 36. 2005. P. 15671575.

EVANGEliStA, A. W. P.; CARVAlHO, L. G.; BERNARDINO, D. T. Caracterização do padrão das chuvas ocorrentes em Lavras, MG. Irriga, v.10, b. 4. 2005. P. 306-317.

FAVIS-MORTLOCK, D. T.; GUERRA, A. J. T. The implications of general circulation model estimates of rainfall for future erosion: a case study from Brazil. Catena, 37. 1999. P. 329-354.

FENDRICH, R. Erosão urbana. In: FENDRICH, R.; OBLADEN, N. L.; AISSE, M. M.; GARCIAS, C. M. Drenagem e controle da erosão urbana. $4^{\mathrm{a}}$ Ed. Champagnat, Curitiba. 1997. 481p.

FENDRICH, R. Chuvas intensas para obras de drenagem (no estado do Paraná). Ed. Champagnat, Curitiba. 1998. 99p.

FERNANDES, L .S; GRIFFITH, J. J.; FONSECA, D. M.; DIAS, L. E.; RUIZ, H. A. Uso de geomantas no controle da erosão superficial hídrica em um talude em corte de estrada. R. Bras. Ci. Solo, 33. 2009. P. 199-206.

FERREIRA, M. D. Análise da evolução dos processos erosivos acelerados em áreas urbanas e das técnicas de controle e recuperação: córrego do Tucum (São Pedro/SP). Universidade de São Paulo, Escola de Engenharia de São Carlos (Dissertação de mestrado). 2004. 172p.

FERREIRA, V. M. Voçorocas no município de Nazareno, MG: origem, uso da terra e atributos do solo. Universidade Federal de Lavras (UFLA) (dissertação de mestrado). Lavras. 2005. 84p.

FERREIRA, R. R. M.; FERREIRA, V. M.; TAVARES FILHO, J.; RALISCH, R. Origem e evolução de voçorocas em cambissolos da bacia Alto Rio Grande, Minas Gerais. In: XXXI Congresso Brasileiro de Ciência do Solo, Gramado-RS. 2007. 5p. 
FERREIRA, R. R. M. Qualidade física de cambissolos sobre dois materiais de origem com pastagens extensivas. Universidade Estadual de Londrina (Tese de doutorado). 2008. $106 p$.

FERREIRA, R. R. M.; FERREIRA, V. M. (Coordenadores). Apostila técnica de estabilização de voçorocas. Projeto Tecendo a Rede Voçorocas, Nazareno - MG. Centro de Regional Integrado de Desenvolvimento Sustentável. 2009. 20p.

FERREIRA, V. M.; SILVA, M. L. N.; CURI, N.; OLIVEIRA, A. H.; SILVA, M. A.; AVANZI, J. C. Influência antrópica e atributos de solo: inter-relações em ambientes de voçorocas na mesorregião Campos das Vertentes, MG. Geografia, Rio claro. V. 36. n. 1. 2011. p. 209-219.

FRANCO, E. J. Dimensionamento de bacias de detenção das águas pluviais com base no Método Racional. Universidade Federal do Paraná (Dissertação de mestrado). 2004. $155 \mathrm{p}$.

FRENZEL, A. Medidas preventivas contra os processos erosivos. IN: Associação Brasileira de Geologia de Engenharia (ABGE). Simpósio sobre o controle de erosão. Curitiba PR. 1980. P. $201-213$.

GIMENES, F. B. Q.; AUGUSTO FILHO, O. Mapas de fragilidade ambiental utilizando o processo de análise hierárquica (AHP) e sistema de informação geográfica (SIG). Anais XVI Simpósio Brasileiro de Sensoriamento Remoto - SBSR. INPE. 2013. Pp. 6564-6571.

GRISSINGER, E. H. (a) Rill and gullies erosion. In: AGASSI, M. (Editor). Soil erosion, conservation and rehabilitation. Marcel Dekker Inc. 1996. 402p.

(b) Reclamation of gullies and channel erosion. In: AGASSI, M. (Editor). Soil erosion, conservation and rehabilitation. Marcel Dekker Inc. 1996. 402p.

GRUPO DE PESQUISA EM RECURSOS HÍDRICOS (GPRH). Universidade de Viçosa, Minas Gerais. Disponível em: <http://www.gprh.ufv.br/>. 2014.

HIGGINS, C. G. Gully development. In: HIGGINS, C. G.; COATES D. R. (Eds.) Groundwater geomorphology: the role of subsurface water in earth-surface processes and landforms. Boulder: Geological Society of America. 1990. Pp. 139-155.

HORTA, I. M. F. Levantamento dos solos e ocupação da superfície do município de Nazareno, MG. Universidade Federal de Lavras (Dissertação de mestrado). 2006. 74p.

HORTA, I. M. F.; PEREIRA, J. A. A.; MARQUES, J. J.; CARVAlHO, L. M. T. Levantamento de reconhecimento com apoio digital dos solos do município de Nazareno-MG. Ciênc. Agrotec., Lavras. v.33. Edição Especial. 2009. P.1940-1947. 
HUDSON, N. Soil Conservation. Iowa State University Press. $3^{a}$ Ed. 1995. 391p.

IDE, D. M. Investigação geotécnica e estudo de um processo erosivo causado por ocupação urbana. Universidade de São Paulo, Escola de Engenharia de São Carlos (dissertação de mestrado). São Carlos. 2009. 129p.

KALINSKI, M. E. Soil Mechanics lab manual. $2^{\text {nd }}$ Ed. John Wiley \& Sons, Inc. 2011. 193p.

KER, J. C. Latossolos do Brasil: uma revisão. Geonomos, v.5 (1). 1997. p.17 - 40.

KNIGHTON, D. Fluvial forms \& processes: a new perspective. Hodder Education, Hachette UK Company. 1998. 383p.

LABORATÓRIO DE EFICIÊNCIA ENERGÉTICA E HIDRÁULICA EM SANEAMENTO (LENHS). Download do software EPA SWMM. Universidade Federal da Paraíba, Paraíba. Disponível em: <http://www.lenhs.ct.ufpb.br/?page_id=1017>. 2014.

LABORATÓRIO DE SISTEMAS DE SUPORTE A DECISÕES EM ENGENHARIA AMBIENTAL E DE RECURSOS HÍDRICOS (LABSID). Download de software $A B C$ 6. Departamento de Engenharia Hidráulica e Sanitária, Escola Politécnica , Universidade de São Paulo, São Paulo. Acesso em: <http://www.labsid.com.br/produto_interna.php?id=92>. 2014.

LACERDA, M. P. C.; QUÉMÉNEUR, J. J. G.; ANDRADE, H.; ALVES, H. M. R.; VIEIRA, T. G. C. Mapeamento preliminar de solos com horizonte B textural e B nítico na região de Lavras, MG. Ciênc. Agrotec., Lavras. v.33, n3. 2009. P. 788-795.

LAFLEN, J. M.; ROOSE, E. J. Methodologies for assessment of soil degradation due to water erosion. In: LAL, R.; BLUM, W. H.; VALENTINE, C.; STEWART, B. A. Eds. Methods for assessment of soil degradation. CRC Press LLC. 1998. 558p.

LAL, R.; BLUM, W. H.; VALENTINE, C.; STEWART, B. A. Eds. Methods for assessment of soil degradation. CRC Press LLC. 1998. 558p.

LAL, R. Soil erosion impact on agronomic productivity and environment quality. Critical Reviewers in Plant Sciences, 17 (4). 1998. P. 319-464.

LAL, R. Soil Degradation by erosion. Land Degradation \& Development, N ${ }^{\circ}$ 12. 2001. 519$539 \mathrm{p}$.

LANNA, A. E. Elementos de estatística e probabilidades. In: TUCCI, C. E. M. (organizador). Hidrologia: ciência e aplicação. $2^{\text {a }}$ Ed. Porto Alegre. Ed. Universidade/UFRGS: ABRH. 2001. 943p.

LEITE, A. L. Migração de íons inorgânicos em alguns solos tropicais, com ênfase nos processos de sorção e difusão molecular. Escola de Engenharia de São Carlos, Universidade de São Paulo (Tese de doutorado). 2001. 254p. 
LUTHIN, J. N. Drainage engineering. Robert E. Krieger Publishing Company. 1973. 250p.

MACHADO, R. As ciências da terra e sua importância para a humanidade - A contribuição brasileira para o Ano Internacional do Planeta Terra - AIPT. $1^{\text {a }}$ edição, Ed. Sociedade Brasileira de Geologia. 2008. 108-126p.

MAGRI, R. A. F. Análise da suscetibilidade à erosão da região do Médio Rio Grande (MG). Escola de Engenharia de São Carlos. Universidade de São Paulo (Dissertação de Mestrado). 2013. 230p.

MALCZEWSKI, J. GIS-based land-use suitability analysis: a critical overview. Progress in Planning, 62. 2004. P. 3-65.

MARQUES NETO, R. As paisagens quartzíticas do planalto do Alto Rio grande: relações entre rocha-relevo-solo-vegetação na Serra de Carrancas (MG). Caminhos de Geografia. Uberlândia. V.13, n.41, 2012. P. 263-281.

MARTINS, J. R. S. Obras de macrodrenagm. In: TUCCI, C. E. M.; PORTO, R. L. L.; BASTOS, M. T. Drenagem Urbana. Editora Universidade Federal do Rio Grande do Sul. 1995. Pp. 167-240.

MELlO, C. R.; SÁ, M. A. C.; CURI, N.; MELlO, J. M.; VIOLA, M. R.; SILVA, A. M. Erosividade mensal e anual da chuva no Estado de Minas Gerais. Pesq. agropec. bras. V.42, n.4. 2007. P.537-545.

MENEZES, M. D.; CURI, N.; MARQUES, J. J.; MELlO, C. R.; ARAÚJO, A. R. Levantamento pedológico e sistema de informações geográficas na avaliação do uso de terras em sub-bacia hidrográfica de Minas Gerais. Ciênc. Agrotec., Lavras. V.33, n.6. 2009. P.1544-1553.

MICHELIN, R. G. Drenagem superficial e subterrânea de estradas. (2a ed.) Multilibri. Porto Alegre. 1975. 274 p.

MORAIS, F.; BACELlAR, L. A. P.; SOBREIRA, F. G. Análise da erodibilidade de saprolitos de gnaisse. R. Bras. Ci. Solo, 28. 2005. p. 1055-1062.

MORGAN, R. P. C. Soil erosion and its control. $2^{\mathrm{a}}$ ed. Longman. Nova York. 1995. 198p.

MORGAN, R. P. C. Soil erosion and conservation. $3^{\text {a }}$ ed. Blackwell Publishing. 2005. 304p.

NOGAMI, J. S.; VILLIBOR, D. F. Pavimentação de baixo custo com solos lateríticos. Ed. Vilibor. 1995. 240p.

NUNES, L. C. Geocronologia, geoquímica isotópica e litoquímica do plutonismo dioríticogranítico entre Lavras e Conselheiro Lafaiete: implicações para a evolução Paleoproterozóica da parte central do Cinturão Mineiro. Instituto de Geociências. Universidade de São Paulo (Dissertação de Mestrado). 2007. 96p (incluindo anexo). 
OLIVEIRA, A. L. Drenagem subsuperficial de pavimentos flexíveis. Escola Politécnica. Universidade de São Paulo (Dissertação de Mestrado). 1982. 157p.

OLIVEIRA, L. F. C.; FIOREZE, A. P.; MEDEIROS, A. M. M.; SILVA, M. A. S. Comparação de metodologias de preenchimento de falhas de séries históricas de precipitação pluvial anual. R. Bras. Eng. Agríc. Ambiental, v.14, n.11. 2010. p.11861192.

OLIVEIRA, M. P. P. Dissertação de Mestrado para obtenção de título de Mestre em Ciências, Programa de Pós-Graduação em Geotenica, Escola de Engenharia de São Carlos, da Universidade de São Paulo. .... No prelo.

OLIVEIRA, M. P. P.; SAMPAIO, L. F.; RODRIGUES, V. G. S.; FERREIRA, V. M.; PEJON, O. J. Caracterização preliminar da boçoroca do Córrego do Cravo, Nazareno/MG - Brasil. In: VII Congreso Uruguayo de Geología. 2013. P. 96-100.

PEREIRA, R. M.; ÁVILA, C. A. Distribuição e aspectos metalogenéticos das corrências de scheelita no Pré-Cambriano do estado de Minas Gerais, Brasil. Geonomos, 4 (2): 69 80. 1996.

PEREIRA, R. M.; ÁVILA, C. A.; NEUMANN, R. Estudo mineralógico e químico da cassiterita e de suas inclusões sólidas: implicações com a paragênese das mineralizações da província pegmatítica de São João del Rei, Minas Gerais, Brasil. Arquivos do Museu Nacional, Rio de Janeiro. V. 62, n. 3. 2004. p. 321-336. ISSN: 0365-4508.

PEDRO, F. G.; LORANDI, R. Potencial natural de erosão na área periurbana de São CarlosSP. Revista Brasileira de Cartografia, No 56/01. 2004. Pp. 28-33.

PEJON, O. J. Mapeamento geotécnico da folha de Piracicaba-SP (escala 1:100.000): estudo de aspectos metodológicos, de caracterização e de apresentação dos atributos. Escola de Engenharia de São Carlos. Universidade de São Paulo (Tese de Doutorado). 1992. $2 \mathrm{v}$.

PETERSEN, G. W.; NIZEYIMANA, E.; EVANS, B. M. Applications of Geographic Information System in soil degradation assessments. In: LAL, R.; BLUM, W. H.; VALENTINE, C.; STEWART, B. A. Eds. Methods for assessment of soil degradation. CRC Press LLC. 1998. 558p.

PIMENTEL, D.; ALLEN, J.; BEERS, A.; GUINAND, L.; LINDER, R.; McLAUGHLIN, P.; MEER, B.; MUSONDA, D.; PERDUE, D.; POISSON, S.; SIEBERT, S.; STONER, K.; SALAZAR, R.; HAWKINS, A. World agriculture and soil erosion. BioScience. Vol. 37, No. 4, Apr., 1987. Pp. 277-283.

PONTES, A. B. Controle da erosão em áreas urbanas. IN: Associação Brasileira de Geologia de Engenharia (ABGE). Simpósio sobre o controle de erosão. Curitiba - PR. 1980. P. $37-83$. 
PONS, N. A. D. Levantamento e diagnóstico geológico-geotécnico de áreas degradadas na cidade de São Carlos - SP, com auxílio de geoprocessamento. V.1. Universidade de São Paulo, Escola de Engenharia de São Carlos. (Tese de doutorado). 2006. 195 p.

PORTO, R. M. Hidráulica básica. 4ª Ed. Publicação Escola de Engenharia de São Carlos (EESC - USP). Projeto REENGE. 2006. 519p.

RODRIGUES, J. E. Estudo de fenômenos erosivos acelerados - boçorocas. Universidade de São Paulo, Escola de Engenharia de São Carlos (Tese de Doutorado). São Carlos. 1982. 162p.

RODRIGUES, A. C. P. Rochas metamórficas máficas e ultramáficas do Greenstone Belt Barbacena, na região de Itutinga, MG. Instituto de Geociências. Universidade Estadual de Campinas (Dissertação de Mestrado). 2000. 121p.

RODRIGUES, S. C.; BEZERRA, J. F. R. Study of matric potential and geotextiles applied to degraded soil recovery, Uberlândia (MG), Brazil. Environmental Earth Science, 60. 2010. P. 1281-1289.

ROTTA, C. M. S. Estudo da recuperação de áreas degradadas por processos erosivos: procedimentos e eficiência dos métodos. Universidade de São Paulo, Escola de Engenharia de São Carlos (Dissertação de Mestrado). São Carlos. 2012. 166p.

ROTTA, C. M. S.; ZUQUETTE, L. V. Erosion feature reclamation in urban areas: typical unsuccessful examples from Brazil. Environmental Earth Sciences. 2013. 21p.

SALOMÃO, F. X. T; IWASA, O. Y. Erosão e ocupação rural e urbana. In: BITAR, O. Y. Curso de geologia aplicada ao meio ambiente. Associação Brasileira de Geologia de Engenharia (ABGE). São Paulo. 1995. Pp. 31-57.

SAMPAIO, L. F.; OLIVEIRA, M. P. P.; GIMENES, F. B. Q.; RODRIGUES, V. G. S.; PEJON, O. J. Utilização de SIG e índices morfométricos para estudo dos processos erosivos em uma bacia do município de Nazareno/MG. In: $14^{\circ}$ Congresso Brasileiro de Geologia de Engenharia e Ambiental, Anais... 2013. 9p.

SAMPAIO, L. F.; OLIVEIRA, M. P. P.; RODRIGUES, V. G. S.; PEJON, O. J. Review of soil degradation in the region of Nazareno, MG-Brazil. In: XII IAEG Congress Torino. 2014. 6p. (no prelo).

SÁNCHEZ, L. H. Avaliação de impacto ambiental: conceitos e métodos. Oficina de Textos. São Paulo. 2006. 495p.

SEN, Z. Applied hydrogeology for scientists and engineers. CRC Press Inc. 1995. 444p. 
SHI, Z-H; CHEN, L-D.; FANG, N-F.; QIN, D-F.; CAI, C-F. Research on the SCS-CN initial abstraction ratio using rainfall-runoff event analysis in the Three Gorges Area, China. Catena 77. 2009. P.1-7

SILVA, A. C. Relação entre voçorocas e solos na região de Lavras (MG). Escola Superior de Agricultura de Lavras (Dissertação de mestrado). 1990. 125p.

SILVA, A. M.; SCHULZ, H. E.; CAMARGO, P. B. Erosão e hidrossedimentologia em bacias hidrográficas.Ed. RiMa. 2004. 140p.

SILVA, P. M. O. Modelagem do escoamento superficial e da erosão hídrica na sub-bacia hidrográfica do ribeirão Marcela, Alto Rio Grande, MG. Universidade Federal de Lavras (Tese de Doutorado). 2006. 155p.

SILVEIRA, G. M. Análise de sensibilidade de hidrogramas de projeto aos parâmetros de sua definição indireta. Escola Politécnica, Universidade de São Paulo (Dissertação). 2010. $243 p$.

SIMÃO JUNIOR, R. Uso do SIG como ferramenta de auxílio na recuperação de áreas degradadas. Escola de Engenharia de São Carlos, Universidade de São Paulo (Dissertação de mestrado). 2001. 92p.

SOUZA, M. L. Proposta de um sistema de classificação de feições erosivas voltados a estudos de procedimentos de análises de decisões quanto a medidas corretivas, mitigadoras e preventivas: aplicação no município de Umuarama (PR). Instituto de Geociências. Universidade Estadual Paulista (Tese de Doutorado). Rio Claro. 2001. 284p.

SOIL AND WATER ASSESSMENT TOOL (SWAT). United States Department of Agriculture - Agricultural Research Service em conjunto com Texas A\&M AgriLife Research. Disponível para download em <http://swat.tamu.edu/>. Acesso em 03 de março de 2014.

STONE, J.; RENARD, K. G.; LANE, L. J. Runoff estimation on agricultural fields. In: AGASSI, M. (Editor). Soil erosion, conservation and rehabilitation. Marcel Dekker Inc. 1996. 402p.

TEIXEIRA, W.; FIGUEIREDO, M. C. H. An outline of Early Proterozoic crustal evolution in the São Francisco craton, Brazil: a review. Precambrian Research, 53. 1991. p. 1-22.

TEIXEIRA, W.; ÁVILA, C. A.; NUNES, L. C. Nd-Sr Isotopic Geochemistry and U-Pb Geochronology of the Fé granitic gneiss and Lajedo granodiorite: Implications for Paleoproterozoic Evolution of the Mineiro Belt, southern São Francisco Craton, Brazil. Geol. USP Sér. Cient., São Paulo. v. 8. n. 1. 2008. P. 53-74.

TOLEDO, C. L. B. Evolução geológica das rochas máficas e ultramáficas no Greenstone Belt Barbacena, região de Nazareno, MG. Instituto de Geociências. Universidade Estadual de Campinas. Tese de Doutorado. 2002. 297p. 
THOMPSON, D. B. The Rational Method, regional regression equations, and site-specific flood frequency relations. Texas Department of Transportation. 2006. Disponível em <http://www.depts.ttu.edu/techmrtweb/Reports/Complete\%20Reports/4405-1.pdf $>$.

Acesso em 27 de janeiro de 2013.

TUCCI, C. E. M. (organizador). Hidrologia: ciência e aplicação. Ed. Universidade/UFRGS: ABRH. $2^{\text {a }}$ Ed. 2001. 943p.

VALENTE, W. Dimensionamento da drenagem subsuperficial. Escola Politécnica. Universidade de São Paulo (Tese de Doutorado). 1988. 254p.

VASQUES, F. S. G. Mapeamento geológico de rochas metamáficas e metassedimentares do Greenstone Belt Rio das Mortes na região de São Tiago - Cassiterita e estudo petrográfico e geoquímico de diques metabásicos e de diabásio. Instituto de Agronomia. Universidade Federal Rural do Rio de Janeiro (Monografia de Graduação). 2007. 64p (incluindo mapa em anexo).

WARFORD, J. J. Natural resources and economic policy in developing countries. The Annals of Regional Science. Vol. 21 (3). 1987. Pp. 3-17.

WATER EROSION PREDICTION PROJECT (WEPP). United States Department of Agriculture - Agricultural Research Service. Disponível para download em <http://www.ars.usda.gov/Research/docs.htm?docid=10621>. Acesso em 03 de março de 2014.

WILKEN, P. S. Engenharia de drenagem superficial. Companhia de Tecnologia de Saneamento Ambiental (CESTESB). São Paulo. 1978. 477p.

YAMANOUTH, G. R. B. Avaliação dos processos erosivos e das técnicas de controle e reabilitação - bacia do córrego do Espraiado (São Pedro - SP). Escola de Engenharia de São Carlos, Universidade de São Paulo (Dissertação de mestrado). V. 1. 2003. $177 \mathrm{p}$.

ZACHAR, D. Soil erosion (Development in Soil Science 10). Forest Research Institute, Zvolen. Tchecoslováquia. 1982. 548p.

ZUAZO, V. H. D.; PLEGUEZUELO, C. R. R. Soil-erosion and runoff prevention by plant covers. A review. Agron. Sustain. Dev. 28. 2008. P. 65-86. 
ANEXOS 


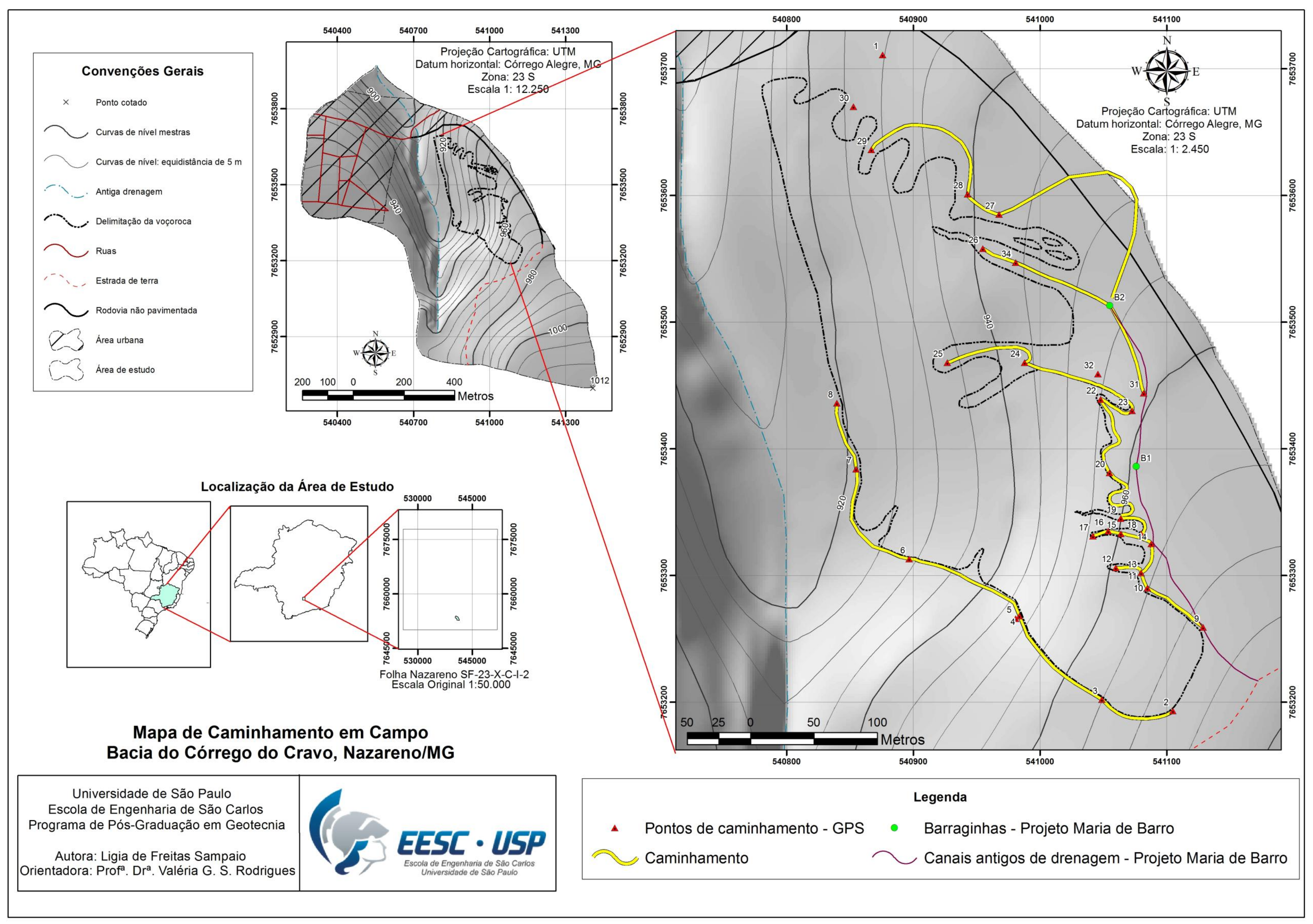

Anexo 01 - Mapa de caminhamento em campo. Voçoroca do Córrego do Cravo, Nazareno (MG). 


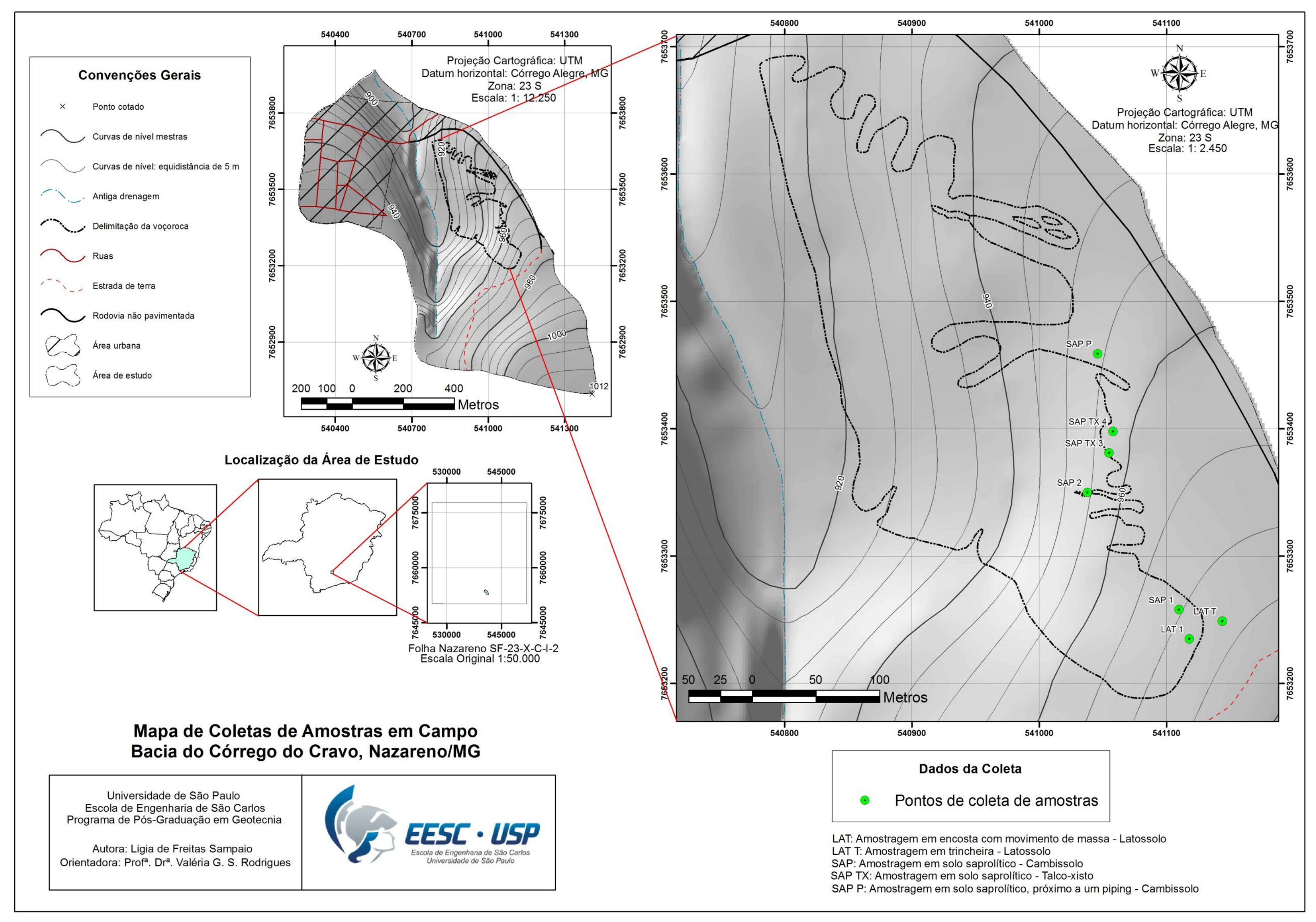

Anexo 02 - Mapa de coletas de amostras em campo. Voçoroca do Córrego do Cravo, Nazareno (MG). 


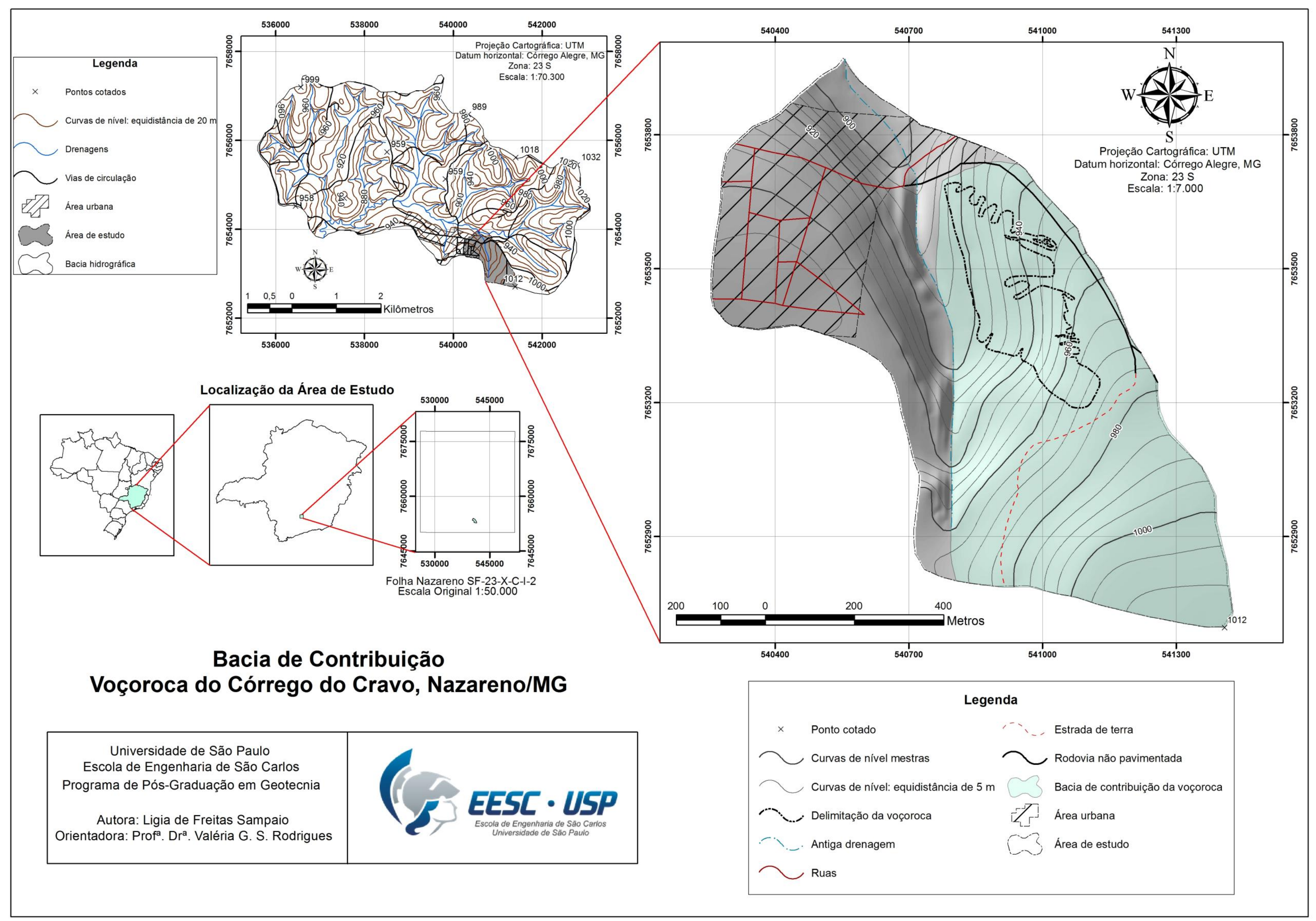

Anexo 03 - Bacia de Contribuição. Voçoroca do Córrego do Cravo, Nazareno (MG) 


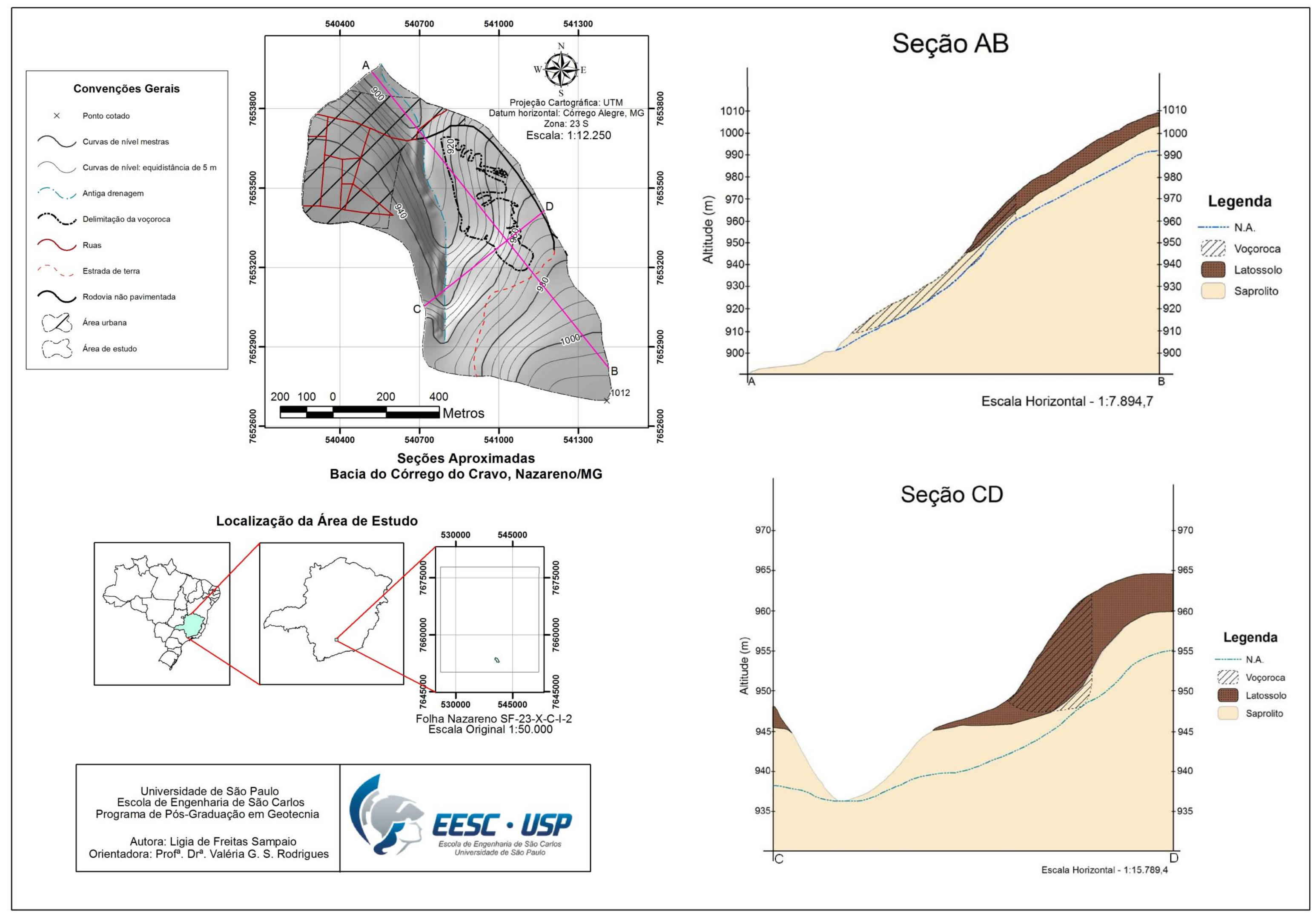

Anexo 04 - Seções aproximadas. Bacia de Córrego do Cravo, Nazareno (MG) 